\title{
eCommons@AKU
}

Woman and Child Health

Division of Woman and Child Health

December 2010

\section{Vitamin A supplementation for preventing morbidity and mortality in children from 6 months to 5 years of age}

Aamer Imdad

Aga Khan University

Kurt Herzer

Evan Mayo-Wilson

Mohammad Yawar Yakoob

Zulfiqar Ahmed Bhutta

Aga Khan University, zulfiqar.bhutta@aku.edu

Follow this and additional works at: https://ecommons.aku.edu/

pakistan_fhs_mc_women_childhealth_wc

Part of the Pediatrics Commons

\section{Recommended Citation}

Imdad, A., Herzer, K., Mayo-Wilson, E., Yakoob, M., Bhutta, Z. A. (2010). Vitamin A supplementation for preventing morbidity and mortality in children from 6 months to 5 years of age. Cochrane Database of Systematic Reviews(12), 8524.

Available at: https://ecommons.aku.edu/pakistan_fhs_mc_women_childhealth_wc/86 


\section{(E) Cochrane Library}

Cochrane Database of Systematic Reviews

\section{Vitamin A supplementation for preventing morbidity and mortality in children from 6 months to 5 years of age (Review)}

Imdad A, Herzer K, Mayo-Wilson E, Yakoob MY, Bhutta ZA

Imdad A, Herzer K, Mayo-Wilson E, Yakoob MY, Bhutta ZA.

Vitamin A supplementation for preventing morbidity and mortality in children from 6 months to 5 years of age.

Cochrane Database of Systematic Reviews 2010, Issue 12. Art. No.: CD008524.

DOI: 10.1002/14651858.CD008524.pub2.

www.cochranelibrary.com

Vitamin A supplementation for preventing morbidity and mortality in children from 6 months to 5 years of age (Review) Copyright $\odot 2011$ The Cochrane Collaboration. Published by John Wiley \& Sons, Ltd. 
TABLE OF CONTENTS

HEADER . . . . . . . . . . . . . . . . . . . . . . . . . . . . . . . . . . . . . . . . . . . . . . . . . . . . . . .

ABSTRACT . . . . . . . . . . . . . . . . . . . . . . . . . . . . . . . . . . . . . . . . . . . . . . . . . .

PLAIN LANGUAGE SUMMARY . . . . . . . . . . . . . . . . . . . . . . . . . . . . . . . . . . . . . . . . . . . . .

SUMMARY OF FINDINGS FOR THE MAIN COMPARISON . . . . . . . . . . . . . . . . . . . . . . . . . . . . 3

BACKGROUND . . . . . . . . . . . . . . . . . . . . . . . . . . . . . . . . . . . . . . . . . . 9

OBJECTIVES . . . . . . . . . . . . . . . . . . . . . . . . . . . . . . . . . . . . . . . . . . . . . . . .

METHODS . . . . . . . . . . . . . . . . . . . . . . . . . . . . . . . . . . . . . . . . .

RESUlTS . . . . . . . . . . . . . . . . . . . . . . . . . . . . . . . . . . . . . . . . . . . . . . . .

Figure 1. . . . . . . . . . . . . . . . . . . . . . . . . . . . . . . . . . . . . . . . . . 14

Figure 2. . . . . . . . . . . . . . . . . . . . . . . . . . . . . . . . . . . . . . 16

Figure 3. . . . . . . . . . . . . . . . . . . . . . . . . . . . . . . . . . . . . . 18

Figure 4. . . . . . . . . . . . . . . . . . . . . . . . . . . . . . . . . . . . . . 20

Figure 5. . . . . . . . . . . . . . . . . . . . . . . . . . . . . . . . 20

Figure 6. . . . . . . . . . . . . . . . . . . . . . . . . . . . . . . . . . . . . . $\quad .21$

Figure $7 . \quad$. . . . . . . . . . . . . . . . . . . . . . . . . . . . . . . . . . . . . $\quad 22$

DISCUSSION . . . . . . . . . . . . . . . . . . . . . . . . . . . . . . . . . . . . . . . . . .

AUTHORS' CONCLUSIONS . . . . . . . . . . . . . . . . . . . . . . . . . . . . . . . . . . . .

ACKNOWLEDGEMENTS . . . . . . . . . . . . . . . . . . . . . . . . . . . . . . . . . . . . . . . . . . . . .

REFERENCES . . . . . . . . . . . . . . . . . . . . . . . . . . . . . . . . . . . . . . . . . . . . . . .

CHARACTERISTICS OF STUDIES . . . . . . . . . . . . . . . . . . . . . . . . . . . . . . . . . . . . . .

DATA AND ANALYSES . . . . . . . . . . . . . . . . . . . . . . . . . . . . . . . . . . . . . . . . . . . . . . . . . . .

Analysis 1.1. Comparison 1 Vitamin A versus Control, Outcome 1 Mortality (all-cause) at Longest Follow-up. $\quad$. 99 99

Analysis 1.2. Comparison 1 Vitamin A versus Control, Outcome 2 Mortality (all-cause) at Longest Follow-up (by Age). 100

Analysis 1.3. Comparison 1 Vitamin A versus Control, Outcome 3 Mortality (all-cause) at Longest Follow-up (by Sex). 101

Analysis 1.4. Comparison 1 Vitamin A versus Control, Outcome 4 Mortality (all-cause) at Longest Follow-up (Sensitivity

Analysis including DEVTA trial). . . . . . . . . . . . . . . . . . . . . . . . . . . . . . . . . . . . $\quad 102$

Analysis 1.5. Comparison 1 Vitamin A versus Control, Outcome 5 Mortality due to Diarrhoea at Longest Follow-up. 104

Analysis 1.6. Comparison 1 Vitamin A versus Control, Outcome 6 Mortality due to Measles at Longest Follow-up. . 105

Analysis 1.7. Comparison 1 Vitamin A versus Control, Outcome 7 Mortality due to Meningitis at Longest Follow-up. 106

Analysis 1.8. Comparison 1 Vitamin A versus Control, Outcome 8 Mortality due to LRTI at Longest Follow-up. . . 107

Analysis 1.9. Comparison 1 Vitamin A versus Control, Outcome 9 Diarrhoea Incidence at Longest Follow-up. $\quad$. $\quad 108$

Analysis 1.10. Comparison 1 Vitamin A versus Control, Outcome 10 Diarrhoea Prevalence at Longest Follow-up. . 109

Analysis 1.11. Comparison 1 Vitamin A versus Control, Outcome 11 Measles Incidence at Longest Follow-up. $\quad$. 110

Analysis 1.12. Comparison 1 Vitamin A versus Control, Outcome 12 Malaria Incidence at Longest Follow-up. $\quad$. $\quad 111$

Analysis 1.13. Comparison 1 Vitamin A versus Control, Outcome 13 Malaria Prevalence at Longest Follow-up. $\quad$. $\quad 111$

Analysis 1.14. Comparison 1 Vitamin A versus Control, Outcome 14 Lower Respiratory Tract Infection Incidence at

Longest Follow-up. . . . . . . . . . . . . . . . . . . . . . . . . . . . . . . . .

Analysis 1.15. Comparison 1 Vitamin A versus Control, Outcome 15 Bitot's Spots Prevalence at Longest Follow-up.

Analysis 1.16. Comparison 1 Vitamin A versus Control, Outcome 16 Night Blindness Incidence at Longest Follow-up.

Analysis 1.17. Comparison 1 Vitamin A versus Control, Outcome 17 Night Blindness Prevalence at Longest Follow-up.

Analysis 1.18. Comparison 1 Vitamin A versus Control, Outcome 18 Xerophthalmia Incidence at Longest Follow-up.

Analysis 1.19. Comparison 1 Vitamin A versus Control, Outcome 19 Xerophthalmia Prevalence at Longest Follow-up.

Analysis 1.20. Comparison 1 Vitamin A versus Control, Outcome 20 Vitamin A Deficient at Longest Follow-up.

Analysis 1.21. Comparison 1 Vitamin A versus Control, Outcome 21 Vitamin A Serum Level at Longest Follow-up.

Analysis 1.22. Comparison 1 Vitamin A versus Control, Outcome 22 Hospitalisation, Number of Children Hospitalised

Once or More at Longest Follow-up. . . . . . . . . . . . . . . . . . . . . . . . . . . . . . .

Analysis 1.23. Comparison 1 Vitamin A versus Control, Outcome 23 Hospitalisation due to Diarrhoea at Longest Follow-

up. . . . . . . . . . . . . . . . . . . . . . . . . . . . . . . . . . . . . . . .

Analysis 1.24. Comparison 1 Vitamin A versus Control, Outcome 24 Hospitalisation due to Lower Respiratory Tract

Infection at Longest Follow-up. . . . . . . . . . . . . . . . . . . . . . . . . . . . . . . . . . . . .

Analysis 1.25. Comparison 1 Vitamin A versus Control, Outcome 25 Side effect - Bulging Fontanelle. 
Analysis 1.26. Comparison 1 Vitamin A versus Control, Outcome 26 Side effect - Vomiting. . . . . . . . . . . 120

ADDITIONAL TABLES . . . . . . . . . . . . . . . . . . . . . . . . . . . . . . . . . . . 120

APPENDICES . . . . . . . . . . . . . . . . . . . . . . . . . . . . . . . . . . . . . 123

WHAT'S NEW . . . . . . . . . . . . . . . . . . . . . . . . . . . . . . . . . . . . . . . 125

CONTRIBUTIONS OF AUTHORS . . . . . . . . . . . . . . . . . . . . . . . . . . . . . . . . . . . . . . . . . . . .

DECLARATIONS OF INTEREST . . . . . . . . . . . . . . . . . . . . . . . . . . . . . . . . . . . . 125

SOURCES OF SUPPORT . . . . . . . . . . . . . . . . . . . . . . . . . . . . . . . . . . . . . . . . . . . . . . . .

DIFFERENCES BETWEEN PROTOCOL AND REVIEW . . . . . . . . . . . . . . . . . . . . . . . . . . 126

INDEX TERMS . . . . . . . . . . . . . . . . . . . . . . . . . . . . . . . . . . . . . . . . . . . 126 


\title{
[Intervention Review]
}

\section{Vitamin A supplementation for preventing morbidity and mortality in children from 6 months to 5 years of age}

\author{
Aamer Imdad ${ }^{1}$, Kurt Herzer ${ }^{2}$, Evan Mayo-Wilson ${ }^{3}$, Mohammad Yawar Yakoob ${ }^{1}$, Zulfiqar A Bhutta ${ }^{1}$ \\ ${ }^{1}$ Division of Women and Child Health, Aga Khan University Hospital, Karachi, Pakistan. ${ }^{2}$ Johns Hopkins School of Medicine, \\ Baltimore, MD, USA. ${ }^{3}$ The Centre for Evidence-Based Intervention, University of Oxford, Oxford, UK \\ Contact address: Zulfiqar A Bhutta, Division of Women and Child Health, Aga Khan University Hospital, Stadium Road, PO Box \\ 3500, Karachi, 74800, Pakistan. zulfiqar.bhutta@aku.edu.
}

Editorial group: Cochrane Developmental, Psychosocial and Learning Problems Group.

Publication status and date: Edited (no change to conclusions), published in Issue 1, 2011.

Review content assessed as up-to-date: 26 October 2010.

Citation: Imdad A, Herzer K, Mayo-Wilson E, Yakoob MY, Bhutta ZA. Vitamin A supplementation for preventing morbidity and mortality in children from 6 months to 5 years of age. Cochrane Database of Systematic Reviews 2010, Issue 12. Art. No.: CD008524. DOI: 10.1002/14651858.CD008524.pub2.

Copyright (C) 2011 The Cochrane Collaboration. Published by John Wiley \& Sons, Ltd.

\section{A B S T R A C T}

\section{Background}

Vitamin A deficiency (VAD) is a major public health problem in low and middle income countries affecting 190 million children under 5. VAD can lead to many adverse health consequences, including death.

\section{Objectives}

To evaluate the effect of vitamin A supplementation (VAS) for preventing morbidity and mortality in children aged 6 months to 5 years.

\section{Search methods}

We searched CENTRAL (The Cochrane Library 2010, Issue 2), MEDLINE (1950 to April Week 2 2010), EMBASE (1980 to 2010 Week 16), Global Health (1973 to March 2010), Latin American and Caribbean Health Sciences (LILACS), metaRegister of Controlled Trials and African Index Medicus (27 April 2010).

\section{Selection criteria}

Randomised controlled trials (RCTs) and cluster RCTs evaluating the effect of synthetic VAS in children aged 6 months to 5 years living in the community. We excluded studies of children in hospital and children with disease or infection. We excluded studies evaluating the effects of food fortification, consumption of vitamin A rich foods or beta-carotene supplementation.

\section{Data collection and analysis}

Two authors independently assessed studies for inclusion. Data were double abstracted and discrepancies resolved by discussion. Metaanalyses were performed for outcomes including all-cause and cause-specific mortality, disease, vision, and side-effects.

\section{Main results}

Forty-three trials involving 215,633 children were included. A meta-analysis for all-cause mortality included 17 trials (194,795 children). At follow-up, there was a $24 \%$ observed reduction in the risk of all-cause mortality for vitamin A compared with control (Relative risk $(\mathrm{RR})=0.76(95 \%$ confidence interval (CI) 0.69 to 0.83$)$. Seven trials reported diarrhoea mortality and showed a $28 \%$ overall reduction 
for VAS ( $R R=0.72$ (95\% CI 0.57 to 0.91$)$ ). There was no significant effect of VAS on cause specific mortality of measles, respiratory disease and meningitis. VAS reduced incidence of diarrhoea $(\mathrm{RR}=0.85$ (95\% CI 0.82 to 0.87$)$ ) and measles morbidity (RR $=0.50$ (95\% CI 0.37 to 0.67$)$ ); however, there was no significant effect on incidence of respiratory disease or hospitalisations due to diarrhoea or pneumonia. There was an increased risk of vomiting within the first 48 hours of VAS (RR $=2.75$ (95\% CI 1.81 to 4.19 )).

\section{Authors' conclusions}

VAS is effective in reducing all-cause mortality and we recommend universal supplementation for children under 5 in areas at risk of VAD. Further placebo-controlled trials of VAS in children between 6 months and 5 years of age are unnecessary, although studies that compare different doses and delivery mechanisms are needed.

\section{PLAIN LANGUAGE SUMMARY}

\section{Vitamin A supplementation for preventing disease and death in children 6 months to five years of age}

Vitamin A deficiency (VAD) is a major public health problem in low and middle income countries affecting 190 million children under 5 years of age. VAD pre-disposes children to increased risk of a range of problems, including respiratory diseases, diarrhoea, measles and vision problems, and can lead to death.

This review, including 43 randomised trials representing 215,633 children, shows that giving vitamin A capsules to children aged 6 months to 5 years can reduce death and some diseases. The results of 17 of the studies were summarised and indicate that vitamin $\mathrm{A}$ reduces the overall risk of death by $24 \%$. Death due to measles, respiratory infections or meningitis was not specifically reduced, but vitamin A can reduce new occurrences of diarrhoea and measles. When people take very large doses of vitamin A, they may be more likely to vomit within two days of taking it. 


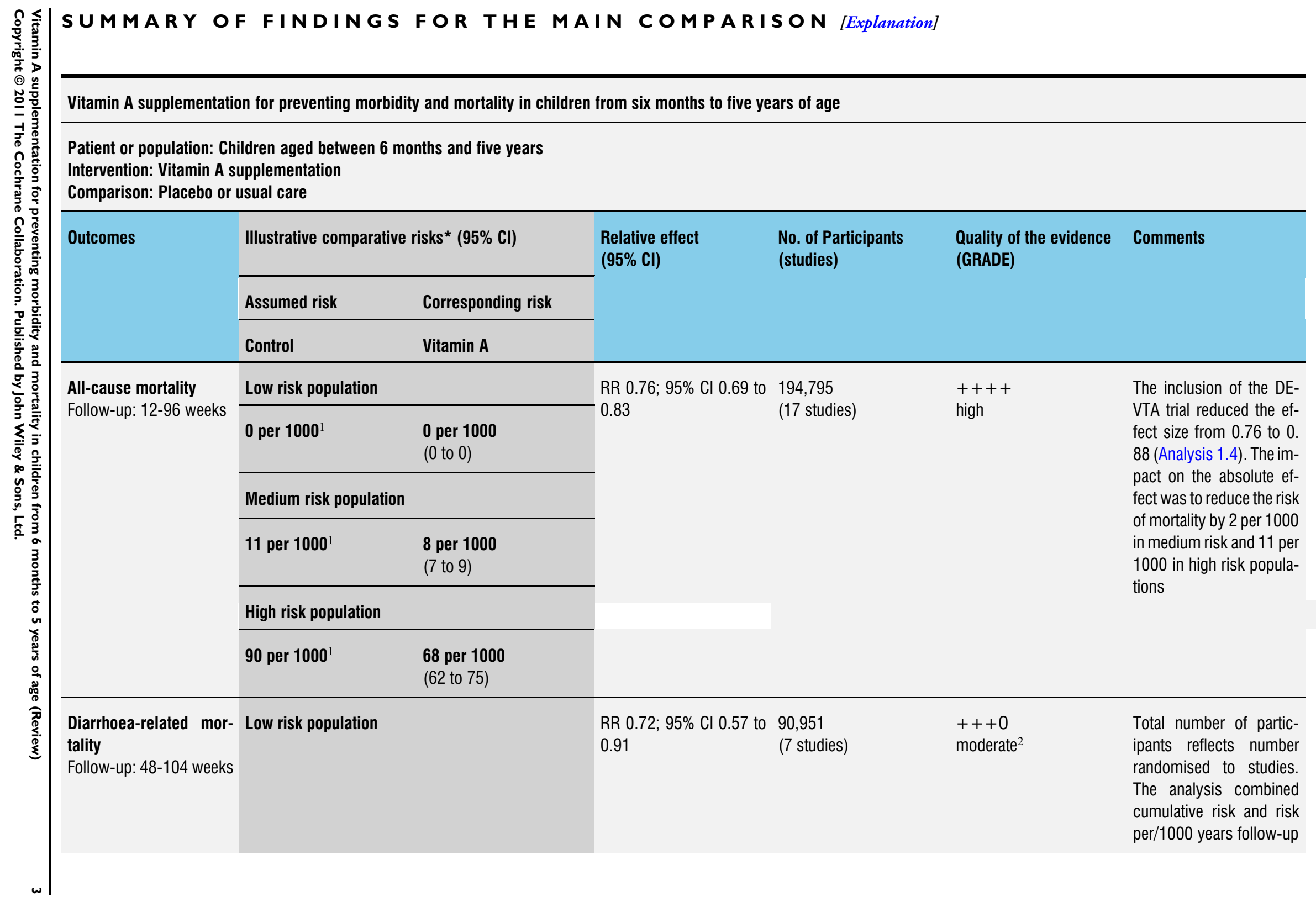




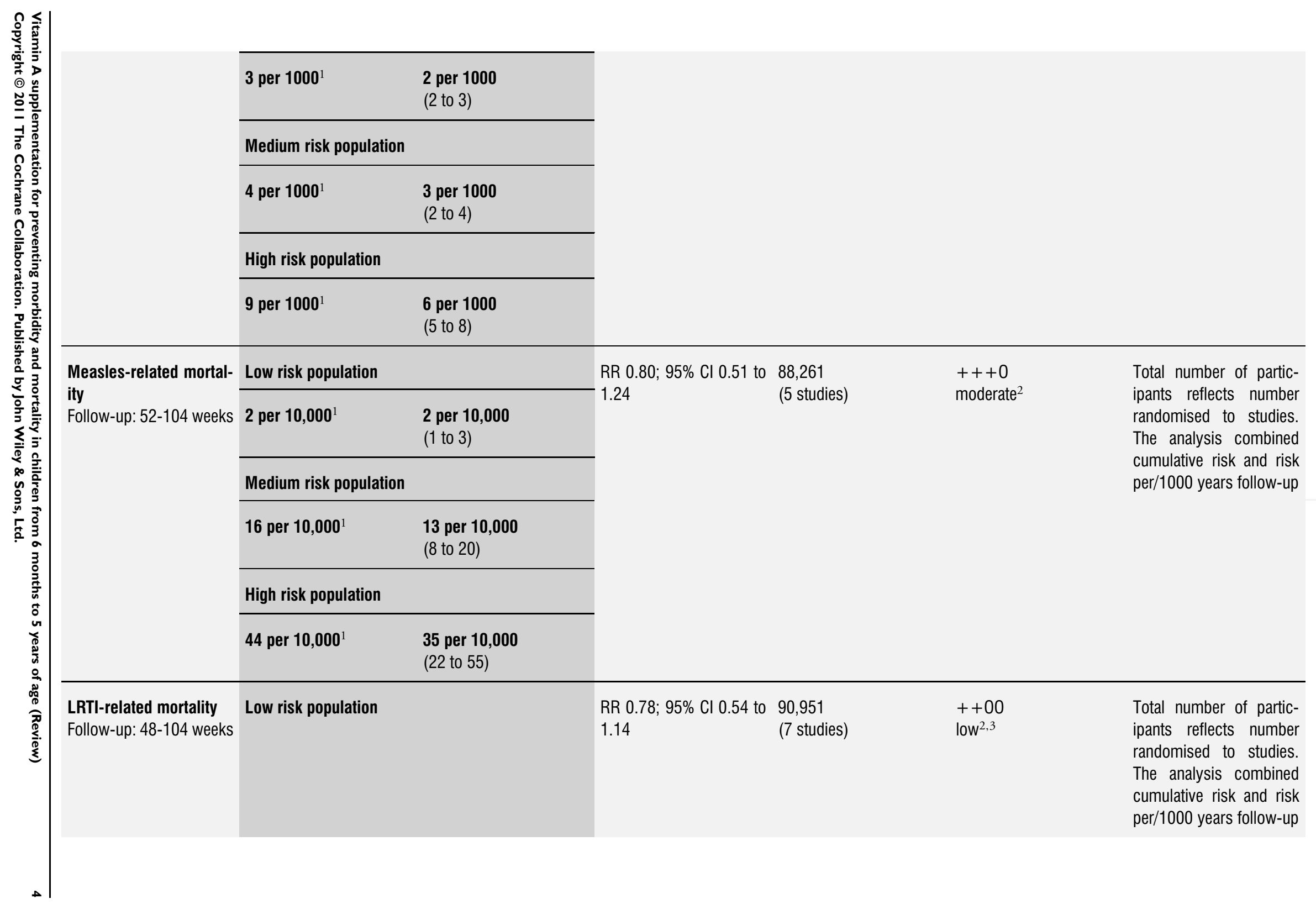




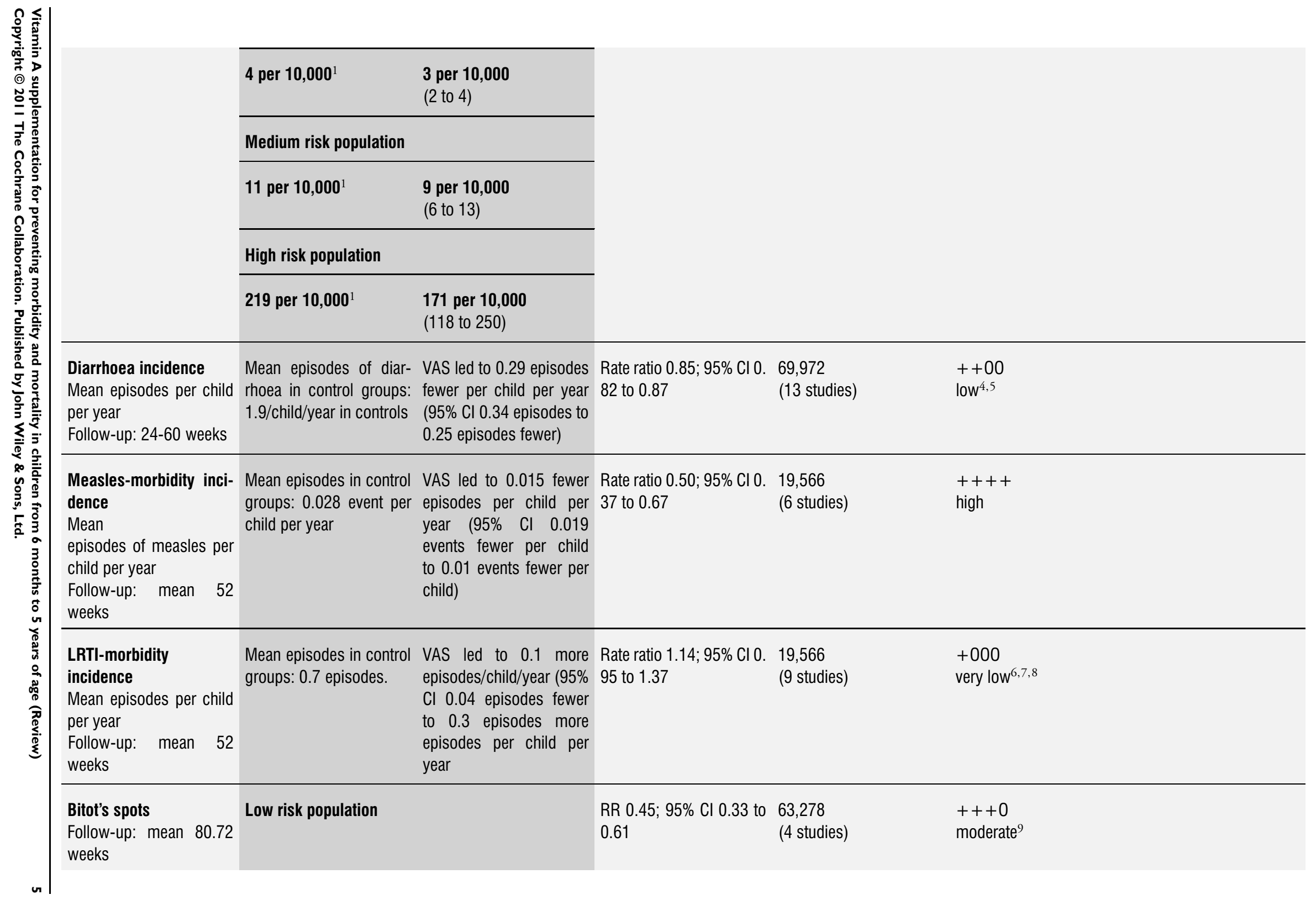




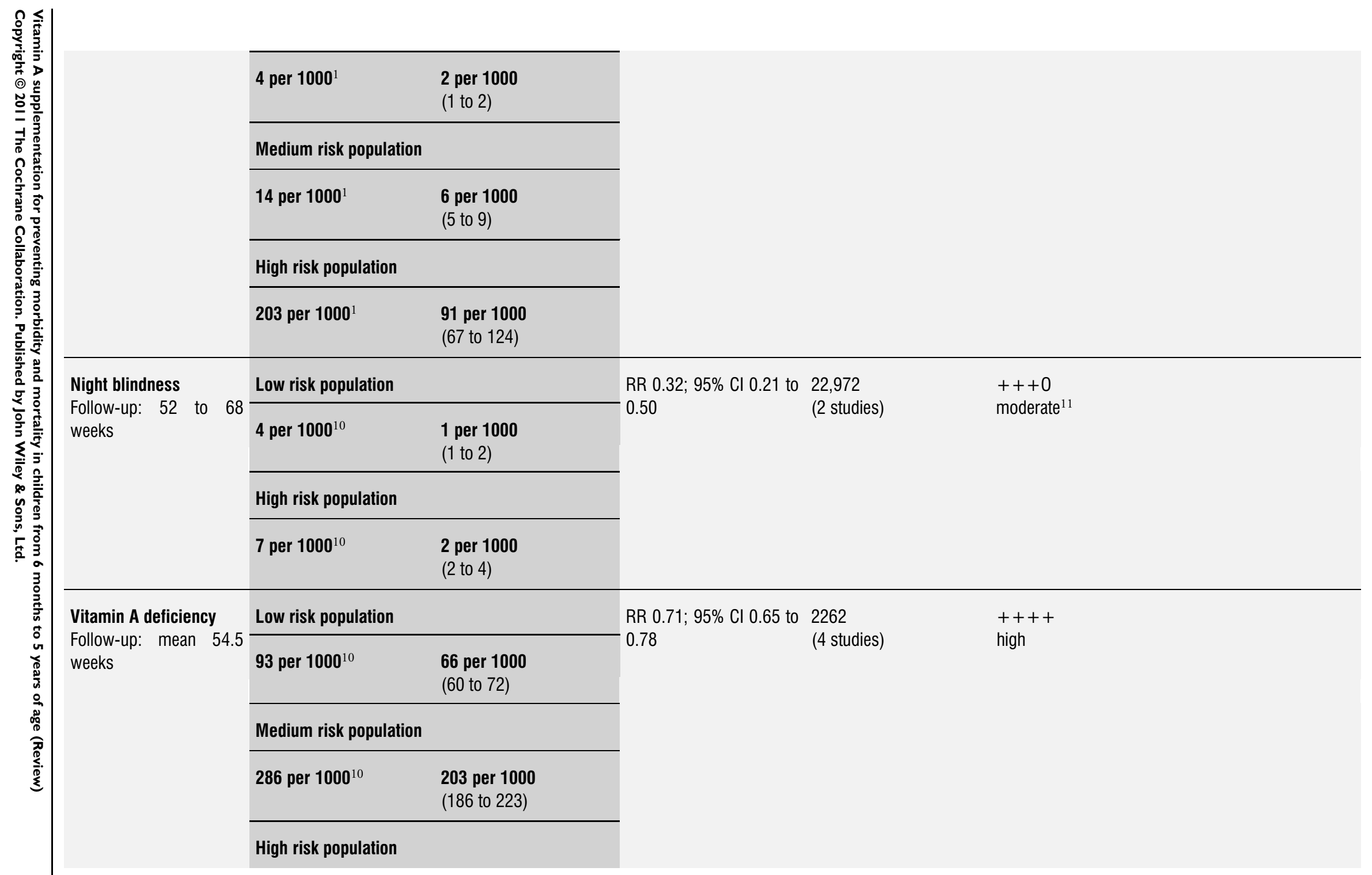




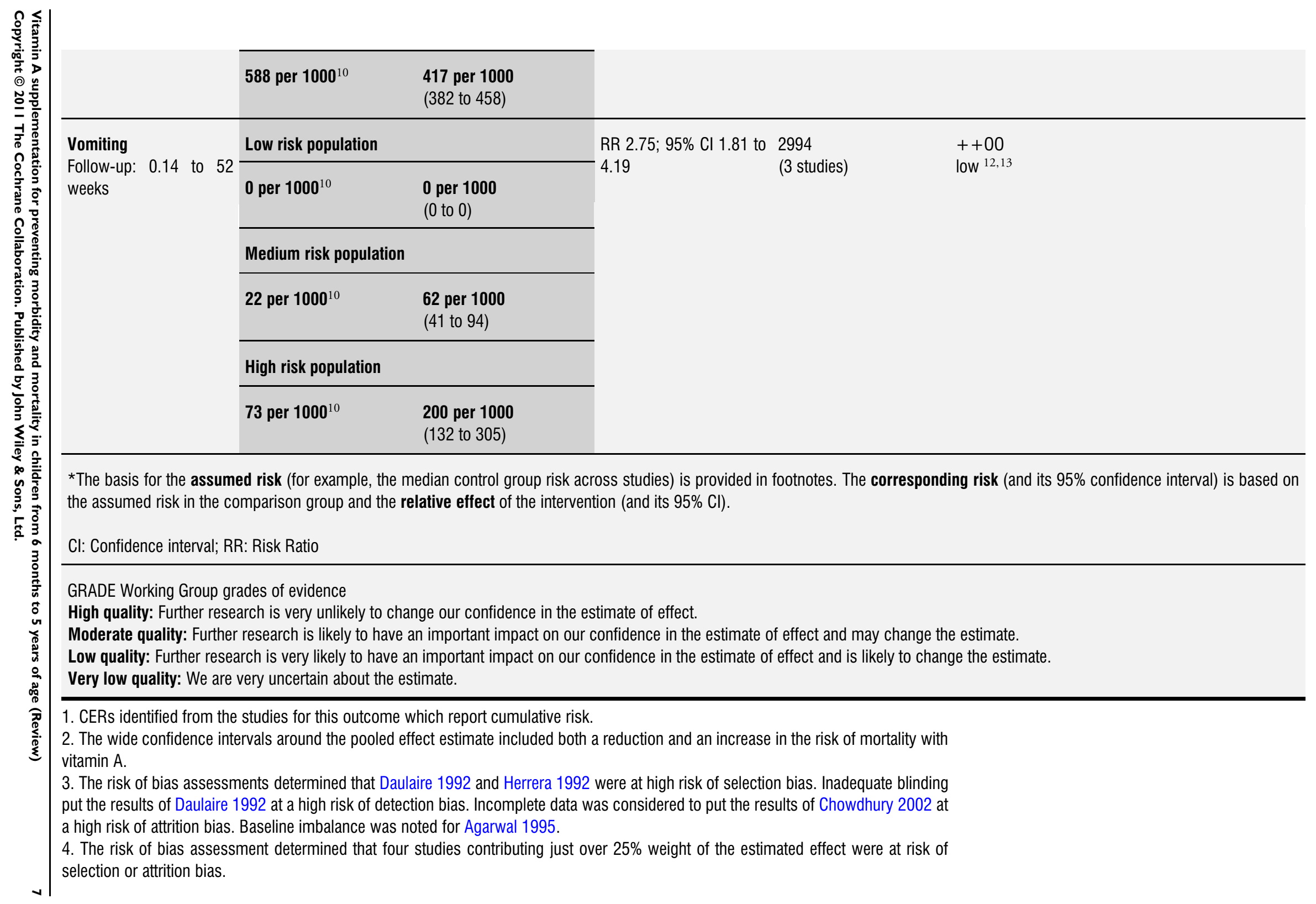


5. The I square was 95\%, and the results of Herrera 1992; Cheng 1993 and Chowdhury 2002 demonstrated clear evidence of benefit and were discordant with the results of the other studies.

6. The risk of bias assessment determined that Cheng 1993; Kartasasmita 1995 and Chowdhury 2002 were at high risk of attrition bias.

7. Diagnostic procedures were not consistent across the studies.

8. The Cls around the pooled effect included small benefit and a meaningful increase in the risk of RTIs.

9. The risk of bias assessment determined that there was a risk of attrition bias in Pant 1996, which was assigned $47 \%$ weight.

10. Risk based on CERs from the included studies.

11. The larger study was not well described and was of uncertain quality; this puts the results at a high risk of selection bias.

12. The follow-up was spread between 1 day and 52 weeks.

13. There was some evidence of under-reporting of adverse events in some of the studies, and the low number of trials giving data in relation to the large of studies included overall means that this selective reporting of adverse events cannot be excluded. 


\section{B A C K G R O U N D}

\section{Description of the condition}

Vitamin A is required for normal functioning of the visual system, maintenance of cell function for growth, epithelial integrity, red blood cell production, immunity and reproduction (Sommer 1996). Vitamin A deficiency (VAD) impairs body functions and may cause death. Adverse health consequences may also include xerophthalmia (dry eyes), susceptibility to infection, stunting and anaemia (Sommer 1996; Rice 2004). Chronic VAD may develop when animal sources and fortified foods are limited, as in diets that rely heavily on vegetables and fruits (Ramakrishnan 2002). In poor societies, especially lower income countries, dietary deficiency can begin very early in life, as when colostrum is discarded or when breastfeeding is inadequate (Haskell 1999).

VAD is interconnected with a deprived ecological, social and economic environment. People with VAD may be exposed to measles, diarrhoea and respiratory diseases (Sommer 2002; Rice 2004). When these problems are comorbid, intake of vitamin A may be lowered through depressed appetite and poor absorption, and body stores of vitamin A may be depleted through excessive metabolism and excretion (Alvarez 1995; Mitra 1998). This combination of poor diet and infection leads to a vicious cycle that particularly affects young children and pregnant or lactating mothers (Sommer 2002; West KP 2003).

VAD is common in the developing world. About 19.1 million pregnant women and 190 million children under 5 are vitamin A deficient (i.e. serum retinol $<0.70 \mu \mathrm{mol} / \mathrm{l}$ ), representing about $33 \%$ of children under 5 in populations at risk of VAD (WHO 2009). Based on biochemical VAD in young children, 122 countries have a moderate to severe public health problem (WHO 2009).

Africa and South-East Asia contain the highest proportions of pregnant females and children under 5 with biochemical VAD and night blindness (WHO 2009). Xerophthalmia is the world's leading preventable cause of blindness, and a cardinal indicator of VAD (Sommer 1996). Of the world's children with xerophthalmia, nearly half reside in South or South-East Asia, with more than $85 \%$ of these living in India (West 2002a).

\section{Description of the intervention}

Vitamin A is a term used for a subclass of retinoic acids, a family of lipid-soluble compounds (Bates 1995). Vitamin A is found in two main forms: provitamin A carotenoids and preformed vitamin A. Provitamin A carotenoids are found in plants; beta-carotene is the only one that is metabolised by mammals into vitamin A. Though fruits and vegetables are nutritious in other ways, normal dietary intake of plants may not deliver adequate amounts of vitamin A because the intestinal carotenoid-to-retinol conversion ratio is 12 :
1 (US Institute of Medicine, Food and Nutrition Board). Consequently, VAD can exist in places with high vegetable and fruit consumption (West 2002). Preformed vitamin A (retinol, retinal, retinoic acid, and retinyl esters), is the most active form of vitamin A and is found in animal sources. Supplements usually use Preformed vitamin A (Shenai 1993; Bates 1995).

\section{How the intervention might work}

Vitamin A is an essential nutrient; it cannot be synthesised by the human body and therefore must be obtained through diet (Bates 1995). Oral supplementation (VAS) and food fortification are the most direct methods for providing vitamin A to people whose diets are deficient.

Vitamin A has been described as an anti-infectious vitamin because of its role in regulating human immune function (Green 1928). Early studies in animals and humans revealed an association between VAD and increased susceptibility to infections (Semba 1999). In addition to its preventive and therapeutic effect against xerophthalmia (Sommer 1996), prophylactic VAS in apparently healthy children (over 6 months of age) residing in developing countries may reduce childhood mortality by as much as $30 \%$ (Beaton 1993; Fawzi 1993; Glasziou 1993), particularly by reducing diarrhoea and measles mortality.

Side effects of VAS are rare in children aged 6 months or older; however, vitamin A toxicity can develop if large amounts of vitamin A are used over a prolonged period of time. Symptoms of toxicity include liver damage, headaches, vomiting, skin desquamation, bone abnormalities, joint pain and alopecia (Smith 1976). A very high single dose can also cause transient acute toxic symptoms that may include a bulging fontanelle in children under 1 year, headaches, vomiting, diarrhoea, loss of appetite and irritability. Toxicity from ingestion of food sources of preformed vitamin A is rare (Hathcock 1997).

\section{Why it is important to do this review}

Prophylactic and therapeutic supplementation has been the subject of several reviews (Beaton 1993; Fawzi 1993; Glasziou 1993; Gogia 2008a). Three of these are 17 years old. The most recent one (Gogia 2008a) included studies of maternal VAS, neonatal VAS and childhood supplementation in a single meta-analysis. Direct supplementation of children and indirect methods through supplementation of breast-feeding mothers may have variable impacts on children, and supplementation may have different effects at these key developmental stages. These systematic reviews reported statistically significant reductions in all-cause child mortality. VAS appears to be a very cheap intervention that can be easily administered to children. In populations with low vitamin A status and where dietary intake of vitamin A is low, large-scale supplementation might lead to substantial public health benefits, including re- 
duced childhood mortality, infections and blindness. On the basis of previous evidence, the WHO has long recommended VAS for young children and pregnant or breastfeeding mothers at a dose of 50,000 IU for infants under 6 months of age, 100,000 IU for infants 6 to 12 months of age and 200,000 IU for children over 12 months of age, every 4 to 6 months (WHO 1997).

Several studies have been conducted since these recommendations were made over a decade ago, and this review aims to provide an up-to-date assessment of the best available evidence for VAS, including subgroup analyses to identify populations most likely to benefit and the most effective doses. Gogia 2008a did not include several known studies of VAS, so there is a need for a systematic review with a highly sensitive search strategy. The therapeutic role of vitamin A has been evaluated for measles and non-measles pneumonia in two separate Cochrane reviews (Ni 2005; Yang 2009). The prophylactic role of vitamin A has also been or is being evaluated in different Cochrane reviews in different subpopulations of children and mothers (van den Broek 2002; Wiysonge 2005; Oliveira 2006; Darlow 2007; Chen 2008; Gogia 2008; Haider 2008; Bello 2009). However, no Cochrane review has addressed prophylactic VAS in children from 6 months to 5 years of age. Given some of the recent controversies raised on the efficacy/effectiveness of VAS in developing countries (Latham 2010), it is important to review the cumulative evidence to date on the impact on health outcomes of VAS in children aged 6 months to 5 years.

\section{O B JECT IVES}

To evaluate the effect of vitamin A supplementation (VAS) in children from 6 months to 5 years of age with respect to the prevention of mortality and morbidity.

\section{METHODS}

\section{Criteria for considering studies for this review}

\section{Types of studies}

We included randomised controlled trials (RCTs) and cluster RCTs evaluating the effect of synthetic VAS in children aged 6 months to 5 years. We included data from the first period only of cross-over studies. We considered studies for inclusion irrespective of publication status or language of publication. We excluded quasi-experimental studies, such as before-after designs and observational studies.

Post hoc, we included two studies in which participants were assigned using a quasi-random method (Herrera 1992; Stansfield 1993). In both cases, the authors and the editorial team agreed that the methods of assignment (i) had the desirable characteristics of randomisation and (ii) were of no greater risk of bias than other included studies. For example, Stansfield 1993 used a random starting point and alternately assigned red or green pills. Participants received a single mega-dose of Vitamin A, so the people delivering the pills had no ongoing contact with participants; both selection bias and recruitment bias seem very unlikely.

Though the authors had access to the results of these studies, the decision to include them was made before data were extracted and before any analyses were undertaken. The search was comprehensive and we are not aware of any other studies similar to these two studies that could have been included in the review.

\section{Types of participants}

Children living in the community and aged 6 months to 5 years at the time of recruitment were eligible. Children in hospital and children with disease or infection were excluded.

We contacted trial authors if the study population included some participants who were not eligible for this review (for example, children over 5 years) and requested disaggregated data. If such data were not available, we included studies if the majority of participants $(51 \%)$ met the inclusion criteria. If this could not be determined and the participants met the inclusion criteria on average (for example, the mean age was in the eligible range), then we included these trials.

\section{Types of interventions}

Synthetic oral VAS was compared to either placebo or treatmentas-usual control groups, including trials of various doses and frequencies. Co-interventions (for example, multiple vitamin or mineral supplementation), must have been identical in both groups. We excluded studies evaluating the effects of (i) food fortification, (ii) consumption of vitamin A rich foods and (iii) beta-carotene supplementation.

If a trial included more than one eligible intervention group (for example, different doses), we combined the groups for the main analysis, although the groups were treated separately for subgroup analyses where appropriate. If a trial included multiple control groups (for example, both placebo and treatment-as-usual), we selected the control group that most closely replicated the nonspecific treatment of the intervention group (that is, placebo).

\section{Types of outcome measures}

The following outcomes were extracted. In studies reporting more than one measure of an outcome, measures were combined for meta-analysis using the methods described below (see Data synthesis). 


\section{Primary outcomes}

All-cause mortality

\author{
Secondary outcomes \\ Cause-specific mortality due to: \\ - diarrhoea; \\ - measles; \\ - meningitis; \\ - lower respiratory tract infection (LRTI). \\ Cause-specific morbidity (i.e. incidence and prevalence): \\ - diarrhoea; \\ - measles; \\ - malaria; \\ - meningitis; \\ - lower respiratory tract infection (LRTI); \\ - Bitot's spots; \\ - night blindness; \\ - xerophthalmia.
}

Side effects (for example, vomiting or diarrhoea following supplementation).

Vitamin A deficiency status (serum retinol).

\section{Search methods for identification of studies}

\section{Electronic searches}

We searched CENTRAL (The Cochrane Library 2010, Issue 2), MEDLINE (1950 to April Week 2 2010), EMBASE (1980 to 2010 Week 16), Global Health (1973 to March 2010), Latin American Database (LILACS), metaRegister of Controlled Trials and African Index Medicus. All the searches were conducted on 27 April 2010.

The search strategies for each database are included in Appendix 1. Where possible, searches were limited to clinical trials involving human subjects, and were conducted without language restriction.

\section{Searching other resources}

To identify ongoing and unpublished trials, we used the World Health Organization International Clinical Trials Registry (ICTRP), which searches multiple trial registries. Reference lists of reviews, included studies and excluded studies were searched for additional citations. We contacted organisations and researchers.

\section{Data collection and analysis}

\section{Selection of studies}

Two authors independently screened titles and abstracts for inclusion in the review (AI and $\mathrm{KH})$. We resolved differences of opinion about suitability for inclusion by discussion and through consultation with a third author (EMW). Studies that met the screening criteria but did not meet the full inclusion criteria are listed in the Characteristics of excluded studies table with the reasons for exclusion.

\section{Data extraction and management}

We used a data extraction sheet to extract the following information from each study:

- year

- location (country, urban/rural);

- method of recruitment;

- inclusion criteria;

- unit of analysis; and

- risk of bias (see below).

Participants:

- socio-demographics (age, sex); and

- co-morbidities.

For each intervention and comparison group of interest:

- dosage;

- duration;

- frequency;

- co-intervention (if any).

For each outcome of interest:

- time points (i) collected and (ii) reported;

- definition;

- validity;

- unit of measurement (if relevant); and

- loss to follow-up.

Data from each eligible study were extracted independently by two people using Distiller software. Extraction was also done by a team at the Cochrane Editorial Unit (Toby Lasserson, Rachel Murphy and Karla Soares-Weiser), but there was always at least one extractor who was an author (AI, KH, YY, EMW). Discrepancies were resolved through discussion among the authors.

The main analyses included the longest reported follow-up in each study. Outcomes were also grouped by time ( 0 to 12 months; 13 to 60 months, and greater than 60 months since randomisation); when trials reported multiple time points for a period, we extracted the longest outcome interval in a given period.

\section{Assessment of risk of bias in included studies}

Two authors independently assessed the risk of bias associated with each included study using the Risk of Bias tool (Higgins 2008). For all studies, the following were assessed: sequence generation; allocation concealment; blinding of participants, providers and outcome assessors; incomplete outcome data; and selective outcome 
reporting. We specifically looked for the possibility of performance bias (differential treatment of the intervention and control groups) and detection bias (for example, differential effort to locate death records for the intervention and control groups). Findings are discussed below and included in the Risk of Bias tables.

\section{Measures of treatment effect}

Morbidity was measured in different ways, and we combined all available data whenever possible. For example, for diarrhoea we included all types of diarrhoea (mild, moderate and severe). In the case of pneumonia, we included lower respiratory tract infection (but not upper).

To avoid reviewer bias, we predetermined the order of preference for extracting outcomes when data were available in several formats. For studies that randomised individuals, we gave preference to data that required the least manipulation by authors or inference by reviewers. We extracted raw values (for example, means and standard deviations) rather than calculated effect sizes (for example, Cohen's d). For mortality data, we gave preference to denominators in the following order: number with definite outcome known (or imputed as described below), number randomised, and child-years. For other dichotomous outcomes to which both survivors and non-survivors may contribute data (for example, incidence of measles), we gave preference to child-years, number with definite outcome known, and number randomised.

In the case of cluster RCTs, we (i) used adjusted estimates reported by the authors or (ii) used raw data and inflated the standard error (SE) using procedures described below.

\section{Unit of analysis issues}

In studies randomising units other than the individual (i.e. clusters), results should be presented with controls for clustering (for example, robust SEs or hierarchical linear models). We analysed clustered data using procedures outlined in Higgins 2008.

Where results did not control for clustering, we contacted authors to request an estimate of the intra-cluster correlation coefficient (ICC). If the authors were unable to provide an ICC, we used design effects calculated previously (Beaton 1993) to calculate the ICC, and we estimated the ICC for studies that did not publish a value (see below). For estimated values, we conducted sensitivity analyses using larger and smaller design effects to determine if the results were robust.

\section{Dealing with missing data}

Differential dropout can lead to biased estimates of effect size, and bias may arise if reasons for dropout differ across groups.

Missing data are described, including dropouts and reasons for dropout where given. If data were missing for some cases, or if reasons for dropout were not reported, we contacted the authors. When analyses were reported for completers as well as controlling for dropout (for example, imputed using regression methods), we extracted the latter.

\section{Assessment of heterogeneity}

Included studies were assessed for clinical heterogeneity by comparing the distribution of important factors, such as study participants, study setting, dose and duration of intervention and cointerventions. Methodological heterogeneity was assessed by comparing data included in the Risk of Bias tables. Statistical heterogeneity was assessed by visual inspection of forest plots, by performing the $\mathrm{Chi}^{2}$ test (assessing the $\mathrm{P}$ value) and by calculating the $\mathrm{I}^{2}$ statistic. If the $\mathrm{P}$ value was less than 0.10 and $\mathrm{I}^{2}$ exceeded $50 \%$, we considered heterogeneity to be substantial.

\section{Assessment of reporting biases}

To assess the possibility of small study bias, funnel plots were drawn for outcomes with 10 or more studies and random effects estimates were compared to the fixed effect estimate (see below).

\section{Data synthesis}

We performed meta-analysis using Review Manager Software Version 5 (RevMan 2008). When data were extracted in several formats that could not be combined directly in RevMan, we used the generic inverse variance option; data were entered into Comprehensive Meta-Analysis Version 2 and the $\log$ RR and SE were entered into RevMan.

All outcomes are reported with 95\% confidence intervals (CI), and overall effects are weighted by the inverse of variance using a fixed-effect model; although there may be some differences across trials (for example, dose and population), the biological mechanism should be similar across trials and we will explore differences through analyses described elsewhere.

For dichotomous outcomes, we calculated the overall Risk Ratio (RR). For incidence data, Risk Ratio (events per child) and Rate Ratio (events per child-year) were combined because these ratios use the same scale and can be interpreted in the same way for these studies (the duration of studies was short, there was no interaction between the intervention and time at risk). In some cases, we estimated time at risk, as when authors reported incidence rate, duration of the study and number of children in the group.

For continuous outcomes we calculated Hedges $g$.

\section{Subgroup analysis and investigation of heterogeneity}

Effectiveness may differ across members of populations (for example, due to differences in baseline vitamin A status) and may be affected by other interventions (for example, immunisation or deficiency of other micronutrients). For example, neonatal VAS is thought to have different effects in Asia versus Africa (Klemm 2009). Unlike trial-level factors (such as dose), associations between individual-level moderators (such as vitamin A status) and 
outcomes should be analysed using individual patient data from RCTs and observational studies. With two exceptions, we did not include subgroup analyses based on individual-level moderators in this review, as such analyses are at high risk of the ecological fallacy (for example, lack of variation between studies would not indicate there was no variation within them). We included subgroups of age and gender; trials commonly report separate effects for these groups.

The following subgroup analyses were prespecified, and differences were tested using the $\mathrm{Chi}^{2}$ test in RevMan:

1. Dose: Standard (up to 100,000 IU for children 6 to 11 months of age, and 200,000 IU for children 12 months to 5 years of age) versus High (greater than standard).

2. Frequency: High (doses within 6 months) versus Low (1 dose or $6+$ month interval).

3. Location: Continent.

4. Age: 6 to 12 months versus 1 to 5 years.

5. Sex: males versus females.

\section{Sensitivity analysis}

Sensitivity analyses were performed as follows:
1) To test for bias, the primary analysis was repeated without studies at high risk of bias for sequence generation. To test for small study bias, the analysis was repeated using a random-effects model and funnel plots were drawn for all outcomes with 10 or more studies.

2) Imputed ICC (a post-hoc analysis described below).

3) Studies awaiting assessment (a post-hoc analysis described below).

\section{R E S U L T S}

\section{Description of studies}

\section{Results of the search}

Electronic searches identified 6683 citations; 4600 citations remained after duplicates were removed.

Additionally, we reviewed 129 studies from reference lists. There were 371 relevant citations, and all full texts were reviewed, see Figure 1. 
Figure I. Flow diagram for selection of studies

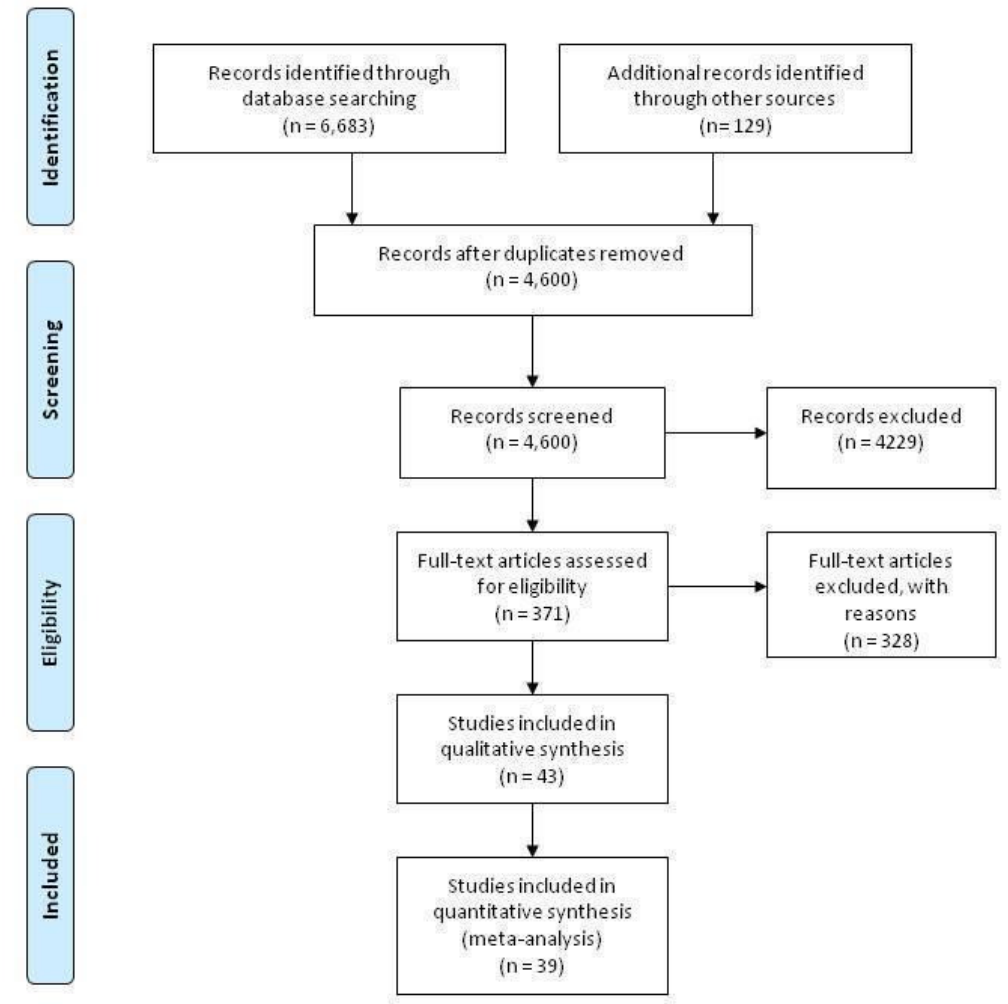

\section{Included studies}

Forty-three trials reported in 90 papers met the inclusion criteria, including factorial studies that were treated as two trials for metaanalysis (described below). More than one report was available for $16(37 \%)$ trials. Where multiple reports existed for an included trial, we extracted data from all reports. Further information about individual studies is included in the Characteristics of included studies tables.

Thirty-nine trials (91\%) reported data that could be included in a meta-analysis; four trials reported either outcomes that were not relevant to the review (Cherian 2003), or data that were not available by group (Lima 2010) or were incomplete (van Agtmaal 1988; Smith 1999).

\section{Sample size}

Trials assigned approximately 215,633 participants, with sample sizes ranging between 35 (van Agtmaal 1988) and approximately 29,236 (Sommer 1986), and a median sample size of 480. The 39 trials that could be analysed included 215,043 participants $(99.7 \%$ of children included in the review).

The ten largest studies randomised about 200,214 children, 93\% of participants in the review (Sommer 1986; Rahmathullah 1990; Vijayaraghavan 1990; West 1991; Daulaire 1992; Herrera 1992; Ross 1993 SURVIVAL; Stansfield 1993; Agarwal 1995; Pant 1996).

\section{Comparisons}

Six (14\%) studies compared VAS to treatment-as-usual; 37 (86\%) compared VAS to placebo. One large trial reported they did not use a placebo because it was forbidden by government (Sommer 1986).

\section{Multiple trial arms}

Twelve trials (28\%) had multiple arms, 7 of which were relevant to the review (Reddy 1986; Florentino 1990; Benn 1997; Smith 1999; Rahman 2001; Long 2006; Lin 2009). 
Four trials used factorial designs, combining vitamin A with other treatments such as zinc (Smith 1999; Rahman 2001; Long 2006) or deworming (Reddy 1986); data were extracted for comparisons that differed only in the provision of vitamin A (for example, vitamin A versus placebo; and vitamin A plus zinc versus zinc only). In one trial (Rahman 2001), raw data were not available and we could not identify outcome data for an eligible comparison. Different doses were combined in one study (Florentino 1990).

\section{Unit of randomisation}

Two studies (Herrera 1992; Stansfield 1993) randomised by household and we treated participants as if they were individually randomised. A sensitivity analysis was conducted for all-cause mortality, using ICCs of 0 and 0.01 for those studies in which the mean design effect was estimated.

Previously reported design effects from Beaton 1993 were used to calculate ICCs for clustered studies (Sommer 1986; Rahmathullah 1990; Vijayaraghavan 1990; West 1991; Daulaire 1992; Ross 1993 SURVIVAL). The ICCs were consistent around a value of 0.002 . We imputed an ICC value of 0.002 for all studies in which clustering was not accounted for in the original analysis.

\section{Allocation ratio}

Participants were evenly allocated to the intervention and control groups in 35 studies $(81 \%)$ and the number assigned to each group was unclear in 8 trials (19\%) (Reddy 1986; Ross 1993 HEALTH; Ross 1993 SURVIVAL; Stansfield 1993; Biswas 1994; Dibley 1994; Ramakrishnan 1995; Pant 1996).

\section{Location/setting}

Trials were conducted in 19 countries: 27 (63\%) in Asia, 15 of these in India; 7 (16\%) in Africa; 7 (16\%) in Latin America, and $2(5 \%)$ in Australia. Sixteen (37\%) of the studies were conducted in urban/peri-urban settings and $24(56 \%)$ in rural settings, while three studies did not explicitly described their urban/rural setting.

\section{Age}

Average age was reported in 19 trials (44\%). The median of the mean ages was 30.5 months.

\section{Sex}

Sex was reported in 32 trials (72\%). The majority assigned approximately equal numbers of males and females. Three studies
(Semba 1992; Ranjini 2001; Lin 2008) favoured males by more than $10 \%$. The median study included $51 \%$ males.

\section{Time}

Outcomes measured at different times ( 0 to 12 months, 13 to 60 months, and 60 or more months) were collapsed for one overall analysis. Most studies lasted about a year, and dividing studies of similar length created potentially confusing/misleading subgroups. In the event that a single study reported data in more than one time point interval, the data from the longest interval was used in the overall analysis.

\section{Excluded studies}

After reviewing articles, 328 papers were excluded; eight nearly met the inclusion criteria, and reasons for exclusion are provided in Characteristics of excluded studies.

\section{Studies awaiting assessment}

Two trials could not be assessed at this time. One trial (Aklamati 2006) was reported in a conference abstract. It appeared to meet the inclusion criteria, but reported impossible results. For example, the study included 36 children and reported an outcome of $1.2 \%$ of 17 ; though 1 child out of 17 is nearly $6 \%$. We have contacted the authors for clarification and the study may be included in future versions of this review.

Importantly, one completed trial appears likely to meet the eligibility criteria and may be included in further updates of this review (DEVTA trial 2007). DEVTA is the largest randomised controlled trial ever conducted, including approximately one million children. That is, the trial included four times the combined participants of all included studies in this review. We contacted the authors of this trial several times prior to the completion of this review for information required to evaluate the conduct of the study and its outcomes. They provided an early analysis of the primary outcome, mortality, as well as cause-specific mortality and vitamin A serum level.

To assess how the results of DEVTA might impact the conclusions of this review, a sensitivity analysis was conducted. Due to lack of additional information, reasons for differences between this trial and other trials in the review could not be assessed.

\section{Risk of bias in included studies}

The risk of bias in each of the five domains was assessed for each study as High, Low or Unclear, see Figure 2. 
Figure 2. Risk of bias summary: review authors' judgements about each risk of bias item for each included study.

\begin{tabular}{|c|c|c|c|c|c|c|c|c|}
\hline & 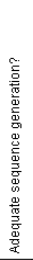 & 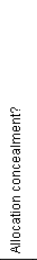 & 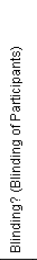 & 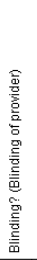 & 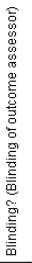 & 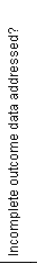 & 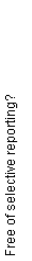 & 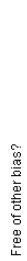 \\
\hline Agarwal 1995 & $?$ & $?$ & $?$ & ? & ? & ? & ? & $?$ \\
\hline Arya 2000 & ○ & $?$ & + & $\odot$ & + & ○ & - & $\oplus$ \\
\hline Bahl 1999 & ๑ & $?$ & $\odot$ & $\odot$ & ๑ & ○ & $\ominus$ & (†) \\
\hline Barreto 1994 & $?$ & † & ๑) & ๑ & $\odot$ & ๑ & ? & 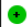 \\
\hline Benn 1997 & (†) & $(+$ & (†) & () & ๑) & + & (†) & $?$ \\
\hline Biswas 1994 & ๑ & (†) & (†) & ๑) & ๑) & ๑) & $?$ & 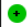 \\
\hline Cheng 1993 & $?$ & $?$ & (†) & (†) & $\odot$ & ○ & $?$ & + \\
\hline Cherian 2003 & $?$ & ๑ & $?$ & $?$ & $?$ & $\ominus$ & ○ & $?$ \\
\hline Chowdhury 2002 & $?$ & $?$ & $?$ & $?$ & $?$ & - & $?$ & $?$ \\
\hline Daulaire 1992 & † & - & - & ? & ? & ๑ & $?$ & + \\
\hline DEVTA 2007 & & & & & & & & \\
\hline Dibley 1994 & (†) & $\odot$ & - & † & $\odot$ & ๑) & ๑ & (†) \\
\hline Donnen 1998 & $?$ & $?$ & $?$ & $?$ & ? & ๑ & $?$ & $\odot$ \\
\hline Florentino 1990 & $?$ & $?$ & $\odot$ & ๑ & ๑ & ๑ & $\odot$ & $\oplus$ \\
\hline Herrera 1992 & అ & $?$ & 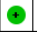 & † & $\odot$ & ๑) & $?$ & $?$ \\
\hline Kartasasmita 1995 & $?$ & $?$ & $?$ & ? & $?$ & - & $?$ & $?$ \\
\hline Lima 2010 & $\odot$ & $?$ & (†) & ๑) & ๑ & ๑ & అ & 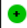 \\
\hline Lin 2008 & $?$ & $?$ & (†) & $?$ & $?$ & (†) & ○ & $?$ \\
\hline Lin 2009 & (†) & $?$ & - & - & ○ & ๑) & ○ & $\odot$ \\
\hline Long 2006 & $\odot$ & ๑ & ๑ & ๑) & ๑ & ๑ & $?$ & ๑ \\
\hline \multicolumn{9}{|l|}{ Long 2006 (2) } \\
\hline Long 2007 & ๑ & ๑ & ๑ & - & - & ๑ & ? & $\odot$ \\
\hline Pant 1996 & $\odot$ & $?$ & $?$ & $?$ & $?$ & - & ○ & $?$ \\
\hline Pinnock 1986 & (†) & $?$ & (†) & (†) & ๑ & • & ? & $\oplus$ \\
\hline Pinnock 1988 & ๑ & ๑ & (†) & $\odot$ & ๑ & ๑) & ○ & 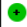 \\
\hline Rahman 2001 & ๑) & ๑ & $\odot$ & ๑ & ๑ & ๑ & $?$ & $\oplus$ \\
\hline Rahmathullah 1990 & $?$ & $\odot$ & ๑ & $\odot$ & $\odot$ & ๑) & ๑) & $\oplus$ \\
\hline Ramakrishnan 1995 & $?$ & ? & ๑ & $\oplus$ & ๑ & ๑ & అ & $\oplus$ \\
\hline Raninini 2001 & $?$ & $?$ & $?$ & $?$ & ? & ? & $?$ & $?$ \\
\hline Reddy 1986 & $?$ & $?$ & $?$ & $?$ & $?$ & $?$ & $?$ & $?$ \\
\hline \multicolumn{9}{|l|}{ Reddy 1986 (2) } \\
\hline Ross 1993 HEALTH & $?$ & † & (†) & - & ๑ & ? & ○ & 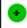 \\
\hline Ross 1993 SURVIVAL & $?$ & (†) & (†) & $\odot$ & $\odot$ & ? & - & $?$ \\
\hline Semba 1992 & $?$ & ๑) & ๑ & ๑ & ? & ๑) & $?$ & $?$ \\
\hline Semba 1995 & ๑ & (†) & ๑) & ๑) & ๑ & - & $?$ & $?$ \\
\hline Sempertegui 1999 & ๑) & $\odot$ & (†) & - & ๑ & ๑) & $?$ & 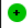 \\
\hline Shankar 1999 & ๑ & $\odot$ & + & ๑) & † & ๑) & $?$ & $\odot$ \\
\hline Sinha 1976 & $?$ & $?$ & (†) & - & ๑) & ? & $?$ & $\oplus$ \\
\hline Smith 1999 & $?$ & $?$ & $?$ & $?$ & ? & ? & $?$ & $?$ \\
\hline Sommer 1986 & $?$ & $?$ & ? & ? & $?$ & ? & $?$ & $?$ \\
\hline Stabell 1995 & $?$ & $?$ & $?$ & ? & $?$ & ? & $?$ & $?$ \\
\hline Stansfield 1993 & ○ & ๑ & ๑) & (†) & ๑ & ๑ & అ & $\odot$ \\
\hline van Agtmaal 1988 & $?$ & $?$ & ? & $?$ & ? & - & - & $?$ \\
\hline Venkatarao 1996 & $?$ & $?$ & $(\oplus$ & (†) & $\odot$ & ? & $\odot$ & $\oplus$ \\
\hline Vijayaraghavan 1990 & $?$ & $?$ & ๑ & ๑) & ๑ & ? & - & ๑ \\
\hline West 1991 & $?$ & $?$ & $\odot$ & (†) & ๑ & ? & (†) & 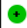 \\
\hline
\end{tabular}




\section{Allocation}

\section{Sequence generation}

All included studies were randomised or quasi-randomised controlled trials: 19 (44\%) specified the method of randomisation and $16(37 \%)$ were at Low risk of bias for sequence generation.

Three trials $(7 \%)$ were at High risk of bias for sequence generation (Herrera 1992; Stansfield 1993; Arya 2000). These included 41,139 participants (19\% of those included in the review).

One described assignment as random, but participants may have been assigned in order of arrival at hospital (Arya 2000).

Though technically quasi-random, we included two trials post hoc (Herrera 1992; Stansfield 1993) because the generation of the allocation sequence was not likely to result in systematically different groups. Given the design of the interventions and the placebos and steps to blind those administering the sequence, the reviewers do not think these studies are meaningfully different from randomised trials. In the first, participants were assigned alternately by household (Herrera 1992). The second used a random starting point and alternating distribution of red or green pills (Stansfield 1993). Lack of a truly random sequence was not related to other sources of bias (for example, performance bias) as individuals delivering the capsules had no ongoing contact with participants and the manufacturer (Roche) held the code until the study was completed. Though post-hoc, the decision to include these studies was made before data were extracted and before any analyses had been conducted; a sensitivity analysis was conducted (below) to determine if the decision had any impact on the results and it did not.

\section{Allocation concealment}

Allocation concealment is adequate when (i) trial staff and potential participants are unaware of assignments at the time of recruitment into the trial and (ii) the generation of the allocation sequence is protected from the influence of anyone aware of the participants' characteristics. Allocation concealment was coded as High risk of bias for only one study (Daulaire 1992) and Unclear for 27 studies (63\%). In most studies it was impossible to assess allocation concealment. Efforts to blind participants and providers suggest the overall risk of bias is minimal, and any impact on the primary outcome (all-cause mortality) is likely to be small.

\section{Blinding}

The intervention was conducive to blinding. Though there is some evidence that very large doses of vitamin A can lead to short-term side effects, participants and providers would not normally become aware of assignment after delivery of vitamin A in the form of pills, capsules or liquid solution. Efforts to blind participants and providers were described in 29 of the studies (67\%), which were at Low risk of bias. In some trials, staff delivering the intervention also conducted assessments. Blinding of assessors was at High risk of bias in two studies (Daulaire 1992; Lin 2009) and Unclear in 14 (Reddy 1986; Sommer 1986; van Agtmaal 1988; Semba 1992; Agarwal 1995; Kartasasmita 1995; Stabell 1995; Pant 1996; Donnen 1998; Smith 1999; Ranjini 2001; Chowdhury 2002; Cherian 2003; Lin 2008).

In some trials, children interacted with researchers or clinicians who were aware of their assignment. Two studies (5\%) were at High risk of performance bias, mostly because of failure to adequately blind staff, whereas 28 (65\%) were at Low risk of performance bias. The reviewers considered bias due to inadequate blinding to be low and, if anything, likely to underestimate effects; for example, a teacher would be more likely to give extra food to a child receiving placebo rather than the reverse.

The review authors consider the primary outcome, mortality, is very unlikely to have been influenced by lack of blinding.

\section{Incomplete outcome data}

For incomplete outcome data, 23 trials (53\%) were at Low risk of bias; 8 (17\%) were at High risk of bias (van Agtmaal 1988; Kartasasmita 1995; Semba 1995; Pant 1996; Bahl 1999; Arya 2000; Chowdhury 2002; Cherian 2003) and 12 (28\%) were Unclear (Sinha 1976; Reddy 1986; Sommer 1986; Vijayaraghavan 1990; West 1991; Ross 1993 HEALTH; Ross 1993 SURVIVAL; Agarwal 1995; Stabell 1995; Venkatarao 1996; Smith 1999; Ranjini 2001).

Missing data are much more likely to influence secondary analyses than the primary outcome. Results for all-cause mortality are known for $91 \%$ of randomised participants. Of the 17 studies (40\%) that reported this outcome, 7 were Unclear, but 4 of these had minimal attrition (Vijayaraghavan 1990; Ross 1993 HEALTH; Ross 1993 SURVIVAL; Venkatarao 1996) and the others failed to report reasons for dropout. In 2 studies, missing data were not adequately handled (Pant 1996; Chowdhury 2002), but together these studies contributed only $5 \%$ to the pooled estimate.

\section{Selective reporting}

Most of the trials in the review included multiple outcome measures, and positive results are more likely to be included in reports than negative results. Only 5 (12\%) trials appeared to be free of selective outcome reporting (Florentino 1990; Rahmathullah 1990; West 1991; Dibley 1994; Benn 1997). Twenty four (56\%) were Unclear, while 14 (33\%) were at High risk of bias (Pinnock 1988; van Agtmaal 1988; Vijayaraghavan 1990; Ross 1993 HEALTH; 
Ross 1993 SURVIVAL; Stansfield 1993; Ramakrishnan 1995; Pant 1996; Bahl 1999; Arya 2000; Cherian 2003; Lin 2008; Lin 2009; Lima 2010).

For the primary outcome, there is no meaningful risk of bias; the outcome was reported for large trials. Data were missing in small studies of short duration, which likely observed few deaths. For many of the secondary analyses, which included only a few trials representing a small proportion of the overall sample, adding unreported data might influence the observed effects.

\section{Other potential sources of bias}

Other potential sources of bias were extracted and are noted in the Characteristics of included studies tables, but none were likely to meaningfully influence the results of the review.

\section{Effects of interventions}

See: Summary of findings for the main comparison

Results for each outcome are presented below, the most important of which are described in Summary of findings for the main comparison.

Because most analyses contained a small number of studies, sensitivity analyses were restricted to the primary outcome.

Pneumonia and lower respiratory tract infection (LRTI) outcomes were combined post hoc. Pneumonia is a type of LRTI, and most of the studies did not test for pneumonia specifically (with a specific clinical criteria). In the event a study reported both pneumo- nia and LRTI outcomes, the LRTI outcome data were extracted for combination with other studies.

Not all subgroup analyses were conducted. For the primary outcome, only one study used a non-standard dose and this study also used a different frequency. Other analyses with more than 10 studies contained significantly fewer participants (for example, the analysis of serum level included less than 7000) and subgroup analyses for dose and frequency were not conducted because the analyses were clearly underpowered and any effects would be attributable to chance. Results of some of the attempted subgroup analyses are listed in Table 1 .

\section{I.0 All-cause mortality}

Seventeen trials (Sommer 1986; Rahmathullah 1990; Vijayaraghavan 1990; West 1991; Daulaire 1992; Herrera 1992; Ross 1993 HEALTH; Ross 1993 SURVIVAL; Barreto 1994; Dibley 1994; Agarwal 1995; Pant 1996; Venkatarao 1996; Benn 1997; Donnen 1998; Chowdhury 2002; Lin 2008) contributed 194,795 children (90\% of the children included in the review) in an overall analysis (using data from the last follow up for trials measuring outcomes multiple times). One reported no events (Lin 2008).

Vitamin A was associated with a $24 \%$ reduction in all-cause mortality $(\mathrm{RR}=0.76(95 \% \mathrm{CI} 0.69$ to 0.83$))$, though there was moderate heterogeneity $\left(\mathrm{Chi}^{2}=29.10, \mathrm{df}=15(\mathrm{P}=0.02) ; \mathrm{I}^{2}=48 \%\right)$ Figure 3 .

Figure 3. Forest plot of comparison: I Vitamin A versus Control, outcome: I.I Mortality (all-cause) at Longest Follow-up.

\begin{tabular}{|c|c|c|c|c|c|c|c|}
\hline Study or Subgroup & log[Risk Ratio] & SE & Weight & $\begin{array}{l}\text { Risk Ratio } \\
\text { N, Fixed, } 95 \% \mathrm{Cl}\end{array}$ & \multicolumn{3}{|c|}{$\begin{array}{c}\text { Risk Ratio } \\
\text { N, Fixed, 95\% Cl }\end{array}$} \\
\hline Lin 2008 & 0 & 0 & & Not estimable & & & \\
\hline Dibley 1994 & -1.12232882 & 1.63299316 & $0.1 \%$ & $0.33[0.01,7.99]$ & & & \\
\hline Barreto 1994 & 0 & 0.99838579 & $0.2 \%$ & $1.00[0.14,7.08]$ & & & \\
\hline Chowdhury 2002 & -1.94194975 & 0.75418055 & $0.4 \%$ & $0.14[0.03,0.63]$ & & & \\
\hline Venkatarao 1996 & -1.00252208 & 0.67056359 & $0.5 \%$ & $0.37[0.10,1.37]$ & & & \\
\hline Benn 1997 & -0.77629472 & 0.59367542 & $0.7 \%$ & $0.46[0.14,1.47]$ & & & \\
\hline Donnen 1998 & -0.51082562 & 0.48464603 & $1.0 \%$ & $0.60[0.23,1.55]$ & & & \\
\hline Ross 1993 HEALTH & -1.21578729 & 0.46547467 & $1.1 \%$ & $0.30[0.12,0.74]$ & & & \\
\hline Agarwal 1995 & 0.19717994 & 0.31208317 & $2.5 \%$ & $1.22[0.66,2.25]$ & & & \\
\hline Vijayaraghavan 1990 & 0.01685569 & 0.2971801 & $2.7 \%$ & $1.02[0.57,1.82]$ & $\longrightarrow$ & & \\
\hline Pant 1996 & -0.56211892 & 0.222204 & $4.9 \%$ & $0.57[0.37,0.88]$ & $\rightarrow$ & & \\
\hline Rahmathullah 1990 & -0.77652879 & 0.21976998 & $5.0 \%$ & $0.46[0.30,0.71]$ & $\rightarrow$ & & \\
\hline Sommer 1986 & -0.30788478 & 0.15462932 & $10.1 \%$ & $0.73[0.54,1.00]$ & $\mp$ & & \\
\hline Daulaire 1992 & -0.30110509 & 0.14994833 & $10.7 \%$ & $0.74[0.55,0.99]$ & - & & \\
\hline Herrera 1992 & 0.05826891 & 0.13093651 & $14.1 \%$ & $1.06[0.82,1.37]$ & & + & \\
\hline West 1991 & -0.35667494 & 0.11530445 & $18.1 \%$ & $0.70[0.56,0.88]$ & $\rightarrow$ & & \\
\hline Ross 1993 SURVIVAL & -0.21072103 & 0.09323125 & $27.8 \%$ & $0.81[0.67,0.97]$ & 붑 & + & \\
\hline \multicolumn{3}{|l|}{ Total $(95 \% \mathrm{Cl})$} & $100.0 \%$ & $0.76[0.69,0.83]$ & 1 & & \\
\hline \multicolumn{3}{|c|}{$\begin{array}{l}\text { Heterogeneity: } \mathrm{Chi}^{2}=29.10, \mathrm{df}=15(\mathrm{P}=0.02) ; \mathrm{I}^{2}=48 \% \\
\text { Test for overall effect: } Z=5.66(P \leq 0.00001)\end{array}$} & & & $\begin{array}{cc}0.005 & 0.1 \\
\text { avours experimental }\end{array}$ & $1 \frac{10}{\text { Favours }}$ & 200 \\
\hline
\end{tabular}

Vitamin A supplementation for preventing morbidity and mortality in children from 6 months to 5 years of age (Review) 
The effect during the first year of life was similar $(R R=0.82(95 \%$ CI 0.74 to 0.91$)$ ), but the statistical heterogeneity was substantial $\left(\mathrm{Chi}^{2}=33.85, \mathrm{df}=11(\mathrm{P}=0.0004) ; \mathrm{I}^{2}=67 \%\right)$. Only 5 trials $(7 \%)$ measured mortality between 13 and 60 months, and the effect was similar ( $R R=0.75(95 \%$ CI 0.64 to 0.88$)$ ) with moderate and significant statistical heterogeneity $\left(\mathrm{Chi}^{2}=9.29, \mathrm{df}=4(\mathrm{P}=0.05)\right.$; $\left.I^{2}=57 \%\right)$.

\section{Subgroup analyses}

\section{Dose and frequency}

Only one study reporting all-cause mortality did not use the standard dose recommended by WHO. Rahmathullah 1990 used weekly dose for 52 weeks. The planned subgroup analysis was not conducted.

\section{Location}

Eleven trials were conducted in Asia $(\mathrm{RR}=0.69$ (95\% CI 0.61 to 0.79$)), 5$ in Africa $(R R=0.85(0.73$ to 0.98$))$, and 1 in Latin America $(R R=1.00$ (0.14 to 7.08$)$ ). These were not significantly different $(\mathrm{P}=0.12$, see Table 1$)$.

\section{Age}

Four trials (Rahmathullah 1990; West 1991; Daulaire 1992; Benn 1997) reported separate effects for children aged 6 to 12 months $(\mathrm{RR}=0.59(95 \% \mathrm{CI} 0.43$ to 0.82$))$ and children aged 1 to 5 years $(R R=0.68(0.57$ to 0.81$))$; the subgroups did not differ significantly $(\mathrm{P}=0.46)$. Notably, both effect estimates are larger than the overall result from 17 trials reporting mortality.

\section{Sex}

Five trials (Sommer 1986; West 1991; Daulaire 1992; Herrera 1992; Lin 2008) reported separate effects for males $(R R=0.80$ (95\% CI 0.66 to 0.97$)$ ) and females ( $\mathrm{RR}=0.7995 \% \mathrm{CI} 0.65$ to $0.95)$, which were not significantly different $(\mathrm{P}=0.89)$. Notably, both effect estimates are larger than the overall result from 17 trials reporting mortality.

\section{Sensitivity analyses}

\section{Bias}

Of the trials at High risk of bias due to sequence generation, only Herrera 1992 contributed to the main mortality analysis and reported no effect $(\mathrm{RR}=1.06(95 \% \mathrm{CI} 0.82$ to 1.37$))$, indicating that these trials were not likely to influence the results in a positive direction.

To test for small study bias, we repeated the analysis using a random-effects model. The overall estimate was slightly larger than the fixed-effect estimate, suggesting that heterogeneity is partially explained by small studies reporting larger effects $(R R=0.71(0.61$ to 0.84$)$ ).

There was some evidence of visual asymmetry on the funnel plot we produced, but the overall effect was strongly influenced by five studies that accounted for over $80 \%$ of the weighted mean; even if the result was influenced by small study bias, the magnitude of the effect was small. To impact the results, missing studies would need to be very large and show no difference or harmful effects, as demonstrated in the third sensitivity analysis.

\section{Design effects in cluster trials}

Known ICCs were remarkably consistent. For three studies for which the ICC was not known, we estimated ICC $=0.002$ and we adjusted SEs using this value and the average cluster size. To determine if this decision had any impact on the results, we repeated the primary analysis using a much larger and much smaller ICC estimate. The size of the effect was slightly smaller when these trials were treated as if they had randomised individuals $(\mathrm{RR}=0.81$ ( $95 \% 0.75$ to 0.89$)$ ). The effect was virtually unchanged when we increased the ICC to $0.01(\mathrm{RR}=0.75(95 \% \mathrm{CI} 0.68$ to 0.83$)$ ), see Table 1. These results indicate that over-weighting these three studies in the analysis would not impact the conclusions of this review; further inflating their SEs would increase the size of the effect estimate.

\section{Studies awaiting assessment}

One study awaiting assessment was added to the analysis (DEVTA 2007). This trial found no significant effect of VAS on mortality $(\mathrm{RR}=0.96(95 \% \mathrm{CI} 0.89$ to 1.03$))$.

In our analysis of 18 trials, DEVTA 2007 accounted for $65.2 \%$ of the combined effect, which remained significant $(\mathrm{RR}=0.88(95 \%$ CI 0.84 to 0.94$)$ ) with substantial and significant heterogeneity $\left(\mathrm{Chi}^{2}=44.31, \mathrm{df}=16(\mathrm{P}=0.0002) ; \mathrm{I}^{2}=64 \%\right)$. (We assumed the study authors adjusted for clustering. As the results were not significant, inflating the SE would not change our interpretation of the trial's results, although it would decrease its weight in the analysis.)

Including DEVTA 2007 decreased the estimated benefit of Vitamin A by half (24\% to $12 \%$ ), but the result remained significant and clinically meaningful. As we were unable to assess the trial, we cannot explain this substantially different result. 


\subsection{Diarrhoea mortality}

Seven trials (Rahmathullah 1990; Daulaire 1992; Herrera 1992; Ross 1993 SURVIVAL; Agarwal 1995; Venkatarao 1996; Chowdhury 2002) reported a combined $28 \%$ reduction in diarrhoea mortality ( $\mathrm{RR}=0.72$ (95\% CI 0.57 to 0.91$)$ ) with no important heterogeneity $\left(\mathrm{Chi}^{2}=6.12, \mathrm{df}=6(\mathrm{P}=0.41) ; \mathrm{I}^{2}=2 \%\right)$, Figure 4.

Figure 4. Forest plot of comparison: I Vitamin A versus Control, outcome: I.5 Mortality due to Diarrhoea at Longest Follow-up.

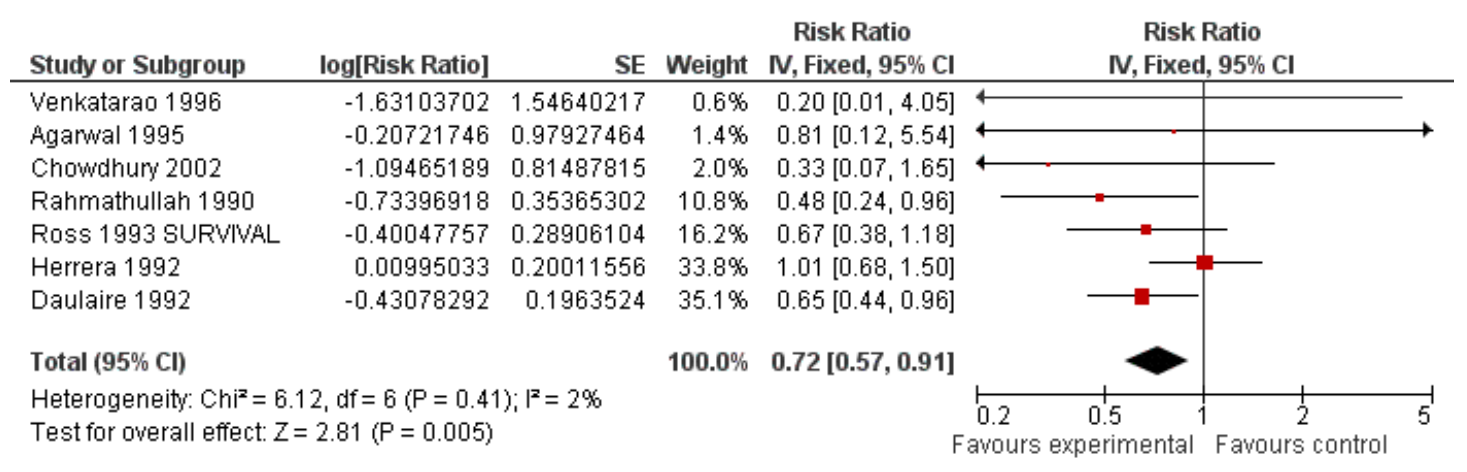

\subsection{Measles mortality}

Five trials (Rahmathullah 1990; Daulaire 1992; Herrera 1992; Ross 1993 SURVIVAL; Agarwal 1995) reported a lower risk of measles mortality, but the effect was not statistically significant $(\mathrm{RR}=0.80(95 \% \mathrm{CI} 0.51$ to 1.24$))$. There was no important heterogeneity $\left(\mathrm{Chi}^{2}=0.40, \mathrm{df}=4(\mathrm{P}=0.98) ; \mathrm{I}^{2}=0 \%\right)$, Figure 5 .

Figure 5. Forest plot of comparison: I Vitamin A versus Control, outcome: I.6 Mortality due to Measles at Longest Follow-up.

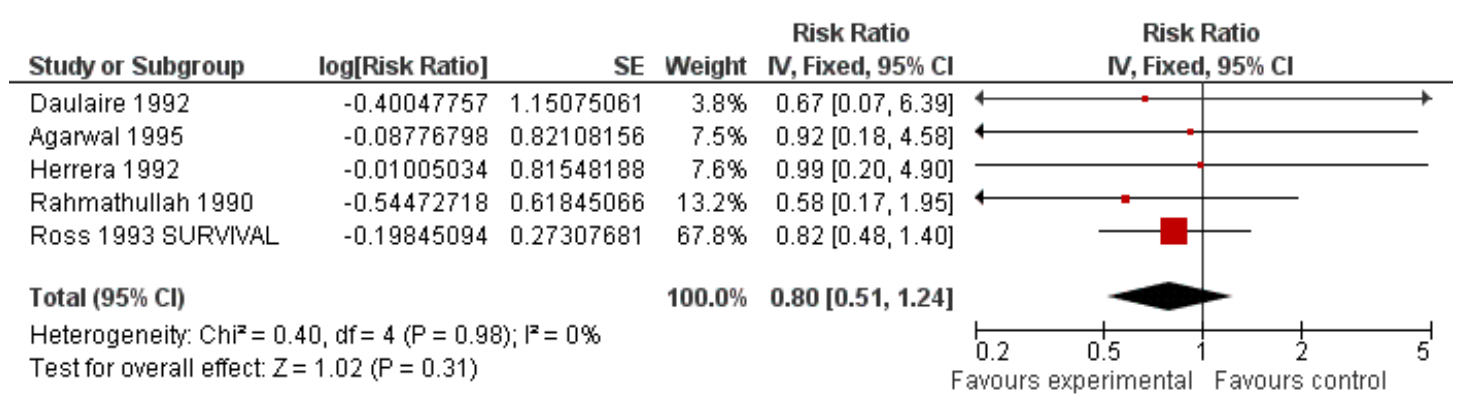

Vitamin A supplementation for preventing morbidity and mortality in children from 6 months to 5 years of age (Review) 


\subsection{Meningitis mortality}

Three trials (Ross 1993 SURVIVAL; Agarwal 1995; Chowdhury 2002) reported a lower risk of meningitis mortality, but the effect was not statistically significant $(\mathrm{RR}=0.57$ (95\% CI 0.17 to 1.88$)$ ). There was no important heterogeneity $\left(\mathrm{Chi}^{2}=0.75, \mathrm{df}=2(\mathrm{P}=\right.$ $\left.0.69) ; \mathrm{I}^{2}=0 \%\right)$.

\subsection{Lower Respiratory Tract Infection (LRTI) mortality}

Seven trials (Rahmathullah 1990; Daulaire 1992; Herrera 1992; Ross 1993 SURVIVAL; Agarwal 1995; Venkatarao 1996;
Chowdhury 2002) reported a lower risk of LRTI mortality, but the effect was not statistically significant $(\mathrm{RR}=0.78$ (95\% CI 0.54 to 1.14$))$. There was no important heterogeneity $\left(\mathrm{Chi}^{2}=7, \mathrm{df}=\right.$ $\left.6(\mathrm{P}=0.32) ; \mathrm{I}^{2}=14 \%\right)$.

\subsection{Diarrhoea}

Thirteen trials (Florentino 1990; Herrera 1992; Cheng 1993; Barreto 1994; Biswas 1994; Dibley 1994; Ramakrishnan 1995; Venkatarao 1996; Sempertegui 1999; Shankar 1999; Arya 2000; Chowdhury 2002; Long 2007) reported an $18 \%$ decrease in diarrhoea incidence $(\mathrm{RR}=0.85$ (95\% CI 0.82 to 0.87$)$ ), though statistical heterogeneity was substantial and highly significant $\left(\mathrm{Chi}^{2}\right.$ $\left.=218.62, \mathrm{df}=11(\mathrm{P}<0.00001) ; \mathrm{I}^{2}=95 \%\right)$, Figure 6 .

Figure 6. Forest plot of comparison: I Vitamin A versus Control, outcome: I.9 Diarrhoea Incidence at Longest Follow-up.

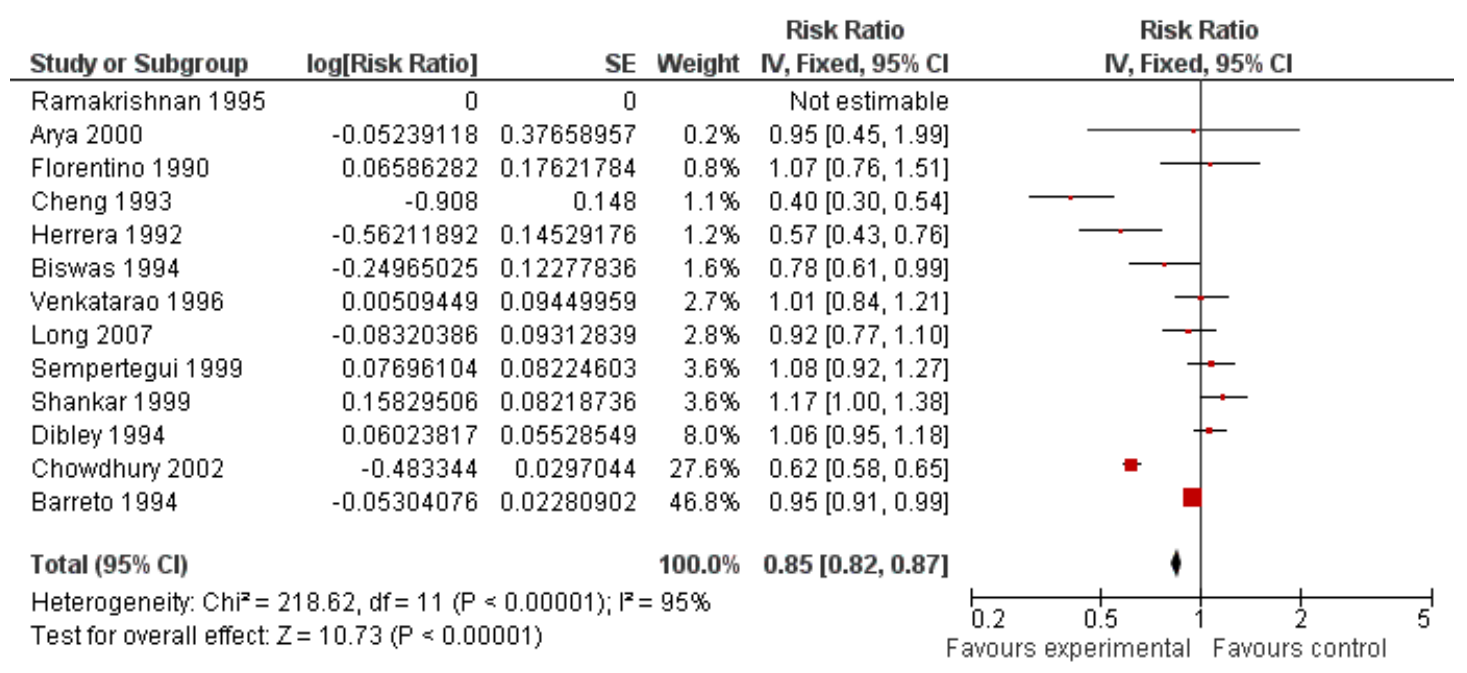

The results of this analysis were highly heterogenous and two studies account for the majority of the overall effect (Cheng 1993; Chowdhury 2002). The observed heterogeneity may be due to measurement error or differences in the effects of VAS across populations and settings. For example, it may reduce susceptibility to particular infections that are prevalent in some places but not others.

Two trials (Stansfield 1993 and Long 2006/Long 2006 (2)) reported no combined effect on diarrhoea prevalence $(\mathrm{RR}=1.08$ (95\% CI 1.05 to 1.12$)$ ) though statistical heterogeneity was substantial and highly significant $\left(\mathrm{Chi}^{2}=15.76, \mathrm{df}=2(\mathrm{P}=0.0004)\right.$; $\left.\mathrm{I}^{2}=87 \%\right)$.

\section{Sensitivity analysis}

\section{Bias}

To test for small study bias, we repeated the analysis using a random-effects model. The overall estimate was identical to the fixedeffect estimate, though the result bordered on statistical significance, suggesting that heterogeneity is not explained by small studies reporting larger effects ( $R R=0.85$ (95\% CI 0.72 to 1.00$)$ ). The funnel plot we produced was dominated by two studies accounting for $74 \%$ of the overall effect, and the plot was relatively flat. 


\section{Design effects in cluster trials}

No ICCs were imputed, so sensitivity analysis was not required.

\subsection{Measles}

Six trials (Herrera 1992; Barreto 1994; Semba 1995; Benn 1997; Bahl 1999; Chowdhury 2002) reported a 50\% decrease in measles incidence ( $\mathrm{RR}=0.50$ (95\% CI 0.37 to 0.67$)$ ) with no important heterogeneity $\left(\mathrm{Chi}^{2}=0.55, \mathrm{df}=5(\mathrm{P}=0.99) ; \mathrm{I}^{2}=0 \%\right)$, Figure 7 .

Figure 7. Forest plot of comparison: I Vitamin A versus Control, outcome: I.I2 Measles Incidence at Longest Follow-up.

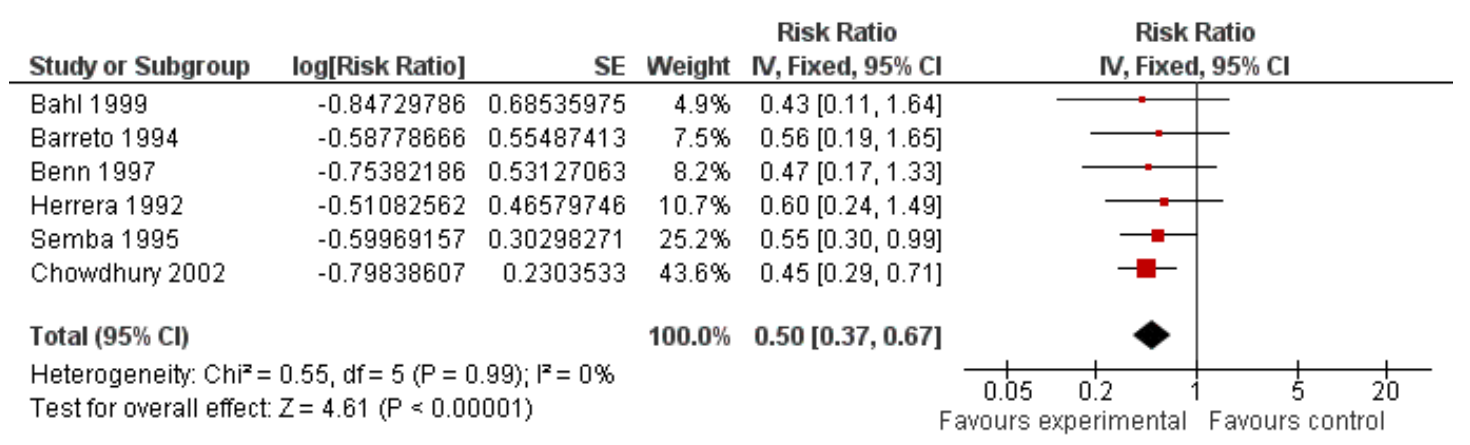

No trials reported data on measles prevalence that could be analysed at follow-up.

\subsection{Malaria}

One trial (Shankar 1999) reported a $27 \%$ reduction in malaria incidence $(\mathrm{RR}=0.73$ (95\% CI 0.60 to 0.88$)$ ).

Two trials (Ross 1993 HEALTH; Ross 1993 SURVIVAL) reported data on malaria prevalence; the combined effect was not statistically significant $(\mathrm{RR}=0.72(0.42$ to 1.23$))$ and there was no important heterogeneity $\left(\mathrm{Chi}^{2}=0.03, \mathrm{df}=1(\mathrm{P}=0.87) ; \mathrm{I}^{2}=0 \%\right)$. Only one study reported data on malaria prevalence that could be analysed at follow- up, the results of which were not significant $(\mathrm{RR}=0.73$ (0.41 to 1.28$)$ ).

\subsection{Meningitis}

No trials reported data on meningitis incidence or prevalence that could be analysed at follow-up.

\subsection{Lower Respitatory Tract Infection}

Nine trials (Rahmathullah 1990; Cheng 1993; Barreto 1994; Biswas 1994; Kartasasmita 1995; Venkatarao 1996; Sempertegui
1999; Chowdhury 2002; Long 2007) reported no combined effect on LRTI incidence $(\mathrm{RR}=1.14(0.95$ to 1.37$))$ with no important heterogeneity $\left(\mathrm{Chi}^{2}=7.66, \mathrm{df}=6(\mathrm{P}=0.26) ; \mathrm{I}^{2}=22 \%\right)$. LRT prevalence was reported in a factorial trial (Long 2006) with two relevant comparisons; the combined result of which was inconclusive but suggests benefit ( $R R=0.46(95 \%$ CI 0.21 to 1.03$)$ ).

\section{I.0 Vision}

\section{I.I Bitot's spots}

One trial (Herrera 1992) reported no effect on Bitot's spots incidence $(\mathrm{RR}=0.93$ (95\% CI 0.76 to 1.14$)$ ).

Four trials (Sinha 1976; Sommer 1986; West 1991; Pant 1996) reported a $53 \%$ reduction in Bitot's spots prevalence $(R R=0.45$ ( $95 \%$ CI 0.33 to 0.61$)$ ) with substantial and significant heterogeneity $\left(\mathrm{Chi}^{2}=8.25, \mathrm{df}=3(\mathrm{P}=0.04) ; \mathrm{I}^{2}=64 \%\right)$.

\section{I.2 Night blindness}

One trial (Herrera 1992) reported a $47 \%$ reduction in night blindness incidence ( $R R=0.53$ (95\% CI 0.28 to 0.99$)$ ). 
Two trials (Sommer 1986; West 1991) reported a 68\% reduction night blindness prevalence $(\mathrm{RR}=0.32(95 \% \mathrm{CI} 0.21$ to 0.50$)$ ) with no heterogeneity $\left(\mathrm{Chi}^{2}=0.19, \mathrm{df}=1(\mathrm{P}=0.66) ; \mathrm{I}^{2}=0 \%\right)$.

\section{I.3 Xerophthalmia}

Three trials (West 1991; Herrera 1992; Barreto 1994) reported no combined effect on xerophthalmia incidence $(\mathrm{RR}=0.85(95 \%$ CI 0.70 to 1.03$)$ ), though statistical heterogeneity was substantial and significant $\left(\mathrm{Chi}^{2}=2.69, \mathrm{df}=1(\mathrm{P}=0.10) ; \mathrm{I}^{2}=63 \%\right)$.

Two trials (Sommer 1986; West 1991) reported a 69\% reduction in xerophthalmia prevalence $(\mathrm{RR}=0.31(95 \% \mathrm{CI} 0.22$ to 0.45$)$ ) with no statistical heterogeneity $\left(\mathrm{Chi}^{2}=0.22, \mathrm{df}=1(\mathrm{P}=0.64)\right.$; $\left.\mathrm{I}^{2}=0 \%\right)$.

\subsection{Vitamin A deficiency}

\section{I Number deficient}

Four trials (Ross 1993 HEALTH; Dibley 1994; Shankar 1999; Ranjini 2001) reported a $29 \%$ reduction in the number of VAD children $(\mathrm{RR}=0.71(95 \% \mathrm{CI} 0.65$ to 0.78$)$ ); however, statistical heterogeneity was substantial and significant $\left(\mathrm{Chi}^{2}=13.58, \mathrm{df}=\right.$ $\left.3(\mathrm{P}=0.004) ; \mathrm{I}^{2}=78 \%\right)$.

\section{2.2 Serum level}

Thirteen studies (Pinnock 1986; Reddy 1986; Pinnock 1988; Semba 1992; Cheng 1993; Ross 1993 HEALTH; Ross 1993 SURVIVAL; Dibley 1994; Kartasasmita 1995; Sempertegui 1999; Shankar 1999; Ranjini 2001; Lin 2009) reported vitamin A serum data at follow- up, including one factorial study contributing two comparisons. Vitamin A serum levels were higher in the Vitamin A group (SMD $=0.31$ (95\% CI 0.26 to 0.36$)$ ), however statistical heterogeneity was substantial and significant $\left(\mathrm{Chi}^{2}=270.23, \mathrm{df}=\right.$ $\left.13(\mathrm{P}<0.00001) ; \mathrm{I}^{2}=95 \%\right)$.

\section{Sensitivity analysis}

\section{Bias}

No studies in this outcome were at high risk of bias for sequence generation.

To test for small study bias, we repeated the analysis using a random-effects model. The overall estimate was considerably larger than the fixed-effect estimate, suggesting small studies report larger effects ( $R R=0.53$ (95\% CI 0.27 to 0.79$)$ ).

The funnel plot that we produced was highly asymmetrical.

\section{Design effects in cluster trials}

No ICCs were imputed, so sensitivity analysis was not required.

\subsection{Hospitalisation}

One trial (Ross 1993 HEALTH) reported a reduction of the likelihood of hospitalisations that approached statistical significance $(\mathrm{RR}=0.64(95 \% \mathrm{CI} 0.40$ to 1.02$))$ and a $38 \%$ reduction in the number of hospitalisations ( $\mathrm{RR}=0.62$ (95\% CI 0.42 to 0.93$)$ ). One trial (Cheng 1993) reported inconclusive evidence on diarrhoea related hospitalisation ( $\mathrm{RR}=0.25$ (95\% CI 0.01 to 6.11$)$ ). One trial (Cheng 1993) reported inconclusive evidence on LRTI hospitalisation $(\mathrm{RR}=0.11$ (95\% CI 0.01 to 2.06$)$ ).

\subsection{Side effects}

We assessed two short-term side effects:

\section{I4.I Vomiting (within 48 hours)}

Three trials (Sinha 1976; Florentino 1990; Arya 2000) reported a significant increase in risk of vomiting $(\mathrm{RR}=2.75(95 \% \mathrm{CI} 1.81$ to 4.19)) with statistical heterogeneity that was not important $\left(\mathrm{Chi}^{2}\right.$ $\left.=2.53, \mathrm{df}=2(\mathrm{P}=0.28) ; \mathrm{I}^{2}=21 \%\right)$. Immediately following the intervention, the rate of vomiting increased from $2 \%$ to $6 \%$.

\subsection{Fontanelle}

Three trials (Stabell 1995; Bahl 1999; Arya 2000) reported fontanelle side effects, but only one could be analysed because the others reported insufficient data, which reported no effect $(\mathrm{RR}=$ 5.00 (95\% CI 0.24 to 103.72)). Most studies included children over 1 year old and would not have assessed this side effect. Results not contained in the Data and Analyses section are listed below in Table 1.

\section{DISCUSSION}

\section{Summary of main results}

Vitamin A supplementation appeared to reduce all-cause mortality by $24 \%$. There was some statistical heterogeneity in the pooled data.

Much of the reduction in all-cause mortality is explained by reductions in death due to diarrhoea and measles, although many of the cause-specific mortality and morbidity outcomes were characterised by uncertainty. The overall effect for measles mortality was not significant, but the trend was consistent with the overall results and the therapeutic effects of VAS in reducing measles related mortality and morbidity are well established (Yang 2009). 
Furthermore, VAS resulted in a reduced incidence of diarrhoea and measles. Other reviews have shown that the therapeutic use of VAD may prevent acute diarrhoea from becoming chronic (Imdad 2010). Together, these results suggest that reductions in diarrhoea and measles are potential pathways in the reduction of all-cause mortality.

In addition to reducing death and illness, VAS reduces night blindness and potential precursors to blindness, namely Bitot's spots and xerophthalmia.

Some authors hypothesise that the preventive effect of VAS against infections is related to increased responsiveness to vaccines given around these times, especially in infants (Benn 2003). This has been recently challenged (Kirkwood 2010) and a meta-regression of studies does support the direction of overall effect (Rotondi 2010). A more detailed discussion about this hypothesis is available in the review on neonatal VAS by our group (Haider 2008).

The current review did not locate any trials that compare different co-interventions; policy makers and practitioners should use other types of studies to assess how the delivery and responsiveness to vitamin A might relate to other nutritional and health interventions.

Few studies reported data about side effects, including vomiting, bulging fontanelle and diarrhoea soon after receiving the intervention. VAS may increase short-term vomiting by $4 \%$.

\section{Overall completeness and applicability of evidence}

This is the first published review to assess systematically both mortality and morbidity associated with VAS. Other outcomes relevant to VAS, including stunting, could be added to future versions, but few studies have measured these effects. Nonetheless, observed effects on morbidity suggest that vitamin A may improve overall health, and observational studies might examine the nature of this relationship.

All included studies reporting all-cause mortality were conducted in developing countries. The results appear applicable to developing countries with chronic VAD. The primary analysis is based on many large trials from several countries and locations. It included $90 \%$ of the children randomised in this review; risk of selective outcome reporting appears minimal. Statistical heterogeneity suggests that the magnitude of the effect may differ across settings and populations, possibly due to the extent of VAD or the availability of other nutrients. For example, dietary intake of vitamin A will differ across locations and the effects of supplementation may be smaller in places with greater access to vitamin A rich food. Concomitant nutrient deficiencies may also impair the bioavailability of the supplements, since some of these nutrients (including fat, protein and zinc) could be limiting factors for the absorption and utilisation of vitamin A, which is lipid-soluble (Villamor 2000). Comorbid illnesses could also reduce absorption of Vitamin A. That is, if vitamin A reduces mortality by reducing susceptibility to particular pathogens, differences in the prevalence of disease, sanitation, etc. might contribute to heterogeneity in outcomes across trials. Future versions of this review might investigate if VAS reduces both mild and severe episodes of diarrhoea, as the latter are more closely linked to mortality. A few trials have measured malaria mortality, which was not included in the review protocol; this outcome should be added to future versions of the review. All included studies reporting all-cause mortality were conducted in low- and middle-income countries. The results appear applicable to all such countries with chronic VAD.

Analyses for many of the cause-specific mortality and morbidity outcomes were consistent. A general weakness of many interventions is the underreporting of implementation data, such as the core components of an intervention, the degree to which they are delivered in practice, and what aspects of the trial may have influenced implementation (Mayo-Wilson 2007). In theory, the putative effect of this intervention relies little on the relationship between the provider and participant (discussed previously in the context of performance bias), but it is essential that large-scale interventions effectively distribute capsules that have been stored properly and remain active. Additionally, the degree to which children were treated for morbidities across trials might influence incidence and prevalence data collected in various trials, and this could contribute to heterogeneity.

Some readers will undoubtedly find these results unsatisfying, particularly because the review does not explain heterogeneity in the results. This review suggests some ways in which vitamin A might work, but it does not describe how effects of vitamin A might differ across subpopulations because trials did not report the data required for such analyses. We decided a priori not to include subgroup analyses based on individual-level moderators for reasons described above; we could not have done much more using studylevel data. Co-interventions including other nutrients or vaccinations might interact with vitamin $\mathrm{A}$, but we were unable to review possible interaction effects. We were also unable to compare HIV positive children to HIV negative children. Subgroup analyses by geographical region include few studies; a few studies disaggregated data by gender and age, but these were not representative of the studies overall and the results. Subgroup results were neither significant nor meaningful, and they are vulnerable to reporting bias (i.e. differences are more likely to be reported than similarities). Though a review with individual patient data could be informative, systematic reviews are not the best method for answering all questions, and other studies might explain why results are sometimes different. Furthermore, the observed effects are so large that heterogeneity may be considered unimportant; vitamin A should be given to children whether it reduces childhood mortality by $5 \%$ or $25 \%$.

\section{Quality of the evidence}


The review included 43 studies and an estimated 215,633 children. This is the largest review of VAS for children to date.

The primary outcome was at low risk of bias, and the size and the significance of the effect cannot be explained by bias. While there was some evidence of small study bias for secondary outcomes, further research is unlikely to change the conclusion that VAS, delivered with high quality and coverage, prevents death among children aged 6 to 59 months in the developing world. Despite sensitivity analyses and attempts to explain sources of heterogeneity by comparing the characteristics of the studies, we could not explain reasons for these differences across trials. Observational studies might investigate the mechanisms by which vitamin A reduces mortality.

The DEVTA trial 2007, which includes more than four times the number of children in this review, found no benefit for vitamin A supplementation. However, details that might explain this difference were not available. It is possible that these relatively smaller studies were more prone to bias, but the reviewers find this explanation unlikely to explain the effect in its entirety. When the mortality data for DEVTA trial 2007 are included in the main analysis of this review, a statistically significant benefit for vitamin $A$ is still observed, and that effect remains clinically meaningful.

\section{Potential biases in the review process}

This review used clearly specified inclusion and exclusion criteria, a comprehensive search strategy for the identification of relevant studies, and subgroup and sensitivity analyses to explore heterogeneity that were specified a priori. Post-hoc decisions to include quasi-randomised trials and post-hoc analyses are noted, and sensitivity analyses demonstrate that these did not change the results. The comprehensive search strategy was devised to minimise publication bias by searching for both published and unpublished studies, though none of the included studies were unpublished. While studies with positive results are more likely to be published than studies with negative results, studies large enough to make a difference in this review are very likely to be published. One study awaiting assessment is likely to be published soon (DEVTA trial 2007), and another was too small to affect any analysis (Aklamati 2006). The inclusion of DEVTA in a sensitivity analysis reduces the threat of publication bias and provides evidence that the main finding is robust.

Some secondary outcomes did not contain a majority of the children randomised in the review, and these results may be vulnerable to selective outcome reporting bias.

\section{Agreements and disagreements with other studies or reviews}

These results are consistent with the results of other reviews assessing a similar question, though the magnitude of the reduction in risk of death was smaller. Glasziou 1993 reported a 30\% reduction in all-cause mortality; Beaton 1993, a 23\% reduction, and Fawzi 1993 used an odds ratio rather than risk ratio as the effect statistic so the reported reduction is not directly comparable.

This review contributes a timely update to the status of the evidence; most previous meta-analyses were conducted before publication of the trials contributing $30 \%$ of randomised children in the primary analysis. This effect was explored in a post-hoc cumulative meta-analysis which sorted the included trials by year. As reported in Beaton 1993, there was a 23\% reduction in all-cause mortality by 1993 ( $R R=0.77$ ( $95 \%$ CI 0.70 to 0.85$)$ ). The trials that occurred after 1993 change the effect by only $1 \%$.

\section{A U THORS'CONCLUSIONS}

\section{Implications for practice}

National and regional programmes of VAS are in place in over 70 countries worldwide and may be among the most cost-effective public health interventions (Fawzi 2006). Worldwide, more than 190 million children are vitamin A deficient; reducing their risk of mortality by $24 \%$ could save almost 1 million lives per year. These interventions respond to an immediate need for adequate nutrition, but they are not ideal long-term solutions to the underlying problem.

Fortification, food distribution programs and horticultural developments may provide more permanent relief. For example, vitamin A could be added to rice or growers may aim to increase access to agricultural products such as the orange-fleshed sweet potato (Klemm 2010). Furthermore, if vitamin A reduces mortality by preventing measles, widespread vaccination will reduce the relative contribution of vitamin A supplementation. Until such longterm solutions are in place, supplementation should continue. As access to vitamin $\mathrm{A}$ increases, it will be important to continue to identify at-risk groups and deliver supplements to them.

We strongly recommend vitamin A supplementation to children under 5 in areas at risk of VAD. The exact nature of how these programs should be structured and administered - the dose, frequency, and duration of intervention - are less certain. As discussed above, data on implementation for the trials included in this review (and more generally) are lacking. In the absence of this information, concrete recommendations for practice would be speculative at best. Comparative trials may be informative and policymakers should consider including such trials in plans for vitamin A distribution.

\section{Implications for research}

The effectiveness of VAS for preventing mortality is well-established. The primary result in this review is not meaningfully dif- 
ferent from the results of reviews conducted in 1993. Not all studies conducted in the interim were required, and further placebocontrolled studies would be unethical.

Nevertheless, this review does not answer a number of important questions. There was little variation in dosing among studies reporting the primary outcome. One trial used weekly doses and estimated a $54 \%$ reduction in all-cause mortality (Rahmathullah 1990). It would be ethical to conduct trials in which participants receive different doses of vitamin A that are likely to be beneficial, some of which could lead to larger benefits than those observed so far, and might lead to fewer side effects (for example, vomiting).

Reductions in mortality are likely related to reduced incidence and severity of diarrhoea. The effects of VAS on relevant pathogens and disease pathways are not well understood, and these could be examined in observational studies or in trials of other interventions for these problems.

Growth and other developmental outcomes are less important than mortality and have been studied rarely. These outcomes could be added to future versions of this review. Observational studies might elucidate the relationship (if any), between vitamin A and growth.

Despite the primary effect, observed increases in vitamin A serum levels were small, and serum results are more vulnerable to bias than the overall results. Serum level may be a poor indicator of status, and may not be related to more meaningful outcomes like mortality and blindness. On the other hand, oral supplementation may not be the best pathway for delivery. For example, absorption may be better in protein carriers compared to carbohydrate carri- ers. Further studies might compare synthetic supplementation to fortification or other delivery mechanisms.

Two additional Cochrane reviews have recently investigated the effects of vitamin A during the neonatal period (Haider 2008) and for infants 1 to 6 months of age (Gogia 2008) and will be available shortly. Further reviews might investigate different delivery channels, including food supplementation, improved access to food, or social programmes to increase uptake of vitamin A rich foods. Several studies have investigated VAS for pregnant and lactating mothers; these and other efforts to promote delivery of vitamin A (for example, by increased rates and duration of breastfeeding) may require further attention.

\section{ACKNOW LEDGEMENTS}

We thank the Cochrane Developmental Psychosocial and Learning Problems Group, including Jo Abbott, Chris Champion and Laura MacDonald. Particularly, Margaret Anderson developed the search strategy and Geraldine Macdonald edited the review. We thank the Cochrane Editorial Unit, particularly Toby Lasserson, Rachel Murphy, and Karla Soares-Weiser for extracting data; we thank David Tovey and Harriet MacLehose for advice and for helping to manage the project. We are also grateful to Toby Lasserson for drafting the summary of findings table. Henry Ebron from DistillerSR provided assistance managing the data. We thank Julian Higgins and the Cochrane Methods Group for statistical advice and assistance. Finally, anonymous peer reviewers offered helpful feedback on the protocol and the review.

\section{R E F E R E N C E S}

\section{References to studies included in this review}

Agarwal 1995 \{published data only\}

Agarwal DK, Pandey CM, Agarwal KN. Vitamin A administration and preschool child mortality. Nutrition Research. Nutrition Research. 15(5)(pp 669-680), 1995. Date of Publication: 1995., 1995; Vol. 15, issue 5:669-80. [0271-5317]

Arya 2000 \{published data only\}

Arya S, Chellani H, Pandey J. Evaluation of safety of oral vitamin 'A' megadose co-administered with measles vaccination. Indian Pediatrics. 2000/12/19 2000; Vol. 37, issue 12:1341-7. [0019-6061: (Print)]

Bahl 1999 \{published data only\}

Bahl R, Kumar R, Bhandari N, Kant S, Srivastava R, Bhan MK. Vitamin A administered with measles vaccine to ninemonth-old infants does not reduce vaccine immunogenicity. Journal of Nutrition 1999; Vol. 129, issue 8:1569-73. [0022-3166]

\section{Barreto 1994 \{published data only\}}

Andreozzi VL, Bailey TC, Nobre FF, Struchiner CJ, Barreto ML, Assis AM, et al. Random-effects models in investigating the effect of vitamin A in childhood diarrhea. Annals of Epidemiology 2006; Vol. 16, issue 4:241-7. [1047-2797]

* Barreto ML, Santos LM, Assis AM, Araujo MP, Farenzena GG, Santos PA, et al. Effect of vitamin A supplementation on diarrhoea and acute lower-respiratory-tract infections in young children in Brazil. Lancet 1994; Vol. 344, issue 8917:228-31. [0140-6736]

Benn 1997 \{published data only\}

* Benn CS, Aaby P, Bale C, Olsen J, Michaelsen KF, George E, et al. Randomised trial of effect of vitamin A supplementation on antibody response to measles vaccine in Guinea-Bissau, west Africa. Lancet 1997; Vol. 350, issue 9071:101-5. [0140-6736]

Benn CS, Lisse IM, Bale C, Michaelsen KF, Olsen J, Hedegaard K, et al. No strong long-term effect of vitamin 
A supplementation in infancy on CD4 and CD8 T-cell subsets. A community study from Guinea-Bissau, West Africa. Annals of Tropical Paediatrics 2000; Vol. 20, issue 4:259-64. [0272-4936]

\section{Biswas 1994 \{published data only\}}

Biswas R, Biswas AB, Manna B, Bhattacharya SK, Dey R, Sarkar $S$. Effect of vitamin A supplementation on diarrhoea and acute respiratory tract infection in children. A double blind placebo controlled trial in a Calcutta slum community. European Journal of Epidemiology 1994, issue 1:57-61.

Cheng 1993 \{published data only\}

Cheng L, Chang Y, Wang EL, Brun T, Geissler C. Impact of large-dose vitamin A supplementation on childhood diarrhoea, respiratory disease and growth. European Journal of Clinical Nutrition 1993; Vol. 47, issue 2:88-96. [0954-3007]

\section{Cherian 2003 \{published data only\}}

Cherian T, Sneha V, Raghupathy P, Ratnam S, Chandra RK. Effect of vitamin A supplementation on the immune response to measles vaccination. Vaccine 2003; Vol. 21, issue 19:2418-20. [0264-410X]

Chowdhury 2002 \{published data only\}

Chowdhury S, Kumar R, Ganguly NK, Kumar L, Walia BN. Effect of vitamin A supplementation on childhood morbidity and mortality. Indian Journal of Medical Sciences 2002, issue 6:259-64.

\section{Daulaire 1992 \{published data only\}}

Daulaire NM, Starbuck ES, Houston RM, Church MS, Stukel TA, Pandey MR. Childhood mortality after a high dose of vitamin A in a high risk population. BMJ 1992; Vol. 304, issue 6821:207-10. [0959-8138]

DEVTA 2007 \{published data only\}

See Studies awaiting classification.

Dibley 1994 \{published data only\}

* Dibley MJ, Sadjimin T, Kjolhede CL, Moulton LH. Vitamin A supplementation fails to reduce incidence of acute respiratory illness and diarrhea in preschool-age Indonesian children. Journal of Nutrition 1996; Vol. 126, issue 2:434-42. [0022-3166]

Hadi H, Dibley MJ, West KP. Complex interactions with infection and diet may explain seasonal growth responses to vitamin A in preschool aged Indonesian children. European Journal of Clinical Nutrition 2004, issue 7:990-9. Hadi H, Stoltzfus RJ, Dibley MJ, Moulton LH, West KP Jr, Kjolhede CL, et al. Vitamin A supplementation selectively improves the linear growth of Indonesian preschool children: results from a randomized controlled trial. American Journal of Clinical Nutrition 2000; Vol. 71 , issue 2:507-13. [0002-9165]

Hadi H, Stoltzfus RJ, Moulton LH, Dibley MJ, West KP Jr. Respiratory infections reduce the growth response to vitamin A supplementation in a randomized controlled trial. International Journal of Epidemiology 1999; Vol. 28, issue 5:874-81. [0300-5771]
Donnen 1998 \{published data only\}

Donnen P, Brasseur D, Dramaix M, Vertongen F, Zihindula M, Muhamiriza M, et al. Vitamin A supplementation but not deworming improves growth of malnourished preschool children in eastern Zaire. Journal of Nutrition 1998; Vol. 128, issue 8:1320-7. [0022-3166]

* Donnen P, Dramaix M, Brasseur D, Zihindula M, Muhamiriza M, Hennart P. Malnourished children morbidity following vitamin A supplementation or deworming in Democratic Republic of Congo. Archives of Public Health 1998; Vol. 56, issue 3:109-24. [0003-9578]

Florentino 1990 \{published data only\}

Florentino RF, Tanchoco CC, Ramos AC, Mendoza TS, Natividad EP, Tangco JB, et al. Tolerance of preschoolers to two dosage strengths of vitamin A preparation. American Journal of Clinical Nutrition 1990; Vol. 52, issue 4: 694-700. [0002-9165]

\section{Herrera 1992 \{published data only\}} Fawzi WW, Herrera MG, Willett WC, Nestel P, el Amin A, Lipsitz S, et al. Dietary vitamin A intake and the risk of mortality among children. American Journal of Clinical Nutrition 1994; Vol. 59, issue 2:401-8. [0002-9165] Fawzi WW, Herrera MG, Willett WC, Nestel P, el Amin A, Mohamed KA. Dietary vitamin A intake and the incidence of diarrhea and respiratory infection among Sudanese children. Journal of Nutrition. 1995/05/01 1995; Vol. 125, issue 5:1211-21. [0022-3166: (Print)]

Fawzi WW, Herrera MG, Willett WC, Nestel P, el Amin A, Mohamed KA. The effect of vitamin A supplementation on the growth of preschool children in the Sudan. American Journal of Public Health 1997; Vol. 87, issue 8:1359-62. [0090-0036]

Fawzi WW, Herrera MG, Willett WC, el Amin A, Nestel P, Lipsitz S, et al. Vitamin A supplementation and dietary vitamin $A$ in relation to the risk of xerophthalmia. American Journal of Clinical Nutrition. American Journal of Clinical Nutrition. 58(3)(pp 385-391), 1993. Date of Publication: 1993., 1993; Vol. 58, issue 3:385-91. [0002-9165]

* Herrera MG, Nestel P, el Amin A, Fawzi WW, Mohamed KA, Weld L. Vitamin A supplementation and child survival. Lancet 1992; Vol. 340, issue 8814:267-71. [0140-6736]

\section{Kartasasmita 1995 \{published data only\}}

Kartasasmita CB, Rosmayudi O, Deville W, Demedts M. Plasma retinol level, vitamin A supplementation and acute respiratory infections in children of 1-5 years old in a developing country. Tubercle and Lung Disease 1995; Vol. 76, issue 6:563-9. [0962-8479]

\section{Lima 2010 \{published data only\}} Lima AA, Soares AM, Lima NL, Mota RM, Maciel BL, Kvalsund MP, et al. Effects of vitamin A supplementation on intestinal barrier function, growth, total parasitic, and specific Giardia spp infections in Brazilian children: a prospective randomized, double-blind, placebo-controlled trial. Journal of Pediatric Gastroenterology \& Nutrition 2010; Vol. 50, issue 3:309-15. 
Lin 2008 \{published data only\}

Lin J, Song F, Yao P, Yang X, Li N, Sun S, et al. Effect of vitamin A supplementation on immune function of wellnourished children suffering from vitamin A deficiency in China. European Journal of Clinical Nutrition 2008, issue 12:1412-8.

Lin 2009 \{published data only\}

Lin J, Lai X, Qin J, Song F, Zhang Y, Yao P, et al. Effect of beta-carotene supplementation on health and growth of vitamin A deficient children in China rural villages: A randomized controlled trial. e-SPEN, the European e-Journal of Clinical Nutrition and Metabolism 2009;4(1):e17-e21. [1751-4991]

Long 2006 \{published data only\}

${ }^{*}$ Long KZ, Montoya Y, Hertzmark E, Santos JI, Rosado JL. A double-blind, randomized, clinical trial of the effect of vitamin $A$ and zinc supplementation on diarrheal disease and respiratory tract infections in children in Mexico City, Mexico. American Journal of Clinical Nutrition 2006; Vol. 83, issue 3:693-700. [0002-9165]

Rosado JL, Caamano MC, Montoya YA, Solano MdL, Santos JI, Long KZ. Interaction of zinc or vitamin A supplementation and specific parasite infections on Mexican infants' growth: a randomized clinical trial. European Journal of Clinical Nutrition 2009; Vol. 63, issue 10: 1176-84. [0954-3007]

Long 2006 (2) \{published data only\} As above.

Long 2007 \{published data only\}

Long KZ, Estrada-Garcia T, Rosado JL, Santos JI, Haas M, Firestone $\mathrm{M}$, et al. The effect of vitamin A supplementation on the intestinal immune response in Mexican children is modified by pathogen infections and diarrhea. Journal of Nutrition 2006; Vol. 136, issue 5:1365-70. [0022-3166]

* Long KZ, Rosado JL, DuPont HL, Hertzmark E, Santos JI. Supplementation with vitamin A reduces watery diarrhoea and respiratory infections in Mexican children. British Journal of Nutrition 2007; Vol. 97, issue 2:337-43. [0007-1145]

Long KZ, Santos JI, Rosado JL, Lopez-Saucedo C, Thompson-Bonilla R, Abonce M, et al. Impact of vitamin A on selected gastrointestinal pathogen infections and associated diarrheal episodes among children in Mexico City, Mexico. Journal of Infectious Diseases 2006; Vol. 194, issue 9:1217-25. [0022-1899]

Pant 1996 \{published data only\}

* Pant CR, Pokharel GP, Curtale F, Pokhrel RP, Grosse RN, Lepkowski J, et al. Impact of nutrition education and megadose vitamin A supplementation on the health of children in Nepal. Bulletin of the World Health Organization 1996; Vol. 74, issue 5:533-45. [0042-9686]

Pokharel GP, Pant CR, Tilden RL, Pokhrel RP, Atmarita, Curtale F. Nutrition education and mega-dose vitamin A supplementation in Nepal. Indian Journal of Pediatrics 1998; Vol. 65, issue 4:547-55. [0019-5456]
Pinnock 1986 \{published data only\}

Pinnock CB, Douglas RM, Badcock NR. Vitamin A status in children who are prone to respiratory tract infections. Australian Paediatric Journal. 1986/05/01 1986; Vol. 22, issue 2:95-9. [0004-993X: (Print)]

Pinnock 1988 \{published data only\}

Pinnock CB, Douglas RM, Martin AJ, Badcock NR. Vitamin A status of children with a history of respiratory syncytial virus infection in infancy. Australian Paediatric Journal. 1988/10/01 1988; Vol. 24, issue 5:286-9. [0004-993X: (Print)]

Rahman 2001 \{published data only\} Rahman MM, Fahmida T, Wahed MA, Fuchs GJ, Baqui $\mathrm{AH}$, Alvarez JO. Short-term supplementation with zinc and vitamin A has no significant effect on the growth of undernourished Bangladeshi children. American Journal of Clinical Nutrition 2002; Vol. 75, issue 1:87-91. [0002-9165]

* Rahman MM, Vermund SH, Wahed MA, Fuchs GJ, Baqui AH, Alvarez JO. Simultaneous zinc and vitamin A supplementation in Bangladeshi children: randomised double blind controlled trial. BMJ 2001; Vol. 323, issue 7308:314-8. [0959-8138]

Rahman MM, Wahed MA, Fuchs GJ, Baqui AH, Alvarez JO. Synergistic effect of zinc and vitamin $A$ on the biochemical indexes of vitamin A nutrition in children. American Journal of Clinical Nutrition 2002; Vol. 75, issue 1:92-8. [0002-9165]

Rahmathullah 1990 \{published data only\}

Rahmathullah L. Effect of receiving a weekly dose of vitamin A equivalent to the recommended dietary allowances among pre school children on mortality in south India. Indian Journal of Pediatrics 1991, issue 6:837-47.

Rahmathullah L, Underwood BA, Thulasiraj RD, Milton RC. Diarrhea, respiratory infections, and growth are not affected by a weekly low-dose vitamin A supplement: a masked, controlled field trial in children in southern India. American Journal of Clinical Nutrition 1991; Vol. 54, issue 3:568-77. [0002-9165]

* Rahmathullah L, Underwood BA, Thulasiraj RD, Milton RC, Ramaswamy K, Rahmathullah R, et al. Reduced mortality among children in southern India receiving a small weekly dose of vitamin A. New England Journal of Medicine 1990; Vol. 323, issue 14:929-35. [0028-4793] Rahmathullah L, Underwood BA, Thulasiraj RD, Milton RC, Ramaswamy K, Rahmathullah R, et al. Vitamin a supplementation reduces childhood mortality. National Medical Journal of India 1991; Vol. 4, issue 4:187-9.

Ramakrishnan 1995 \{published data only\} Ramakrishnan U, Latham MC, Abel R. Vitamin A supplementation does not improve growth of preschool children: a randomized, double-blind field trial in south India. Journal of Nutrition 1995; Vol. 125, issue 2:202-11. [0022-3166]

* Ramakrishnan U, Latham MC, Abel R, Frongillo EA Jr. Vitamin A supplementation and morbidity among preschool children in South India. American Journal of 
Clinical Nutrition 1995; Vol. 61, issue 6:1295-303. [0002-9165]

\section{Ranjini 2001 \{published data only\}}

Ranjini EK, Cherian T, Balasubramaniam KA, Raghupathy P. Vitamin A supplementation in children with recurrent respiratory infections. Indian Pediatrics 2001; Vol. 38, issue 7:771-4. [0019-6061]

Reddy 1986 \{published data only\}

Reddy V, Vijayaraghavan K, Mathur KK. Effect of deworming and vitamin A administration on serum vitamin A levels in preschool children. Journal of Tropical Pediatrics 1986; Vol. 32, issue 4:196-9. [0142-6338]

Reddy 1986 (2) \{published data only\} As above.

Ross 1993 HEALTH \{published data only\}

Benn CS, Aaby P, Nielsen J, Binka FN, Ross DA. Does vitamin A supplementation interact with routine vaccinations? An analysis of the Ghana Vitamin A Supplementation Trial. American Journal of Clinical Nutrition 2009; Vol. 90, issue 3:629-39.

Binka FN, Ross DA, Morris SS, Kirkwood BR, Arthur P, Dollimore N, et al. Vitamin A supplementation and childhood malaria in northern Ghana. American Journal of Clinical Nutrition 1995; Vol. 61, issue 4:853-9. [0002-9165]

Dollimore N, Cutts F, Binka FN, Ross DA, Morris SS, Smith PG. Measles incidence, case fatality, and delayed mortality in children with or without vitamin A supplementation in rural Ghana. American Journal of Epidemiology 1997; Vol. 146, issue 8:646-54. [0002-9262]

Filteau SM, Morris SS, Raynes JG, Arthur P, Ross DA, Kirkwood BR, et al. Vitamin A supplementation, morbidity, and serum acute-phase proteins in young Ghanaian children. American Journal of Clinical Nutrition 1995; Vol. 62, issue 2:434-8. [0002-9165]

Filteau SM, Morris SS, Tomkins AM, Arthur P, Kirkwood $\mathrm{BR}$, Ross DA, et al. Lack of association between vitamin A status and measures of conjunctival epithelial integrity in young children in northern Ghana. European Journal of Clinical Nutrition 1994; Vol. 48, issue 9:669-77. [0954-3007]

Kirkwood BR, Ross DA, Arthur P, Morris SS, Dollimore N, Binka FN, et al. Effect of vitamin A supplementation on the growth of young children in northern Ghana. American Journal of Clinical Nutrition 1996; Vol. 63, issue 5:773-81. [0002-9165]

Kirkwood BR, Ross DA, Arthur P, Morris SS, Dollimore $\mathrm{N}$, Binka FN, et al. Effect of vitamin A supplementation on the growth of young children in northern Ghana. Early Human Development 1996, issue 3:279.

Ross DA, Binka FN, Dollimore N, Smith PG, Addy HA, Tomkins AM, et al. Vitamin A supplementation in northern Ghana: Effects on clinic attendances, hospital admissions, and child mortality. Lancet. Lancet. 342(8862)(pp 7-12), 1993. Date of Publication: 1993., 1993; Vol. 342, issue 8862:7-12. [0140-6736]

Ross DA, Kirkwood BR, Binka FN, Arthur P, Dollimore
$\mathrm{N}$, Morris SS, et al. Child morbidity and mortality following vitamin A supplementation in Ghana: time since dosing, number of doses, and time of year. American Journal of Public Health 1995; Vol. 85, issue 9:1246-51. [0090-0036]

\section{Ross 1993 SURVIVAL \{published data only\}}

Benn CS, Aaby P, Nielsen J, Binka FN, Ross DA. Does vitamin A supplementation interact with routine vaccinations? An analysis of the Ghana Vitamin A Supplementation Trial. American Journal of Clinical Nutrition 2009; Vol. 90, issue 3:629-39.

Binka FN, Ross DA, Morris SS, Kirkwood BR, Arthur P, Dollimore N, et al. Vitamin A supplementation and childhood malaria in northern Ghana. American Journal of Clinical Nutrition 1995; Vol. 61, issue 4:853-9.

[0002-9165]

Dollimore N, Cutts F, Binka FN, Ross DA, Morris SS, Smith PG. Measles incidence, case fatality, and delayed mortality in children with or without vitamin A supplementation in rural Ghana. American Journal of Epidemiology 1997; Vol. 146, issue 8:646-54. [0002-9262]

Filteau SM, Morris SS, Raynes JG, Arthur P, Ross DA, Kirkwood BR, et al. Vitamin A supplementation, morbidity, and serum acute-phase proteins in young Ghanaian children. American Journal of Clinical Nutrition 1995; Vol. 62, issue 2:434-8. [0002-9165]

Filteau SM, Morris SS, Tomkins AM, Arthur P, Kirkwood $\mathrm{BR}$, Ross DA, et al. Lack of association between vitamin A status and measures of conjunctival epithelial integrity in young children in northern Ghana. European Journal of Clinical Nutrition 1994; Vol. 48, issue 9:669-77. [0954-3007]

Kirkwood BR, Ross DA, Arthur P, Morris SS, Dollimore N, Binka FN, et al. Effect of vitamin A supplementation on the growth of young children in northern Ghana. American Journal of Clinical Nutrition 1996; Vol. 63, issue 5:773-81. [0002-9165]

Kirkwood BR, Ross DA, Arthur P, Morris SS, Dollimore $\mathrm{N}$, Binka FN, et al. Effect of vitamin A supplementation on the growth of young children in northern Ghana. Early Human Development 1996, issue 3:279.

* Ross DA, Binka FN, Dollimore N, Smith PG, Addy HA, Tomkins AM, et al. Vitamin A supplementation in northern Ghana: Effects on clinic attendances, hospital admissions, and child mortality. Lancet. Lancet. 342(8862) (pp 7-12), 1993. Date of Publication: 1993., 1993; Vol. 342, issue 8862:7-12. [0140-6736]

Ross DA, Kirkwood BR, Binka FN, Arthur P, Dollimore $\mathrm{N}$, Morris SS, et al. Child morbidity and mortality following vitamin A supplementation in Ghana: time since dosing, number of doses, and time of year. American Journal of Public Health 1995; Vol. 85, issue 9:1246-51. [0090-0036]

Semba 1992 \{published data only\}

* Semba R, Muhilal, Scott A, Natadisastra G, Wirasasmita $S$, Griffin $D$, et al. Immune status in children with mild vitamin A deficiency in Indonesia. Investigative 
Ophthalmology and Visual Science 1991.

Semba RD, Muhilal MPH, West KP Jr. Impact of vitamin A supplementation on hematological indicators of iron metabolism and protein status in children. Nutrition Research 1992; Vol. 12, issue 4:469-78. [0271-5317] Semba RD, Muhilal, Scott AL, Natadisastra G, West KP, Sommer A. Effect of vitamin A supplementation on immunoglobulin $\mathrm{G}$ subclass responses to tetanus toxoid in children. Clinical and Diagnostic Laboratory Immunology 1994 , issue 2:172-5.

Semba RD, Muhilal, Scott AL, Natadisastra G, Wirasasmita $S$, Mele L, et al. Depressed immune response to tetanus in children with vitamin A deficiency. Journal of Nutrition. 1992/01/11 1992; Vol. 122, issue 1:101-7. [0022-3166: (Print)]

\section{Semba 1995 \{published data only\}}

Semba RD, Munasir Z, Beeler J, Akib A, Muhilal, Audet S, et al. Reduced seroconversion to measles in infants given vitamin A with measles vaccination. Lancet. 1995/05/27 1995; Vol. 345, issue 8961:1330-2. [0140-6736: (Print)]

Sempertegui 1999 \{published data only\}

Sempertegui F, Estrella B, Camaniero V, Betancourt V, Izurieta R, Ortiz W, et al. The beneficial effects of weekly low-dose vitamin A supplementation on acute lower respiratory infections and diarrhea in Ecuadorian children. Pediatrics 1999; Vol. 104, issue 1.

Shankar 1999 \{published data only\}

Shankar AH, Genton B, Semba RD, Baisor M, Paino J, Tamja S, et al. Effect of vitamin A supplementation on morbidity due to Plasmodium falciparum in young children in Papua New Guinea: a randomised trial. Lancet 1999, issue 9174:203-9.

Sinha 1976 \{published data only\}

Sinha DP, Bang FB. The effect of massive doses of vitamin A on the signs of vitamin A deficiency in preschool children. American Journal of Clinical Nutrition 1976; Vol. 29, issue 1:110-5. [0002-9165]

\section{Smith 1999 \{published data only\}}

Smith JC, Makdani D, Hegar A, Rao D, Douglass LW. Vitamin A and zinc supplementation of preschool children. Journal of the American College of Nutrition 1999; Vol. 18, issue 3:213-22. [0731-5724]

\section{Sommer 1986 \{published data only\}}

Abdeljaber MH, Monto AS, Tilden RL, Schork MA, Tarwotjo I. The impact of vitamin A supplementation on morbidity: a randomized community intervention trial. American Journal of Public Health 1991; Vol. 81, issue 12: 1654-6. [0090-0036]

Djunaedi E, Sommer A, Pandji A, Kusdiono, Taylor HR. Impact of vitamin A supplementation on xerophthalmia. A randomized controlled community trial. Archives of Ophthalmology 1988; Vol. 106, issue 2:218-22. [0003-9950]

* Sommer A, Tarwotjo I, Djunaedi E, West KP Jr, Loeden AA, et al. Impact of vitamin A supplementation on childhood mortality. A randomised controlled community trial. Lancet 1986; Vol. 8491, issue 31.

Tielsch JM, West KP. Cost and efficiency considerations in community-based trials of vitamin A in developing countries. Statistics in medicine 1990; Vol. 9, issue 1-2:3541; discussion 41-3.

West KP Jr, Djunaedi E, Pandji A. Vitamin A supplementation and growth: a randomized community trial. American Journal of Clinical Nutrition 1988; Vol. 48, issue 5:1257-64. [0002-9165]

Stabell 1995 \{published data only\}

Stabell C, Bale C, Pedro da Silva A, Olsen J, Aaby P. No evidence of fontanelle-bulging episodes after vitamin A supplementation of 6- and 9-month-old infants in Guinea Bissau. European Journal of Clinical Nutrition 1995; Vol. 49, issue 1:73-4. [0954-3007]

\section{Stansfield 1993 \{published data only\}}

Stansfield SK, Muller PL, Lerebours G, Augustin A. Vitamin A supplementation and increased prevalence of childhood diarrhoea and acute respiratory infections. Lancet 1993; Vol. 342, issue 8871:578-82. [0140-6736]

van Agtmaal 1988 \{published data only\} van Agtmaal EJ, Bloem MW, Speek AJ, Saowakontha S, Schreurs HP, van Haeringen NJ. The effect of vitamin A supplementation on tear fluid retinol levels of marginally nourished preschool children. Current Eye Research 1988;7 (1):43-8.

\section{Venkatarao 1996 \{published data only\}}

Venkatarao T, Ramakrishnan R, Nair NG, Radhakrishnan S, Sundaramoorthy L, Koya PK, et al. Effect of vitamin A supplementation to mother and infant on morbidity in infancy. Indian Pediatrics 1996; Vol. 33, issue 4:279-86. [0019-6061]

Vijayaraghavan 1990 \{published data only\} Vijayaraghavan K, Radhaiah G, Surya Prakasam B, Sarma KVR, Reddy V. Effect of massive dose vitamin A on morbidity and mortality in Indian children. Lancet 1990; Vol. 336, issue 8727:1342-5. [0140-6736]

West 1991 \{published data only\} Bishai D, Kumar KCS, Waters H, Koenig M, Katz J, Khatry SK, et al. The impact of vitamin A supplementation on mortality inequalities among children in Nepal. Health Policy and Planning 2005; Vol. 20, issue 1:60-6. [0268-1080] Katz J, West KP Jr, Khatry SK, Thapa MD, LeClerq SC, Pradhan EK, et al. Impact of vitamin A supplementation on prevalence and incidence of xerophthalmia in Nepal. Investigative Ophthalmology and Visual Science 1995; Vol. 36, issue 13:2577-83. [0146-0404]

Pokhrel RP, Khatry SK, West KP, Shrestha SR, Katz J, Pradhan EK, et al. Sustained reduction in child mortality with vitamin A in Nepal. Lancet 1994, issue 8909:1368-9. Shih JH, Lu SE. Analysis of failure time data with multilevel clustering, with application to the child vitamin a 
intervention trial in Nepal. Biometrics 2007; Vol. 63, issue 3:673-80. [0006-341X]

West KP Jr, LeClerq SC, Shrestha SR, Wu LSF, Pradhan EK, Khatry SK, et al. Effects of vitamin A on growth of vitamin A-deficient children: Field studies in Nepal. Journal of Nutrition 1997; Vol. 127, issue 10:1957-65. [0022-3166] * West KP Jr, Pokhrel RP, Katz J, LeClerq SC, Khatry SK, Shrestha SR, et al. Efficacy of vitamin A in reducing preschool child mortality in Nepal. Lancet 1991; Vol. 338, issue 8759:67-71. [0140-6736]

\section{References to studies excluded from this review}

Bahl 1997 \{published data only\}

Bahl R, Bhandari N, Taneja S, Bhan MK. The impact of vitamin A supplementation on physical growth of children is dependent on season. European Journal of Clinical Nutrition. 1997/01/01 1997; Vol. 51, issue 1:26-9. [0954-3007: (Print)]

Bhaskaram 1997 \{published data only\} Bhaskaram P, Rao KV. Enhancement in seroconversion to measles vaccine with simultaneous administration of vitamin A in 9-months-old Indian infants. Indian Journal of Pediatrics. 1997/07/01 1997; Vol. 64, issue 4:503-9. [0019-5456: (Print)]

Bloem 1990 \{published data only\} Bloem MW, Wedel M, Agtmaal EJ, Speek AJ, Saowakontha $S$, Schreurs WHP. Vitamin A intervention: short-term effects of a single, oral, massive dose on iron metabolism. American Journal of Clinical Nutrition 1990; Vol. 51, issue 1:76-9. [0002-9165]

\section{Kothari 1991 \{published data only\}}

Kothari G. The Effect of Vitamin A Prophylaxis on Morbidity and Mortality Among Children in Urban Slums in Bombay. Journal of Tropical Pediatrics 1991; Vol. 37: 141.

Semba 1990 \{published data only\}

Semba RD, Wirasasmita S, Natadisastra G, Muhilal, Sommer A. Response of Bitot's spots in preschool children to vitamin A treatment. American Journal of Ophthalmology. 1990/10/15 1990; Vol. 110, issue 4:416-20. [0002-9394: (Print)]

Semba 2005 \{published data only\}

Semba RD, Ndugwa C, Perry RT, Clark TD, Jackson JB, Melikian G, et al. Effect of periodic vitamin A supplementation on mortality and morbidity of human immunodeficiency virus-infected children in Uganda: A controlled clinical trial. Nutrition. 2005/01/22 2005; Vol. 21, issue 1:25-31. [0899-9007: (Print)]

Wu 2007 \{published data only\}

Z. Wu, L. Lin, Ouyang L. Impact of vitamin A on the immune function of infants. China Tropical Medicine 2007; 7(4):540-1.

Yang 2002 \{published data only\}

Yang YX, Han JH, Shao XP, He M, Bian LH, Wang Z, et al. Effect of micronutrient supplementation on the growth of preschool children in China. Biomedical and
Environmental Sciences. 2002/12/26 2002; Vol. 15, issue 3:196-202. [0895-3988: (Print)]

\section{References to studies awaiting assessment}

Aklamati 2006 \{published data only\}

Aklamati E, Brown KH, Mulenga M, Kafwembe E, Peerson JM, Stephensen C, et al. Impact of high-dose vitamin A supplements on vitamin A status of 3-4 year old Zambian boys. FASEB Journal 2006; Vol. 20, issue 5, Part 2.

DEVTA trial 2007 \{published data only\}

Awasthi S, Peto R, Bundy D, Read S, Kourellias K, Clark S, et al. Six-monthly vitamin A supplementation from 1 to 6 years of age. Abstract of talk at ILSI Micronutrient Forum, Istanbul, 16-18 April 2007. http://www.ctsu.ox.ac.uk/ projects/devta/index' html.

\section{Additional references}

\section{Alvarez 1995}

Alvarez JO, Salazar-Lindo E, Kohatsu J, Miranda P, Stephensen CB. Urinary excretion of retinol in children with acute diarrhoea. American Journal of Clinical Nutrition 1995;61(6):1273-6.

\section{Bates 1995}

Bates CJ. Vitamin A. Lancet 1995;345(8941):31-5.

Beaton 1993

Beaton GH, Martorell R, Aronson KJ, Edmonston B, McCabe G, Ross AC, et al. Effectiveness of Vitamin A supplementation in the control of young child morbidity and mortality in developing countries. ACC/SCN State of the Art Series, Nutrition 1993;Policy Discussion Paper:No. 13.

Bello 2009

Bello S, Meremikwu MM, Ejemot RI. Routine vitamin A supplementation for the prevention of blindness due to measles infection in children. Cochrane Database of Systematic Reviews 2009, Issue 2. [DOI: 10.1002/ 14651858.CD007719]

Benn 2003

Benn CS, Bale C, Sommerfelt H, Friis H, Aaby P. Hypothesis: Vitamin A supplementation and childhood mortality: amplification of the non-specific effects of vaccines?. International Journal of Epidemiology. 2003/10/ 16 2003; Vol. 32, issue 5:822-8. [0300-5771: (Print)]

\section{Chen 2008}

Chen H, Zhuo Q, Yuan W, Wang J, Wu T. Vitamin A for preventing acute lower respiratory tract infections in children up to seven years of age. Cochrane Database of Systematic Reviews 2008, Issue 1. [DOI: 10.1002/ 14651858.CD006090.pub2]

Darlow 2007

Darlow BA, Graham PJ. Vitamin A supplementation to prevent mortality and short and long-term morbidity in very low birthweight infants. Cochrane Database of Systematic Reviews 2007, Issue 4. [DOI: 10.1002/ 14651858.CD000501.pub2] 
Fawzi 1993

Fawzi WW, Chalmers TC, Herrera MG, Mosteller F. Vitamin A supplementation and child mortality. JAMA 1993;269(7):898-903.

Fawzi 2006

Fawzi WW. The benefits and concerns related to vitamin A supplementation. Journal of Infectious Diseases 2006;193(6): 756-9.

Glasziou 1993

Glasziou PP, Mackerras DEM. Vitamin A supplementation in infectious diseases: A meta-analysis. BMJ 1993;306 (6874):366-70.

Gogia 2008

Gogia S, Sachdev HS. Vitamin A supplementation for the prevention of morbidity and mortality in infants six months of age or less. Cochrane Database of Systematic Reviews 2008, Issue 4. [DOI: 10.1002/14651858.CD007480]

Gogia 2008a

Gogia S, Sachdev HPS. Web Appendix 10. Review of vitamin $A$ supplementation in pregnancy and childhood. In: Bhutta ZA, Ahmed T, Black RE, Cousens S, Dewey K, Giugliani E, et al. What works? Interventions for maternal and child undernutrition and survival. Lancet 2008;371 (9610):417-40

\section{Green 1928}

Green H, Mellanby E. Vitamin A as an anti-infective agent. British Medical Journal 1928;2:691-6.

\section{Haider 2008}

Haider BA, Irfan FB, Bhutta ZA. Neonatal vitamin A supplementation for the prevention of mortality and morbidity in term neonates in developing countries. Cochrane Database of Systematic Reviews 2008, Issue 1. [DOI: 10.1002/14651858.CD006980]

\section{Haskell 1999}

Haskell MJ, Brown KH. Maternal vitamin A nutriture and the vitamin A content of human milk. Journal of Mammary Gland Biology and Neoplasia 1999;4(3):243-57.

Hathcock 1997

Hathcock JN. Vitamins and minerals: efficacy and safety. American Journal of Clinical Nutrition 1997;66(2):427-37.

Higgins 2008

Higgins JPT, Green S (editors). Cochrane Handbook for Systematic Reviews of Interventions Version 5.0.1 [updated September 2008]. The Cochrane Collaboration, 2008. Available from www.cochrane-handbook.org.

Imdad 2010

Imdad A, Yakoob MY, Haider BA, Bhutta ZA. Preventive and Therapeutic Effects of Vitamin A Supplementation on Infant and Childhood Morbidity and Mortality: A Systematic Review. In: Bhutta ZA editor(s). Nutrition Interventions for Maternal and Child Health and Survival. Vol. 1, Oxford University Press, 2010:125-39.

Kirkwood 2010

Kirkwood B, Humphrey J, Moulton L, Martines J. Neonatal vitamin A supplementation and infant survival. Lancet 2010;6737(10):61895-8.

\section{Klemm 2009}

Klemm RD, West KJ, Tielsh J, Wu L, Katz J. Pooled analysis of Asian newborn vitamin A supplementation trials to assess differential effects of early infant mortality. Micronutrients, health and development: Evidence-based programs. Beijing, China, 2009.

\section{Klemm 2010}

Klemm RD, West KP Jr, Palmer AC, Johnson Q, Randall P, Ranum P, et al. Vitamin A fortification of wheat flour: considerations and current recommendations. Food and Nutrition Bulletin 2010;31(1 Suppl):S47-61.

\section{Latham 2010}

Latham M. The great vitamin A fiasco. World Nutrition May 2010;1(1):12-45.

\section{Mayo-Wilson 2007}

Mayo-Wilson E. Reporting implementation in randomized trials: proposed additions to the consolidated standards of reporting trials statement. American Journal of Public Health. 2007/03/03 2007; Vol. 97, issue 4:630-3. [1541-0048: (Electronic)]

Mitra 1998

Mitra AK, Alvarez JO, Guay-Woodford L, Fuchs GJ, Wahed MA, Stephenson CB. Urinary retinol excretion and kidney function in children with shigellosis. American Journal of Clinical Nutrition 1998;68(5):1095-103.

\section{Ni 2005}

Ni J, Wei J, Wu T. Vitamin A for non-measles pneumonia in children. Cochrane Database of Systematic Reviews 2005, Issue 3. [DOI: 10.1002/14651858.CD003700.pub2]

\section{Oliveira 2006}

Oliveira JM, Bergamaschi DP, East CE, Pai M. Vitamin A supplementation for breastfeeding mothers. Cochrane Database of Systematic Reviews 2006, Issue 2. [DOI: 10.1002/14651858.CD005944]

\section{Ramakrishnan 2002}

Ramakrishnan U, Darnton-Hill I. Assessment and control of vitamin A deficiency disorders. Journal of Nutrition 2002 132(9 Suppl):2947-53.

\section{RevMan 2008 [Computer program]}

The Nordic Cochrane Centre, The Cochrane Collaboration. Review Manager (RevMan). Version 5.0. Copenhagen: The Nordic Cochrane Centre, The Cochrane Collaboration, 2008.

Rice 2004

Rice AL, West KP Jr, Black RE. Vitamin A deficiency. In: Global and regional burden of disease attributable to selected major risk factors. Vol. 1, Geneva: World Health Organization, 2004.

\section{Rotondi 2010}

Rotondi MA, Khobzi N. Vitamin A supplementation and neonatal mortality in the developing world: a metaregression of cluster-randomized trials. Bulletin of the World Health Organization 2010;88(9):697-702. 


\section{Semba 1999}

Semba, RD. Vitamin A and immunity to viral, bacterial and protozoan infections. Proceedings of the Nutrition Society 1999;58(3):719-27.

Shenai 1993

Shenai JP. Vitamin A. In: Tsang RC, Lucas A, Uauy R editor(s). Nutritional needs of the preterm infant: scientific basis and practical guidelines. Baltimore: Williams and Williams, 1993:87-100.

\section{Smith 1976}

Smith FR, Goodman DS. Vitamin A transport in human vitamin A toxicity. New England Journal of Medicine 1976; 294(15):805-8.

Sommer 1996

Sommer A, West KP Jr. Vitamin A deficiency: Health, Survival and Vision. New York: Oxford University Press, 1996.

Sommer 2002

Sommer A, Davidson FR. Assessment and Control of Vitamin A Deficiency: The Annecy Accords. Journal of Nutrition 2002;132(9):2845-50.

US Institute of Medicine, Food and Nutrition Board US Institute of Medicine, Food, Nutrition Board. Standing Committee on the Scientific Evaluation of Dietary Reference Intakes. Dietary reference intakes for vitamin A, vitamin $K$, arsenic, boron, chromium, copper, iodine, iron, manganese, molybdenum, nickel, silicon, vanadium, and zinc. Washington DC: National Academy Press, 2000.

van den Broek 2002

van den Broek N, Kulier R, Gülmezoglu AM, Villar J. Vitamin A supplementation during pregnancy. Cochrane Database of Systematic Reviews 2002, Issue 4. [DOI: 10.1002/14651858.CD001996]

\section{Villamor 2000}

Villamor E, Fawzi WW. Vitamin A supplementation: implications for morbidity and mortality in children.
Journal of Infectious Diseases. 2000/08/17 2000; Vol. 182 Suppl 1:S122-33. [0022-1899: (Print)]

\section{West 2002}

West CE, Eilander A, van Lieshout M. Consequences of revised estimates of carotenoid bioefficacy for dietary control of vitamin A deficiency in developing countries. Journal of Nutrition 2002;132(9 Suppl):2920-6.

\section{West 2002a}

West KP Jr. Extent of vitamin A deficiency among preschool children and women of reproductive age. Journal of Nutrition 2002;132(9):2857-66.

\section{West KP 2003}

West KP Jr. Vitamin A deficiency disorders in children and women. Food and Nutrition Bulletin 2003;4(suppl 4): S78-S90.

\section{WHO 1997}

WHO. Vitamin A supplements; A guide to their use in prevention and treatment of vitamin $A$ deficiency and xerophthalmia. Geneva: World Health Organization, 1997.

\section{WHO 2009}

WHO. Global prevalence of vitamin A deficiency in populations at risk 1995-2005. WHO Global Database on Vitamin A Deficiency 2009.

\section{Wiysonge 2005}

Wiysonge CSU, Shey M, Kongnyuy EJ, Sterne JAC, Brocklehurst P. Vitamin A supplementation for reducing the risk of mother-to-child transmission of HIV infection. Cochrane Database of Systematic Reviews 2005, Issue 4. [DOI: 10.1002/14651858.CD003648.pub2]

\section{Yang 2009}

Yang HM, Mao M, Wan CM. Vitamin A for treating measles in children. Cochrane Database of Systematic Reviews 2005, Issue 4. [DOI: 10.1002/14651858.CD001479.pub3]

* Indicates the major publication for the study 


\title{
CHARACTERISTICS OF STUDIES
}

\section{Characteristics of included studies [ordered by study ID]}

\author{
Agarwal 1995
}

\begin{tabular}{ll}
\hline Methods & Cluster randomised trial conducted in Uttar Pradesh, India, Asia \\
\hline Participants & $\begin{array}{l}\text { All children below } 6 \text { years of age were eligible for inclusion in the trial. Children with } \\
\text { xerophthalmia were excluded } \\
\text { A total of } 16 \text { clusters (subcentres) were randomly selected. Four subdivisions (4 subcentres } \\
\text { in each) were made and drugs A (vitamin A) and B (placebo) distributed in two each } \\
\text { randomly. It was found at the end of the study that by mistake vitamin 'A' was distributed } \\
\text { in } 3 \text { subdivisions (12 subcentres) and placebo in } 1 \text { only ( } 4 \text { subcentres). A total of } 17,778 \\
\text { children were approached but only 15,247 children were included in the final analysis } \\
\text { based on the fact that they received at least } 1 \text { dose of vitamin A }\end{array}$ \\
\hline
\end{tabular}

Interventions

Children in experimental group received vitamin A along with small amounts of vitamin E. The dosages were 50,000 IU of vitamin A and 10 IU of vitamin E for children 1-6 months and 100,000 IU of vitamin A and 20 IU of vitamin E for children 7-72 months. The intervention was delivered every 4 months and continued for 12 months

Outcomes All-cause and cause specific mortality of diarrhoea, pneumonia, measles and meningitis

Notes

The trial was conducted in two phases. First phase consisted of 15 months i.e. 3 months for registration and 12 months for intervention and measurement of relevant outcomes. In second phase, mortality was measured in a sub-sample of initially included children exactly after 12 months of termination of first phase. The cause of death was assigned by using a verbal autopsy tool. Baseline mortality rates for children below 6 years of age were 27 . 7 and 23.3 per 1000 for intervention and control group respectively and was significantly different in two groups $(\mathrm{P}<0.01)$. According to $\mathrm{WHO}$, India is a country with a high child mortality rate (i.e. $>40 / 1000)$

Risk of bias

\begin{tabular}{|c|c|c|}
\hline Bias & Authors' judgement & Support for judgement \\
\hline Adequate sequence generation? & Unclear risk & $\begin{array}{l}\text { "Out of the total } 43 \text { subcentres, } 16 \text { were ran- } \\
\text { domly selected, four subdivisions ( } 4 \text { subcen- } \\
\text { tres in each) were made and drugs A and B } \\
\text { distributed in two each randomly" } \\
\text { Authors do not specify the method of se- } \\
\text { quence generation. }\end{array}$ \\
\hline Allocation concealment? & Unclear risk & $\begin{array}{l}\text { Insufficent information to permit judg- } \\
\text { ment. }\end{array}$ \\
\hline $\begin{array}{l}\text { Blinding? } \\
\text { Blinding of Participants }\end{array}$ & Unclear risk & $\begin{array}{l}\text { Insufficent information to permit judg- } \\
\text { ment. }\end{array}$ \\
\hline
\end{tabular}

Vitamin A supplementation for preventing morbidity and mortality in children from 6 months to 5 years of age (Review) 
Agarwal 1995 (Continued)

\begin{tabular}{|c|c|c|}
\hline $\begin{array}{l}\text { Blinding? } \\
\text { Blinding of provider }\end{array}$ & Unclear risk & $\begin{array}{l}\text { Insufficent information to permit judg- } \\
\text { ment. }\end{array}$ \\
\hline $\begin{array}{l}\text { Blinding? } \\
\text { Blinding of outcome assessor }\end{array}$ & Unclear risk & $\begin{array}{l}\text { Insufficent information to permit judg- } \\
\text { ment. }\end{array}$ \\
\hline Incomplete outcome data addressed? & Unclear risk & $\begin{array}{l}\text { Insufficent information to permit judg- } \\
\text { ment. }\end{array}$ \\
\hline Free of selective reporting? & Unclear risk & $\begin{array}{l}\text { Insufficent information to permit judg- } \\
\text { ment. }\end{array}$ \\
\hline Free of other bias? & Unclear risk & $\begin{array}{l}\text { Insufficent information to permit judg- } \\
\text { ment. }\end{array}$ \\
\hline
\end{tabular}

\section{Arya 2000}

\begin{tabular}{ll} 
Methods & Individually randomised trial conducted in New Delhi, India, Asia \\
\hline Participants & $\begin{array}{l}\text { Infants age 9-12 months attending immunisation clinic of Safdurjung hospital in New } \\
\text { Delhi were eligible for inclusion in the trial. Sick infants requiring hospitalisation were } \\
\text { excluded } \\
\text { A total of } 256 \text { infants were enrolled in the study with equal numbers (i.e. 128) in vitamin } \\
\text { A and placebo group. Mean age of participants was } 9 \text { months }\end{array}$ \\
\hline Interventions & $\begin{array}{l}\text { The experimental group received a single dose of } 100 \text { 000 IU of vitamin A in Archis } \\
\text { oil. The control group received placebo in peanut oil. Both vitamin A and placebo were } \\
\text { administered at the time of measles vaccination. At the end of study vitamin A group } \\
\text { received placebo and placebo group received vitamin A }\end{array}$ \\
\hline Outcomes & $\begin{array}{l}\text { Incidence of side effects in first } 24 \text { hours: vomiting, loose motions, fever, irritability, bulging } \\
\text { fontanelle }\end{array}$ \\
\hline Notes & $\begin{array}{l}\text { Study participants were not significantly different in sex, age and weight distribution and } \\
\text { nutritional status at the baseline. The baseline prevalence of vomiting, loose stools, fever } \\
\text { and irritability during } 24 \text { hours prior to dosing was similar in both groups. } 97.3 \% \text { of the } \\
\text { included infants had normal serum retinol level before the study }\end{array}$
\end{tabular}

\section{Risk of bias}

\begin{tabular}{|c|c|c|}
\hline Bias & Authors' judgement & Support for judgement \\
\hline Adequate sequence generation? & High risk & $\begin{array}{l}\text { "The infants were randomised ... accord- } \\
\text { ing to the order of arrival at hospital. Ran- } \\
\text { domisation was done by the nurse who gave } \\
\text { measles vaccine to these children." } \\
\text { Probably not done. }\end{array}$ \\
\hline
\end{tabular}


Arya 2000 (Continued)

\begin{tabular}{|c|c|c|}
\hline Allocation concealment? & Unclear risk & $\begin{array}{l}\text { Children were randomised according to } \\
\text { their entry into hospital }\end{array}$ \\
\hline $\begin{array}{l}\text { Blinding? } \\
\text { Blinding of Participants }\end{array}$ & Low risk & $\begin{array}{l}\text { "This double-blind, randomised, ... sup- } \\
\text { plied in small dark bottles marked '1' and } \\
\text { '2'." }\end{array}$ \\
\hline $\begin{array}{l}\text { Blinding? } \\
\text { Blinding of provider }\end{array}$ & Low risk & $\begin{array}{l}\text { "This double-blind, randomised, ... sup- } \\
\text { plied in small dark bottles marked ' } 1 \text { ' and } \\
\text { '2'." }\end{array}$ \\
\hline $\begin{array}{l}\text { Blinding? } \\
\text { Blinding of outcome assessor }\end{array}$ & Low risk & $\begin{array}{l}\text { "This double-blind, randomised, ... sup- } \\
\text { plied in small dark bottles marked '1' and } \\
\text { '2' ... Two clinicians examined each of the } \\
\text { infants at both first and second visits. Nei- } \\
\text { ther clinician knew the bottle code." }\end{array}$ \\
\hline Incomplete outcome data addressed? & High risk & $\begin{array}{l}\text { A total of } 39(15.2 \%) \text { infants were lost to } \\
\text { follow-up with similar distribution in both } \\
\text { the groups. Reasons for loss to follow-up not } \\
\text { given }\end{array}$ \\
\hline Free of selective reporting? & High risk & $\begin{array}{l}\text { Methods describe that the clinicians did } \\
\text { physical examinations and recorded weight, } \\
\text { nutritional status, any signs of vitamin A } \\
\text { deficiency, heart rate, respiratory rate, tem- } \\
\text { perature and systemic examination espe- } \\
\text { cially neurological examination including } \\
\text { the state of the fontanelle, reflexes, mo- } \\
\text { tor and sensory functions, etc. But bulging } \\
\text { fontanelle not reported as an outcome, nei- } \\
\text { ther other variables mentioned in the results }\end{array}$ \\
\hline Free of other bias? & Low risk & $\begin{array}{l}\text { No other apparent bias was noted in the } \\
\text { study. }\end{array}$ \\
\hline
\end{tabular}

\section{Bahl 1999}

Methods

Participants
This individually randomised study was conducted in an urban slum of Delhi, India, Asia

Infants aged 6-9 months were identified and enrolled into study when they became 9 months old. Those infants were excluded who had a previous history of measles, contact with a case of measles or measles immunisation, or if they had received a dose of vitamin $\mathrm{A}$ in the previous 4 months. Participants with serious illness requiring hospitalisation or having clinical signs of vitamin A deficiency (i.e. xerophthalmia, Bitot's spots etc.) were also excluded

A total of 618 infants were enrolled and randomised either to vitamin A (309) or placebo group (309). $50 \%$ of study population consisted of male infants 
Bahl 1999 (Continued)

\begin{tabular}{l|l} 
Interventions & $\begin{array}{l}\text { Participants in intervention group were given a single dose of } 30 \mathrm{mg} \text { (100 000 IU) of } \\
\text { vitamin A in the form of retinol palmitate and control group received soybean oil as } \\
\text { placebo. Children were followed for four months }\end{array}$ \\
\hline Outcomes & $\begin{array}{l}\text { Antibody response to measles vaccine. Incidence of measles during study period and side } \\
\text { effects like vomiting, drowsiness etc in first } 48 \text { hours were also reported }\end{array}$ \\
\hline Notes & $\begin{array}{l}\text { The primary objective of the study was to determine the response to measles vaccine when } \\
\text { administered along with vitamin A at } 9 \text { months of age. The study found no significant } \\
\text { difference in antibody titers between the two groups at three months after the administra- } \\
\text { tion of intervention. The baseline prevalence of clinical vitamin A deficiency in children } \\
1-5 \text { years in study area was } 3.5 \% \text { and that of biochemical vitamin A deficiency of } 37 \%\end{array}$ \\
\hline
\end{tabular}

\section{Risk of bias}

Bias Authors' judgement $\quad$ Support for judgement

Adequate sequence generation? Low risk

"Infants were randomly assigned to receive vitamin A or a placebo by using a simple randomisation scheme with random permuted blocks of size eight, i.e., four infants each out of every eight infants enrolled were randomised to receive vitamin A or a placebo." Probably done.

\begin{tabular}{|c|c|c|}
\hline Allocation concealment? & Unclear risk & $\begin{array}{l}\text { Insufficent information to permit judg- } \\
\text { ment. }\end{array}$ \\
\hline $\begin{array}{l}\text { Blinding? } \\
\text { Blinding of Participants }\end{array}$ & Low risk & $\begin{array}{l}\text { "This scheme ensured that all infants re- } \\
\text { ceived } 30 \mathrm{mg} \text { vitamin A by } 12 \text { mo of age } \\
\text { without interfering with the double-blind } \\
\text { design of the study." } \\
\text { Probably done. }\end{array}$ \\
\hline $\begin{array}{l}\text { Blinding? } \\
\text { Blinding of provider }\end{array}$ & Low risk & $\begin{array}{l}\text { Adequate masking of vitamin A and placebo } \\
\text { should have meant that providers were ade- } \\
\text { quately blinded }\end{array}$ \\
\hline $\begin{array}{l}\text { Blinding? } \\
\text { Blinding of outcome assessor }\end{array}$ & Low risk & $\begin{array}{l}\text { Adequate masking of vitamin } \mathrm{A} \text { and placebo } \\
\text { should have meant that outcome assessors } \\
\text { were adequately blinded }\end{array}$ \\
\hline Incomplete outcome data addressed? & High risk & $\begin{array}{l}\text { Losses to follow-up and exclusions de- } \\
\text { scribed. Missing data excluded from the } \\
\text { analysis. It is not possible to ascertain } \\
\text { whether the exclusion of data from } 17 \% \\
\text { of participants (equally distributed between } \\
\text { treatment groups) would have impacted on }\end{array}$ \\
\hline
\end{tabular}

Vitamin A supplementation for preventing morbidity and mortality in children from 6 months to 5 years of age (Review) 
Bahl 1999 (Continued)

the results. The investigators state that the reason for their exclusion is that a follow-up serum sample could not be ascertained

Free of selective reporting?

High risk

Data on harms are incompletely disclosed in the study report

Free of other bias?

Low risk

This study appears to be free of other bias.

Barreto 1994

\begin{tabular}{ll} 
Methods & Individually randomised trial conducted in Serrinha, Brazil, Latin America \\
\hline Participants & $\begin{array}{l}\text { Children aged } 6 \text { to } 48 \text { months were eligible for inclusion in the trial. Exclusion criteria } \\
\text { was presence of xerophthalmia or measles infection within the previous } 30 \text { days. Children } \\
\text { who received a high dose of vitamin A supplementation in the previous } 6 \text { months or had } \\
\text { weight-for-age less than } 60 \% \text { of the statistical median were also excluded } \\
\text { A total of } 1240 \text { children were included, } 620 \text { in vitamin A group and } 620 \text { in placebo. Mean } \\
\text { age of participants was } 28 \text { months and the proportion of males was } 52 \%\end{array}$
\end{tabular}

Interventions

The experimental group received vitamin A in a dose of 100,000 IU for children younger than 12 months and 200,000 IU for the older. The control group received placebo only. The intervention was delivered every 4 months for 1 year

Outcomes

All-cause mortality, incidence and prevalence of diarrhoea and respiratory tract disease. Incidence of measles and xerophthalmia

Notes

The study area had inadequate pubic health services. A previous survey in the area showed biochemical deficiency (serum vitamin A concentration $<0.35 \mathrm{mmol} / \mathrm{L}$ ) rate of $7.4 \%$ in children of this age group. According to WHO criteria, vitamin A deficiency should be considered a pubic health problem in this area. The surveillance for morbidity outcome was done 3 times per week for 1 year, so the recall period was 48 to 72 hours. We took data for incidence of measles and xerophthalmia from account of attrition in results section. According to WHO, Brazil does not have a high child mortality rate (i.e. < 40/1000)

\section{Risk of bias}

\section{Bias}

Adequate sequence generation?

Allocation concealment?
Authors' judgement

Unclear risk

\section{Support for judgement}

"Children were randomly assigned to receive vitamin A or placebo four times-at the start of the trial and every 4 months thereafter." Authors do not specify the method of sequence generation.

“...only an external investigator had the codes for the individually wrapped and numbered capsules." 


\begin{tabular}{|c|c|c|}
\hline & & $\begin{array}{l}\text { Although specific details were not disclosed, } \\
\text { the available information suggests that allo- } \\
\text { cation was adequately concealed }\end{array}$ \\
\hline $\begin{array}{l}\text { Blinding? } \\
\text { Blinding of Participants }\end{array}$ & Low risk & $\begin{array}{l}\text { "The gelatinous capsules of vitamin A and } \\
\text { placebo (supplied by Hoffman La Roche) } \\
\text { were identical in appearance and were un- } \\
\text { wrapped just before administration." } \\
\text { The study was double-blind, with identical } \\
\text { presentation and dosing of vitamin A and } \\
\text { placebo }\end{array}$ \\
\hline $\begin{array}{l}\text { Blinding? } \\
\text { Blinding of provider }\end{array}$ & Low risk & $\begin{array}{l}\text { "The gelatinous capsules of vitamin A and } \\
\text { placebo (supplied by Hoffman La Roche) } \\
\text { were identical in appearance and were un- } \\
\text { wrapped just before administration." } \\
\text { Probably done. }\end{array}$ \\
\hline $\begin{array}{l}\text { Blinding? } \\
\text { Blinding of outcome assessor }\end{array}$ & Low risk & $\begin{array}{l}\text { "The study was kept double-blind and only } \\
\text { an external investigator had the codes for the } \\
\text { individually wrapped and numbered cap- } \\
\text { sules." } \\
\text { If the assessors were not involved in the allo- } \\
\text { cation process as suggested by the available } \\
\text { information, outcome assessors were likely } \\
\text { to have been blinded to treatment group as- } \\
\text { signment }\end{array}$ \\
\hline Incomplete outcome data addressed? & Low risk & $\begin{array}{l}\text { "The total loss in follow-up time was } 10 \text {. } \\
3 \% \text {, equally distributed between the study } \\
\text { groups." } \\
\text { The rate of attrition was balanced between } \\
\text { the two treatment groups, and was primar- } \\
\text { ily attributable to migration. On that basis, } \\
\text { attrition bias is not likely to have impacted } \\
\text { on the results of the review }\end{array}$ \\
\hline Free of selective reporting? & Unclear risk & $\begin{array}{l}\text { The protocol for the study was not available } \\
\text { and as such, this aspect of the reporting of } \\
\text { the study could not be assessed }\end{array}$ \\
\hline Free of other bias? & Low risk & $\begin{array}{l}\text { This study appears to be free of other po- } \\
\text { tential bias. }\end{array}$ \\
\hline
\end{tabular}


Methods
Individualy randomised trial conducted in Belem and Mindra, two districts in Bissau, the capital of Guinea-Bissau, Africa
Participants

Infants aged 6-9 months were eligible for inclusion in the trial. Those with signs of xerophthalmia, history of previous vitamin A supplementation, history of measles infection before age 9 months or who had a positive haemagglutinin-inhibition assay (HIA) titre at age 9 months, were excluded. All infants reported to have had measles between 9 to 18 months of age were also excluded

A total of 462 infants were randomised to either intervention or control group. The mean age of participants was 8.7 months and proportion of males was $51 \%$

Interventions

There were three study groups:

Group 1: included "infants aged 6 months and were randomly allocated to receive either a dose of measles vaccine at 6 months and a dose of measles vaccine at 9 months together with vitamin A supplement or the same dosing of measles vaccine with placebo as the supplement"

Group 2: consisted of "infants who were randomly allocated either poliomyelitis vaccine at 6 months and a single dose of measles vaccine at 9 months with vitamin A supplement or the same vaccine doings with a placebo as the supplement"

Group 3: included "Infants who were older than 7.5 months at the beginning of the study or who were not found at home until they reached the age of 7.5 months. They were included in the study at age 9 months and received a measles vaccine plus vitamin A or placebo supplement at that age

Vitamin A was supplemented in a single dose of 100000 IU dissolved in $1 \mathrm{ml}$ of vegetable oil along with $40 \mathrm{IU}$ of vitamin E. The placebo group received $40 \mathrm{IU}$ of vitamin E dissolved in vegetable oil

Antibody response to measles vaccine, all-cause mortality, incidence of measles

Notes

The primary objective of the study was to calculate the antibody response to measles vaccine when given with vitamin A. The results for antibody response to measles vaccine showed no significant difference between the groups. It was concluded from the study that simultaneous administration of measles vaccine and vitamin A has no negative effect on measles immunity. Similarly vitamin A supplementation was shown to have no significant effect on immune response of CD4 and CD8 T-cell in children without clinical vitamin A deficiency. Please note that vitamin A or placebo was given only at 9 months of age in all three study groups. The only difference among the groups was the frequency and type of vaccine administered. We therefore added all the numbers for all three intervention and placebo groups to report the outcomes of interest to our review. We primarily took data from trial flow diagram and calculated the effect sizes accordingly

\section{Risk of bias}

\begin{tabular}{lll} 
Bias & Authors' judgement & Support for judgement \\
\hline Adequate sequence generation? & Low risk & $\begin{array}{l}\text { "The allocation sequence was computer } \\
\text { generated.” }\end{array}$
\end{tabular}

Vitamin A supplementation for preventing morbidity and mortality in children from 6 months to 5 years of age (Review) 
Benn 1997 (Continued)

\begin{tabular}{|c|c|c|}
\hline Allocation concealment? & Low risk & $\begin{array}{l}\text { "The allocation sequence was kept in sealed } \\
\text { envelopes and only released when all clinical } \\
\text { laboratory analyses were completed." }\end{array}$ \\
\hline $\begin{array}{l}\text { Blinding? } \\
\text { Blinding of Participants }\end{array}$ & Low risk & $\begin{array}{l}\text { Identical presentation: "...because of the } \\
\text { young age of the participants, any difference } \\
\text { in taste was irrelevant..." } \\
\text { Probably adequate. }\end{array}$ \\
\hline $\begin{array}{l}\text { Blinding? } \\
\text { Blinding of provider }\end{array}$ & Low risk & $\begin{array}{l}\text { "None of the staff involved knew whether } \\
\text { the bottles contained vitamin A or placebo. } \\
. . "\end{array}$ \\
\hline $\begin{array}{l}\text { Blinding? } \\
\text { Blinding of outcome assessor }\end{array}$ & Low risk & $\begin{array}{l}\text { "None of the staff involved knew whether } \\
\text { the bottles contained vitamin A or placebo. } \\
. . " \\
\text { Masking of treatment group assignment and } \\
\text { treatment to study personnel likely to have } \\
\text { been maintained throughout }\end{array}$ \\
\hline Incomplete outcome data addressed? & Low risk & $\begin{array}{l}\text { Number lost to follow-up and those ex- } \\
\text { cluded were explicitly described and was } \\
\text { equal in both the groups. Loss to follow-up } \\
\text { exceeded the number of deaths and children } \\
\text { with measles. Reasons for missing data (mi- } \\
\text { gration) probably unrelated to treatment }\end{array}$ \\
\hline Free of selective reporting? & Low risk & $\begin{array}{l}\text { Some evidence of selective outcome report- } \\
\text { ing around malaria; however, deaths and } \\
\text { prevalence of measles reported }\end{array}$ \\
\hline Free of other bias? & Unclear risk & $\begin{array}{l}\text { Authors report imbalance in self-reported } \\
\text { disease in the children aged } 6 \text { months at } \\
\text { baseline. It is unclear how big an impact this } \\
\text { will have had as the variable is not specific }\end{array}$ \\
\hline
\end{tabular}

Biswas 1994

Methods

This study was an individual randomised, placebo-controlled trial conducted in GobindaKhatick slum area of eastern Calcutta, India, Asia

Participants

Children aged 12-71 months were eligible for inclusion in the study. Participants with signs of vitamin A deficiency (for example, xeropthalmia) were excluded A total of 180 children were randomised either to vitamin A or placebo group. Mean age of children and proportion of males were not specified in the study 
Biswas 1994 (Continued)

\begin{tabular}{ll}
\hline Interventions & $\begin{array}{l}\text { The experimental group received } 200000 \text { IU of vitamin A in the form of retinyl palmitate. } \\
\text { The control group received placebo. Only a single dose of intervention was administered } \\
\text { and children were followed for } 6 \text { months }\end{array}$ \\
\hline Outcomes & Incidence of diarrhoea and acute respiratory tract infection \\
\hline Notes & $\begin{array}{l}\text { The baseline age and nutritional characteristics were similar in both the groups. The } \\
\text { surveillance for morbidity outcomes was done fortnightly. For respiratory disease morbid- } \\
\text { ity, we took data for lower respiratory tract infection only }\end{array}$ \\
\hline
\end{tabular}

Risk of bias

\begin{tabular}{|c|c|c|}
\hline Bias & Authors' judgement & Support for judgement \\
\hline Adequate sequence generation? & Low risk & $\begin{array}{l}\text { Block randomisation by age and weight: } \\
\text { "For each strata, a restricted randomisation } \\
\text { list was prepared (...) a random permutated } \\
\text { block of block length } 6 \text { was used." } \\
\text { Probably done. }\end{array}$ \\
\hline Allocation concealment? & Low risk & $\begin{array}{l}\text { "...randomisation was done by a pharmacist } \\
\text { of the drug manufacturing company." } \\
\text { Assuming that the pharmacist was indepen- } \\
\text { dent of the study team this was probably ad- } \\
\text { equate }\end{array}$ \\
\hline $\begin{array}{l}\text { Blinding? } \\
\text { Blinding of Participants }\end{array}$ & Low risk & $\begin{array}{l}\text { "...identical (colour and taste) placebo. Both } \\
\text { drug and placebo were prepared and dis- } \\
\text { pensed in a single dose amber coloured glass } \\
\text { ampoule by a local pharmaceutical com- } \\
\text { pany." }\end{array}$ \\
\hline
\end{tabular}

\begin{tabular}{l|l} 
Blinding? & Low risk \\
Blinding of provider &
\end{tabular}

"For keeping the trial totally blinded to all participants (for example, patients, investigators, surveyor), randomisation was done by a pharmacist of the drug manufacturing company. Samples of drug (or placebo) were identified by the code number of the respective child.”

Blinding? Low risk

Blinding of outcome assessor
"For keeping the trial totally blinded to all participants (for example, patients, investi- gators, surveyor), randomisation was done by a pharmacist of the drug manufacturing company. Samples of drug (or placebo) were identified by the code number of the respec- tive child."


Biswas 1994 (Continued)

\begin{tabular}{|c|c|c|}
\hline Incomplete outcome data addressed? & Low risk & $\begin{array}{l}\text { "....data was analysed for } 174 \text { children due } \\
\text { to attrition of } 6 \text { children for various reasons } \\
\text { (for example, } 5 \text { children were hospitalised } \\
\text { due to illnesses unrelated to the study ob- } \\
\text { jectives and the death of } 1 \text { child due post- } \\
\text { measles bronchopneumonia)." } \\
\text { Attrition was low and reported not to relate } \\
\text { to treatment. }\end{array}$ \\
\hline
\end{tabular}

Free of selective reporting? Unclear risk

Study protocol was not available to permit a clear judgement. Study aims were to measure diarrhoea and respiratory infection; both outcomes were reported in full in the study report. One child died and the treatment group assignment was not disclosed

Free of other bias?

Low risk

This study appears to be free of other bias.

Cheng 1993

\begin{tabular}{ll} 
Methods & This randomised trial was conducted in a rural area of China, Asia \\
\hline Participants & $\begin{array}{l}\text { Children aged } 6 \text { months to } 3 \text { years were eligible for inclusion in the trial } \\
\text { A total of } 198 \text { children were randomised either to vitamin A or placebo group. There were } \\
105 \text { children in vitamin A and } 81 \text { in placebo group. Mean age of children and proportion } \\
\text { of males were not specified in the study }\end{array}$ \\
\hline Interventions & $\begin{array}{l}\text { Vitamin A was supplemented in a dose of } 200000 \text { IU for children }>12 \text { months and } 100 \\
000 \text { IU for }<12 \text { months of age. Control group received placebo in the form of vegetable } \\
\text { oil. Interventions were given every } 4 \text { months for } 12 \text { months }\end{array}$ \\
\hline Outcomes & $\begin{array}{l}\text { Incidence of diarrhoea and respiratory disease, all-cause hospitalisations, diarrhoea specific } \\
\text { hospitalisations, pneumonia specific hospitalisations, mean vitamin A serum levels }\end{array}$ \\
\hline Notes & $\begin{array}{l}\text { Baseline serum levels of retinol were similar in both the groups. Measurement of bio- } \\
\text { chemical vitamin A levels in the study area fulfilled the WHO criteria for an action to be } \\
\text { triggered at a pubic health level. The morbidity surveillance was done twice a month }\end{array}$ \\
\hline
\end{tabular}

Risk of bias

\begin{tabular}{|c|c|c|}
\hline Bias & Authors' judgement & Support for judgement \\
\hline Adequate sequence generation? & Unclear risk & $\begin{array}{l}\text { " } 198 \text { children who were randomly assigned } \\
\text { on a } 3: 2 \text { allocation to treatment (105) and } \\
\text { control ( } 81 \text { ) groups." } \\
\text { No more information was provided about } \\
\text { sequence generation. }\end{array}$ \\
\hline
\end{tabular}

Vitamin A supplementation for preventing morbidity and mortality in children from 6 months to 5 years of age (Review) 
Cheng 1993 (Continued)

\begin{tabular}{|c|c|c|}
\hline Allocation concealment? & Unclear risk & $\begin{array}{l}\text { Insufficent information to permit judg- } \\
\text { ment. }\end{array}$ \\
\hline $\begin{array}{l}\text { Blinding? } \\
\text { Blinding of Participants }\end{array}$ & Low risk & $\begin{array}{l}\text { "Administration was double blind: neither } \\
\text { parents nor doctors knew whether the child } \\
\text { was in a treatment or control group." } \\
\text { Placebo capsules contained vegetable oil and } \\
\text { were likely to have been indistinguishable } \\
\text { from intervention }\end{array}$ \\
\hline $\begin{array}{l}\text { Blinding? } \\
\text { Blinding of provider }\end{array}$ & Low risk & $\begin{array}{l}\text { "Placebo capsules contained vegetable oil } \\
\text { and were likely to have been indistinguish- } \\
\text { able from intervention." } \\
\text { In view of the adequate blinding procedures, } \\
\text { performance bias was unlikely to have influ- } \\
\text { enced the results }\end{array}$ \\
\hline $\begin{array}{l}\text { Blinding? } \\
\text { Blinding of outcome assessor }\end{array}$ & Low risk & $\begin{array}{l}\text { "Data collected by doctors who were already } \\
\text { blind to treatment group assignment." }\end{array}$ \\
\hline Incomplete outcome data addressed? & High risk & $\begin{array}{l}\text { Reasons for loss to follow- up were not pro- } \\
\text { vided. The number randomised and those } \\
\text { reported after loss to follow- up do not } \\
\text { match }\end{array}$ \\
\hline Free of selective reporting? & Unclear risk & $\begin{array}{l}\text { Protocol of study was not available to permit } \\
\text { a clear judgement }\end{array}$ \\
\hline Free of other bias? & Low risk & This study appears to be free of other bias. \\
\hline
\end{tabular}

\section{Cherian 2003}

Methods Individually randomised trial conducted in Vellor, India, Asia

Participants

Infants aged 9-12 months were eligible for inclusion in the study. Participants with previous history of measles vaccination or an exanthematous illness, with moderate or severe malnutrition, clinical signs of vitamin A deficiency, known immune deficiency or on immunosuppressive therapy and those who had received blood or blood products in the previous 6 months were excluded

A total of 395 infants were randomised to either vitamin A or placebo group. There were 198 infants in vitamin A group and 197 in placebo. Mean age of participants was 9.8 months and proportion of males was $52 \%$

Interventions

Infants in experimental group received a single dose of vitamin A in a dose of 100000 IU. The control group received placebo only. Interventions were given out at the time of measles vaccination

Outcomes

Antibody response to measles vaccine.

Vitamin A supplementation for preventing morbidity and mortality in children from 6 months to 5 years of age (Review) 
Cherian 2003 (Continued)

The primary objective of the study was to measure the antibody response to measles vac-
cine when given with and without vitamin A. This study found no significant inhibitory
or enhancing influence on antibody response to measles vaccine when administered con-
comitantly with vitamin A

Risk of bias

\begin{tabular}{|c|c|c|}
\hline Bias & Authors' judgement & Support for judgement \\
\hline Adequate sequence generation? & Unclear risk & $\begin{array}{l}\text { "The infants who were immunized with } \\
\text { monovalent measles vaccine were randomly } \\
\text { assigned, in blocks of eight, to concom- } \\
\text { tantly receive } 100,000 \text { IU of Vitamin A } \\
\text { in arachis oil or a placebo containing car- } \\
\text { boxymethylcellulose prepared in the hospi- } \\
\text { tal pharmacy." } \\
\text { Authors do not specify the method of se- } \\
\text { quence generation. }\end{array}$ \\
\hline Allocation concealment? & Low risk & $\begin{array}{l}\text { "...arachis oil or a placebo containing car- } \\
\text { boxymethylcellulose prepared in the hospi- } \\
\text { tal pharmacy." } \\
\text { Probably done since hospital pharmacy was } \\
\text { responsible for preparing the order of vita- } \\
\text { min A and placebo and not likely to have } \\
\text { been internal to the study team }\end{array}$ \\
\hline $\begin{array}{l}\text { Blinding? } \\
\text { Blinding of Participants }\end{array}$ & Unclear risk & $\begin{array}{l}\text { "...Vitamin A in arachis oil or a placebo con- } \\
\text { taining carboxymethylcellulose..." } \\
\text { Insufficent information to permit judg- } \\
\text { ment. }\end{array}$ \\
\hline $\begin{array}{l}\text { Blinding? } \\
\text { Blinding of provider }\end{array}$ & Unclear risk & $\begin{array}{l}\text { Insufficent information to permit judg- } \\
\text { ment. }\end{array}$ \\
\hline $\begin{array}{l}\text { Blinding? } \\
\text { Blinding of outcome assessor }\end{array}$ & Unclear risk & $\begin{array}{l}\text { Insufficent information to permit judg- } \\
\text { ment. }\end{array}$ \\
\hline Incomplete outcome data addressed? & High risk & $\begin{array}{l}\text { The proportion of children providing ade- } \\
\text { quate samples is low at } 6 \text { months, and there } \\
\text { is insufficient detail about the reasons for } \\
\text { missing data }\end{array}$ \\
\hline
\end{tabular}

Free of selective reporting? High risk

There is no mention of mortality or any morbidity of measles or diarrhoea

Free of other bias? $\quad$ Unclear risk

Insufficent information to permit judgment.

Vitamin A supplementation for preventing morbidity and mortality in children from 6 months to 5 years of age (Review)

Copyright $\Subset 201$ I The Cochrane Collaboration. Published by John Wiley \& Sons, Ltd. 


\begin{tabular}{ll}
\hline Methods & Individually randomised trial conducted in urban slums of Chandigarh, India, Asia \\
\hline Participants & $\begin{array}{l}\text { Children aged less than } 10 \text { years were eligible for inclusion in the study. Children with } \\
\text { xerophthalmia and previous history of vitamin A supplementation were excluded } \\
\text { A total of } 1520 \text { children were randomised either to vitamin A or placebo group. There } \\
\text { were } 756 \text { children in vitamin A group and } 759 \text { in placebo group. Mean age of participants } \\
\text { was } 51 \text { months and proportion of males in study sample was } 50 \%\end{array}$ \\
\hline Interventions & $\begin{array}{l}\text { The experimental group received vitamin A in a of } 50 \text { 000 IU for children aged }<6 \text { months, } \\
100000 \text { IU for } 6-12 \text { months and } 200000 \text { for }>1 \text { year. The control group received placebo. }\end{array}$ \\
\hline The intervention was given every 4 months for 15 months
\end{tabular}

Risk of bias

\begin{tabular}{|c|c|c|}
\hline Bias & Authors' judgement & Support for judgement \\
\hline Adequate sequence generation? & Unclear risk & $\begin{array}{l}\text { "From three slums of Chandigarh, } 1520 \\
\text { non-xerophthalmic children of less than } 10 \\
\text { years of age were individually randomised } \\
\text { in equal number to receive vitamin A or } \\
\text { placebo." }\end{array}$ \\
\hline Allocation concealment? & Unclear risk & $\begin{array}{l}\text { Insufficent information to permit judg- } \\
\text { ment. }\end{array}$ \\
\hline $\begin{array}{l}\text { Blinding? } \\
\text { Blinding of Participants }\end{array}$ & Unclear risk & $\begin{array}{l}\text { "An equivalent volume of arachis oil was } \\
\text { given as placebo." } \\
\text { Insufficent information to permit judg- } \\
\text { ment. }\end{array}$ \\
\hline $\begin{array}{l}\text { Blinding? } \\
\text { Blinding of provider }\end{array}$ & Unclear risk & $\begin{array}{l}\text { Insufficent information to permit judg- } \\
\text { ment. }\end{array}$ \\
\hline $\begin{array}{l}\text { Blinding? } \\
\text { Blinding of outcome assessor }\end{array}$ & Unclear risk & $\begin{array}{l}\text { Insufficent information to permit judg- } \\
\text { ment. }\end{array}$ \\
\hline
\end{tabular}


Chowdhury 2002 (Continued)

\begin{tabular}{l|l|l}
\hline Incomplete outcome data addressed? & High risk & $\begin{array}{l}\text { Although attrition rates were balanced the } \\
\text { rates of mortality were lower than the rate } \\
\text { of withdrawal. This could impact on the re- } \\
\text { liability of the results }\end{array}$ \\
\hline Free of selective reporting? & Unclear risk & $\begin{array}{l}\text { Insufficent information to permit judg- } \\
\text { ment. }\end{array}$ \\
\hline Free of other bias? & Unclear risk & $\begin{array}{l}\text { Study not sufficiently reported in order to } \\
\text { assess this item fully }\end{array}$ \\
\hline
\end{tabular}

Daulaire 1992

\begin{tabular}{|c|c|}
\hline Methods & $\begin{array}{l}\text { A cluster randomised, non-placebo controlled trial conducted in Jumla district, Nepal, } \\
\text { Asia }\end{array}$ \\
\hline Participants & $\begin{array}{l}\text { Children 1-59 months were eligible for inclusion in the trial } \\
\text { A total of } 16 \text { clusters were randomly assigned either to vitamin A or control group. These } \\
\text { include a total of } 7197 \text { children in which } 3786 \text { children were in vitamin A group and } 3411 \\
\text { in control group. Proportion of male participants was } 51 \%\end{array}$ \\
\hline Interventions & $\begin{array}{l}\text { Children in experimental group received vitamin A in a dose of } 200000 \text { IU for children } \\
\text { aged } 12-59 \text { months, } 100000 \text { IU for those of } 6-12 \text { months and } 50000 \text { IU for }<6 \text { months } \\
\text { old. Vitamin A was supplemented once only and children were followed for } 5 \text { months }\end{array}$ \\
\hline Outcomes & All-cause mortality and cause specific mortality for diarrhoea, pneumonia and measles \\
\hline Notes & $\begin{array}{l}\text { The study site was a remote mountainous region of northwestern Nepal with a total } \\
\text { population of about } 80,000 \text {, with } 12,000 \text { children under } 5 \text { years of age. This area was } \\
\text { considered as one of the poorest and most medically underserved areas of the country. } \\
\text { Infant mortality rate was } 189 \text { deaths per } 1000 \text { live births and child (1-4 years) mortality } \\
\text { rate was } 52 \text { per } 1000 \text { per year. Malnutrition was prevalent in the study area, and } 26 \% \text { of } \\
\text { children aged } 1-4 \text { years were suffering from substantial malnutrition. A survey of } 3651 \\
\text { children in children under } 5 \text { years showed active xerophthalmia in } 1.3-2 \% \text { of population } \\
\text { and } 1-5 \% \text { among infants, which is high for this age group. Disaggregated data on mortality } \\
\text { was available according to different age groups. We have used data for children } 6-59 \\
\text { months according to the objectives of our review. According to WHO, Nepal is a country } \\
\text { with a high child mortality rate (i.e. }>40 / 1000 \text { ) }\end{array}$ \\
\hline
\end{tabular}

\section{Risk of bias}

\begin{tabular}{|c|c|c|}
\hline Bias & Authors' judgement & Support for judgement \\
\hline Adequate sequence generation? & Low risk & $\begin{array}{l}\text { "We randomly selected by card eight of the } \\
16 \text { sub-districts for vitamin A supplementa- } \\
\text { tion." } \\
\text { Probably done. }\end{array}$ \\
\hline
\end{tabular}

Vitamin A supplementation for preventing morbidity and mortality in children from 6 months to 5 years of age (Review) 
Daulaire 1992 (Continued)

\begin{tabular}{l|l|l}
\hline Allocation concealment? & High risk & $\begin{array}{l}\text { Author contacted and replied, "No effort } \\
\text { was made to conceal the allocation se- } \\
\text { quence." }\end{array}$ \\
\hline $\begin{array}{l}\text { Blinding? } \\
\text { Blinding of Participants }\end{array}$ & High risk & "There was no placebo or blinding." \\
\hline $\begin{array}{l}\text { Blinding? } \\
\text { Blinding of provider }\end{array}$ & High risk & "There was no placebo or blinding." \\
\hline $\begin{array}{l}\text { Blinding? } \\
\text { Blinding of outcome assessor }\end{array}$ & High risk & "There was no placebo or blinding." \\
\hline $\begin{array}{l}\text { Incomplete outcome data addressed? } \\
\text { Free of selective reporting? }\end{array}$ & Low risk & $\begin{array}{l}\text { There was no loss to follow- up. Coverage } \\
\text { of intervention was described in detail }\end{array}$ \\
\hline \begin{tabular}{l} 
Free of other bias? \\
\hline
\end{tabular} & Unclear risk & Insufficent information to permit judg- \\
\hline
\end{tabular}

\section{DEVTA 2007}

Methods

Participants

Interventions

Outcomes

Notes This study was not included, but some available data was used in a sensitivity analysis. See Characteristics of studies awaiting classification

\section{Dibley 1994}

Methods

Participants
Individually randomised trial conducted in 34 rural villages located on the southern coast of Central Java in Indonesia, Asia

Children aged 6 to 47 months were eligible for inclusion in the review. Children with cerebral palsy, epilepsy, flaccid paralysis, mental retardation, congenital or rheumatic heart disease were permanently excluded. Those with weight-for-height more than $3.00 \mathrm{SD}$ below the WHO growth reference mean or acute xerophthalmia were excluded for one cycle and treated with high dose vitamin $A$ and then included

A total of 1405 children were randomised to either vitamin A or placebo group. Proportion of male participants was $50.9 \%$ 
Dibley 1994 (Continued)

\begin{tabular}{ll} 
Interventions & $\begin{array}{l}\text { Intervention group received 206,000 IU of vitamin A in the form of retinyl ester plus } 37 \\
\text { IU vitamin E for children }>12 \text { months or 103,000 IU retinyl ester plus } 17 \text { IU vitamin E } \\
\text { if less than } 12 \text { months of age. The control group received placebo that contained } 17 \text { or } \\
37 \text { IU vitamin E according to the age of the subject. The intervention was given every } 4 \\
\text { months for } 24 \text { months. An average of } 89 \% \text { of the children received a treatment (vitamin } \\
\text { A or placebo) }\end{array}$ \\
\hline Outcomes & $\begin{array}{l}\text { All-cause mortality, incidence of diarrhoea and respiratory disease, mean vitamin A serum } \\
\text { level, proportion of vitamin A deficient, growth }\end{array}$ \\
\hline Notes & $\begin{array}{l}\text { Baseline demographic, clinical and nutritional characteristics of the participants were the } \\
\text { same, and the groups remained balance at the start of each of the other } 5 \text { cycles. Children } \\
\text { were visited every other day for } 6 \text { cycles. The longest recall period allowed was } 4 \text { days. } \\
\text { Observed child-days of ALRI of vitamin A group and control group were } 280,186 \text { and } \\
273,630 . \text { According to WHO, Indonesia is a country with a high child mortality rate (i. } \\
\text { e. }>40 / 1000)\end{array}$ \\
\hline
\end{tabular}

Risk of bias

\begin{tabular}{|c|c|c|}
\hline Bias & Authors' judgement & Support for judgement \\
\hline Adequate sequence generation? & Low risk & $\begin{array}{l}\text { "Randomization of the treatments was done } \\
\text { with a 1:1 allocation ratio in blocks of eight, } \\
\text { based on a table of random permutations of } \\
\text { integers (Cochrane and Cox 1950)." } \\
\text { Likely to be adequate. }\end{array}$ \\
\hline Allocation concealment? & Low risk & $\begin{array}{l}\text { "All investigators, field and laboratory staff, } \\
\text { and participants were masked to the treat- } \\
\text { ment code." } \\
\text { "The capsules were packaged in opaque blis- } \\
\text { ter packs with a unique treatment code." }\end{array}$ \\
\hline $\begin{array}{l}\text { Blinding? } \\
\text { Blinding of Participants }\end{array}$ & Low risk & $\begin{array}{l}\text { "The oily contents of the vitamin A and } \\
\text { placebo capsules were of similar taste and } \\
\text { colour." }\end{array}$ \\
\hline $\begin{array}{l}\text { Blinding? } \\
\text { Blinding of provider }\end{array}$ & Low risk & $\begin{array}{l}\text { "All investigators, field and laboratory staff, } \\
\text { and participants were masked to the treat- } \\
\text { ment code." } \\
\text { Adequate allocation concealment and the } \\
\text { identical presentation of placebo and vita- } \\
\text { min A should have prevented providers be- } \\
\text { coming unblinded to treatment group as- } \\
\text { signment. Low risk of performance bias }\end{array}$ \\
\hline $\begin{array}{l}\text { Blinding? } \\
\text { Blinding of outcome assessor }\end{array}$ & Low risk & $\begin{array}{l}\text { "All investigators, field and laboratory staff, } \\
\text { and participants were masked to the treat- }\end{array}$ \\
\hline
\end{tabular}

Vitamin A supplementation for preventing morbidity and mortality in children from 6 months to 5 years of age (Review)

Copyright @ 201 I The Cochrane Collaboration. Published by John Wiley \& Sons, Ltd. 


\begin{tabular}{|c|c|c|}
\hline & & $\begin{array}{l}\text { ment code." } \\
\text { Adequate allocation concealment and the } \\
\text { identical presentation of placebo and vita- } \\
\text { min A should have prevented outcome as- } \\
\text { sessors becoming unblinded to treatment } \\
\text { group assignment }\end{array}$ \\
\hline Incomplete outcome data addressed? & Low risk & $\begin{array}{l}\text { Complete details of those excluded and lost } \\
\text { to follow-up with reason were described. } \\
\text { There were a low and balanced number of } \\
\text { withdrawals between the treatment groups. } \\
\text { The analytical method took account of the } \\
\text { time on treatment (i.e. follow-up time for } \\
\text { each cycle) and this may have been adequate }\end{array}$ \\
\hline Free of selective reporting? & Low risk & $\begin{array}{l}\text { Lack of trial protocol hinders full assessment } \\
\text { of this item. However, data on outcomes of } \\
\text { relevance to the review were reported }\end{array}$ \\
\hline Free of other bias? & Low risk & This study appears to be free of other bias. \\
\hline
\end{tabular}

Donnen 1998

Methods

Individually randomised, non-placebo controlled trial conducted in South Kivu province of Congo, Africa

Participants

Children 0-72 months were eligible for inclusion in the trial. Children were recruited as soon they were discharged from children hospital Kotive. No exclusion criteria was described

A total of 358 children were randomly assigned to vitamin A, mebendazole, or control group. Vitamin A had 118 children and control group had 117

Interventions

There were three study groups. The first group was supplemented with vitamin A, second group received mebendazole for deworming and third group was simply observed as control. Children in vitamin A group received retinol palmitate in a dose of $100000 \mathrm{IU}$ for children aged $<1$ year and 200000 IU for those $>1$ year. Supplementation was repeated after 6 months and continued for 12 months

Outcomes

All-cause mortality, growth and incidence of diarrhoea and respiratory disease morbidity

Notes

Morbidity surveillance was done every 2 weeks during 3 months, then every 3 months until 12 months. Data on morbidity outcomes were presented in the form of odds ratios based on generalised estimating equation models. As we were using the data in the form of relative risk and no nominators were given in this study, we could not pool the data for diarrhoea and respiratory morbidity of this study

Risk of bias

Vitamin A supplementation for preventing morbidity and mortality in children from 6 months to 5 years of age (Review) 
Donnen 1998 (Continued)

\begin{tabular}{|c|c|c|}
\hline Bias & Authors' judgement & Support for judgement \\
\hline Adequate sequence generation? & Unclear risk & $\begin{array}{l}\text { "As soon as the children were discharged } \\
\text { from the hospital, they were randomly as- } \\
\text { signed to one of the three groups." } \\
\text { Probably not done }\end{array}$ \\
\hline Allocation concealment? & Unclear risk & $\begin{array}{l}\text { Insufficient details available to make a judg- } \\
\text { ment. }\end{array}$ \\
\hline $\begin{array}{l}\text { Blinding? } \\
\text { Blinding of Participants }\end{array}$ & Unclear risk & $\begin{array}{l}\text { Insufficient details available to make a judg- } \\
\text { ment. }\end{array}$ \\
\hline $\begin{array}{l}\text { Blinding? } \\
\text { Blinding of provider }\end{array}$ & Unclear risk & $\begin{array}{l}\text { Insufficient details available to make a judg- } \\
\text { ment. }\end{array}$ \\
\hline $\begin{array}{l}\text { Blinding? } \\
\text { Blinding of outcome assessor }\end{array}$ & Unclear risk & $\begin{array}{l}\text { Insufficient details available to make a judg- } \\
\text { ment. }\end{array}$ \\
\hline Incomplete outcome data addressed? & Low risk & $\begin{array}{l}\text { Authors indicate that } 6 \% \text { were lost to fol- } \\
\text { low- up, not discussed in detail. Number } \\
\text { died but not indicated how or by group data. } \\
\text { Overall, } 6 \% \text { of the children were lost to fol- } \\
\text { low-up, with approximately equal propor- } \\
\text { tions in each group }\end{array}$ \\
\hline Free of selective reporting? & Unclear risk & $\begin{array}{l}\text { Insufficient details available to make a judg- } \\
\text { ment. }\end{array}$ \\
\hline Free of other bias? & Low risk & This study appears to be free of other bias. \\
\hline
\end{tabular}

\section{Florentino 1990}

Methods

Individually randomised trial conducted in the municipalities of Pililla and Binangonan in the province of Rizal, Philippines, Asia

Participants

Children 1-6 years of age were eligible for inclusion in the study. Any child with clinical signs of vitamin A deficiency was excluded from the trial

A total of 2471 children were randomised to three intervention groups. Mean age of children was 3.4 years and proportion of males in study population was $49.5 \%$

Interventions

There were 3 study groups, 2 were supplemented with vitamin A and 1 with placebo. The first group in the experimental group received a high dose of vitamin A i.e. $200000 \mathrm{IU}$ and the second group received a medium dose of vitamin A i.e. $100000 \mathrm{IU}$. The control group received placebo only. Children were supplemented only once and were followed for 1 week 
Florentino 1990 (Continued)

\begin{tabular}{ll}
\hline Outcomes & $\begin{array}{l}\text { Incidence of side effects within } 1 \text { week: nausea and/or vomiting, headache, diarrhoea and } \\
\text { fever }\end{array}$ \\
\hline Notes & $\begin{array}{l}\text { The study area had a high prevalence of malnutrition, and therefore vitamin A deficiency } \\
\text { was likely to be prevalent. Study reported outcome for first } 48 \text { hours and within a week. } \\
\text { We have pooled the data for first week }\end{array}$ \\
\hline
\end{tabular}

Risk of bias

\begin{tabular}{lll}
\hline Bias & Authors' judgement & Support for judgement \\
\hline Adequate sequence generation? & Unclear risk & $\begin{array}{l}\text { "By use of a double-blind study design, chil- } \\
\text { dren were randomly assigned to three treat- } \\
\text { ment groups." } \\
\text { No qualifying information on what 'ran- } \\
\text { domly assigned' means is provided. Difficult } \\
\text { to assess sequence generation }\end{array}$ \\
\hline Allocation concealment? & Unclear risk & $\begin{array}{l}\text { Insufficient details available to make a judg- } \\
\text { ment. }\end{array}$ \\
\hline $\begin{array}{l}\text { Blinding? } \\
\text { Blinding of Participants }\end{array}$ & Low risk & $\begin{array}{l}\text { "Neither the researchers and field workers } \\
\text { nor the subjects knew the contents of the } \\
\text { preparations; the code was kept confidential } \\
\text { by Hoffman La Roche until after the analysis } \\
\text { of the results was completed." }\end{array}$ \\
\hline
\end{tabular}

Blinding? Low risk

Blinding of provider

Blinding?

Blinding of outcome assessor

Low risk

Incomplete outcome data addressed? Low risk

Free of selective reporting?

Low risk
"Neither the researchers and field workers nor the subjects knew the contents of the preparations; the code was kept confidential by Hoffman La Roche until after the analysis of the results was completed."

Blinding adequate and performance bias unlikely to have influenced results

"Neither the researchers and field workers nor the subjects knew the contents of the preparations; the code was kept confidential by Hoffman La Roche until after the analysis of the results was completed."

Complete details of those excluded and lost to follow-up were provided. Only 76 children lost, differences slight between groups

Though not explicitly stated all reported measured outcomes have data reported in results with sufficient clarity and explana- 


\begin{tabular}{l|l}
\hline Free of other bias? & Low risk $\quad$ No other apparent bias was noted.
\end{tabular}

\section{Herrera 1992}

\begin{tabular}{ll} 
Methods & Cluster randomised trial was conducted in five rural councils in northern Sudan, Africa \\
\hline Participants & $\begin{array}{l}\text { Eligibily criteria was age 9-72 months. Children with xerophthalmia were excluded } \\
\text { Randomisation was done by households. Study included a total of } 28,753 \text { children of } \\
\text { whom } 14,343 \text { were in vitamin A group and } 14,149 \text { were in placebo group. Proportion of } \\
\text { male children in the study was } 50.7 \%\end{array}$ \\
\hline
\end{tabular}

$\begin{array}{ll}\text { Interventions } & \text { Children in vitamin A group received } 200000 \text { IU of retinol palmitate along with } 40 \text { IU } \\ \text { of vitamin E. The comparison group received } 40 \text { IU of vitamin E only. The intervention } \\ \text { was given every six months for } 18 \text { months }\end{array}$

Outcomes

Outcomes

\begin{tabular}{ll}
\hline Notes & $\begin{array}{l}\text { Authors used non- specific terms for describing cause of death (in table 4) like "shortness of } \\
\text { breath" "convulsions" and "fever" etc. We have pooled data for "shortness of breath" under } \\
\text { heading of lower respiratory tract infection mortality. This is because it is highly unlikely } \\
\text { that a child will die of an upper respiratory tract infection and lower respiratory tract } \\
\text { infection is a more general term than pneumonia to cover this as it includes pneumonia as } \\
\text { well. According to WHO, Sudan is a country with a high child mortality rate (i.e. }>40 / \\
1000)\end{array}$ \\
\hline
\end{tabular}

All-cause mortality and cause specific mortality of diarrhoea, measles, respiratory disease. Incidence of diarrhoea, respiratory disease and measles. Incidence of xeropthalmia, Bitot's spots and night blindness

\section{Risk of bias}

\begin{tabular}{|c|c|c|}
\hline Bias & Authors' judgement & Support for judgement \\
\hline Adequate sequence generation? & High risk & $\begin{array}{l}\text { "Randomisation was done by household. } \\
\text {.. Assignment to treatment group was } \\
\text { achieved by the two interviewers visiting al- } \\
\text { ternate households throughout the village. } \\
\text { All eligible children in alternate households } \\
\text { were assigned to receive, every } 6 \text { months, } \\
\text { either a capsule of } 60 \mathrm{mg}(200000 \mathrm{IU}) \text { of } \\
\text { vitamin A and } 40 \mathrm{mg}(40 \mathrm{IU}) \text { of vitamin E } \\
\text { or a capsule of } 40 \mathrm{mg} \text { of vitamin E without } \\
\text { vitamin A." } \\
\text { Does not appear to be randomised. }\end{array}$ \\
\hline Allocation concealment? & Unclear risk & $\begin{array}{l}\text { Insufficient details available to make a judg- } \\
\text { ment. }\end{array}$ \\
\hline
\end{tabular}

Vitamin A supplementation for preventing morbidity and mortality in children from 6 months to 5 years of age (Review)

Copyright $\odot 201$ I The Cochrane Collaboration. Published by John Wiley \& Sons, Ltd. 


\section{Herrera 1992 (Continued)}

\begin{tabular}{|c|c|c|}
\hline $\begin{array}{l}\text { Blinding? } \\
\text { Blinding of Participants }\end{array}$ & Low risk & $\begin{array}{l}\text { "The capsules were colour-coded to avoid } \\
\text { the possibility of mix ups, but none of the } \\
\text { study team members was aware which was } \\
\text { the experimental capsule and which was the } \\
\text { placebo until the end of data collection. } \\
\text { All eligible children in a household received } \\
\text { capsules of the same colour." }\end{array}$ \\
\hline $\begin{array}{l}\text { Blinding? } \\
\text { Blinding of provider }\end{array}$ & Low risk & $\begin{array}{l}\text { "The capsules were colour-coded to avoid } \\
\text { the possibility of mix ups, but none of the } \\
\text { study team members was aware which was } \\
\text { the experimental capsule and which was the } \\
\text { placebo until the end of data collection. } \\
\text { All eligible children in a household received } \\
\text { capsules of the same colour." } \\
\text { Performance bias unlikely given that trialists } \\
\text { and staff were blinded during the interven- } \\
\text { tion }\end{array}$ \\
\hline
\end{tabular}

\begin{tabular}{l|l}
\hline Blinding? & Low risk \\
Blinding of outcome assessor & \\
\hline
\end{tabular}

"Only the manufacturer knew the contents of the capsules until after data collection and preliminary analysis of the results."

Probably done.

Incomplete outcome data addressed? Low risk

3320 children did not receive 1 or 2 of the 3 vitamin A or placebo capsules. Most of this non-compliant group consisted of children absent from the household at the time of follow-up, whereas others had moved away or refused to take part further. As a group, the non-compliant children tended to be from poorer households than those who continued in the study. However, there were no significant differences between vitamin $\mathrm{A}$ and placebo groups in the number of non-compliant subjects or in their ages, sex, or nutritional status

With respect to the variables relevant to the intervention, the losses to follow- up were not significantly different from those that remained in the study

Free of selective reporting? Unclear risk

Does not reference a protocol or trial registration and does not state that all measured outcomes are reported ment. 
Kartasasmita 1995

\begin{tabular}{ll} 
Methods & $\begin{array}{l}\text { Individually randomised trial conducted in a suburban community of city Bandung, In- } \\
\text { donesia, Asia }\end{array}$ \\
\hline Participants & $\begin{array}{l}\text { Children aged } 12-54 \text { months were included in the study. No exclusion criteria was specified } \\
\text { A total of } 269 \text { children were randomised either to vitamin A or placebo group. Vitamin A } \\
\text { supplemented group had } 126 \text { children while placebo group had } 141 \text { children. Mean age } \\
\text { of study participants was } 33 \text { months and proportion of males was } 51 \%\end{array}$ \\
\hline Interventions & $\begin{array}{l}\text { The experimental group received } 200000 \text { IU of vitamin A once every } 6 \text { months for } 12 \\
\text { months. The comparison group received placebo only }\end{array}$ \\
\hline Outcomes & Incidence of respiratory disease. Mean serum retinol levels. \\
\hline Notes & $\begin{array}{l}\text { Authors presented data on respiratory outcomes according to severity of disease. We have } \\
\text { included data for "severe respiratory disease" only }\end{array}$
\end{tabular}

\section{Risk of bias}

\begin{tabular}{|c|c|c|}
\hline Bias & Authors' judgement & Support for judgement \\
\hline Adequate sequence generation? & Unclear risk & $\begin{array}{l}\text { "The children were selected by randomised } \\
\text { stratified sampling from the almost } 2000 \\
\text { under-fives residing in Cikutra." } \\
\text { Insufficient details available to make a judg- } \\
\text { ment. }\end{array}$ \\
\hline Allocation concealment? & Unclear risk & $\begin{array}{l}\text { Insufficient detail provided to make judge- } \\
\text { ment. }\end{array}$ \\
\hline $\begin{array}{l}\text { Blinding? } \\
\text { Blinding of Participants }\end{array}$ & Unclear risk & $\begin{array}{l}\text { "All children participated in an age- and sex- } \\
\text { matched randomised, double blind vitamin } \\
\text { A supplementation programme by receiving } \\
\text { vitamin A } 200,000 \text { IU or placebo capsules } \\
\text { orally, at the start and at the 6th month of } \\
\text { the study." }\end{array}$ \\
\hline $\begin{array}{l}\text { Blinding? } \\
\text { Blinding of provider }\end{array}$ & Unclear risk & $\begin{array}{l}\text { Insufficient detail provided to make judge- } \\
\text { ment. }\end{array}$ \\
\hline $\begin{array}{l}\text { Blinding? } \\
\text { Blinding of outcome assessor }\end{array}$ & Unclear risk & $\begin{array}{l}\text { Insufficient detail provided to make judge- } \\
\text { ment. }\end{array}$ \\
\hline Incomplete outcome data addressed? & High risk & $\begin{array}{l}\text { Insufficient reporting of attrition/exclusions } \\
\text { to permit judgement }\end{array}$ \\
\hline Free of selective reporting? & Unclear risk & $\begin{array}{l}\text { Insufficient detail provided to make judge- } \\
\text { ment. }\end{array}$ \\
\hline
\end{tabular}


Kartasasmita 1995 (Continued)

\begin{tabular}{|c|c|c|}
\hline Free of other bias? & Unclear risk & $\begin{array}{l}\text { The methods of the study are not described } \\
\text { very clearly. }\end{array}$ \\
\hline
\end{tabular}

Lima 2010

\begin{tabular}{ll} 
Methods & $\begin{array}{l}\text { Individually randomised trial conducted in Fortaleza, the capital of the Ceara state in } \\
\text { northeastern Brazil, Latin America }\end{array}$ \\
\hline Participants & $\begin{array}{l}\text { Children aged } 2 \text { months to } 9 \text { years were eligible for inclusion in the study. Those partici- } \\
\text { pants who had fever }>38 \mathrm{C} \text { or exclusively breastfed were excluded } \\
\text { A total of } 79 \text { children were randomised either to vitamin A or placebo group. There were } \\
39 \text { participants in vitamin A group and } 40 \text { in placebo. Mean age of participants was } 43.3 \\
\text { months and proportion of males was } 57 \%\end{array}$
\end{tabular}

Interventions

Retinol palmitate was supplemented in a dose of 100000 IU for children aged $<12$ months and $200000 \mathrm{IU}>12$ months in experimental group. The comparison group received Tocopherol (vitamin E) as placebo. Supplements were given at enrolment, 4 and 8 months

\begin{tabular}{ll}
\hline Outcomes & Mean serum retinol levels, growth and adverse reactions to vitamin A \\
\hline Notes & $\begin{array}{l}\text { The infant mortality rate in study are was } 35 / 1000 \text { live births. The primary objective of } \\
\text { the study was to measure the effect of vitamin A on barrier function of gastrointestinal } \\
\text { tract. The study concluded that the prevalence of new parasitic infection, especially with } \\
\text { Giardia species, was significantly decreased with vitamin A intervention, suggesting an } \\
\text { immune regulatory modulation of this nutrient on parasitic intestinal infections }\end{array}$ \\
\hline
\end{tabular}

Risk of bias

\begin{tabular}{l|l|l}
\hline Bias & Authors' judgement & Support for judgement \\
\hline Adequate sequence generation? & Low risk & $\begin{array}{l}79 \text { children were randomly selected (using } \\
\text { computer-generated random numbers) }\end{array}$ \\
\hline Allocation concealment? & Unclear risk & $\begin{array}{l}\text { Insufficient detail provided to make judge- } \\
\text { ment. }\end{array}$ \\
\hline $\begin{array}{l}\text { Blinding? } \\
\text { Blinding of Participants }\end{array}$ & Low risk & $\begin{array}{l}\text { The parent or guardian of the children, field } \\
\text { study team, and investigators were blinded } \\
\text { to treatment agent }\end{array}$ \\
\hline
\end{tabular}

Blinding? Low risk

Blinding of provider

Blinding?

Blinding of outcome assessor
Low risk
The parent or guardian of the children, field study team, and investigators were blinded to treatment agent

The parent or guardian of the children, field study team, and investigators were blinded to treatment agent 
Lima 2010 (Continued)

Indication that field study teams assessed outcomes. They were blinded

Incomplete outcome data addressed? Low risk

After 12-month follow-up, a total of 22 children were withdrawn from the study for the following reasons: change of address (16), parents or guardians did not co-operate with the study (5), and 1 had above the median $\mathrm{z}$ score for length or height at the time of the study initiation. The percentage of participants completing the study at 12 months was $72.2 \%$

Free of selective reporting? High risk

The objective of study also included reporting of diarrhoea. Authors had reported the overall incidence of diarrhoea in the whole population but the figures had been presented in a way that they can not be used in the meta-analysis

Free of other bias?

Low risk

No other apparent bias was observed.

Lin 2008

Methods

This study was described as randomised, placebo-controlled trial conducted in Wuhan, an industrial centre in central region of China, Asia

Participants

Inlcusion criteria was age 2 to 7 years. children were recruited from kindergarten in the area. Those who had fever, diarrhoea or a recent preventive injection were excluded from the study. Underweight children with BMI age- and sex- specific 5th percentile of the first US National Health and Nutrition Examination Survey data were excluded. Children whose protein or energy intake of Chinese RDA were also excluded

A total of 105 children were randomised to three intervention groups (described below) . Mean age of study participants was 55 months and proportion of male participants was $61 \%$

Interventions

There were 3 study groups. Two of these consisted of children who were vitamin A deficient and 1 with children who were vitamin A sufficient. Vitamin A was given only to 1 of the group of vitamin A deficient children in a dose of 100000 IU every month for three months. The rest of two groups received placebo

Outcomes

All-cause mortality, mean serum vitamin A levels.

Notes

In this review we have included data for vitamin A deficient children who were either supplemented with vitamin A or placebo. According to WHO, China does not have a high child mortality rate (i.e. $<40 / 1000$ )

\section{Risk of bias}

Vitamin A supplementation for preventing morbidity and mortality in children from 6 months to 5 years of age (Review)

Copyright $\odot 201$ I The Cochrane Collaboration. Published by John Wiley \& Sons, Ltd. 
Lin 2008 (Continued)

\begin{tabular}{|c|c|c|}
\hline Bias & Authors' judgement & Support for judgement \\
\hline Adequate sequence generation? & Unclear risk & $\begin{array}{l}\text { "The remaining } 70 \text { vitamin A-deficient } \\
\text { children were randomly and equally di- } \\
\text { vided into vitamin A deficient-supple- } \\
\text { mented group and vitamin A-deficient } \\
\text { placebo group." } \\
\text { The term 'randomised' is also used to de- } \\
\text { scribe a 3rd group that is clearly matched. } \\
\text { This may not be a RCT }\end{array}$ \\
\hline Allocation concealment? & Unclear risk & $\begin{array}{l}\text { Insufficient detail provided to make judge- } \\
\text { ment. }\end{array}$ \\
\hline $\begin{array}{l}\text { Blinding? } \\
\text { Blinding of Participants }\end{array}$ & Low risk & $\begin{array}{l}\text { "Children of vitamin A-deficient-supple- } \\
\text { mented group were given } 100000 \text { IU } \\
\text { (retinol equivalent) vitamin A capsules ev- } \\
\text { ery } 2 \text { weeks for } 3 \text { months (Grubesic, 2004) } \\
\text {. Children of vitamin A-sufficient placebo } \\
\text { group and vitamin A-deficient placebo } \\
\text { group received placebo capsules in the same } \\
\text { way." }\end{array}$ \\
\hline $\begin{array}{l}\text { Blinding? } \\
\text { Blinding of provider }\end{array}$ & Unclear risk & $\begin{array}{l}\text { Although study was double randomised trial } \\
\text { but no details of how blinding was achieved } \\
\text { was described in the district }\end{array}$ \\
\hline $\begin{array}{l}\text { Blinding? } \\
\text { Blinding of outcome assessor }\end{array}$ & Unclear risk & $\begin{array}{l}\text { Insufficient detail provided to make judge- } \\
\text { ment. }\end{array}$ \\
\hline Incomplete outcome data addressed? & Low risk & No attrition reported. \\
\hline Free of selective reporting? & High risk & $\begin{array}{l}\text { Main outcome data are not reported in a } \\
\text { manner that can be analysed }\end{array}$ \\
\hline Free of other bias? & Unclear risk & $\begin{array}{l}\text { As blinding is not described, potential per- } \\
\text { formance bias and other sources of bias can- } \\
\text { not be assessed }\end{array}$ \\
\hline
\end{tabular}

Lin 2009

Methods

Participants
Individual randomised trial conducted in rural China, Asia.

Children age 6 months to 7 years were included in the study. Those without informed consent or with acute and chronic diseases were excluded.

A total of 132 children were randomly allocated to three intervention groups. Mean age of children was 36.5 months and proportion of males was $50 \%$ 
Lin 2009 (Continued)

\begin{tabular}{ll}
\hline Interventions & $\begin{array}{l}\text { The three intervention groups included vitamin A, beta-carotene and placebo. The ex- } \\
\text { perimental group received } 100000 \text { IU of vitamin A every month for } 3 \text { months. Placebo } \\
\text { group received biscuits }\end{array}$ \\
\hline Outcomes & Mean vitamin A serum levels \\
\hline Notes & We have included the results for vitamin A group versus placebo only \\
\hline
\end{tabular}

Risk of bias

\begin{tabular}{|c|c|c|}
\hline Bias & Authors' judgement & Support for judgement \\
\hline Adequate sequence generation? & Low risk & $\begin{array}{l}\text { "The } 50 \text { severe vitamin A deficient chil- } \\
\text { dren and } 82 \text { marginal vitamin A deficient } \\
\text { children were randomly divided into three } \\
\text { groups respectively by using a table with ran- } \\
\text { domly assorted digits." } \\
\text { Probably done. }\end{array}$ \\
\hline
\end{tabular}

Allocation concealment? Unclear risk

No methods of allocation concealment are described in the text

\begin{tabular}{|c|c|c|}
\hline $\begin{array}{l}\text { Blinding? } \\
\text { Blinding of Participants }\end{array}$ & High risk & $\begin{array}{l}\text { "Vitamin A intervening group were admin- } \\
\text { istered 100,000 IU vitamin A capsules...the } \\
\text { beta-carotene intervening group...was ad- } \\
\text { ministered } 4 \mathrm{mg} \text { purified beta-carotene... } \\
\text { dissolved in vegetable oil and dropped into } \\
\text { a general little biscuit...the placebo group } \\
\text { were just administered a general little bis- } \\
\text { cuit." } \\
\text { Vitamin A and placebo were administered in } \\
\text { two different forms. Vitamin A was admin- } \\
\text { istered in capsule form while placebo was } \\
\text { given in the form of biscuits }\end{array}$ \\
\hline $\begin{array}{l}\text { Blinding? } \\
\text { Blinding of provider }\end{array}$ & High risk & $\begin{array}{l}\text { Vitamin A and placebo were administered in } \\
\text { two different forms. Vitamin A was admin- } \\
\text { istered in capsule form while placebo was } \\
\text { given in the form of biscuits }\end{array}$ \\
\hline $\begin{array}{l}\text { Blinding? } \\
\text { Blinding of outcome assessor }\end{array}$ & High risk & $\begin{array}{l}\text { Vitamin A and placebo were administered in } \\
\text { two different forms. Vitamin A was admin- } \\
\text { istered in capsule form while placebo was } \\
\text { given in the form of biscuits }\end{array}$ \\
\hline Incomplete outcome data addressed? & Low risk & $\begin{array}{l}\text { No dropouts reported, and numbers at base- } \\
\text { line and follow-up appear to be the same }\end{array}$ \\
\hline
\end{tabular}


Lin 2009 (Continued)

\begin{tabular}{l|ll} 
Free of selective reporting? & High risk & $\begin{array}{l}\text { Use of clinic services, hospitalisation, cause } \\
\text { specific morbidity not reported }\end{array}$ \\
\hline Free of other bias? & Low risk & This study appears to be free of other bias.
\end{tabular}

\section{Long 2006}

Methods

Participants
Factorial design, individually randomised trial conducted in La Magdalena Atlicpac, Mexico, North America

Children aged 6 to 15 months were eligible for inclusion in the review. Children who were suffering from diseases causing immunosuppression and any congenital or acquired alteration of the digestive tract that could alter the absorption of micronutrients, were excluded. Children who were taking vitamin supplements were also excluded from the study.

A total of 786 children were randomised to four intervention groups. Mean age of participants was 9.8 months. The proportion of males in study population was $51.7 \%$

Interventions

The four intervention groups were as follows:

1) Vitamin A group that received 20,000 IU retinol every 2 months for children aged $<1$ year or 45,000 IU for children aged > 1 year.

2) $\mathrm{Zn}$ group that received a daily dose equivalent to $20 \mathrm{mg}$ elemental $\mathrm{Zn}$ as zinc methionine

3) A group that received both the zinc supplement and the vitamin $A$ as above

4) A placebo group

Interventions were delivered every 2 months for 12 months.

Diarrhoea and respiratory disease morbidity.

Outcomes

We have included data of this factorial design trial in two sets. First data set give comparisons for vitamin A vs. placebo and the second set includes data for vitamin A + Zinc vs. zinc only. Data on respiratory morbidity was given with three definitions. We have pooled the data for "cough + difficulty breathing" under the heading of lower respiratory tract infection

\section{Risk of bias}

\begin{tabular}{|c|c|c|}
\hline Bias & Authors' judgement & Support for judgement \\
\hline Adequate sequence generation? & Low risk & $\begin{array}{l}\text { "The randomisation sequence was gener- } \\
\text { ated by using a random-number table by } \\
\text { project personnel from CENSIA, a division } \\
\text { of the Mexican Ministry of Health." }\end{array}$ \\
\hline Allocation concealment? & Low risk & $\begin{array}{l}\text { "These solutions were packaged in con- } \\
\text { secutively numbered, colour-coded, opaque } \\
\text { plastic droplet bottles to ensure that field } \\
\text { personnel and the principal investigator }\end{array}$ \\
\hline
\end{tabular}

Vitamin A supplementation for preventing morbidity and mortality in children from 6 months to 5 years of age (Review) 
Long 2006 (Continued)

were blinded."

\begin{tabular}{|c|c|c|}
\hline $\begin{array}{l}\text { Blinding? } \\
\text { Blinding of Participants }\end{array}$ & Low risk & $\begin{array}{l}\text { "The vitamin A, zinc, and vitamin A + zinc } \\
\text { supplements were prepared by personnel at } \\
\text { the National Institute of Nutrition in 5-mL } \\
\text { solutions that were similar in taste and ap- } \\
\text { pearance." }\end{array}$ \\
\hline $\begin{array}{l}\text { Blinding? } \\
\text { Blinding of provider }\end{array}$ & Low risk & $\begin{array}{l}\text { "This double-blind randomised trial ... } \\
\text { These solutions were packaged in consecu- } \\
\text { tively numbered, color-coded, opaque plas- } \\
\text { tic droplet bottles to ensure that field per- } \\
\text { sonnel and the principal investigator were } \\
\text { blinded." }\end{array}$ \\
\hline $\begin{array}{l}\text { Blinding? } \\
\text { Blinding of outcome assessor }\end{array}$ & Low risk & $\begin{array}{l}\text { "This double-blind randomised trial ... } \\
\text { These solutions were packaged in consecu- } \\
\text { tively numbered, color-coded, opaque plas- } \\
\text { tic droplet bottles to ensure that field per- } \\
\text { sonnel and the principal investigator were } \\
\text { blinded." } \\
\text { Probably done. }\end{array}$ \\
\hline
\end{tabular}

Incomplete outcome data addressed? Low risk

Lost to follow-up data given along with reasons for lost to follow-up. Ninety-three children were lost to follow-up or were excluded

Free of selective reporting? Unclear risk

Study protocol not available so can not assess or make any judgement

Free of other bias?

Low risk

This study appears to be free of other bias.

Long 2006 (2)

Methods

Participants

Interventions

Outcomes

Notes As Long 2006 above.

Vitamin A supplementation for preventing morbidity and mortality in children from 6 months to 5 years of age (Review) 


\begin{tabular}{ll} 
Methods & Individually randomised trial conducted in Mexico, North America \\
\hline Participants & $\begin{array}{l}\text { Children } 5-15 \text { months were eligible for inclusion in the trial. Those who were immuno- } \\
\text { suppressed, had any congenital abnormality or chronic diarrhoea were excluded. Those } \\
\text { who had a history of vitamin A supplementation were also excluded } \\
\text { A total of } 195 \text { children were randomised in which } 97 \text { were in vitamin A group and } 98 \text { in } \\
\text { placebo group. The proportion of males study population was } 49.7 \%\end{array}$ \\
\hline Interventions & $\begin{array}{l}\text { The experimental group received vitamin A in a dose of } 20,000 \text { IU for those aged }<12 \\
\text { months and } 45,000 \text { IU for those }>12 \text { months. Intervention was repeated every } 2 \text { months } \\
\text { for } 12 \text { months }\end{array}$ \\
\hline Outcomes & \begin{tabular}{l} 
Incidence of diarrhoea and respiratory disease. \\
\hline Notes
\end{tabular} \\
$\begin{array}{l}\text { The baseline socio-demographic characteristics of study children and households were } \\
\text { similar between children who received vitamin A and those who were given the placebo. } \\
\text { Children received monthly visits and referrals to the doctor, which appeared to exceed } \\
\text { normal treatment }\end{array}$
\end{tabular}

\section{Risk of bias}

\begin{tabular}{|c|c|c|}
\hline Bias & Authors' judgement & Support for judgement \\
\hline Adequate sequence generation? & Low risk & $\begin{array}{l}\text { "The randomisation sequence was gener- } \\
\text { ated by project personnel based at the } \mathrm{Na} \text { - } \\
\text { tional Institute of Public Health." } \\
\text { Probably done. }\end{array}$ \\
\hline Allocation concealment? & Low risk & $\begin{array}{l}\text { Personnel at the National Institute of Nutri- } \\
\text { tion carried out the preparation of the sup- } \\
\text { plements to assure that field personnel and } \\
\text { the principal investigator were unaware of } \\
\text { treatment regimen. Children in the vitamin } \\
\text { A and placebo groups received a } 5 \mathrm{ml} \mathrm{solu-} \\
\text { tion, from identical opaque plastic droplet } \\
\text { bottles numbered consecutively, adminis- } \\
\text { tered by the field team }\end{array}$ \\
\hline $\begin{array}{l}\text { Blinding? } \\
\text { Blinding of Participants }\end{array}$ & Low risk & $\begin{array}{l}\text { "Testing had been carried out at the } \mathrm{Na} \text { - } \\
\text { tional Institute of Nutrition to assure that } \\
\text { the placebo and vitamin A water miscible } \\
\text { solution were similar in taste, viscosity and } \\
\text { colour." }\end{array}$ \\
\hline
\end{tabular}

\begin{tabular}{l|l}
\hline Blinding? & Low risk \\
Blinding of provider &
\end{tabular}

Blinding of provider

"Personnel at the National Institute of $\mathrm{Nu}$ trition carried out the preparation of the supplements to assure that field personnel and the principal investigator were unaware of treatment regimen." 
Long 2007 (Continued)

\begin{tabular}{|c|c|c|}
\hline $\begin{array}{l}\text { Blinding? } \\
\text { Blinding of outcome assessor }\end{array}$ & Low risk & $\begin{array}{l}\text { "Personnel at the National Institute of } \mathrm{Nu} \text { - } \\
\text { trition carried out the preparation of the } \\
\text { supplements to assure that field personnel } \\
\text { and the principal investigator were unaware } \\
\text { of treatment regimen." }\end{array}$ \\
\hline Incomplete outcome data addressed? & Low risk & $\begin{array}{l}\text { Unclear what was done with data for } 7 \text { miss- } \\
\text { ing children, but dropout was small and sim- } \\
\text { ilar between groups ( } 4 \text { intervention, } 3 \text { con- } \\
\text { trol) }\end{array}$ \\
\hline Free of selective reporting? & Unclear risk & $\begin{array}{l}\text { Protocol not referenced, though the grant } \\
\text { applications may be available }\end{array}$ \\
\hline Free of other bias? & Low risk & This study appears to be free of other bias. \\
\hline
\end{tabular}

Pant 1996

Methods

Participants

Outcomes

Notes
Interventions

Cluster randomised trial in rural Nepal, Asia.

Children aged between 6 months and 10 years were eligible to participate in the study From 100 potentially eligible cluster sites, 75 were randomised (approximately 25,301 children). Baseline data on the number in each treatment group, proportion of male participants and mean age were not provided

The intervention groups were:

1. Vitamin A given as a single dose via a capsule (100,000 IU for children aged 6 to 12 months and 200,000 IU for children aged 1 to 10 years)

2. Control (not adequately described)

3. Nutritional education

Study duration: 24 months.

All- cause mortality and Bitot's spots.

No details on loss to follow- up were given. Inclusion/exclusion criteria were inadequately described. No nominators/denominators were available for Bitot's spots

\section{Risk of bias}

\begin{tabular}{lll} 
Bias & Authors' judgement & Support for judgement \\
\hline Adequate sequence generation? & Low risk & $\begin{array}{l}\text { "Using random number tables and the ref- } \\
\text { erence number for each block ...” }\end{array}$ \\
\hline Allocation concealment? & Unclear risk & $\begin{array}{l}\text { Insufficient detail provided to make judg- } \\
\text { ment. }\end{array}$
\end{tabular}

Vitamin A supplementation for preventing morbidity and mortality in children from 6 months to 5 years of age (Review) 
Pant 1996 (Continued)

\begin{tabular}{|c|c|c|}
\hline $\begin{array}{l}\text { Blinding? } \\
\text { Blinding of Participants }\end{array}$ & Unclear risk & $\begin{array}{l}\text { Insufficient detail provided to make judg- } \\
\text { ment. }\end{array}$ \\
\hline $\begin{array}{l}\text { Blinding? } \\
\text { Blinding of provider }\end{array}$ & Unclear risk & $\begin{array}{l}\text { Insufficient detail provided to make judg- } \\
\text { ment. }\end{array}$ \\
\hline $\begin{array}{l}\text { Blinding? } \\
\text { Blinding of outcome assessor }\end{array}$ & Unclear risk & $\begin{array}{l}\text { Insufficient detail provided to make judg- } \\
\text { ment. }\end{array}$ \\
\hline Incomplete outcome data addressed? & High risk & $\begin{array}{l}\text { No information regarding incomplete out- } \\
\text { come data addressed given }\end{array}$ \\
\hline Free of selective reporting? & High risk & $\begin{array}{l}\text { Very specific outcomes reported. Five types } \\
\text { of examinations were administered to the } \\
\text { study children: ophthalmic, physical, an- } \\
\text { thropometric, blood, and faecal; while data } \\
\text { in results is given only for prevalence of } \\
\text { Bitot's spots and all-cause mortality }\end{array}$ \\
\hline Free of other bias? & Unclear risk & $\begin{array}{l}\text { Insufficient detail provided to make judg- } \\
\text { ment. }\end{array}$ \\
\hline
\end{tabular}

\section{Pinnock 1986}

\begin{tabular}{|c|c|c|}
\hline Methods & \multicolumn{2}{|c|}{ Individually randomised study in urban area of Australia. } \\
\hline Participants & \multicolumn{2}{|c|}{$\begin{array}{l}\text { Children aged between } 1 \text { and } 4 \text { years of age in three general practices from Adelaide. } \\
\text { Children with more than } 15 \text { days of cough or three separate episodes of respiratory illness } \\
\text { during the preceding } 3 \text { months were eligible } \\
147 \text { children were randomised to the treatment groups. Mean age was } 39.3 \text { months. } 50 \% \\
\text { of the sample was male }\end{array}$} \\
\hline Interventions & \multicolumn{2}{|c|}{$\begin{array}{l}\text { Vitamin A administered orally as retinyl palmitate }(1160 \mathrm{mcg}) \text { three times per week for } 20 \\
\text { weeks versus placebo }\end{array}$} \\
\hline Outcomes & \multicolumn{2}{|c|}{ Acute respiratory infections, pneumonia, mean serum vitamin A } \\
\hline \multicolumn{3}{|l|}{ Notes } \\
\hline \multicolumn{3}{|l|}{ Risk of bias } \\
\hline Bias & Authors' judgement & Support for judgement \\
\hline Adequate sequence generation? & Low risk & $\begin{array}{l}\text { "Randomization of treatment was achieved } \\
\text { by combining active and placebo bottles in a } \\
\text { sequence, which was determined by consult- } \\
\text { ing a table of random numbers, and num- }\end{array}$ \\
\hline
\end{tabular}


Pinnock 1986 (Continued)

bering the bottles accordingly."

Probably done.

\begin{tabular}{|c|c|c|}
\hline Allocation concealment? & Unclear risk & $\begin{array}{l}\text { Insufficent information to permit judg- } \\
\text { ment. }\end{array}$ \\
\hline $\begin{array}{l}\text { Blinding? } \\
\text { Blinding of Participants }\end{array}$ & Low risk & $\begin{array}{l}\text { "The placebo was a similarly constituted } \\
\text { syrup omitting retinyl palmitate and la- } \\
\text { belled and bottled identically." }\end{array}$ \\
\hline $\begin{array}{l}\text { Blinding? } \\
\text { Blinding of provider }\end{array}$ & Low risk & $\begin{array}{l}\text { "All staff connected with the study remained } \\
\text { blind to the identity of the child's medica- } \\
\text { tion." }\end{array}$ \\
\hline $\begin{array}{l}\text { Blinding? } \\
\text { Blinding of outcome assessor }\end{array}$ & Low risk & $\begin{array}{l}\text { "All staff connected with the study remained } \\
\text { blind to the identity of the child's medica- } \\
\text { tion." }\end{array}$ \\
\hline Incomplete outcome data addressed? & Low risk & $\begin{array}{l}\text { A high rate of attrition, but reasons for with- } \\
\text { drawal given and that there were no signif- } \\
\text { icant changes in the distribution of major } \\
\text { potential confounding factors between the } \\
\text { two groups }\end{array}$ \\
\hline Free of selective reporting? & Unclear risk & The protocol of the study not available. \\
\hline Free of other bias? & Low risk & No other apparent bias was observed. \\
\hline
\end{tabular}

Pinnock 1988

Methods

Participants
Individually randomised study in urban area of Australia.

Children aged between 0 and 2 years with previous history of bronchiolitis and nasal culture positive for HSV were included

Children taking vitamin A, and those with cystic fibrosis, cardiopulmonary difficulties, major brain dysfunctions were excluded

206 children were randomised to the treatment groups. Mean age was 58 months. $60 \%$ sample was male

Interventions

Vitamin A administered as retinyl palmitate 4.2mg per week for 12 months versus placebo

Outcomes

Diarrhoea, diarrhoea-related hospitalisation, acute respiratory infections, pneumonia, pneumonia-related hospitalisation, mean serum vitamin A

Notes

Risk of bias 
Pinnock 1988 (Continued)

\begin{tabular}{|c|c|c|}
\hline Bias & Authors' judgement & Support for judgement \\
\hline Adequate sequence generation? & Low risk & $\begin{array}{l}\text { "Randomization was achieved by randomly } \\
\text { allocating four of eight batch numbers to } \\
\text { Vitamin A supplement and the remaining } \\
\text { four to placebo. The batch number code was } \\
\text { retained by the manufacturer." }\end{array}$ \\
\hline Allocation concealment? & Low risk & $\begin{array}{l}\text { "The batch number code was retained by } \\
\text { the manufacturer. The bottles were then } \\
\text { distributed sequentially according to batch } \\
\text { number as children presented..." } \\
\text { Probably done. }\end{array}$ \\
\hline $\begin{array}{l}\text { Blinding? } \\
\text { Blinding of Participants }\end{array}$ & Low risk & $\begin{array}{l}\text { "The placebo had an identical appearance } \\
\text { and formulation except for the active ingre- } \\
\text { dient." } \\
\text { Probably done. }\end{array}$ \\
\hline $\begin{array}{l}\text { Blinding? } \\
\text { Blinding of provider }\end{array}$ & Low risk & $\begin{array}{l}\text { "Both investigators and parents were blind } \\
\text { as to the treatment status of the child." }\end{array}$ \\
\hline $\begin{array}{l}\text { Blinding? } \\
\text { Blinding of outcome assessor }\end{array}$ & Low risk & $\begin{array}{l}\text { "Both investigators and parents were blind } \\
\text { as to the treatment status of the child ... } \\
\text { The batch number code was retained by the } \\
\text { manufacturer." }\end{array}$ \\
\hline Incomplete outcome data addressed? & Low risk & $\begin{array}{l}\text { Complete details of those excluded and lost } \\
\text { to follow-up were provided }\end{array}$ \\
\hline Free of selective reporting? & High risk & $\begin{array}{l}\text { Outcomes mentioned in methods not re- } \\
\text { ported in results. }\end{array}$ \\
\hline Free of other bias? & Low risk & This study appears to be free of other bias. \\
\hline
\end{tabular}

Rahman 2001

Methods

Participants
Individually randomised study conducted in an urban area of Bangladesh, Asia

Children aged between 12 and 35 months were eligible for inclusion in the study Children who had received Vitamin A within the previous 4 months, had severe malnutrition, with signs or symptoms of vitamin A or zinc deficiency, or with any systemic illness such as diarrhoea, respiratory infection, fever, or any other illness that warranted medical intervention at the time of enrolment were excluded 800 children were enrolled (200 in each of the four treatment groups). Mean age of participants was between 23.5 and 24.2 months across the treatment groups. $56 \%$ of the participants were male 
Rahman 2001 (Continued)

\begin{tabular}{ll}
\hline Interventions & There were four treatment groups: \\
1. Vitamin A 200,000 IU (60 mg) given as a single capsule at day 14, with placebo syrup \\
daily for 14 days \\
2. Placebo capsule at day 14 and placebo syrup for 14 days. \\
3. Vitamin A $200,000 \mathrm{IU}(60 \mathrm{mg})$ given as a single capsule at day 14 , with zinc syrup daily \\
for 14 days \\
4. Zinc syrup daily for 14 days, placebo capsule at day 14. \\
Duration of study: 6 months. \\
\hline
\end{tabular}

Outcomes

Diarrhoea, acute respiratory infections, serum vitamin A levels and vitamin deficiency

Notes

Data on treatment analysis was not presented. We have written to authors for data on each treatment arm

\section{Risk of bias}

Bias

Adequate sequence generation?

Low risk

\section{Support for judgement}

"The children were randomly assigned by a person not involved in the study who used permuted blocks of random numbers." Probably done.

"Sets of 2 bottles and 1 capsule for each child were serially numbered ... A local pharmaceutical company prepared the study syrups (zinc and placebo) which were supplied in identical 50-mL bottles ... The vitamin A and placebo capsules looked identical."

Probably done.

Blinding? Low risk

Blinding of Participants

Low risk

Blinding?

Blinding of provider

Blinding?

Blinding of outcome assessor
"The zinc and placebo syrups were supplied in bottles that looked identical, and the appearance and consistency of the syrups were similar. Vitamin A and placebo capsules were identical in appearance."

Probably done.

Identical presentation and: 'The randomisation code was kept sealed until the completion of the study.'

Probably done.

"The treatment allocations were disclosed after the final analysis." 
Rahman 2001 (Continued)

\begin{tabular}{l|l|l}
\hline Incomplete outcome data addressed? & Low risk & $\begin{array}{l}\text { Data on lost to follow-up given and also } \\
\text { stated that the baseline characteristics of } \\
\text { children who were excluded or lost to fol- } \\
\text { low-up were comparable to those of the chil- } \\
\text { dren who continued in the study }\end{array}$ \\
\hline $\begin{array}{l}\text { Free of selective reporting? } \\
\text { Free of other bias? }\end{array}$ & Unclear risk & Protocol not available. \\
\hline
\end{tabular}

Rahmathullah 1990

\begin{tabular}{ll}
\hline Methods & $\begin{array}{l}\text { Cluster-randomised trial conducted in Trichy district of Tamil Nadu in southern India, } \\
\text { Asia }\end{array}$ \\
\hline Participants & $\begin{array}{l}\text { Children aged } 6 \text { to } 60 \text { months were included in the study. } \\
\text { Clustering unit was "panchyat" (local-government areas). A total of } 206 \text { clusters were } \\
\text { formed, and the majority of them consisted of } 50 \text { to } 100 \text { children. The included clusters } \\
\text { had a total of } 15,419 \text { children of whom } 7764 \text { were in vitamin A group and } 7655 \text { in placebo } \\
\text { group }\end{array}$ \\
\hline
\end{tabular}

Interventions

Children in experimental group received weekly doses of 8333 IU vitamin A and $20 \mathrm{mg}$ vitamin E. The control group received $20 \mathrm{IU}$ of vitamin $\mathrm{E}$ only in peanut oil. Any children diagnosed with xerophthalmia at baseline, midterm, or final examination was given a highdose (200 000 IU) supplement of vitamin A and continued in the study. Supplementations were given for 52 weeks. Children who missed 7 consecutive dosages were excluded from the analysis

Outcomes

All-cause mortality, cause specific mortality of diarrhoea, measles and respiratory disease. Incidence of diarrhoea and respiratory disease morbidity

Notes

The baseline characteristics of the two groups were similar in terms of age and sex, onemonth history of diarrhoea and respiratory disease, anthropometric indexes of nutritional status, xerophthalmia status, five-year retrospective history of mortality of children under five, household economic, household hygienic status, and serum retinol levels. On average $>90 \%$ of the children were contacted each week, and the lowest coverage in any single week was $88 \% .11 \%$ had clinical evidence of xerophthalmia while about $38 \%$ had serum retinol concentrations $<0.35 \mathrm{mmol} / \mathrm{L}$ at baseline

\section{Risk of bias}

\begin{tabular}{|c|c|c|}
\hline Bias & Authors' judgement & Support for judgement \\
\hline Adequate sequence generation? & Unclear risk & $\begin{array}{l}\text { "The clusters were arranged according to } \\
\text { population size; after a random start, they } \\
\text { were assigned alternately to the treated or } \\
\text { control groups." } \\
\text { Exact method of sequence generation was }\end{array}$ \\
\hline
\end{tabular}

Vitamin A supplementation for preventing morbidity and mortality in children from 6 months to 5 years of age (Review) 
Rahmathullah 1990 (Continued)

not provided.

\begin{tabular}{|c|c|c|}
\hline Allocation concealment? & Low risk & $\begin{array}{l}\text { "...no one associated with the study was } \\
\text { aware of the colour code, which was held } \\
\text { by the Hoffmann-LaRoche until the study } \\
\text { ended." }\end{array}$ \\
\hline $\begin{array}{l}\text { Blinding? } \\
\text { Blinding of Participants }\end{array}$ & Low risk & $\begin{array}{l}\text { "The appearance and taste of the solutions } \\
\text { were identical ... no one associated with the } \\
\text { study was aware of the colour code, which } \\
\text { was held by the Hoffmann-LaRoche until } \\
\text { the study ended." } \\
\text { Probably done. }\end{array}$ \\
\hline $\begin{array}{l}\text { Blinding? } \\
\text { Blinding of provider }\end{array}$ & Low risk & $\begin{array}{l}\text { "The appearance and taste of the solutions } \\
\text { were identical ... no one associated with the } \\
\text { study was aware of the colour code, which } \\
\text { was held by the Hoffmann-LaRoche until } \\
\text { the study ended ... masked controlled..." } \\
\text { Probably done. }\end{array}$ \\
\hline
\end{tabular}

\begin{tabular}{l|l} 
Blinding? & Low risk \\
Blinding of outcome assessor &
\end{tabular}

"The appearance and taste of the solutions were identical ... no one associated with the study was aware of the colour code, which was held by the Hoffmann-LaRoche until the study ended ... masked controlled..."

Incomplete outcome data addressed? Low risk

"There was no difference in rates of contact between the treated and control groups. The reasons for lack of contact included moving from the study area ..."

Reasons for lost to follow-up given with a note that there was no difference in contact rates between the two groups

Free of selective reporting? Low risk

All important outcomes given in results as mentioned in the methods section

Free of other bias?

Low risk

No other apparent bias was noticed.

Ramakrishnan 1995

Methods

Participants
Individually randomised trial conducted in rural India, Asia

Children aged 6-36 months were eligible for inclusion in the trial. Those with ophthalmic signs of xerophthalmia, serious diseases, or severe malnutrition $(<60 \%$ of weight-for-age or $<85 \%$ of height-for-age of the National Center for Health Statistics median) were excluded and received appropriate treatment including vitamin A 
Ramakrishnan 1995 (Continued)

A total of 538 children were included, 309 in vitamin A group and 274 in placebo group. Mean age of children was 18.6 months and proportion males was $49.9 \%$

Interventions

Children in experimental group received vitamin A in a dose of 100,000 IU for children aged $<1$ year and 200,000 IU for children aged $>1$ year. The comparison group received only placebo. The interventions were given every 4 months for 12 months

Outcomes

Incidence of diarrhoea and respiratory disease.

Notes

Definition used for respiratory disease was too generalised to be included under lower respiratory tract infection. It mainly covered upper respiratory tract infections

Risk of bias

\begin{tabular}{ll|l}
\hline Bias & Authors' judgement & Support for judgement \\
\hline Adequate sequence generation? & Unclear risk & $\begin{array}{l}\text { "The study design was a randomised, dou- } \\
\text { ble-blind, placebo controlled intervention } \\
\text { trial in which every } 4 \text { mo the treatment } \\
\text { group received a high-dose vitamin A sup- } \\
\text { plement and the control group received a } \\
\text { placebo." } \\
\text { Insufficient detail provided. }\end{array}$ \\
\hline Allocation concealment? & Unclear risk & $\begin{array}{l}\text { Insufficent information to permit judg- } \\
\text { ment. }\end{array}$ \\
\hline
\end{tabular}

Blinding? Low risk

Blinding of Participants

Low risk

"The study design was a randomised, double-blind, placebo controlled intervention trial in which every 4 mo the treatment group received a high-dose vitamin A supplement and the control group received a placebo."

Statement that blinding occurred, no further details provided

\begin{tabular}{l|l}
\hline Blinding? & Low risk \\
Blinding of provider &
\end{tabular}

"The study design was a randomised, double-blind, placebo controlled intervention trial in which every 4 mo the treatment group received a high-dose vitamin A supplement and the control group received a placebo."

Statement that blinding occurred, no further details provided

Blinding?

Blinding of outcome assessor
Low risk
"The study design was a randomised, double-blind, placebo controlled intervention trial in which every 4 mo the treatment group received a high-dose vitamin A sup- 
Ramakrishnan 1995 (Continued)

plement and the control group received a placebo."

Statement that blinding occurred, no further details provided

Incomplete outcome data addressed? Low risk

"Out of the 660 children who were eligible, a final group of 592 children who had both pre- and post-anthropometric measurements were used in this analysis. The losses at follow-up due to migration $(\mathrm{n}=50)$ , death $(\mathrm{n}=10)$ and incomplete measurements $(n=8)$ were similar for both groups.

Losses were not large and balanced between groups; unlikely to introduce substantial bias here. Clinically relevant impact unlikely

"The examination for ophthalmic signs of vitamin A deficiency, using WHO criteria (27), was conducted by trained ophthalmologists from the Department of Ophthalmology, $\mathrm{CMCH}$, at baseline and at the end of the 1-y follow-up period. Blood samples were also taken (from finger pricks) at the beginning and the end of the study by using 250-pt capillary tubes. Serum retinol concentrations were estimated by using reversed-phase HPLC at the Wellcome Research Laboratory, $\mathrm{CMCH}$, Vellore, using retinyl acetate and all trans-retinol (Sigma Chemical Co, St Louis) as standards.”

Though measured, serum retinol results are never reported.

Ranjini 2001

Methods

Participants
Individually randomised trial conducted in India, Asia.

Children aged 12-60 months and having recurrent respiratory tract infections were eligible for inclusion in the trial. Those with mild or moderate asthma; children who were on vitamin supplements or who had received a massive dose of vitamin A in the previous 6 months, those with pre-existing congenital heart disease, chronic lung disease, pulmonary tuberculosis or immunodeficiency disorders, those on immunosuppressive drugs and those with clinically apparent vitamin A deficiency were excluded

A total of 61 children were randomised in which 30 were in vitamin A group and 31 in placebo group. The mean age of children was 35.7 months and proportion of males was 
Ranjini 2001 (Continued)

$60.7 \%$

\begin{tabular}{ll} 
Interventions & $\begin{array}{l}\text { Children in experimental group received a single dose of vitamin A in a dose of } 200 \text { 000 } \\
\text { IU. The comparison group was given placebo in archis oil. Follow- up period was } 6 \text { months }\end{array}$ \\
\hline Outcomes & Incidence of respiratory disease. Mean vitamin A serum levels \\
\hline Notes & Definition of respiratory illness used was not specific enough \\
\hline
\end{tabular}

Risk of bias

\begin{tabular}{|c|c|c|}
\hline Bias & Authors' judgement & Support for judgement \\
\hline Adequate sequence generation? & Unclear risk & $\begin{array}{l}\text { "Eligible children were randomly allocated } \\
\text { to receive either } 200,000 \text { IU of vitamin A in } \\
\text { arachis oil or a placebo containing arachis } \\
\text { oil without vitamin A." } \\
\text { Details of sequence generation not specified. }\end{array}$ \\
\hline Allocation concealment? & Unclear risk & $\begin{array}{l}\text { Insufficent information to permit judg- } \\
\text { ment. }\end{array}$ \\
\hline
\end{tabular}

\begin{tabular}{|c|c|c|}
\hline $\begin{array}{l}\text { Blinding? } \\
\text { Blinding of Participants }\end{array}$ & Unclear risk & $\begin{array}{l}\text { "Eligible children were randomly allocated } \\
\text { to receive either } 200,000 \text { IU of vitamin A in } \\
\text { arachis oil or a placebo containing arachis } \\
\text { oil without vitamin A." }\end{array}$ \\
\hline
\end{tabular}

\begin{tabular}{l|l} 
Blinding? & Unclear risk
\end{tabular}

Blinding of provider

\begin{tabular}{l|l|l}
$\begin{array}{l}\text { Blinding? } \\
\text { Blinding of outcome assessor }\end{array}$ & Unclear risk & Not mentioned. \\
\hline
\end{tabular}

Incomplete outcome data addressed? Unclear risk

"Of the 61 included children, seven (three in the placebo group and four in vitamin A group) did not return for follow-up." (second page)

Authors do not address the reasons for losses to follow- up, and given the small size of this trial, bias may or may not be introduced depending on why the losses occurred by group. given this lack of discussion, it is difficult to judge weather or not there is a low or high risk of bias, but it is likely to be high

Free of selective reporting? Unclear risk

"Details of doctor or outpatient visits and hospital cough, wheezy breathing, shortness of breath and fever. Details of doctor or outpatient visits and hospital admissions during

Vitamin A supplementation for preventing morbidity and mortality in children from 6 months to 5 years of age (Review) 
the study period were also recorded. During each monthly follow-up visit, the entries in the monthly calendar were reviewed with the parent." (1st, 2nd page)

Hospitalisation was not reported though it was collected.

Reddy 1986

\begin{tabular}{ll}
\hline Methods & Factorial design individually randomised trial conducted in India, Asia \\
\hline Participants & $\begin{array}{l}\text { Children aged } 1-5 \text { years were included in the study. Those without parental consent were } \\
\text { excluded } \\
\text { A total of } 487 \text { children were randomised to four intervention groups. Mean age and } \\
\text { proportion of males were not described }\end{array}$ \\
\hline Interventions & $\begin{array}{l}\text { The four intervention groups were as follows: } \\
\text { Group A: oral administration of L-tetramisole }(50 \mathrm{mg}) \text { followed } 3 \text { days later by a dose of } \\
200000 \text { IU of vitamin A. } \\
\text { Group B: massive dose of vitamin A of } 200000 \mathrm{IU} \\
\text { Group C L-tetramisole (50 mg) orally. } \\
\text { Group D placebo. }\end{array}$ \\
\hline Outcomes & Mean vitamin A serum levels. \\
\hline Notes & Data have been included in two sets. \\
\hline
\end{tabular}

\section{Risk of bias}

\begin{tabular}{|c|c|c|}
\hline Bias & Authors' judgement & Support for judgement \\
\hline Adequate sequence generation? & Unclear risk & $\begin{array}{l}\text { "After the baseline survey, the children } \\
\text { were assigned, randomly, into four groups, } \\
\text { matched for age, anthropometry, serum vi- } \\
\text { tamin A, and worm infestation and the fol- } \\
\text { lowing treatment was given." } \\
\text { Insufficient details provided to make judge- } \\
\text { ment. }\end{array}$ \\
\hline Allocation concealment? & Unclear risk & $\begin{array}{l}\text { Insufficent information to permit judg- } \\
\text { ment. }\end{array}$ \\
\hline $\begin{array}{l}\text { Blinding? } \\
\text { Blinding of Participants }\end{array}$ & Unclear risk & Insufficent information to permit judgment \\
\hline
\end{tabular}


Reddy 1986 (Continued)

\begin{tabular}{|c|c|c|}
\hline $\begin{array}{l}\text { Blinding? } \\
\text { Blinding of provider }\end{array}$ & Unclear risk & Insufficent information to permit judgment \\
\hline $\begin{array}{l}\text { Blinding? } \\
\text { Blinding of outcome assessor }\end{array}$ & Unclear risk & Insufficent information to permit judgment \\
\hline Incomplete outcome data addressed? & Unclear risk & Insufficent information to permit judgment \\
\hline Free of selective reporting? & Unclear risk & $\begin{array}{l}\text { "After } 6 \text { months and } 12 \text { months, heights } \\
\text { and weights were measured, clinical status } \\
\text { was assessed and morbidity for the preced- } \\
\text { ing one month was recorded. Finger-prick } \\
\text { blood samples were collected and serum vi- } \\
\text { tamin A levels were estimated, stool samples } \\
\text { were examined for the presence of ascaris } \\
\text { ova and other parasites." } \\
\text { Authors do not report height or weights, or } \\
\text { detailed data on clinical status or morbidity }\end{array}$ \\
\hline Free of other bias? & Unclear risk & $\begin{array}{l}\text { Insufficent information to permit judg- } \\
\text { ment. }\end{array}$ \\
\hline
\end{tabular}

Reddy 1986 (2)

Methods

Participants

Interventions

Outcomes

Notes As Reddy 1986 above.

Ross 1993 HEALTH

Methods $\quad$ Randomised double-blind controlled trial conducted in guinea savannah area of Ghana, Africa

Participants Children aged 6 to 59 months were included. Those with active xerophthalmia or measles were excluded from the trial the moment them were confirmed

A total of 1455 children were included. The proportion of male children was $49.5 \%$

Interventions

Children in vitamin A group received either 200,000 IU retinol equivalent for participants aged $>12$ months or 100,000 IU for aged 6-12 months. The control group received placebo. Interventions were given every 4 months for 12 months

Vitamin A supplementation for preventing morbidity and mortality in children from 6 months to 5 years of age (Review) 


\section{Ross 1993 HEALTH (Continued)}

Outcomes

Notes
All-cause mortality. Mean daily prevalence of respiratory tract disease, diarrhoea, measles, malaria. Mean vitamin A serum levels, all-cause hospitalisations

The study populations were rural and their main staple foods are deficient in carotenoids and vitamin A. Vitamin A deficiency and xerophthalmia were recognised as problems locally. Children were visited weekly for 1 year. Children in the Health Study were followed up 596 child-years for vitamin A group and 589 for control group. According to WHO, Ghana is a country with a high child mortality rate (i.e. $>40 / 1000)$

\section{Risk of bias}

\begin{tabular}{|c|c|c|}
\hline Bias & Authors' judgement & Support for judgement \\
\hline Adequate sequence generation? & Unclear risk & $\begin{array}{l}\text { "Randomisation was blocked in both stud- } \\
\text { ies to ensure similar numbers of children in } \\
\text { each group in each part of the study area." } \\
\text { Explicit methods for generating allocation } \\
\text { sequence not available }\end{array}$ \\
\hline
\end{tabular}

\begin{tabular}{|c|c|c|}
\hline Allocation concealment? & Low risk & $\begin{array}{l}\text { "Randomisation was carried out in London } \\
\text { by an independent statistician, who held the } \\
\text { randomisation code and who also did an in- } \\
\text { terim analysis of the mortality results from } \\
\text { the Survival Study for the trial's data-moni- } \\
\text { toring committee after a year of follow-up." } \\
\text { Code was protected for the duration of the } \\
\text { trial. }\end{array}$ \\
\hline $\begin{array}{l}\text { Blinding? } \\
\text { Blinding of Participants }\end{array}$ & Low risk & $\begin{array}{l}\text { "Vitamin A and placebo were supplied by } \\
\text { Hoffmann-La-Roche's Sight and Life Pro- } \\
\text { gramme, and were similar in taste and } \\
\text { colour. In the Survival Study, liquid vitamin } \\
\text { A or placebo was supplied in opaque } 150 \\
\mathrm{~mL} \text { bottles containing } 20 \mathrm{IU} / \mathrm{mL} \text { vitamin } \\
\mathrm{E} \text { alone (placebo) or plus } 100000 \mathrm{IU} / \mathrm{mL} \\
\text { retinol equivalent as retinyl palmitate (vita- } \\
\text { min A) in purified peanut oil. Each bottle } \\
\text { had a unique number, and was labelled with } \\
\text { a cluster code before despatch to Ghana." }\end{array}$ \\
\hline $\begin{array}{l}\text { Blinding? } \\
\text { Blinding of provider }\end{array}$ & Low risk & As above; probably done. \\
\hline $\begin{array}{l}\text { Blinding? } \\
\text { Blinding of outcome assessor }\end{array}$ & Low risk & $\begin{array}{l}\text { In view of the blinding procedures in place } \\
\text { elsewhere in the study this was probably ad- } \\
\text { equate }\end{array}$ \\
\hline
\end{tabular}




\section{Ross 1993 HEALTH (Continued)}

\begin{tabular}{|c|c|c|}
\hline Incomplete outcome data addressed? & Unclear risk & $\begin{array}{l}\text { Morbidity information was missing for } 5 \text { - } \\
7 \% \text { of the weekly follow-up visits owing to } \\
\text { temporary absences of the study children } \\
\text { or their mothers, but the missing data were } \\
\text { equally distributed between the treatment } \\
\text { groups }\end{array}$ \\
\hline Free of selective reporting? & High risk & $\begin{array}{l}\text { There was an indication that xerophthalmia } \\
\text { data were measured, but none are reported. } \\
\text { No protocol is available }\end{array}$ \\
\hline Free of other bias? & Low risk & No other apparent bias was noted. \\
\hline
\end{tabular}

Ross 1993 SURVIVAL

\begin{tabular}{|c|c|c|}
\hline Methods & \multicolumn{2}{|c|}{ Cluster randomised trial conducted Ghana, Africa. } \\
\hline Participants & \multicolumn{2}{|c|}{$\begin{array}{l}\text { Children aged 6-90 months were eligible for inclusion in the trial. Xeropthalmic children } \\
\text { were excluded } \\
\text { Study involved } 185 \text { cluster that included } 21906 \text { children. Proprtion of male children was } \\
51.5 \%\end{array}$} \\
\hline Interventions & \multicolumn{2}{|c|}{$\begin{array}{l}\text { The experimental group received vitamin A supplementation in a dose of } 100000 \mathrm{IU} \text { for } \\
\text { children aged } 6-11 \text { months and } 200,000 \mathrm{IU} \text { for older children. The comparison group } \\
\text { received placebo. Vitamin } \mathrm{E} \text { in a dose of } 20 \mathrm{IU} \text { was given to both the groups. Intervention } \\
\text { were delivered every } 4 \text { months for } 24 \text { months }\end{array}$} \\
\hline Outcomes & \multicolumn{2}{|c|}{$\begin{array}{l}\text { All-cause mortality and cause specific mortality of diarrhoea, respiratory disease, measles } \\
\text { and meningitis. Mean vitamin A serum levels. Malaria prevalence }\end{array}$} \\
\hline \multicolumn{3}{|l|}{ Notes } \\
\hline \multicolumn{3}{|l|}{ Risk of bias } \\
\hline Bias & Authors' judgement & Support for judgement \\
\hline Adequate sequence generation? & Unclear risk & $\begin{array}{l}\text { "Randomisation was blocked in both stud- } \\
\text { ies to ensure similar numbers of children in } \\
\text { each group in each part of the study area." } \\
\text { Explicit methods for generating allocation } \\
\text { sequence not available }\end{array}$ \\
\hline Allocation concealment? & Low risk & $\begin{array}{l}\text { "Randomisation was carried out in London } \\
\text { by an independent statistician, who held the } \\
\text { randomisation code and who also did an in- } \\
\text { terim analysis of the mortality results from } \\
\text { the Survival Study for the trial's data-moni- } \\
\text { toring committee after a year of follow-up." }\end{array}$ \\
\hline
\end{tabular}


Ross 1993 SURVIVAL (Continued)

Code was protected for the duration of the trial.

\begin{tabular}{|c|c|c|}
\hline $\begin{array}{l}\text { Blinding? } \\
\text { Blinding of Participants }\end{array}$ & Low risk & $\begin{array}{l}\text { "Vitamin A and placebo were supplied by } \\
\text { Hoffmann-La-Roche's Sight and Life Pro- } \\
\text { gramme, and were similar in taste and } \\
\text { colour. In the Survival Study, liquid vitamin } \\
\text { A or placebo was supplied in opaque } 150 \\
\mathrm{~mL} \text { bottles containing } 20 \mathrm{IU} / \mathrm{mL} \text { vitamin } \\
\text { E alone (placebo) or plus } 100000 \mathrm{IU} / \mathrm{mL} \\
\text { retinol equivalent as retinyl palmitate (vita- } \\
\text { min A) in purified peanut oil. Each bottle } \\
\text { had a unique number, and was labelled with } \\
\text { a cluster code before despatch to Ghana." } \\
\text { Probably done. }\end{array}$ \\
\hline $\begin{array}{l}\text { Blinding? } \\
\text { Blinding of provider }\end{array}$ & Low risk & As above; probably done. \\
\hline $\begin{array}{l}\text { Blinding? } \\
\text { Blinding of outcome assessor }\end{array}$ & Low risk & $\begin{array}{l}\text { In view of the blinding procedures in place } \\
\text { elsewhere in the study this was probably ad- } \\
\text { equate }\end{array}$ \\
\hline Incomplete outcome data addressed? & Unclear risk & $\begin{array}{l}8.4 \% \text { (1847) children lost to follow-up and } \\
\text { similar between treatment groups } \\
\text { The reasons for losses to follow-up are not } \\
\text { provided. }\end{array}$ \\
\hline
\end{tabular}

Free of selective reporting? High risk

Authors collected data on night blindness, Bitot's spots, and xerophthalmia but do not report it

Free of other bias?

Unclear risk

The method for inflating the CIs is not welldescribed. No ICC reported

Semba 1992

Methods Individually randomised trial conducted in Indonesia, Asia.

Participants

Children aged 3-6 years were eligible for inclusion in the study. Those who had median weight for age $<80 \%$ of the National Center for Health Statistics were excluded from the study. Children with serious illness were also excluded from the study and treated appropriately

A total of 236 children were randomised to four intervention groups. Mean age of participants was 58.9 months and proportion of males was $71.6 \%$

Vitamin A supplementation for preventing morbidity and mortality in children from 6 months to 5 years of age (Review) 
Semba 1992 (Continued)

\begin{tabular}{ll}
\hline Interventions & $\begin{array}{l}\text { There were } 4 \text { intervention groups. Two groups (vitamin A and placebo) had clinical signs } \\
\text { of vitamin A deficiency while two groups were clinically normal } \\
\text { Participants in vitamin A groups received a single dose of } 60000 \text { microgram of retinol } \\
\text { equivalent. Children were followed for one month }\end{array}$ \\
\hline Outcomes & Mean vitamin A serum levels. \\
\hline Notes & The 2 vitamin A and 2 placebo groups were combined, respectively, for meta- analysis \\
\hline
\end{tabular}

Risk of bias

\begin{tabular}{|c|c|c|}
\hline Bias & Authors' judgement & Support for judgement \\
\hline Adequate sequence generation? & Unclear risk & $\begin{array}{l}\text { "A double-masked, randomised, placebo- } \\
\text { controlled, clinical trial involving } 236 \\
\text { preschool children, age } 3-6 \text { years, was car- } \\
\text { ried out at the outpatient clinic of the Ci- } \\
\text { cendo Eye Hospital in Bandung, West Java, } \\
\text { Indonesia." } \\
\text { Details of sequence generation not pro- } \\
\text { vided. }\end{array}$ \\
\hline
\end{tabular}

\begin{tabular}{|c|c|c|}
\hline Allocation concealment? & Low risk & $\begin{array}{l}\text { "The treatment code was broken after the } \\
\text { conclusion of the study." } \\
\text { Allocation sequence appears to have been } \\
\text { protected. }\end{array}$ \\
\hline
\end{tabular}

Blinding? Low risk

Blinding of Participants

\begin{tabular}{l|l} 
& \\
& \\
\hline $\begin{array}{l}\text { Blinding? } \\
\text { Blinding of provider }\end{array}$ & Low risk \\
\hline $\begin{array}{l}\text { Blinding? } \\
\text { Blinding of outcome assessor }\end{array}$ & Unclear risk \\
\hline
\end{tabular}

"A double-masked, randomised, placebocontrolled, clinical trial involving 236 preschool children."

"The vitamin A and placebo solutions were supplied in coded containers, and the identity of the solutions was known only to the manufacturer... The solutions were identical in colour, taste, smell and consistency."

As above; providers likely to have been adequately blinded.

The provider administering vitamin $\mathrm{A}$ and the outcome assessor appear to be different individuals and it is not clearly stated if the outcome assessors were also blinded to group assignment

232/236 children enrolled at baseline completed the study protocol. (page 102)

Incomplete outcome data addressed? Low risk 
Semba 1992 (Continued)

\begin{tabular}{|c|c|c|}
\hline Free of selective reporting? & Unclear risk & $\begin{array}{l}\text { Does not reference a protocol or trial regis- } \\
\text { tration and does not state that all measured } \\
\text { outcomes are reported }\end{array}$ \\
\hline Free of other bias? & Unclear risk & $\begin{array}{l}\text { Insufficient information to permit judg- } \\
\text { ment. }\end{array}$ \\
\hline
\end{tabular}

Semba 1995

\begin{tabular}{ll} 
Methods & Individually randomised study in rural Indonesia, Asia. \\
\hline Participants & $\begin{array}{l}\text { Children aged } 6 \text { months at vaccination against measles were included } \\
\text { Children who had measles previously were excluded. } \\
336 \text { children were randomised to the two treatment groups. Baseline details on age and } \\
\text { gender were not provided }\end{array}$ \\
\hline Interventions & $\begin{array}{l}\text { Vitamin A given as a single dose (100,000 IU) versus placebo } \\
\text { Vitamin A or placebo given with measles vaccine. } \\
\text { Study duration: } 6 \text { months. }\end{array}$ \\
\hline Outcomes & Measles. \\
\hline Notes & $\begin{array}{l}\text { The primary objective of the study was to measure the antibody response to measles } \\
\text { vaccine when given along with vitamin A or placebo. Trialists found a significant decrease } \\
\text { in seroconversion of measles vaccine in the intervention group compared to placebo }\end{array}$ \\
\hline
\end{tabular}

\section{Risk of bias}

\begin{tabular}{|c|c|c|}
\hline Bias & Authors' judgement & Support for judgement \\
\hline Adequate sequence generation? & Low risk & $\begin{array}{l}\text { "Treatment was assigned by random num- } \\
\text { ber table in blocks of ten." } \\
\text { Probably done. }\end{array}$ \\
\hline Allocation concealment? & Low risk & $\begin{array}{l}\text { "Infants received identification numbers as } \\
\text { they were enrolled in the study, and each } \\
\text { identification number had an envelope with } \\
\text { an identical capsule containing either vita- } \\
\text { min A or placebo." } \\
\text { Probably done. }\end{array}$ \\
\hline $\begin{array}{l}\text { Blinding? } \\
\text { Blinding of Participants }\end{array}$ & Low risk & $\begin{array}{l}\text { "Vitamin A, } 100000 \mathrm{IU} \text {, or placebo in iden- } \\
\text { tical capsules." } \\
\text { Probably done. }\end{array}$ \\
\hline $\begin{array}{l}\text { Blinding? } \\
\text { Blinding of provider }\end{array}$ & Low risk & $\begin{array}{l}\text { "Infants received identification numbers as } \\
\text { they were enrolled in the study, and each }\end{array}$ \\
\hline
\end{tabular}

Vitamin A supplementation for preventing morbidity and mortality in children from 6 months to 5 years of age (Review) 
Semba 1995 (Continued)

\begin{tabular}{|c|c|c|}
\hline & & $\begin{array}{l}\text { identification number had an envelope with } \\
\text { an identical capsule containing either vita- } \\
\text { min A or placebo." } \\
\text { Probably done. }\end{array}$ \\
\hline $\begin{array}{l}\text { Blinding? } \\
\text { Blinding of outcome assessor }\end{array}$ & Low risk & As above; probably done. \\
\hline Incomplete outcome data addressed? & High risk & $\begin{array}{l}\text { "Follow-up rates were } 93 \% \text { and } 90 \% \text { at one } \\
\text { and six months post immunisation, respec- } \\
\text { tively." } \\
\text { The reasons for lost to follow-up not given; } \\
\text { only available case data given }\end{array}$ \\
\hline Free of selective reporting? & Unclear risk & Study protocol was not available. \\
\hline Free of other bias? & Unclear risk & $\begin{array}{l}\text { Inadequate information presented to assess } \\
\text { this formally. }\end{array}$ \\
\hline
\end{tabular}

Sempertegui 1999

Methods

Participants

Interventions

Notes

\section{Risk of bias}

Indivdualy randomised trial conducted in the northwestern region of the Quito, Ecuador, South America

Children aged 6 to 36 months were eligible for inclusion in the review. Those children who had clinical vitamin A deficiency, who did not reliably stayed at home or at day care centres during weekdays or who had been given multivitamins in the last 3 months, were excluded

A total of 400 children were randomised either to vitamin A or placebo group with equal (200 each) in both the groups. Mean age of participants was 21.1 months and half of the study population was male

Children in the supplement-treated group received a weekly dose of 10,000 IU of vitamin A for 40 weeks, and children in the non-supplement group received a weekly placebo for the same period

Incidence of diarrhoea and respiratory disease morbidity. Mean vitamin A serum levels

The baseline study characteristics were comparable in both the groups. Study was conducted in a slum with substantial rates of malnutrition and subclinical vitamin A deficiency. Morbidity surveillance was done weekly

\section{Bias}

\section{Authors' judgement}

\section{Support for judgement}


Sempertegui 1999 (Continued)

\begin{tabular}{|c|c|c|}
\hline Adequate sequence generation? & Low risk & $\begin{array}{l}\text { "For random allocation of each child to } \\
\text { treatment or placebo group the following } \\
\text { procedure was performed. Identical flasks } \\
\text { containing vitamin A or placebo were num- } \\
\text { bered from } 1 \text { to } 400 \text { by members of the } \\
\text { study team in Boston, Massachusetts. The } \\
\text { local Ethical Committee of the Ecuado- } \\
\text { rian Biotechnology Corporation in Quito } \\
\text { did not know the identity of the active or } \\
\text { placebo flasks, because they did not have the } \\
\text { code. Then, this committee assigned each } \\
\text { flask to a specific child from a random list by } \\
\text { using a table of random numbers. After ran- } \\
\text { domisation, the ethical committee received } \\
\text { the confidential code from Boston." }\end{array}$ \\
\hline Allocation concealment? & Low risk & $\begin{array}{l}\text { "After randomisation, the ethical committee } \\
\text { received the confidential code from Boston } \\
\text { and kept it for the remainder of the study, } \\
\text { when it was revealed." }\end{array}$ \\
\hline $\begin{array}{l}\text { Blinding? } \\
\text { Blinding of Participants }\end{array}$ & Low risk & $\begin{array}{l}\text { "Identical flasks containing vitamin A or } \\
\text { placebo were numbered from } 1 \text { to } 400 \text { by } \\
\text { members of the study team in Boston, Mas- } \\
\text { sachusetts." } \\
\text { Trial described as double blind; given pro- } \\
\text { cedures used for ensuring that intervention } \\
\text { and placebo were identical, it is very likely } \\
\text { that blinding of children was maintained }\end{array}$ \\
\hline $\begin{array}{l}\text { Blinding? } \\
\text { Blinding of provider }\end{array}$ & Low risk & $\begin{array}{l}\text { "The syrups were administered at home and } \\
\text { at day care centres by study researchers who } \\
\text { were blinded to the presence or absence of } \\
\text { active drug." }\end{array}$ \\
\hline $\begin{array}{l}\text { Blinding? } \\
\text { Blinding of outcome assessor }\end{array}$ & Low risk & $\begin{array}{l}\text { Outcome assessors were the same as the } \\
\text { providers, therefore blinded }\end{array}$ \\
\hline Incomplete outcome data addressed? & Low risk & $\begin{array}{l}\text { "A total of } 306 \text { children finished the study, } \\
\text { because } 50 \text { children from the supplement- } \\
\text { treated group and } 44 \text { from the non- supple- } \\
\text { mented group were lost to follow-up when } \\
\text { their families moved to other neighbour- } \\
\text { hoods. Of all children, } 70 \% \text {, including those } \\
\text { lost to follow-up, accumulated }>30 \text { weeks } \\
\text { of observation... Children with incomplete } \\
\text { follow-up were distributed evenly in relation } \\
\text { to the baseline variables (Table } 2 \text { )." } \\
\text { Loss to follow-up similar in magnitude in }\end{array}$ \\
\hline
\end{tabular}

Vitamin A supplementation for preventing morbidity and mortality in children from 6 months to 5 years of age (Review) 


\begin{tabular}{|c|c|c|}
\hline Free of selective reporting? & Unclear risk & $\begin{array}{l}\text { Protocol referred to but not referenced. Not } \\
\text { explicitly stated if all measured outcomes } \\
\text { were reported }\end{array}$ \\
\hline Free of other bias? & Low risk & No other apparent bias was noted \\
\hline
\end{tabular}

\section{Shankar 1999}

\begin{tabular}{ll}
\hline Methods & This study was an individually randomised trial conducted in Guinea Bissau, Africa \\
\hline Participants & $\begin{array}{l}\text { Children aged 6-60 months and those who plan to reside within the study area for at } \\
\text { least } 1 \text { year were eligible for inclusion in the trial. Those with ocular signs of vitamin A } \\
\text { deficiency or history of night blindness were excluded } \\
\text { A total of } 480 \text { children were randomised either to vitamin A or placebo group. The vitamin } \\
\text { A group had } 239 \text { participants whole placebo group 241. Proportion of males in the study } \\
\text { population was } 51 \%\end{array}$ \\
\hline
\end{tabular}

Interventions

The experimental group received vitamin A supplementation in a dose of $100000 \mathrm{IU}$ for children aged $<1$ year and 200,000 IU for older children. The comparison group received placebo. Both the groups received 20 IU of vitamin E. Intervention was given every 4 months for 13 months

Outcomes

Incidence of diarrhoea and malaria morbidity. Mean vitamin A serum levels

Notes

Risk of bias

\begin{tabular}{|c|c|c|}
\hline Bias & Authors' judgement & Support for judgement \\
\hline Adequate sequence generation? & Low risk & $\begin{array}{l}\text { "Within these strata, children were indi- } \\
\text { vidually allocated vitamin A or placebo in } \\
\text { blocks of four (two vitamin A, two placebo) } \\
\text { by computer generated randomly permu- } \\
\text { tated codes." }\end{array}$ \\
\hline Allocation concealment? & Low risk & $\begin{array}{l}\text { "Capsules were encoded into four groups; } \\
\text { two placebo and two vitamin A, and the } \\
\text { code was kept offsite by personnel who were } \\
\text { not involved in the study." }\end{array}$ \\
\hline $\begin{array}{l}\text { Blinding? } \\
\text { Blinding of Participants }\end{array}$ & Low risk & $\begin{array}{l}\text { Identical capsules, and allocation was con- } \\
\text { cealed and code kept off site. Described as } \\
\text { double-blind }\end{array}$ \\
\hline
\end{tabular}


Shankar 1999 (Continued)

\begin{tabular}{|c|c|c|}
\hline $\begin{array}{l}\text { Blinding? } \\
\text { Blinding of provider }\end{array}$ & Low risk & As above; probably done. \\
\hline $\begin{array}{l}\text { Blinding? } \\
\text { Blinding of outcome assessor }\end{array}$ & Low risk & $\begin{array}{l}\text { Unlikely that the trained village-based mor- } \\
\text { bidity worker knew the assignments, how- } \\
\text { ever this is never stated explicitly } \\
\text { Probably done. }\end{array}$ \\
\hline Incomplete outcome data addressed? & Low risk & $\begin{array}{l}\text { "Cross sectional follow-up rates for mid- } \\
\text { study and end of study were } 428 \text { of } \\
480(89 \%) \text { and } 410 \text { of } 480(85 \%) \text {, re- } \\
\text { spectively, and similar for vitamin A and } \\
\text { placebo groups. During the trial two chil- } \\
\text { dren dropped out, } 66 \text { moved out of the } \\
\text { study area, and two died." } \\
\text { Intention-to-treat used. Missing outcome } \\
\text { data balanced in numbers across groups }\end{array}$ \\
\hline Free of selective reporting? & Unclear risk & $\begin{array}{l}\text { Protocol not referenced and not stated that } \\
\text { all measured outcomes were reported. Data } \\
\text { at } 7 \text { months not completely reported }\end{array}$ \\
\hline Free of other bias? & Low risk & No other apparent bias was noted. \\
\hline
\end{tabular}

Sinha 1976

\begin{tabular}{|c|c|c|}
\hline Methods & \multicolumn{2}{|c|}{ Individually randomised trial conducted in India, Asia. } \\
\hline Participants & \multicolumn{2}{|c|}{$\begin{array}{l}\text { Children aged } 2 \text { months to } 4.5 \text { years were eligible for inclusion in the trial. No exclusion } \\
\text { criteria was described } \\
\text { A total of } 306 \text { children were randomised either to vitamin A or placebo group in equal } \\
\text { numbers ( } 153 \text { in each group) }\end{array}$} \\
\hline Interventions & \multicolumn{2}{|c|}{$\begin{array}{l}\text { Children in experimental group received vitamin A in a dose of } 200000 \mathrm{IU} \text { every } 4 \text { months } \\
\text { for } 12 \text { months. The comparison group received placebo only }\end{array}$} \\
\hline Outcomes & \multicolumn{2}{|c|}{ Bitot spots. Side effects; vomiting. } \\
\hline Notes & \multicolumn{2}{|c|}{ The people in the study population were extremely poor. } \\
\hline \multicolumn{3}{|l|}{ Risk of bias } \\
\hline Bias & Authors' judgement & Support for judgement \\
\hline Adequate sequence generation? & Unclear risk & $\begin{array}{l}\text { "The children were divided in two groups } \\
\text { of } 153 \text { each (two of the children died in the } \\
\text { 1st year and two left the village) and were }\end{array}$ \\
\hline
\end{tabular}

Vitamin A supplementation for preventing morbidity and mortality in children from 6 months to 5 years of age (Review) 


\begin{tabular}{|c|c|c|}
\hline & & $\begin{array}{l}\text { matched for age, sex, socioeconomic status, } \\
\text { and playmate contacts. One of the children } \\
\text { of each matched pair was selected randomly } \\
\text { for receiving vitamin A and the other child } \\
\text { received a placebo." } \\
\text { No detail about randomisation method pro- } \\
\text { vided. }\end{array}$ \\
\hline Allocation concealment? & Unclear risk & $\begin{array}{l}\text { "In a separate laboratory, the designated 2- } \\
\text { ml dose of vitamin A or placebo for each } \\
\text { child was put into a vial labelled with the } \\
\text { child's number and the vials were then } \\
\text { shipped to the field station for distribution. } \\
\text { Neither the clinician nor the paramedical } \\
\text { workers, who personally fed vitamin A and } \\
\text { placebo or examined the children for the } \\
\text { signs and symptoms of vitamin A deficiency, } \\
\text { knew which children received vitamin A." } \\
\text { Insufficient details provided. }\end{array}$ \\
\hline $\begin{array}{l}\text { Blinding? } \\
\text { Blinding of Participants }\end{array}$ & Low risk & $\begin{array}{l}\text { "Neither the clinician nor the paramedical } \\
\text { workers, who personally fed vitamin A and } \\
\text { placebo or examined the children for the } \\
\text { signs and symptoms of vitamin A deficiency, } \\
\text { knew which children received vitamin A." } \\
\text { Probably done. }\end{array}$ \\
\hline $\begin{array}{l}\text { Blinding? } \\
\text { Blinding of provider }\end{array}$ & Low risk & $\begin{array}{l}\text { "Neither the clinician nor the paramedi- } \\
\text { cal workers, who personally fed vitamin A } \\
\text { and placebo or examined the children for } \\
\text { the signs and symptoms of vitamin A de- } \\
\text { ficiency, knew which children received vi- } \\
\text { tamin A." "The placebo consisted of de- } \\
\text { odorized arachis oil which was coloured and } \\
\text { favoured with orange to match exactly the } \\
\text { vitamin A preparation." } \\
\text { Provider blinded. }\end{array}$ \\
\hline
\end{tabular}

Blinding? Low risk

Blinding of outcome assessor

"Neither the clinician nor the paramedical workers, who personally fed vitamin A and placebo or examined the children for the signs and symptoms of vitamin A deficiency, knew which children received vitamin A."

Incomplete outcome data addressed? Unclear risk

Based on the outcome data reported it does not seem that any children dropped out (i. e., there were no losses); however, this could be because the authors are conducting an intent-to-treat analysis but never say so. They 
Sinha 1976 (Continued)

\begin{tabular}{|l|l} 
are not explicit in this regard, as such the \\
risk of bias due to incomplete outcome data \\
is unclear
\end{tabular}

Free of selective reporting? Unclear risk

Does not reference a protocol or trial registration and does not state that all measured outcomes are reported

Free of other bias?

Low risk

No other apparent bias was noted.

Smith 1999

Methods

Factorial design, individually randomised trial conducted in Belize, Central America

Participants

Children aged 2.2 to 5.5 years were eligible for inclusion in the trial. Those with fever or serious respiratory illness were excluded

A total of 51 children were randomised to four intervention groups. Mean age of children were 46.3 months

Interventions

The four intervention groups were as follow:

Vitamin A only; received 10000 IU vitamin A

Zinc only; received $70 \mathrm{mg}$ zinc

Vitamin A + Zinc; received vitamin A and zinc in above mentioned dosage

Placebo

Duration of study was for 6 months.

\begin{tabular}{l|l}
\hline Outcomes & Vitamin A serum level. \\
\hline Notes & \\
\hline
\end{tabular}

Risk of bias

\begin{tabular}{ll|l}
\hline Bias & Authors' judgement & Support for judgement \\
\hline Adequate sequence generation? & Unclear risk & $\begin{array}{l}\text { "The children selected were randomly as- } \\
\text { signed to receive one of the following sup- } \\
\text { plements once per week: placebo; Zn, } 70 \\
\text { mg as Zn gluconate; vitamin A, 3030 RE as } \\
\text { retinyl palmitate; or a combination of vita- } \\
\text { min A and Zn." } \\
\text { Stated to be randomised, but no further data } \\
\text { reported. }\end{array}$ \\
\hline Allocation concealment? & Unclear risk & Unclear risk \\
\hline $\begin{array}{l}\text { Blinding? } \\
\text { Blinding of Participants }\end{array}$ & & Insufficient details provided. \\
\hline
\end{tabular}

Vitamin A supplementation for preventing morbidity and mortality in children from 6 months to 5 years of age (Review)

Copyright $\Subset 201$ I The Cochrane Collaboration. Published by John Wiley \& Sons, Ltd. 
Smith 1999 (Continued)

10625) prepared as a beverage dissolved in approximately $120 \mathrm{~mL}$ of water."

Stated to be "double-blind" in the article keywords, but there appear to be no details about blinding methods in the text. The intervention (or no intervention in the placebo group) were diluted in the same solution, so presumably all groups were identical

\begin{tabular}{l|l|l}
\hline $\begin{array}{l}\text { Blinding? } \\
\text { Blinding of provider }\end{array}$ & Unclear risk & Not adequately reported. \\
\hline $\begin{array}{l}\text { Blinding? } \\
\text { Blinding of outcome assessor }\end{array}$ & Unclear risk & Not adequately reported. \\
\hline Incomplete outcome data addressed? & Unclear risk & $\begin{array}{l}\text { Insufficient details provided; losses not ac- } \\
\text { counted for by group and small sample size } \\
\text { makes this especially relevant }\end{array}$ \\
\hline
\end{tabular}

Free of selective reporting? Unclear risk

Does not reference a protocol or trial registration and does not state that all measured outcomes are reported

Sommer 1986

Methods

Participants
Cluster randomised trial conducted in a rural area of Indonesia, Asia

Children aged between 0 and 5 years were included. Children with active xerophthalmia were excluded from the study

29,236 children from 450 villages (cluster sites) in Java. 50\% of the sample were male
Vitamin A (capsules administered twice over the course of the study: 200,000 IU of Vitamin A) was compared with a no treatment control group that served as a waiting list control

$40 \mathrm{IU}$ of vitamin $\mathrm{E}$ was also administered with vitamin A.

Duration of study: 9-13 months.
Outcomes

Mortality, diarrhoea, Bitot's spots, night blindness, xerophthalmia

Notes

ICC not reported (confidence intervals from analyses reported to have been adjusted for design effect). TJL back-calculated an ICC of 0.008307 from effect estimate provided in paper

Vitamin A was not intended to have been distributed to children under the age of 12 months, but it would appear that some 0 to 12 month old children received the vitamin A capsule. Outcome data were reported on a cohort of 0 to 12 month old children 
Sommer 1986 (Continued)

Risk of bias

\begin{tabular}{|c|c|c|}
\hline Bias & Authors' judgement & Support for judgement \\
\hline Adequate sequence generation? & Unclear risk & $\begin{array}{l}\text { "From a random start, } 450 \text { villages were sys- } \\
\text { tematically selected for the study; these were } \\
\text { then randomised for capsule distribution af- } \\
\text { ter the baseline examination..." } \\
\text { Inadequate information provided. }\end{array}$ \\
\hline Allocation concealment? & Unclear risk & $\begin{array}{l}\text { Inadequate information was presented in or- } \\
\text { der to assess this item in relation to timing } \\
\text { of recruitment into the study }\end{array}$ \\
\hline $\begin{array}{l}\text { Blinding? } \\
\text { Blinding of Participants }\end{array}$ & Unclear risk & $\begin{array}{l}\text { "The Government of Indonesia would not } \\
\text { condone the use of placebos but field-work- } \\
\text { ers collecting demographic data were un- } \\
\text { aware that mortality was a research issue." } \\
\text { Described as a controlled study, without ad- } \\
\text { equate description of what control group re- } \\
\text { ceived }\end{array}$ \\
\hline $\begin{array}{l}\text { Blinding? } \\
\text { Blinding of provider }\end{array}$ & Unclear risk & $\begin{array}{l}\text { "The Government of Indonesia would not } \\
\text { condone the use of placebos but field-work- } \\
\text { ers collecting demographic data were un- } \\
\text { aware that mortality was a research issue." } \\
\text { Described as a controlled study, without ad- } \\
\text { equate description of what control group re- } \\
\text { ceived }\end{array}$ \\
\hline
\end{tabular}

Blinding?

Blinding of outcome assessor
Unclear risk
"The Government of Indonesia would not condone the use of placebos but field-workers collecting demographic data were unaware that mortality was a research issue." Described as a controlled study, without adequate description of what control group received

"Follow-up information was available on $89 \%$ of the programme children and $88.4 \%$ of the controls."

Authors indicate percent remaining per group at follow- up, but nothing more detailed

Trial protocol not available. 
Sommer 1986 (Continued)

\begin{tabular}{|c|c|c|}
\hline Free of other bias? & Unclear risk & $\begin{array}{l}\text { Insufficent information to permit judge- } \\
\text { ment. }\end{array}$ \\
\hline
\end{tabular}

\section{Stabell 1995}

Methods

Participants

Interventions

Notes

\section{Risk of bias}

\begin{tabular}{|c|c|c|}
\hline Bias & Authors' judgement & Support for judgement \\
\hline Adequate sequence generation? & Unclear risk & $\begin{array}{l}\text { "Carrying out a double-blinded, ran- } \\
\text { domised, placebo-controlled trial." } \\
\text { Sequence generation not mentioned in the } \\
\text { paper. }\end{array}$ \\
\hline
\end{tabular}

\begin{tabular}{|c|c|c|}
\hline Allocation concealment? & Unclear risk & $\begin{array}{l}\text { Nothing mentioned regarding allocation } \\
\text { concealment. }\end{array}$ \\
\hline $\begin{array}{l}\text { Blinding? } \\
\text { Blinding of Participants }\end{array}$ & Unclear risk & $\begin{array}{l}\text { Claimed it was blinded but no detail pro- } \\
\text { vided. }\end{array}$ \\
\hline $\begin{array}{l}\text { Blinding? } \\
\text { Blinding of provider }\end{array}$ & Unclear risk & $\begin{array}{l}\text { Claimed it was blinded but no detail pro- } \\
\text { vided. }\end{array}$ \\
\hline
\end{tabular}

Blinding? Unclear risk

Blinding of outcome assessor

Incomplete outcome data addressed?

Unclear risk
Children aged 6 months of age years were eligible for inclusion in the trial

A total of 68 children were included in which 32 were in vitamin A group and 36 in placebo

Children in the intervention group received vitamin A in a dose of $100000 \mathrm{IU}$ at the time of measles vaccination at age of 6 and 9 months. The comparison group received placebo only

Side effects: Bulging fontanelle.

Denominator data not entirely clear in Table 1 of the study.

\begin{tabular}{|c|c|c|}
\hline 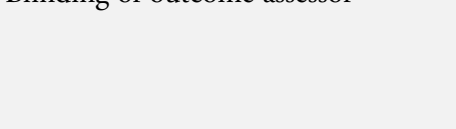 & & $\begin{array}{l}\text { or bulging } \\
\text { Appears outcome assessors were the same in- } \\
\text { dividuals as the investigators }\end{array}$ \\
\hline Incomplete outcome data addressed? & Unclear risk & $\begin{array}{l}\text { Losses to follow-up by group indicated but } \\
\text { no detail provided. Unclear what losses ac- } \\
\text { tually occurred in Table } 1\end{array}$ \\
\hline
\end{tabular}


Stabell 1995 (Continued)

\begin{tabular}{|c|c|c|}
\hline Free of selective reporting? & Unclear risk & $\begin{array}{l}\text { No protocol referenced, nor statement that } \\
\text { all measured outcomes were reported }\end{array}$ \\
\hline Free of other bias? & Unclear risk & $\begin{array}{l}\text { Short communication, insufficient detail to } \\
\text { make an informed judgment }\end{array}$ \\
\hline
\end{tabular}

Stansfield 1993

Methods

Participants

Interventions

Outcomes

Notes
This randomised, placebo-controlled was conducted north west of Haiti, Latin America

Children aged 6 to 83 months were included in the study. Those with corneal changes consistent with vitamin A deficiency, with measles and those had received vitamin A within the past 4 months were excluded

A total of 13651 children were found to be eligible for inclusion in the trial. The proportion of males in the study population was $49 \%$

The vitamin A group received 100,000 IU supplements every 4 months for 3 distribution cycle for those 6 to 11 months and 200,000 IU for the older, while the other group only received placebo

2 week prevalence of signs of respiratory tract infections: cold, cough and rapid breathing and diarrhoea

A slightly larger number of children (55\%) were assigned to vitamin A group. There was a significant difference between 2 study groups with respect to age. Study area had a high prevalence of malnutrition and xerophthalmia in the study population. Children were visited every 2 weeks for 12 months. The respiratory disease morbidity was reported with respect to cold, cough and rapid breathing which were too non- specific for inclusion under umbrella of pneumonia or lower respiratory tract infection morbidity in our review

\section{Risk of bias}

\begin{tabular}{lll}
\hline Bias & Authors' judgement & Support for judgement \\
\hline Adequate sequence generation? & High risk & $\begin{array}{l}\text { Quote from the author: "A random num- } \\
\text { ber generator was used to number the first } \\
\text { household and the households were num- } \\
\text { bered sequentially thereafter. Every other } \\
\text { household was given a green capsule, while } \\
\text { the rest were given red capsules." } \\
\text { Alternate allocation. }\end{array}$ \\
\hline Allocation concealment? & Low risk & $\begin{array}{l}\text { Quote from the author: "The manufacturer } \\
\text { (Roche) held the code until the study was } \\
\text { completed." }\end{array}$
\end{tabular}

Vitamin A supplementation for preventing morbidity and mortality in children from 6 months to 5 years of age (Review) 
Stansfield 1993 (Continued)

\begin{tabular}{|c|c|c|}
\hline $\begin{array}{l}\text { Blinding? } \\
\text { Blinding of Participants }\end{array}$ & Low risk & $\begin{array}{l}\text { "The colour code was held only by the man- } \\
\text { ufacturer until the study was completed." } \\
\text { Probably done. }\end{array}$ \\
\hline $\begin{array}{l}\text { Blinding? } \\
\text { Blinding of provider }\end{array}$ & Low risk & $\begin{array}{l}\text { "Before the study inquiries among health } \\
\text { workers and community members had indi- } \\
\text { cated no symbolism associated with or pref- } \\
\text { erence for either green or red." } \\
\text { Highly unlikely that providers would be bi- } \\
\text { ased about a single intervention }\end{array}$ \\
\hline $\begin{array}{l}\text { Blinding? } \\
\text { Blinding of outcome assessor }\end{array}$ & Low risk & $\begin{array}{l}\text { "The colour code was held only by the man- } \\
\text { ufacturer until the study was completed." } \\
\text { Probably done. }\end{array}$ \\
\hline Incomplete outcome data addressed? & Low risk & $\begin{array}{l}\text { "The frequency of non-participation was es- } \\
\text { sentially identical among children from even } \\
\text { and odd-numbered households." } \\
\text { Probably done. }\end{array}$ \\
\hline
\end{tabular}

Free of selective reporting? High risk

"We did not collect data on the impact of supplementation on vitamin A status, or on the incidence, duration, or severity of symptoms of infection."

Only mortality and morbidity outcomes given. Protocol not available

Free of other bias?

Low risk

This study appears to be free of other bias.

van Agtmaal 1988

Methods

Participants

Interventions

Outcomes

Notes

Risk of bias
Individually randomised, non-placebo trial conducted in Thailand, Asia

Participants had a mean age of 3.1 years. No exclusion criteria was described

Study included 30 children in which 14 were in vitamin A group and 21 in control group

Children in experimental group received a single dose vitamin A in a dose of 200000 IU.

Study participants were followed for 4 months

Mean vitamin A serum levels.

Children were recruited from three rural day care centres.

Bias

Authors' judgement

Support for judgement

Vitamin A supplementation for preventing morbidity and mortality in children from 6 months to 5 years of age (Review) 
van Agtmaal 1988 (Continued)

\begin{tabular}{|c|c|c|}
\hline Adequate sequence generation? & Unclear risk & $\begin{array}{l}\text { "After selection, } 14 \text { children were randomly } \\
\text { supplemented with a single, oral dose of } \\
\text { vitamin A ( } 110 \text { mg retinylpalmitate, } 200 \text {, } \\
000 \mathrm{IU}) \text {, according to WHO recommenda- } \\
\text { tions (9). and } 21 \text { children served as a control } \\
\text { group." } \\
\text { Inadequate information provided. }\end{array}$ \\
\hline Allocation concealment? & Unclear risk & Inadequate information provided. \\
\hline $\begin{array}{l}\text { Blinding? } \\
\text { Blinding of Participants }\end{array}$ & Unclear risk & Inadequate information provided. \\
\hline $\begin{array}{l}\text { Blinding? } \\
\text { Blinding of provider }\end{array}$ & Unclear risk & Inadequate information provided. \\
\hline $\begin{array}{l}\text { Blinding? } \\
\text { Blinding of outcome assessor }\end{array}$ & Unclear risk & Inadequate information provided. \\
\hline Incomplete outcome data addressed? & High risk & $\begin{array}{l}\text { "Due to the absence of some children at the } \\
\text { different time points the number of data } \\
\text { available for statistical analysis was less than } \\
\text { the total number of children involved in this } \\
\text { study ... the number of children from whom } \\
\text { complete data sets could be collected was } \\
\text { rather low." } \\
\text { No comprehensive data given on lost to fol- } \\
\text { low-up nor reasons for loss }\end{array}$ \\
\hline Free of selective reporting? & High risk & $\begin{array}{l}\text { Does not report data on serum retinol levels, } \\
\text { which were collected } / \text { measured }\end{array}$ \\
\hline Free of other bias? & Unclear risk & Inadequate information provided. \\
\hline
\end{tabular}

Venkatarao 1996

Methods

Participants
Individual randomised trial conducted in India, Asia.

Infants aged 6 months were included. Proportion of males in the study was 50\%

A total of 909 infants were randomised to three intervention groups

The three intervention groups were as follows:

Group AA: Mother received and infants both received vitamin A

Group AP: Mother received vitamin A while infant received placebo

Group PP: Both mother and infant received placebo.

Dose of vitamin A for infant was 200000 IU. 
Venkatarao 1996 (Continued)

Outcomes All-cause mortality and cause specific mortality of diarrhoea and respiratory disease. Incidence of diarrhoea and respiratory disease morbidity

Notes We have included the data for groups AA vs. AP.

\section{Risk of bias}

\begin{tabular}{|c|c|c|}
\hline Bias & Authors' judgement & Support for judgement \\
\hline Adequate sequence generation? & Unclear risk & $\begin{array}{l}\text { "Each pair of subjects enrolled for the study } \\
\text { was randomly allocated to one of the follow- } \\
\text { ing three groups: (i) AA-Both mother and } \\
\text { infant received Vitamin A, the former soon } \\
\text { after delivery and the latter at } 6 \text { months; } \\
\text { (ii) AP: Mother received Vitamin A but her } \\
\text { infant received a placebo (Sesame oil); and } \\
\text { (iii) PP: Both mother and infant received } \\
\text { placebo, the former Vitamin E and the lat- } \\
\text { ter Sesame oil." } \\
\text { Insufficient detail to form judgment. }\end{array}$ \\
\hline Allocation concealment? & Unclear risk & Insufficient detail to form judgment. \\
\hline $\begin{array}{l}\text { Blinding? } \\
\text { Blinding of Participants }\end{array}$ & Low risk & $\begin{array}{l}\text { "At the age of } 6 \text { to } 6 \mathrm{Vi} \text { months, the infant } \\
\text { was weighed again and given the appropri- } \\
\text { ate syrup by the Medical Officer from coded } \\
\text { bottles, supplied again by the Statistical Sec- } \\
\text { tion at the Camp Office." } \\
\text { Probably done. }\end{array}$ \\
\hline
\end{tabular}

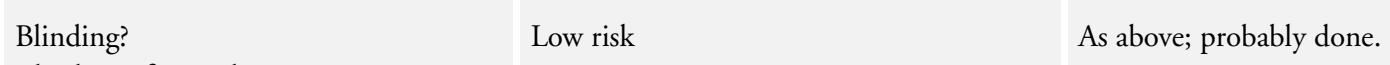

Blinding of provider

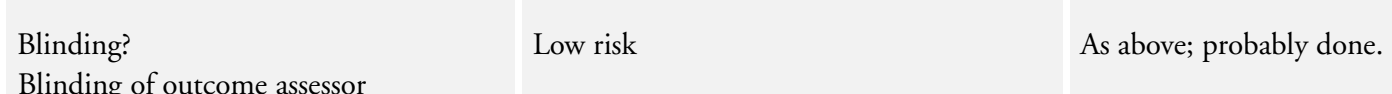

Blinding of outcome assessor

Incomplete outcome data addressed? Unclear risk

" 4 each in the AA and AP groups and 5 in the PP group were withdrawn from the trial on medical grounds such as congenital abnormalities, epileptic fits or jaundice. $\mathrm{Mi}$ gration accounted for the loss of 34 infants in the AA group, 25 in the AP group and 20 in the PP group while 7, 9 and 7 were excluded due to other miscellaneous reasons. Of the remaining 263, 255 and 256 infants in the three group, 233 in the AA and 228 each in the AP and PP groups were followedup very regularly and form the basis for anal- 
Venkatarao 1996 (Continued)

\begin{tabular}{|c|c|c|}
\hline & & $\begin{array}{l}\text { yses in this report." } \\
\text { They provided specific information about } \\
\text { losses by group. However, it is unclear why } \\
263,255 \text { and } 256 \text { infants that remain in the } \\
\text { three group after attrition is described results } \\
\text { in only } 233 \text { in the AA and } 228 \text { each in the } \\
\text { AP and PP groups being used as the basis } \\
\text { for analysis }\end{array}$ \\
\hline Free of selective reporting? & Low risk & $\begin{array}{l}\text { Does not reference a protocol or trial reg- } \\
\text { istration and do not state that all measured } \\
\text { outcomes are reported }\end{array}$ \\
\hline Free of other bias? & Low risk & $\begin{array}{l}\text { "Quality control of the morbidity data col- } \\
\text { lected by the field investigators was under- } \\
\text { taken throughout. As long recall periods } \\
\text { pose problems, the collection of morbidity } \\
\text { data was intensified from once a fortnight } \\
\text { to once a week when the study had been in } \\
\text { progress for } 9 \text { months." } \\
\text { Authors attempted to minimise other biases } \\
\text { such as recall bias, though specific details of } \\
\text { "quality control" are not provided }\end{array}$ \\
\hline
\end{tabular}

Vijayaraghavan 1990

Methods Cluster randomised study in rural India, Asia.

Participants

Children aged 1-5 years were eligible for entry in the study. Children with corneal involvement were excluded from the review

15,775 children in 84 clusters were randomised to the treatment groups. $50.4 \%$ participants were male

Interventions $\quad$ Vitamin A given twice (200,000 IU) versus placebo (archis oil)

Study duration: not clear.

Outcomes Mortality, diarrhoea, acute respiratory infections, measles.

Notes Respiratory infection has non-specific definition of "clinically significant cough"

Risk of bias

\begin{tabular}{ll|l} 
Bias & Authors' judgement & Support for judgement \\
\hline Adequate sequence generation? & Unclear risk & $\begin{array}{l}\text { "The villages were allocated randomly into } \\
\text { two groups-treatment and control." } \\
\text { Insufficient detail to form judgment. }\end{array}$
\end{tabular}

Vitamin A supplementation for preventing morbidity and mortality in children from 6 months to 5 years of age (Review) 
Vijayaraghavan 1990 (Continued)

\begin{tabular}{|c|c|c|}
\hline Allocation concealment? & Unclear risk & Insufficient detail provided. \\
\hline $\begin{array}{l}\text { Blinding? } \\
\text { Blinding of Participants }\end{array}$ & Low risk & $\begin{array}{l}\text { "The trial was double blind: the investi- } \\
\text { gators and medical officers did not know } \\
\text { which were the treatment and which were } \\
\text { the control areas. They were not aware } \\
\text { whether the dose they were distributing was } \\
\text { vitamin A or placebo. Decoding was done } \\
\text { only after data had been collected." }\end{array}$ \\
\hline $\begin{array}{l}\text { Blinding? } \\
\text { Blinding of provider }\end{array}$ & Low risk & As above; probably done. \\
\hline $\begin{array}{l}\text { Blinding? } \\
\text { Blinding of outcome assessor }\end{array}$ & Low risk & As above probably done. \\
\hline Incomplete outcome data addressed? & Unclear risk & Insufficient detail provided. \\
\hline Free of selective reporting? & High risk & $\begin{array}{l}\text { Incidence of infections outcome not given } \\
\text { with respect to vitamin A and control } \\
\text { groups. Given according to the clinical vita- } \\
\text { min A status of all the study children }\end{array}$ \\
\hline Free of other bias? & Low risk & This study appears to be free of other bias. \\
\hline
\end{tabular}

\section{West 1991}

\begin{tabular}{ll}
\hline Methods & Cluster randomised study in rural Nepal, Asia. \\
\hline Participants & $\begin{array}{l}\text { Children aged between } 0 \text { and } 5 \text { years were eligible for the study. Children with xeroph- } \\
\text { thalmia were included. Children who had recently participated in a Vitamin A programme } \\
\text { were excluded from the study } \\
28,630 \text { children in } 261 \text { clusters were recruited. } 51.3 \% \text { sample was male }\end{array}$ \\
\hline Interventions & $\begin{array}{l}\text { Vitamin A (100,000 IU for } 6-11 \text { months and } 200,000 \text { IU for children } 12 \text { months and } \\
\text { older) administered } 1 \text { to } 3 \text { times was compared with a very low dose of vitamin A (1000 } \\
\text { IU). Both supplements contained } 40 \text { IU vitamin E } \\
\text { Study duration:16 months. }\end{array}$ \\
\hline Outcomes & $\begin{array}{l}\text { Mortality, cause-specific mortality, Bitot's spots, night blindness, xerophthalmia } \\
\text { Notes }\end{array}$ \\
\hline $\begin{array}{l}\text { ICC not disclosed, although study estimates reported to have been adjusted for the unit } \\
\text { of allocation } \\
\text { Study had additional recruitment phases in second and third treatment cycles. } 1807 \text { and } \\
\text { 2018 children entered at } 4 \text { and } 8 \text { months }\end{array}$ \\
\hline
\end{tabular}

\section{Risk of bias}

Vitamin A supplementation for preventing morbidity and mortality in children from 6 months to 5 years of age (Review) 
West 1991 (Continued)

\begin{tabular}{|c|c|c|}
\hline Bias & Authors' judgement & Support for judgement \\
\hline Adequate sequence generation? & Unclear risk & $\begin{array}{l}\text { "After blocking on the local development } \\
\text { area, the } 261 \text { wards were randomly assigned } \\
\text { to receive vitamin A supplementation or } \\
\text { placebos at } 4 \text {-month intervals." } \\
\text { Inadequately described to permit judgment. }\end{array}$ \\
\hline Allocation concealment? & Unclear risk & $\begin{array}{l}\text { "Both the investigators and communities } \\
\text { were masked to the random assignment." } \\
\text { The study was a cluster-designed trial and } \\
\text { there was insufficient information to de- } \\
\text { termine whether allocation took place be- } \\
\text { fore or after treatment group assignment was } \\
\text { known }\end{array}$ \\
\hline
\end{tabular}

Blinding? $\quad$ Low risk

Blinding of Participants
"The supplements were given as single-dose gelatin capsules of identical taste and appearance."

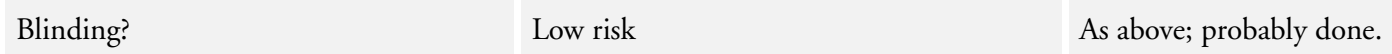

Blinding of provider

Blinding?
Blinding of outcome assessor Low risk

As above; probably done.

Incomplete outcome data addressed? Unclear risk

\begin{abstract}
"All analyses were carried out on an intention-to-treat basis. Computed mortality rates were based on child-years of observation."

“...all children living in wards which received high dose vitamin A every 4 months were considered to have been treated with vitamin $\mathrm{A}$, and all children living in wards which received placebo were considered 'untreated."”

The rates of withdrawal were balanced between the treatment groups and the data were analysed based on patient years of observation. The unclear reasons for withdrawals, variable duration of follow-up due to more than recruitment cycle and the low rate of mortality in relation to the withdrawal rates mean that it is uncertain whether the study is at risk of attrition bias
\end{abstract}


West 1991 (Continued)

\begin{tabular}{l|l|l}
\hline Free of selective reporting? & Low risk & $\begin{array}{l}\text { Complete data for all time points were avail- } \\
\text { able for the review. The last available obser- } \\
\text { vation reported in a follow-up article gave } \\
\text { a RR for mortality slightly higher than that } \\
\text { for the } 12 \text { month data given in the primary } \\
\text { study report }(0.74 \text { versus } 0.7)\end{array}$ \\
\hline Free of other bias? & Low risk & $\begin{array}{l}\text { A method for estimating the ICCs was re- } \\
\text { ported in Katz 1988 (Journal of interna- } \\
\text { tional epidemiology) }\end{array}$ \\
\hline
\end{tabular}

Characteristics of excluded studies [ordered by study ID]

\begin{tabular}{ll}
\hline Study & Reason for exclusion \\
\hline Bahl 1997 & The study included children currently having diarrhoea. \\
\hline Bhaskaram 1997 & The study was not a randomised controlled trial. \\
\hline Bloem 1990 & The study was not a randomised controlled trial. The mean age of children was 6.6 years (range 3-9 years) \\
\hline Kothari 1991 & The study was not a randomised controlled trial. \\
\hline Semba 1990 & Vitamin A was given as a therapeutic intervention for Bitot's spots \\
\hline Semba 2005 & The study population consisted of children infected with HIV \\
\hline Wu 2007 & The study was not a randomised controlled trial. \\
\hline Yang 2002 & $\begin{array}{l}\text { Other micronutrients were supplemented with vitamin A and these supplements were not balanced out in the } \\
\text { control group. It was difficult to disaggregate the effect of vitamin A }\end{array}$ \\
\hline
\end{tabular}

Characteristics of studies awaiting assessment [ordered by study ID]

\section{Aklamati 2006}

Methods Individually randomised, placebo-controlled trial conducted in Zambia, Africa

Participants Boys 3-4 years old were eligible for inclusion in the trial. A total of 36 children were included in the trial in which 19 were in vitamin $\mathrm{A}$ and 17 in placebo group

Interventions The intervention group received a single dose of $60 \mathrm{mg}$ vitamin $\mathrm{A}$ and control group received the same amount of placebo 


\section{Aklamati 2006 (Continued)}

Outcomes Mean plasma retinol levels, prevalence of fever, diarrhoea, rhinorrhoea, cough and malaria

Notes Data were available only in the form of abstract and the numbers do not match given in the results section of abstract. It was decided among the group to wait for publication of this study before we include it in the review

DEVTA trial 2007

Methods Cluster-randomised trial conducted in Northern India, Asia.

Participants Children aged 1-6 years were eligible for inclusion in the review. Total clusters were 72 in which 36 clusters received vitamin A supplementation while 36 acted as control. Authors claim to include a total of 1 million children in the trial

Interventions Children in experimental group received 200,000 IU of vitamin A every 6-months for 5 years. Vitamin A was supplemented on mass treatment days by village child care workers

Outcomes All-cause mortality, cause specific mortality of diarrhoea, pneumonia, measles and malnutrition. Mean vitamin A serum levels, incidence of Bitot's spots and prevalence of measles and pneumonia morbidity

Notes This is the largest randomised controlled trial conducted on vitamin A but has not been published yet. The current data is based on the abstract presented in ILSI Micronutrient Forum, Istanbul, 16-18 April 2007. It does not contain detail information on conduct of trial neither it give details on attrition of the study. We contacted all the authors of the trial multiple times and asked for more details on methods and results but did not receive any positive response. As we did not have sufficient information on methods and outcome we decided to wait for publication of results of this large trial. We aim to include that in the next update of this review 
DATA ANDANALYSES

Comparison 1. Vitamin A versus Control

\begin{tabular}{|c|c|c|c|c|}
\hline Outcome or subgroup title & $\begin{array}{l}\text { No. of } \\
\text { studies }\end{array}$ & $\begin{array}{c}\text { No. of } \\
\text { participants }\end{array}$ & Statistical method & Effect size \\
\hline $\begin{array}{l}1 \text { Mortality (all-cause) at Longest } \\
\text { Follow-up }\end{array}$ & 17 & & Risk Ratio (Fixed, 95\% CI) & $0.76[0.69,0.83]$ \\
\hline $\begin{array}{l}2 \text { Mortality (all-cause) at Longest } \\
\text { Follow-up (by Age) }\end{array}$ & 5 & & Risk Ratio (Fixed, 95\% CI) & Subtotals only \\
\hline 2.16 to 12 months old & 4 & & Risk Ratio (Fixed, 95\% CI) & $0.59[0.43,0.82]$ \\
\hline 2.21 to 5 years old & 4 & & Risk Ratio (Fixed, 95\% CI) & $0.68[0.57,0.81]$ \\
\hline $\begin{array}{l}3 \text { Mortality (all-cause) at Longest } \\
\text { Follow-up (by Sex) }\end{array}$ & 5 & & Risk Ratio (Fixed, 95\% CI) & Subtotals only \\
\hline 3.1 Males & 5 & & Risk Ratio (Fixed, 95\% CI) & $0.80[0.66,0.97]$ \\
\hline 3.2 Females & 5 & & Risk Ratio (Fixed, 95\% CI) & $0.79[0.65,0.95]$ \\
\hline $\begin{array}{l}4 \text { Mortality (all-cause) at Longest } \\
\text { Follow-up (Sensitivity Analysis } \\
\text { including DEVTA trial) }\end{array}$ & 18 & & Risk Ratio (Fixed, 95\% CI) & $0.88[0.84,0.94]$ \\
\hline $\begin{array}{l}5 \text { Mortality due to Diarrhoea at } \\
\text { Longest Follow-up }\end{array}$ & 7 & & Risk Ratio (Fixed, 95\% CI) & $0.72[0.57,0.91]$ \\
\hline $\begin{array}{l}6 \text { Mortality due to Measles at } \\
\text { Longest Follow-up }\end{array}$ & 5 & & Risk Ratio (Fixed, 95\% CI) & $0.80[0.51,1.24]$ \\
\hline $\begin{array}{l}7 \text { Mortality due to Meningitis at } \\
\text { Longest Follow-up }\end{array}$ & 3 & & Risk Ratio (Fixed, 95\% CI) & $0.57[0.17,1.88]$ \\
\hline $\begin{array}{l}8 \text { Mortality due to LRTI at } \\
\text { Longest Follow-up }\end{array}$ & 7 & & Risk Ratio (Fixed, 95\% CI) & $0.78[0.54,1.14]$ \\
\hline $\begin{array}{l}9 \text { Diarrhoea Incidence at Longest } \\
\text { Follow-up }\end{array}$ & 13 & & Risk Ratio (Fixed, 95\% CI) & $0.85[0.82,0.87]$ \\
\hline $\begin{array}{l}10 \text { Diarrhoea Prevalence at } \\
\text { Longest Follow-up }\end{array}$ & 3 & & Risk Ratio (Fixed, 95\% CI) & $1.08[1.05,1.12]$ \\
\hline $\begin{array}{l}11 \text { Measles Incidence at Longest } \\
\text { Follow-up }\end{array}$ & 6 & & Risk Ratio (Fixed, 95\% CI) & $0.50[0.37,0.67]$ \\
\hline $\begin{array}{l}12 \text { Malaria Incidence at Longest } \\
\text { Follow-up }\end{array}$ & 1 & 174132 & Risk Ratio (M-H, Fixed, 95\% CI) & $0.73[0.60,0.88]$ \\
\hline $\begin{array}{l}13 \text { Malaria Prevalence at Longest } \\
\text { Follow-up }\end{array}$ & 2 & & Risk Ratio (Fixed, 95\% CI) & $0.73[0.41,1.28]$ \\
\hline $\begin{array}{l}14 \text { Lower Respiratory Tract } \\
\text { Infection Incidence at Longest } \\
\text { Follow-up }\end{array}$ & 9 & & Risk Ratio (Fixed, 95\% CI) & $1.14[0.95,1.37]$ \\
\hline $\begin{array}{l}15 \text { Bitot's Spots Prevalence at } \\
\text { Longest Follow-up }\end{array}$ & 4 & & Risk Ratio (Fixed, 95\% CI) & $0.45[0.33,0.61]$ \\
\hline $\begin{array}{l}16 \text { Night Blindness Incidence at } \\
\text { Longest Follow-up }\end{array}$ & 1 & & Risk Ratio (Fixed, 95\% CI) & $0.53[0.28,0.99]$ \\
\hline $\begin{array}{l}17 \text { Night Blindness Prevalence at } \\
\text { Longest Follow-up }\end{array}$ & 2 & & Risk Ratio (Fixed, 95\% CI) & $0.32[0.21,0.50]$ \\
\hline $\begin{array}{l}18 \text { Xerophthalmia Incidence at } \\
\text { Longest Follow-up }\end{array}$ & 3 & & Risk Ratio (Fixed, 95\% CI) & $0.85[0.70,1.03]$ \\
\hline
\end{tabular}

Vitamin A supplementation for preventing morbidity and mortality in children from 6 months to 5 years of age (Review)

Copyright @ 201 I The Cochrane Collaboration. Published by John Wiley \& Sons, Ltd. 
19 Xerophthalmia Prevalence at Longest Follow-up

20 Vitamin A Deficient at Longest Follow-up

21 Vitamin A Serum Level at Longest Follow-up

22 Hospitalisation, Number of Children Hospitalised Once or More at Longest Follow-up

23 Hospitalisation due to Diarrhoea at Longest Follow-up

24 Hospitalisation due to Lower Respiratory Tract Infection at Longest Follow-up

25 Side effect - Bulging Fontanelle 26 Side effect - Vomiting

\section{up.

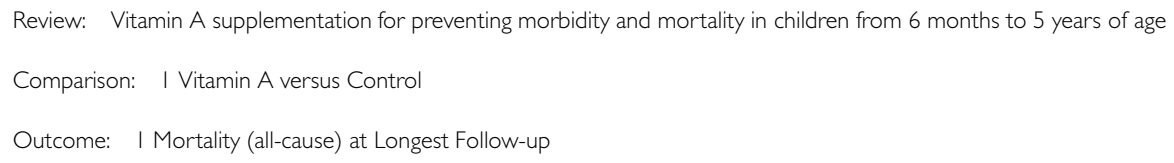

Analysis I.I. Comparison I Vitamin A versus Control, Outcome I Mortality (all-cause) at Longest Follow-

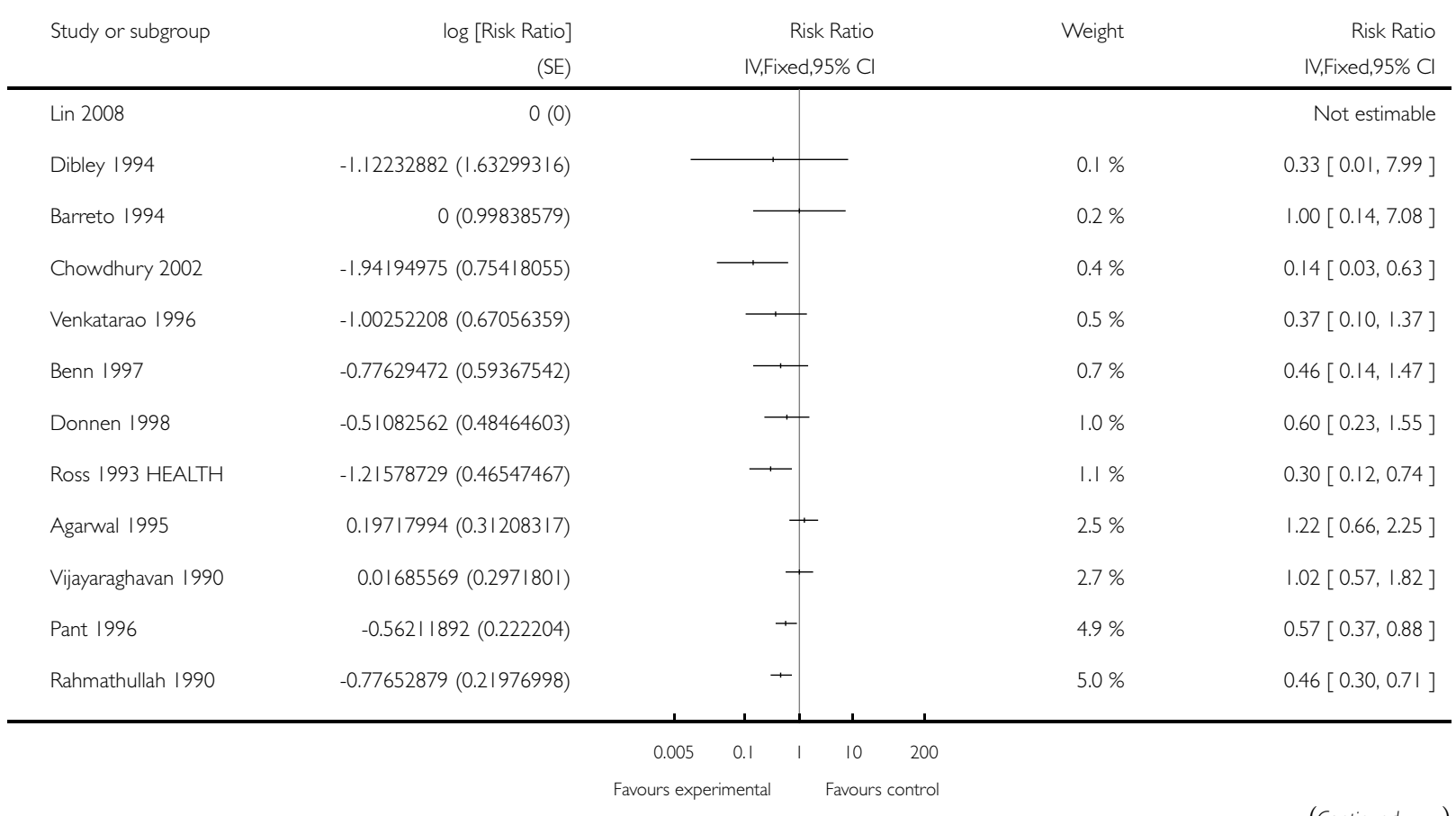




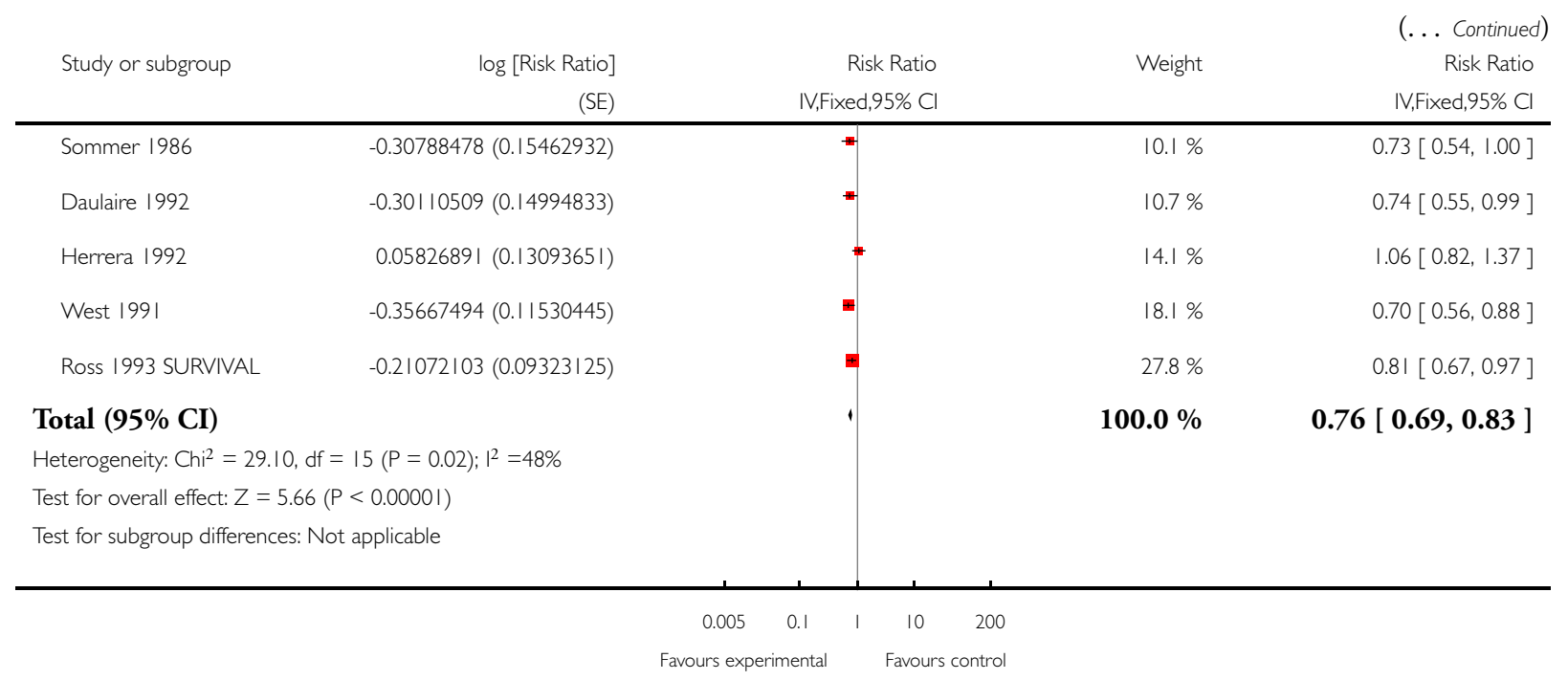

\section{Analysis I.2. Comparison I Vitamin A versus Control, Outcome 2 Mortality (all-cause) at Longest Follow- up (by Age).}

Review: Vitamin A supplementation for preventing morbidity and mortality in children from 6 months to 5 years of age

Comparison: I Vitamin A versus Control

Outcome: 2 Mortality (all-cause) at Longest Follow-up (by Age)

Study or subgroup $\quad \log [$ Risk Ratio] Risk Ratio Risk Ratio

(SE) IV,Fixed,95\% Cl

IV,Fixed,95\% Cl

\begin{tabular}{lr}
\hline $\begin{array}{l}\text { | } 6 \text { to } 12 \text { months old } \\
\text { Benn } 1997\end{array}$ & $-0.77629472(0.59367542)$ \\
Rahmathullah 1990 & $-1.27296568(0.57282345)$ \\
Daulaire 1992 & $-0.67334455(0.2774$ |3) \\
West 199| & $-0.24846136(0.23890578)$
\end{tabular}

Subtotal (95\% CI)
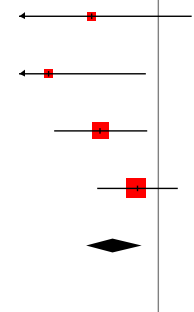

$100.0 \%$

$7.8 \%$

$8.4 \%$

$35.7 \%$

$48.1 \%$

$0.59[0.43,0.82]$

(Continued....) 


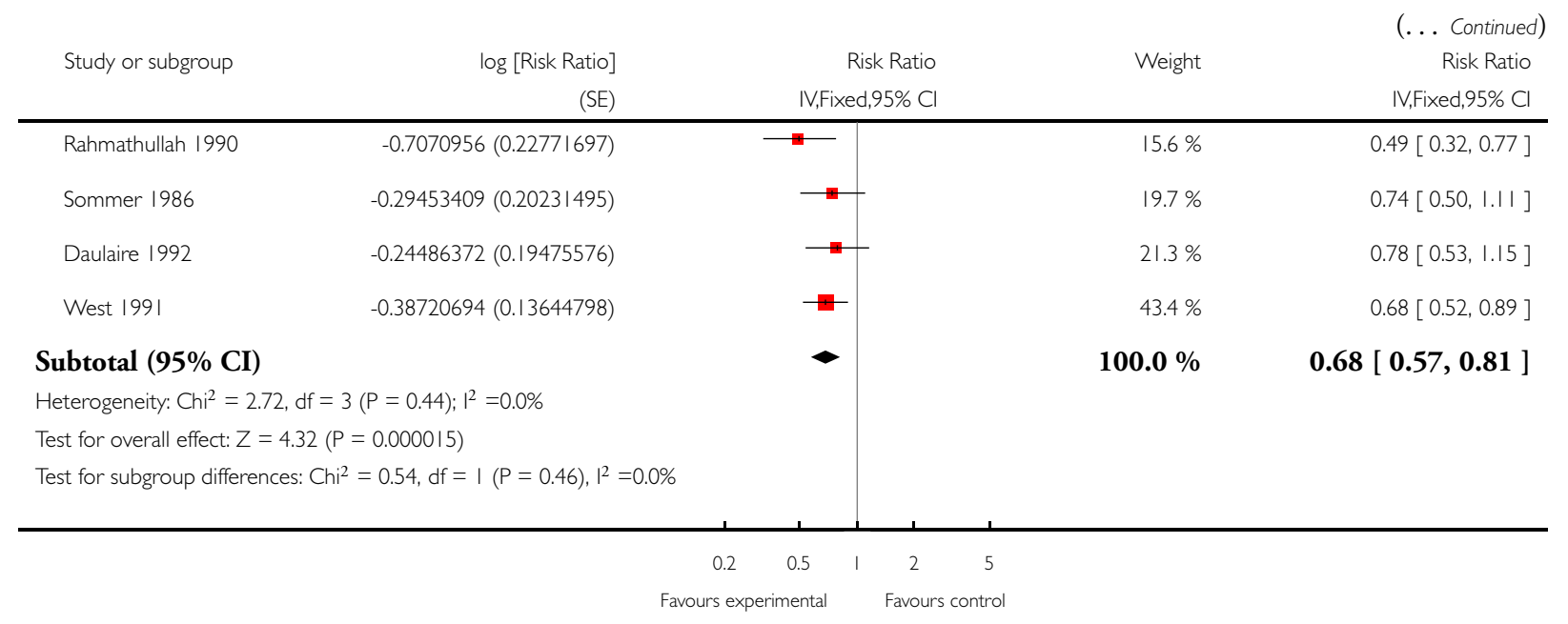

\section{Analysis I.3. Comparison I Vitamin A versus Control, Outcome 3 Mortality (all-cause) at Longest Follow- up (by Sex).}

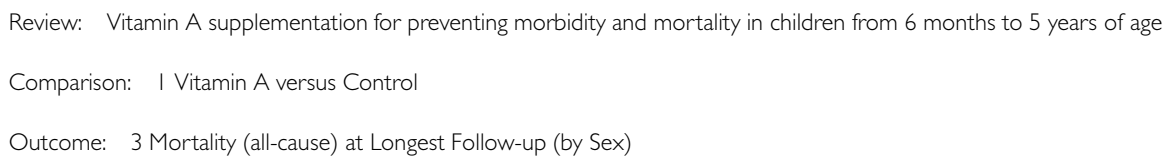

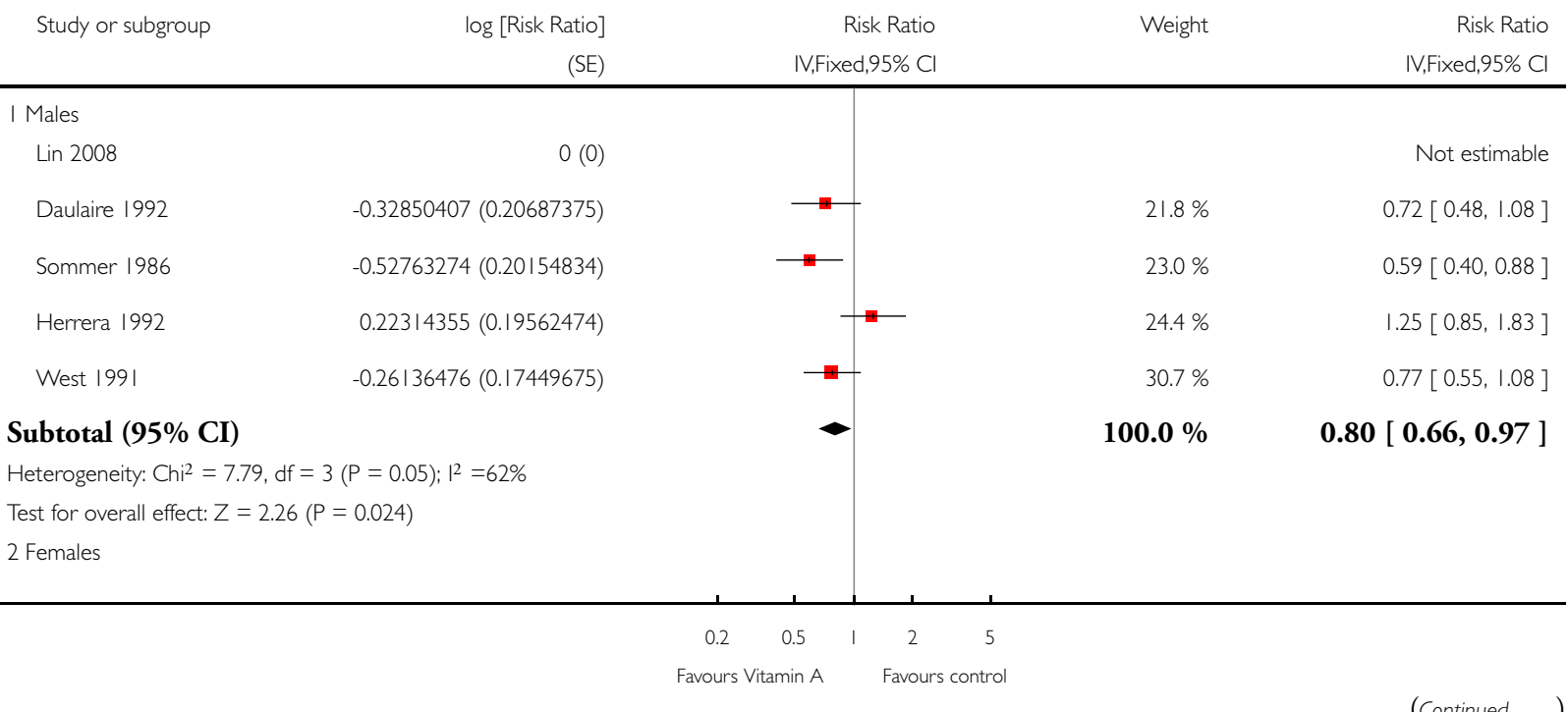




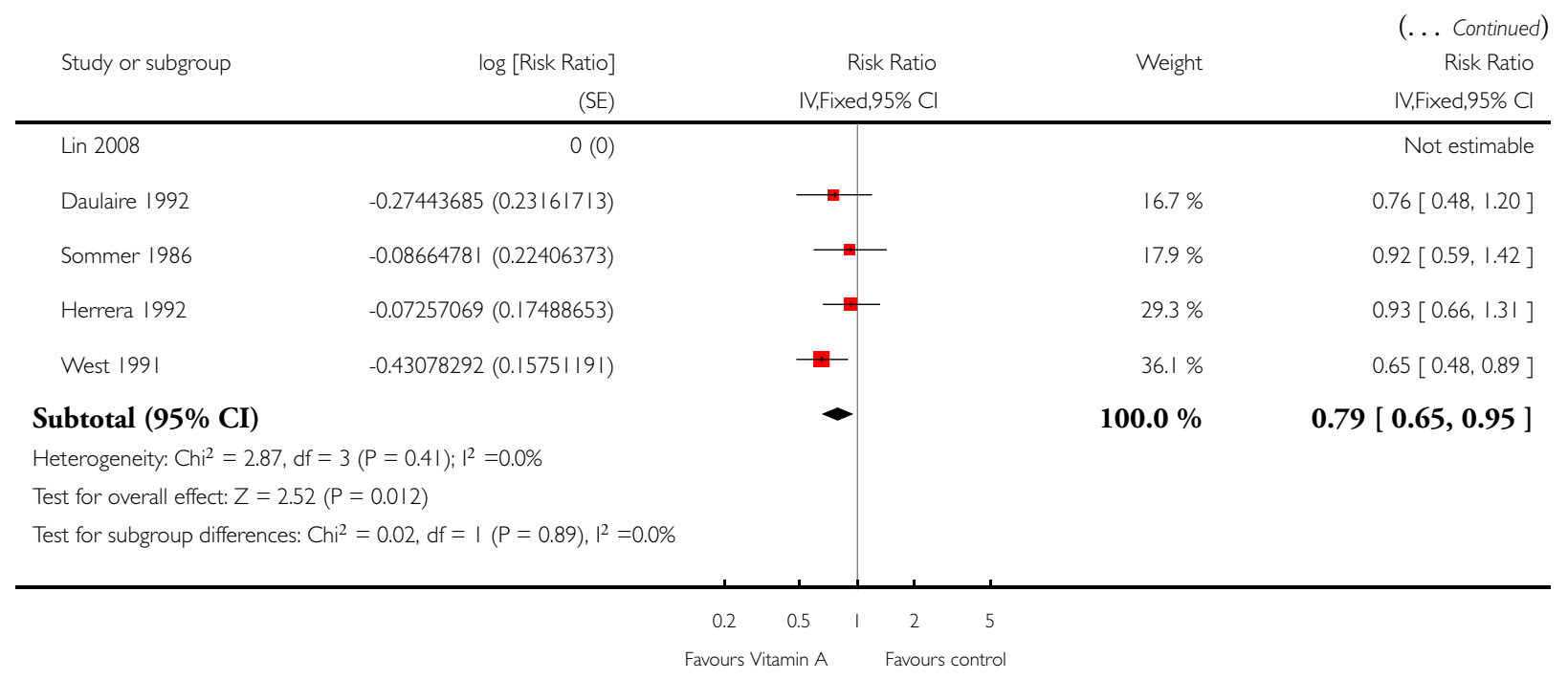

\section{Analysis I.4. Comparison I Vitamin A versus Control, Outcome 4 Mortality (all-cause) at Longest Follow- up (Sensitivity Analysis including DEVTA trial).}

Review: Vitamin A supplementation for preventing morbidity and mortality in children from 6 months to 5 years of age

Comparison: I Vitamin A versus Control

Outcome: 4 Mortality (all-cause) at Longest Follow-up (Sensitivity Analysis including DEVTA trial)

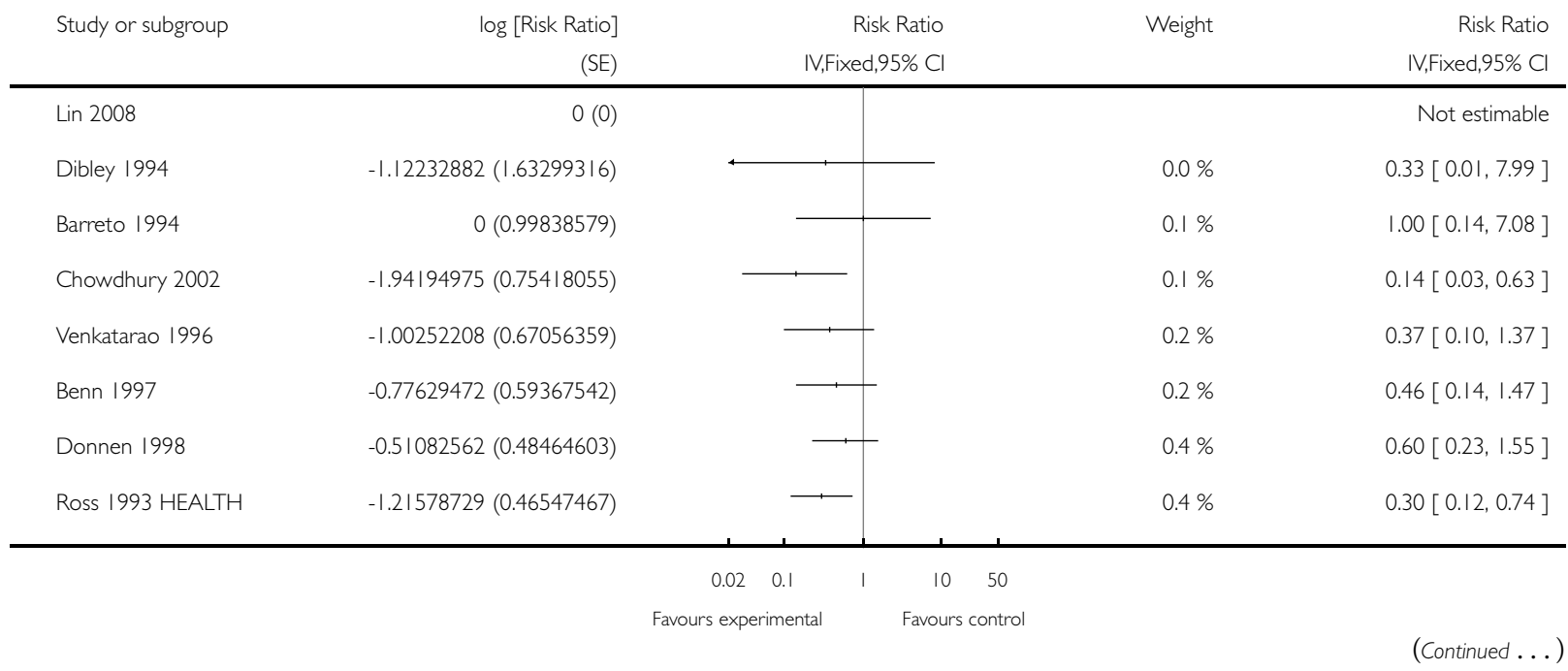




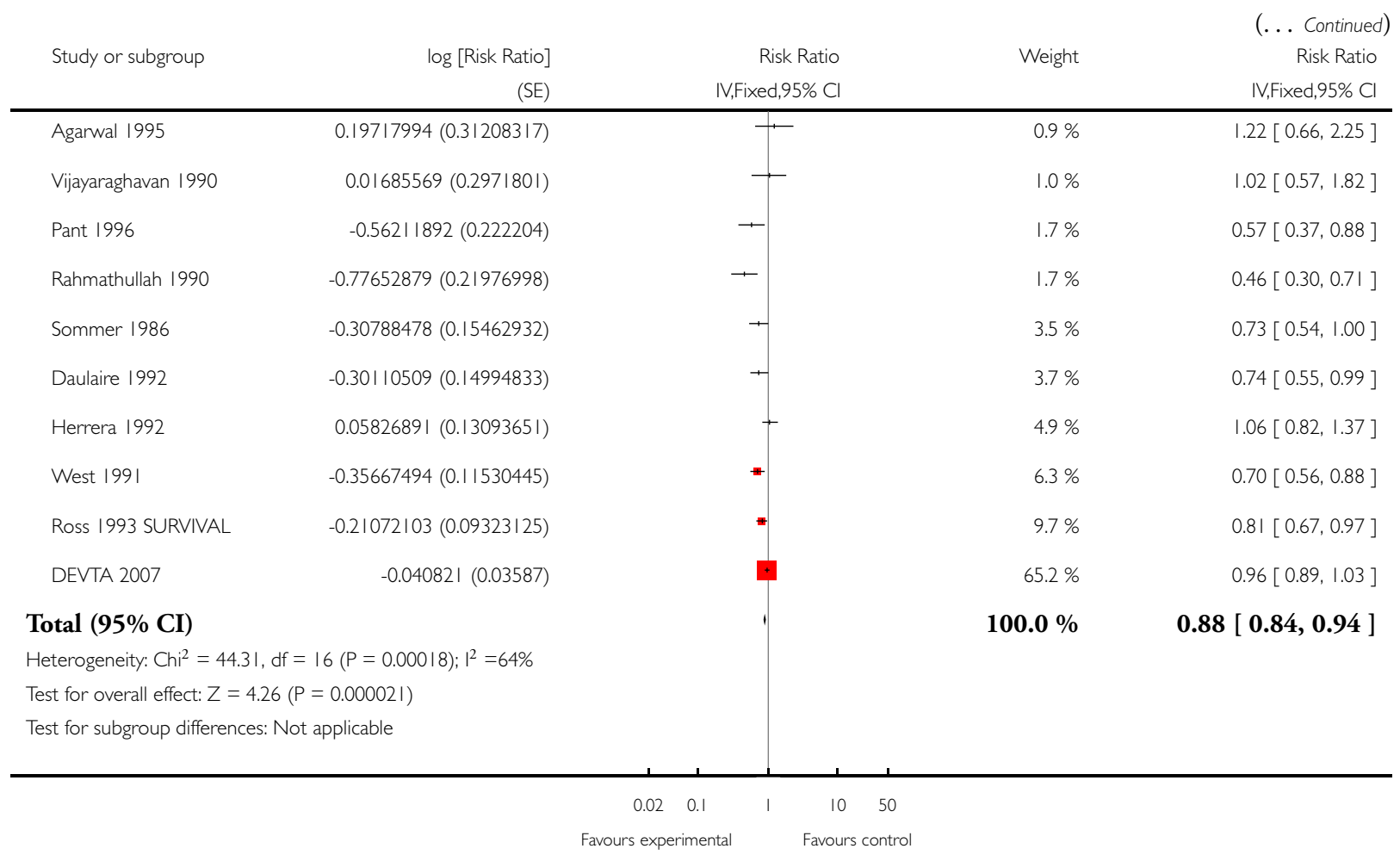


Analysis I.5. Comparison I Vitamin A versus Control, Outcome 5 Mortality due to Diarrhoea at Longest Follow-up.

Review: Vitamin A supplementation for preventing morbidity and mortality in children from 6 months to 5 years of age

Comparison: I Vitamin A versus Control

Outcome: 5 Mortality due to Diarrhoea at Longest Follow-up

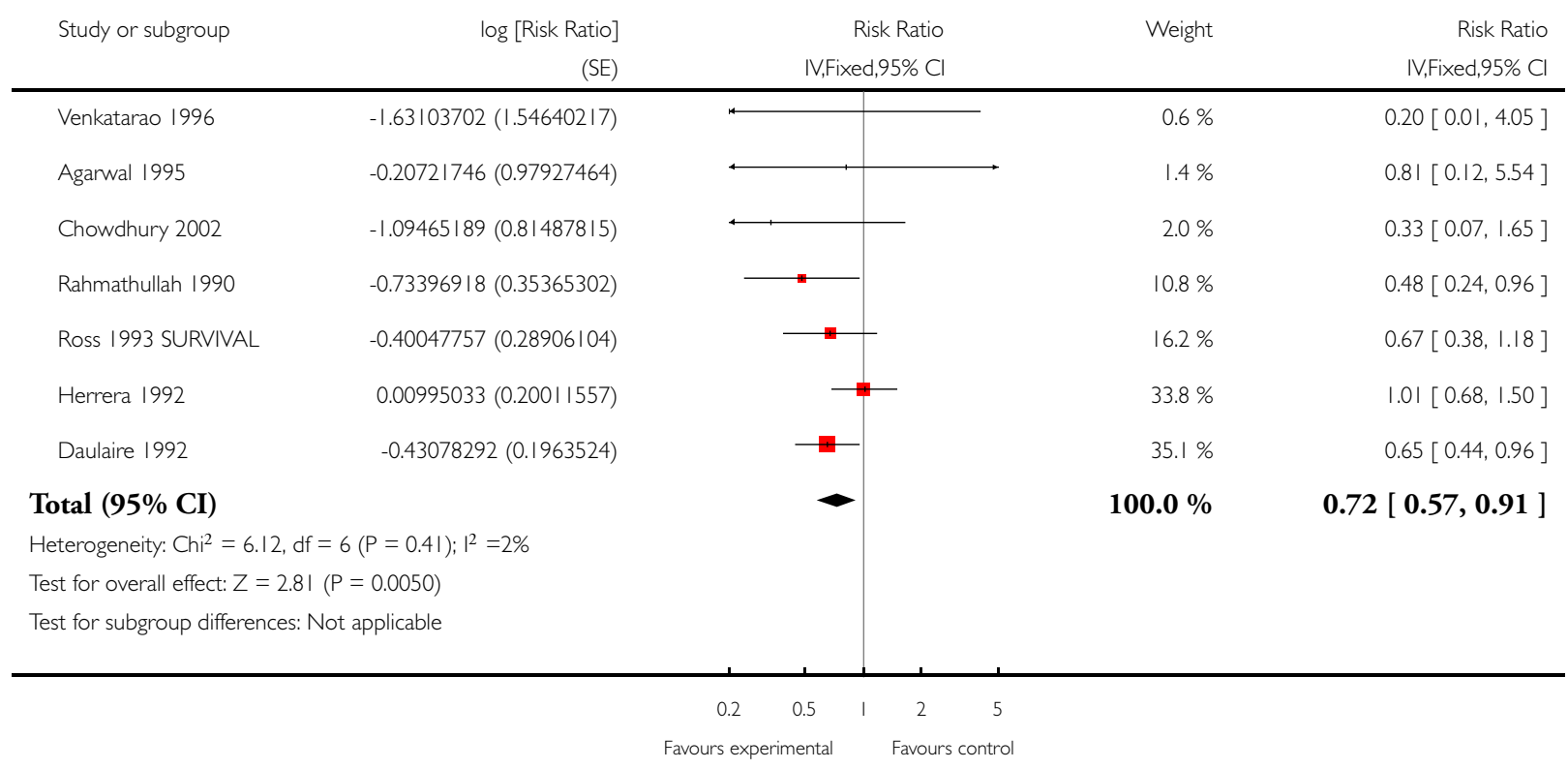




\section{Analysis I.6. Comparison I Vitamin A versus Control, Outcome 6 Mortality due to Measles at Longest} Follow-up.

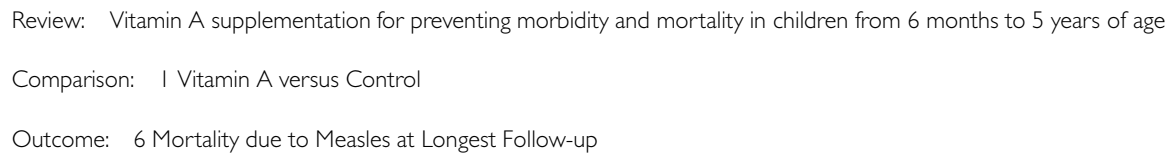

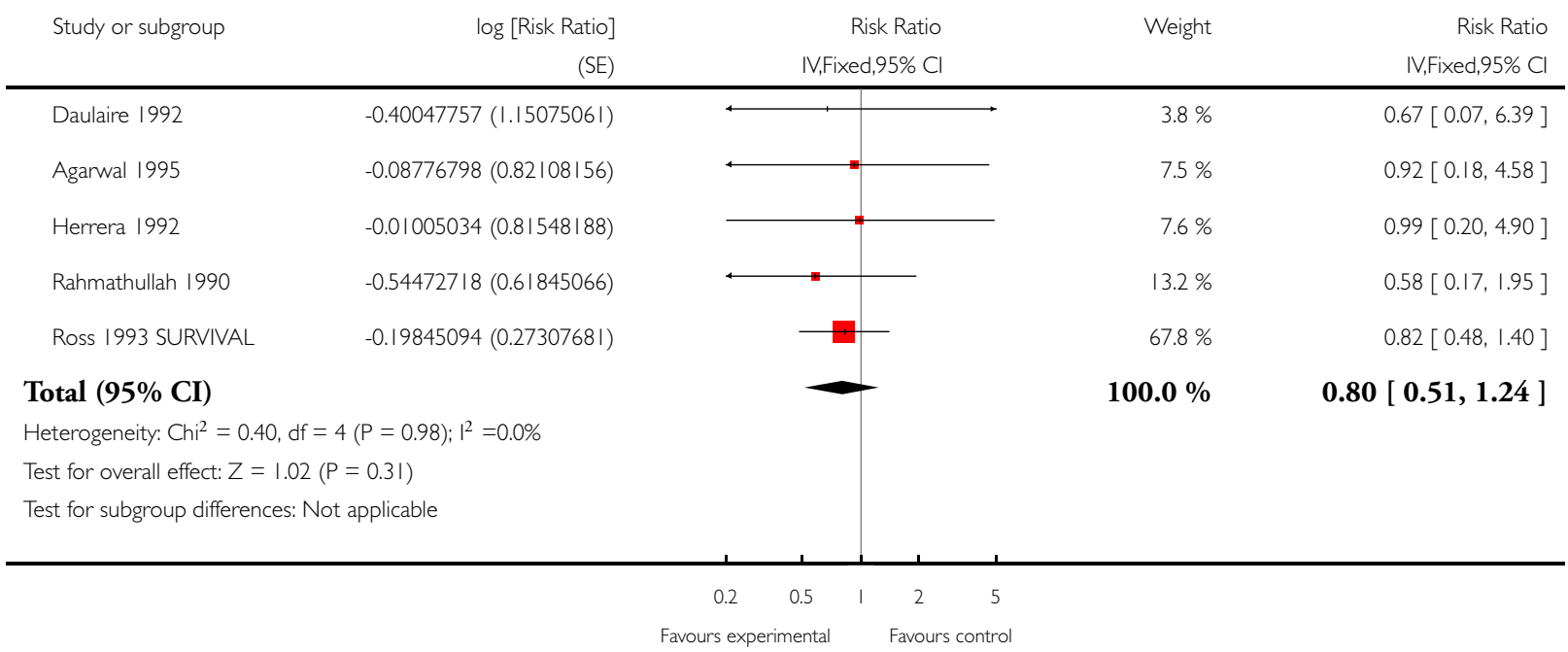


Analysis I.7. Comparison I Vitamin A versus Control, Outcome 7 Mortality due to Meningitis at Longest Follow-up.

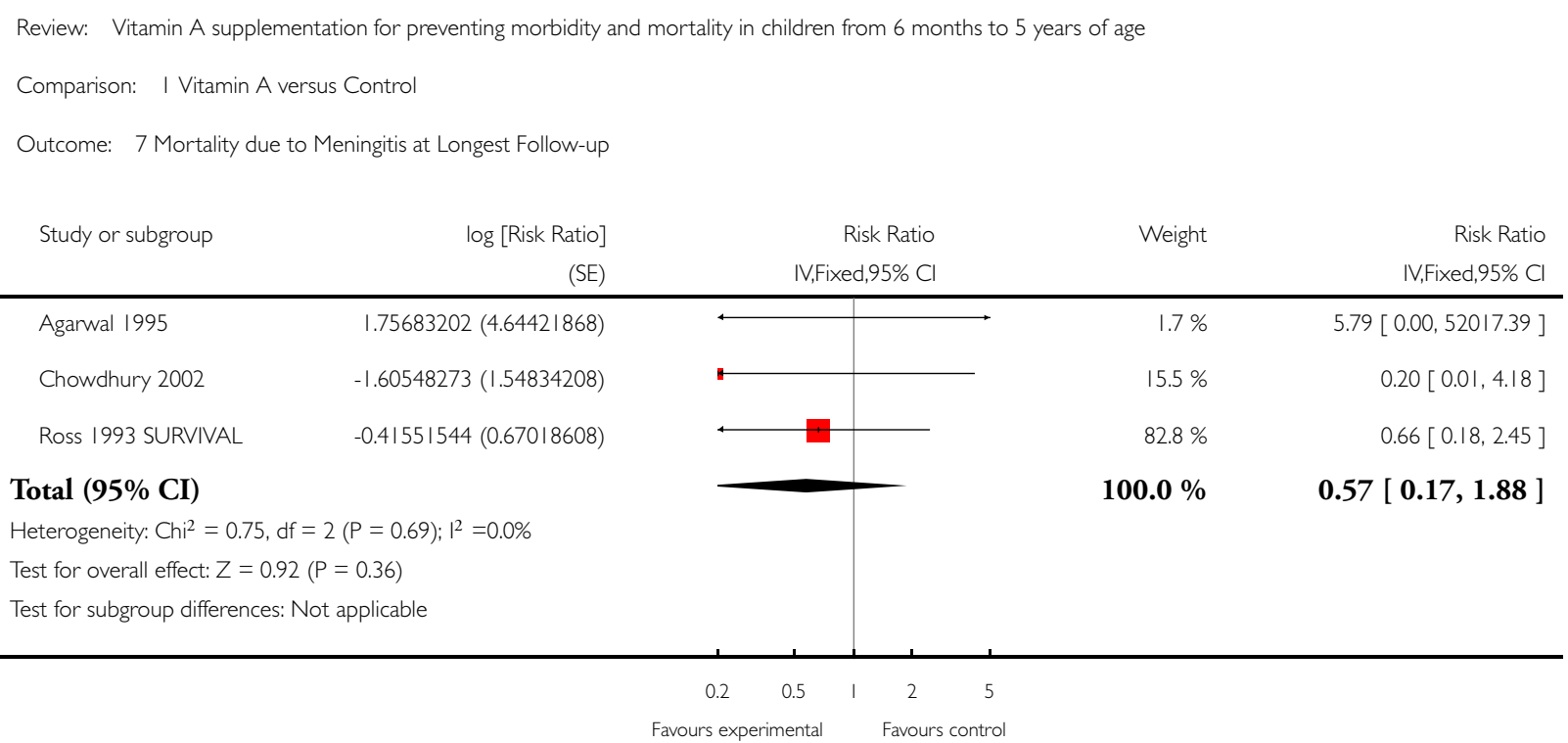


Analysis I.8. Comparison I Vitamin A versus Control, Outcome 8 Mortality due to LRTI at Longest Followup.

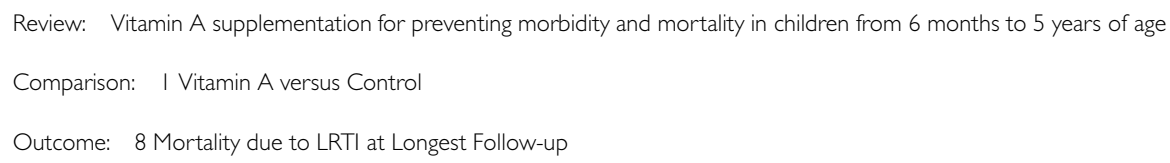

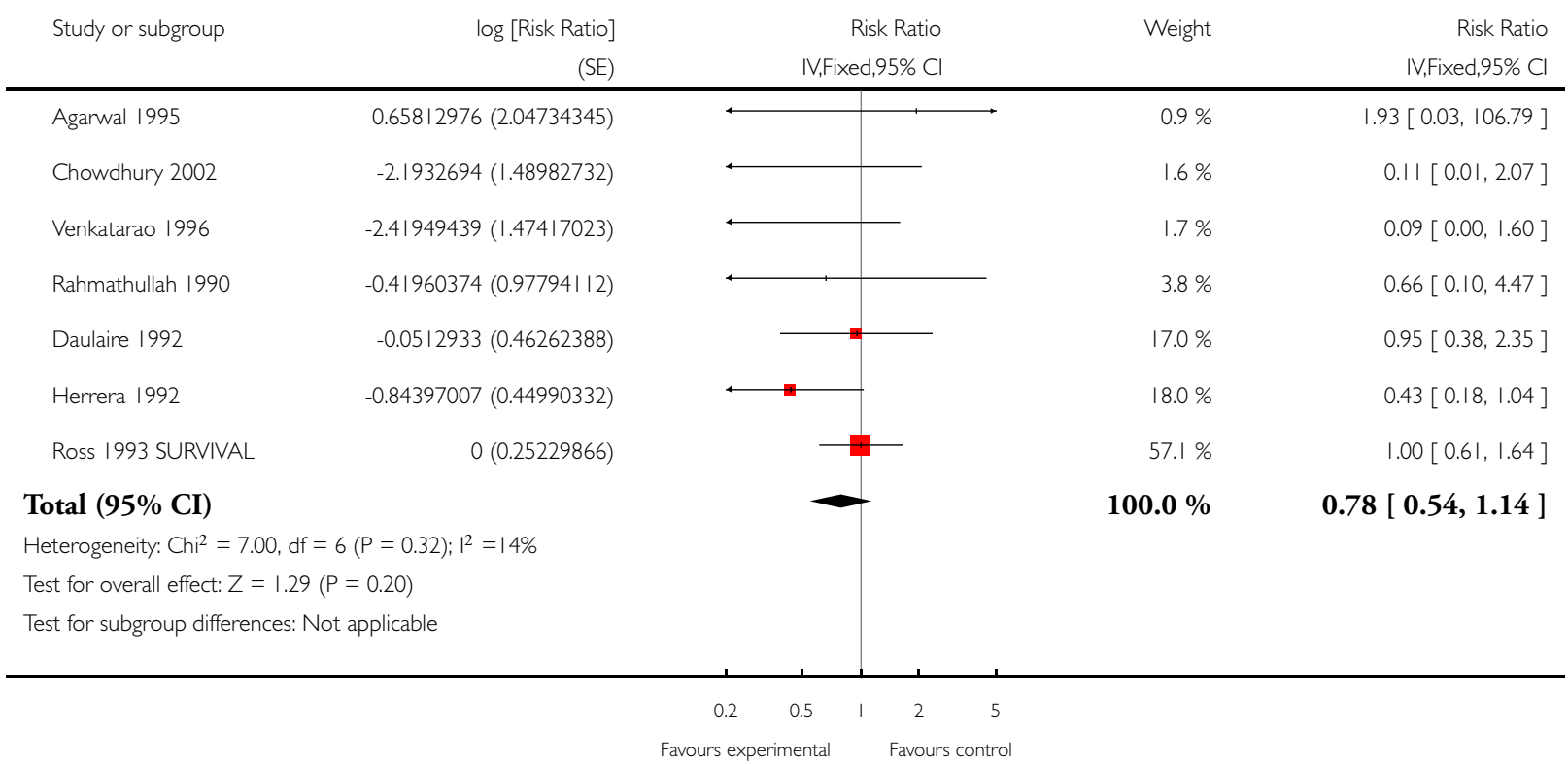




\section{Analysis I.9. Comparison I Vitamin A versus Control, Outcome 9 Diarrhoea Incidence at Longest Follow-} up.

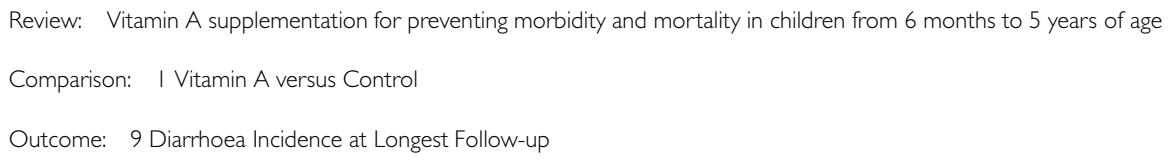

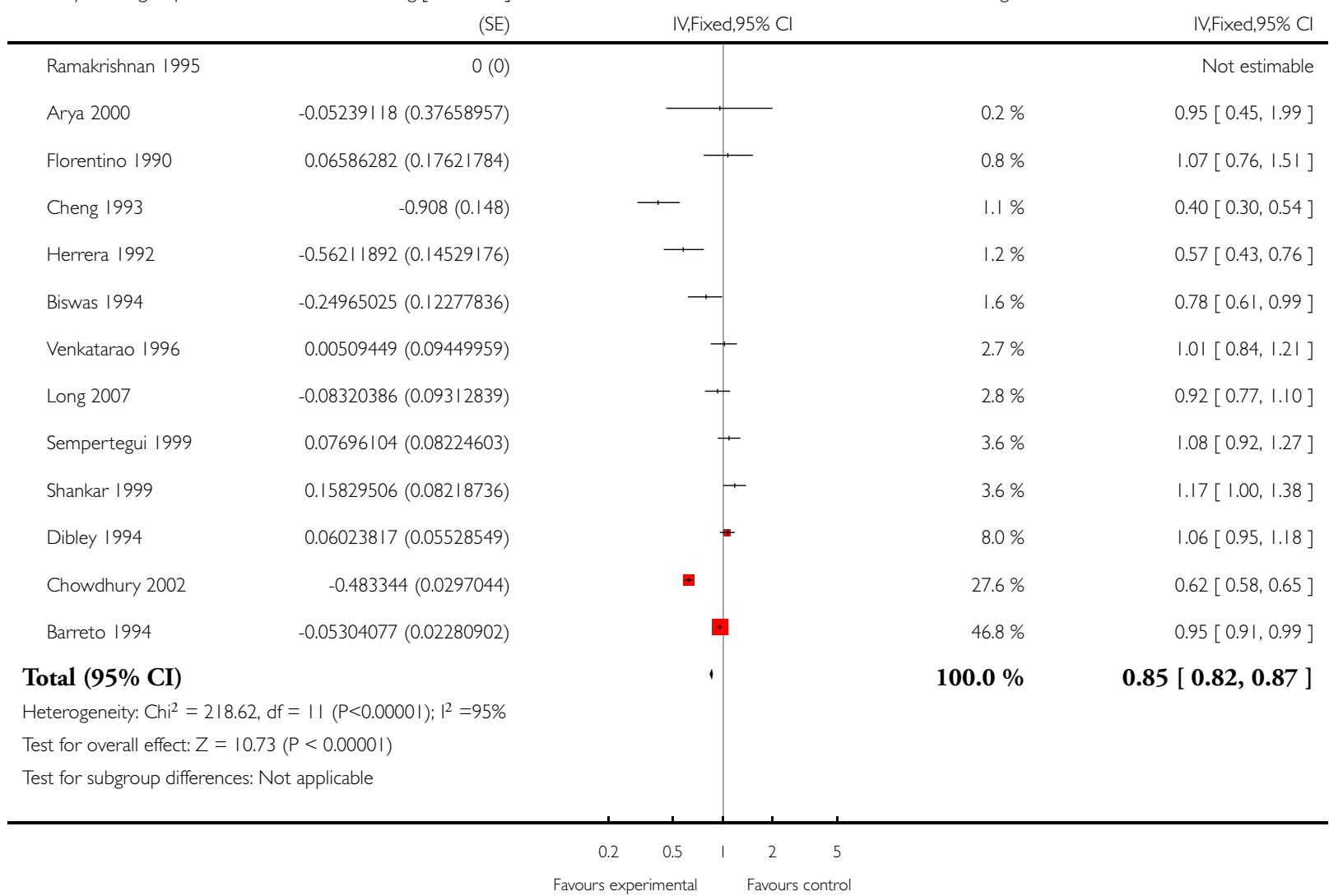


Analysis I.10. Comparison I Vitamin A versus Control, Outcome I0 Diarrhoea Prevalence at Longest Follow-up.

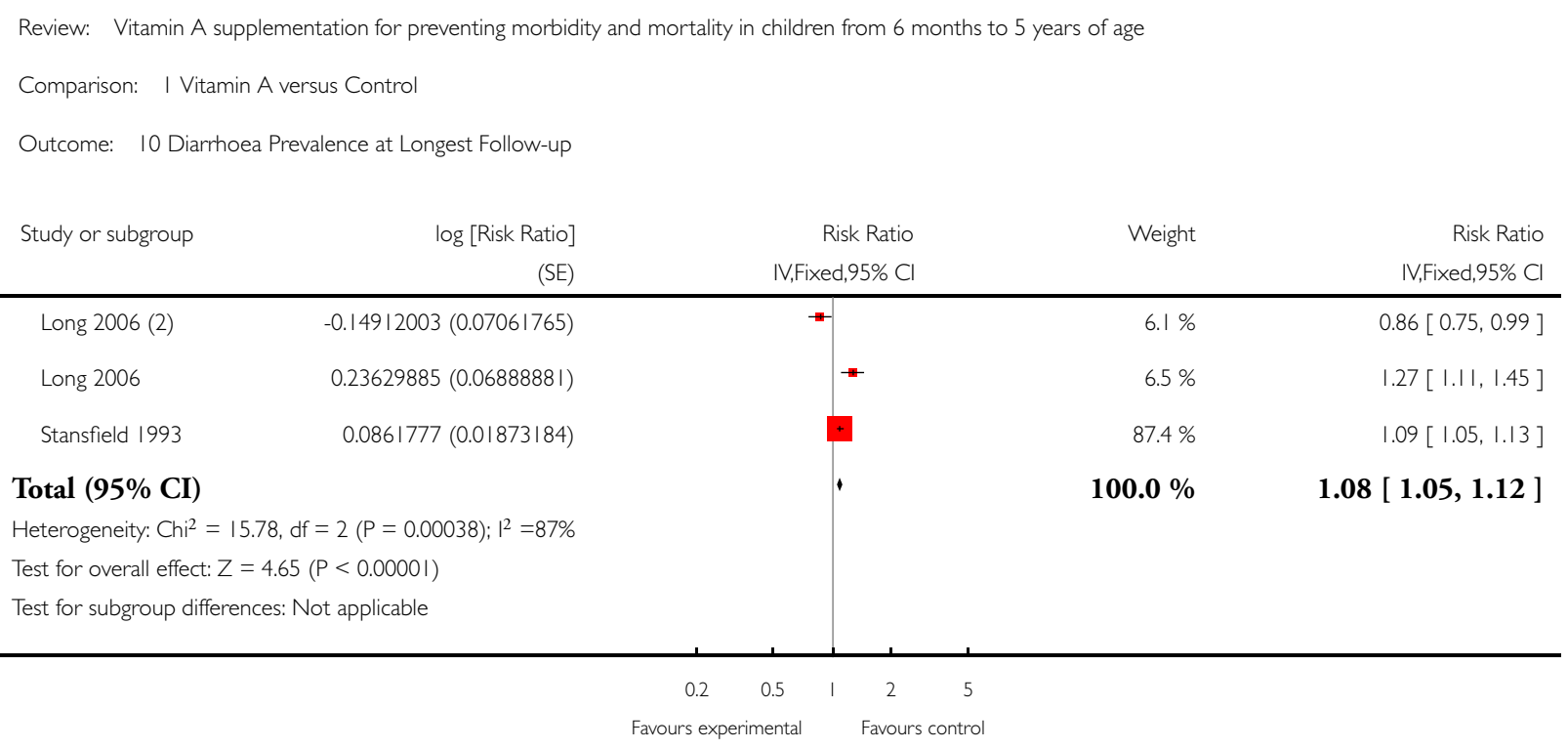


Analysis I.I I. Comparison I Vitamin A versus Control, Outcome I I Measles Incidence at Longest Followup.

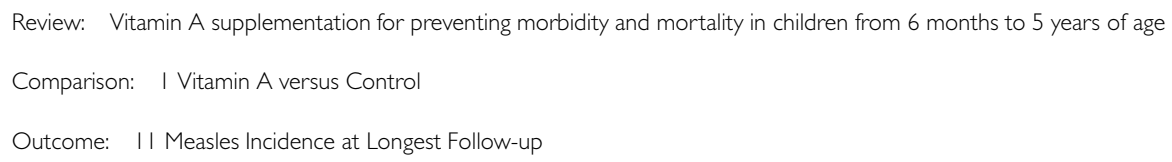

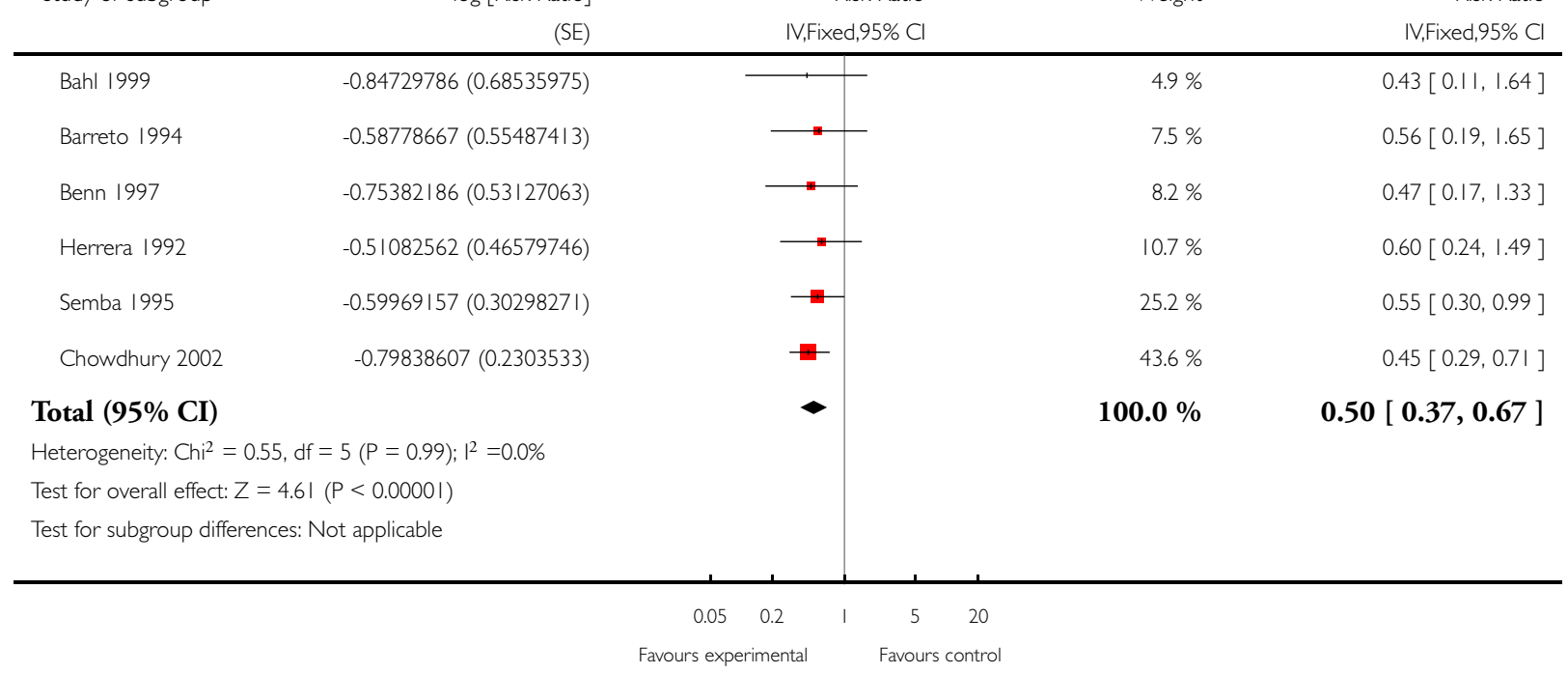




\section{Analysis I.12. Comparison I Vitamin A versus Control, Outcome I 2 Malaria Incidence at Longest Follow-} up.

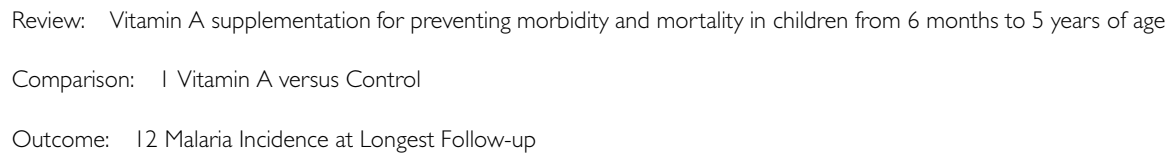

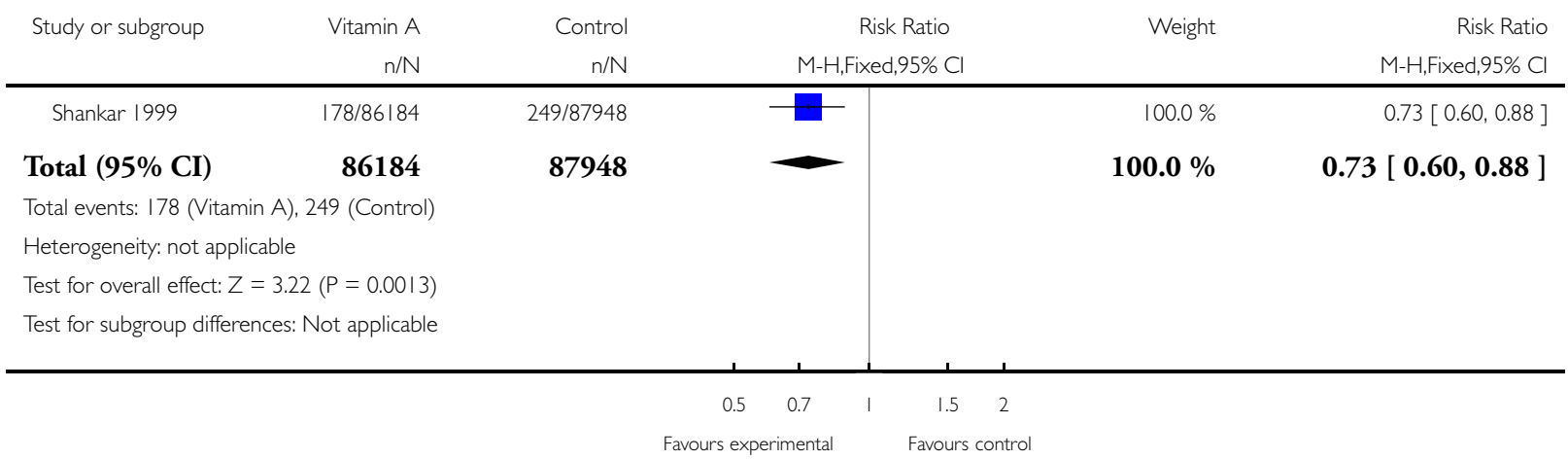

Analysis I.13. Comparison I Vitamin A versus Control, Outcome I3 Malaria Prevalence at Longest Followup.

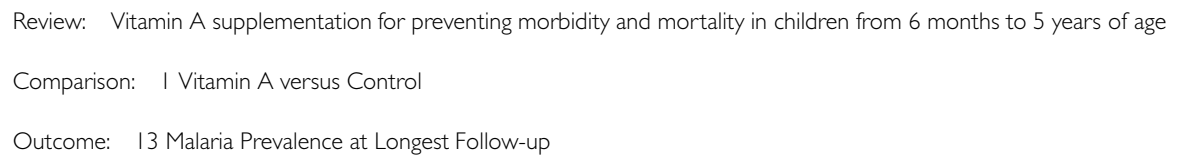

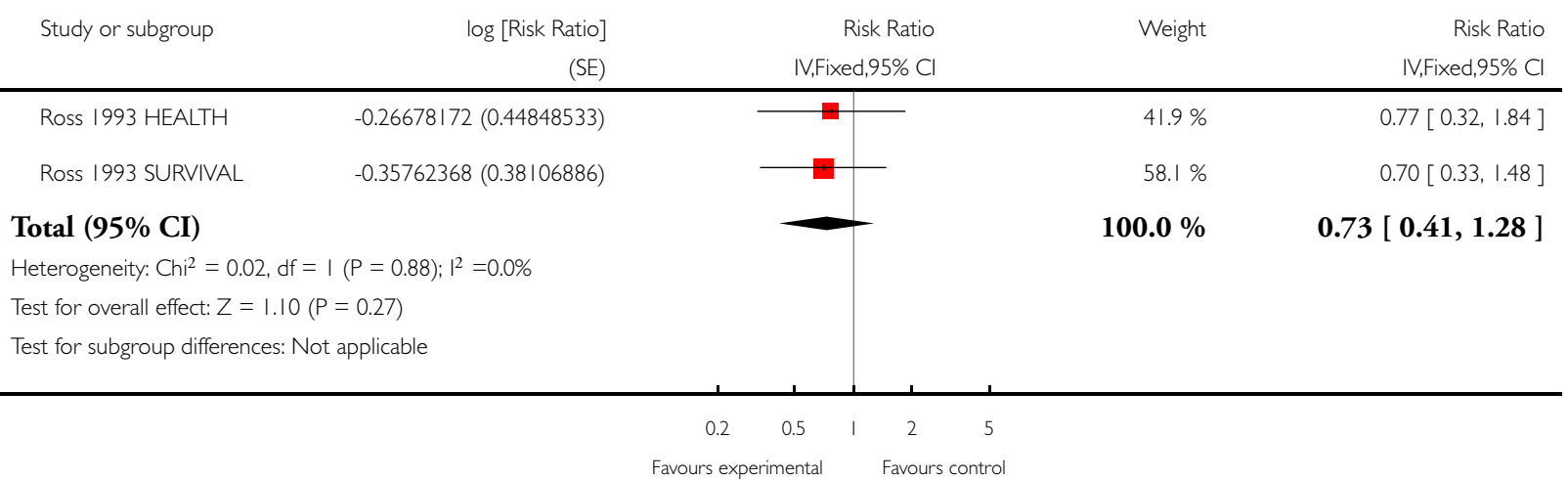




\section{Analysis I.I4. Comparison I Vitamin A versus Control, Outcome I4 Lower Respiratory Tract Infection Incidence at Longest Follow-up.}

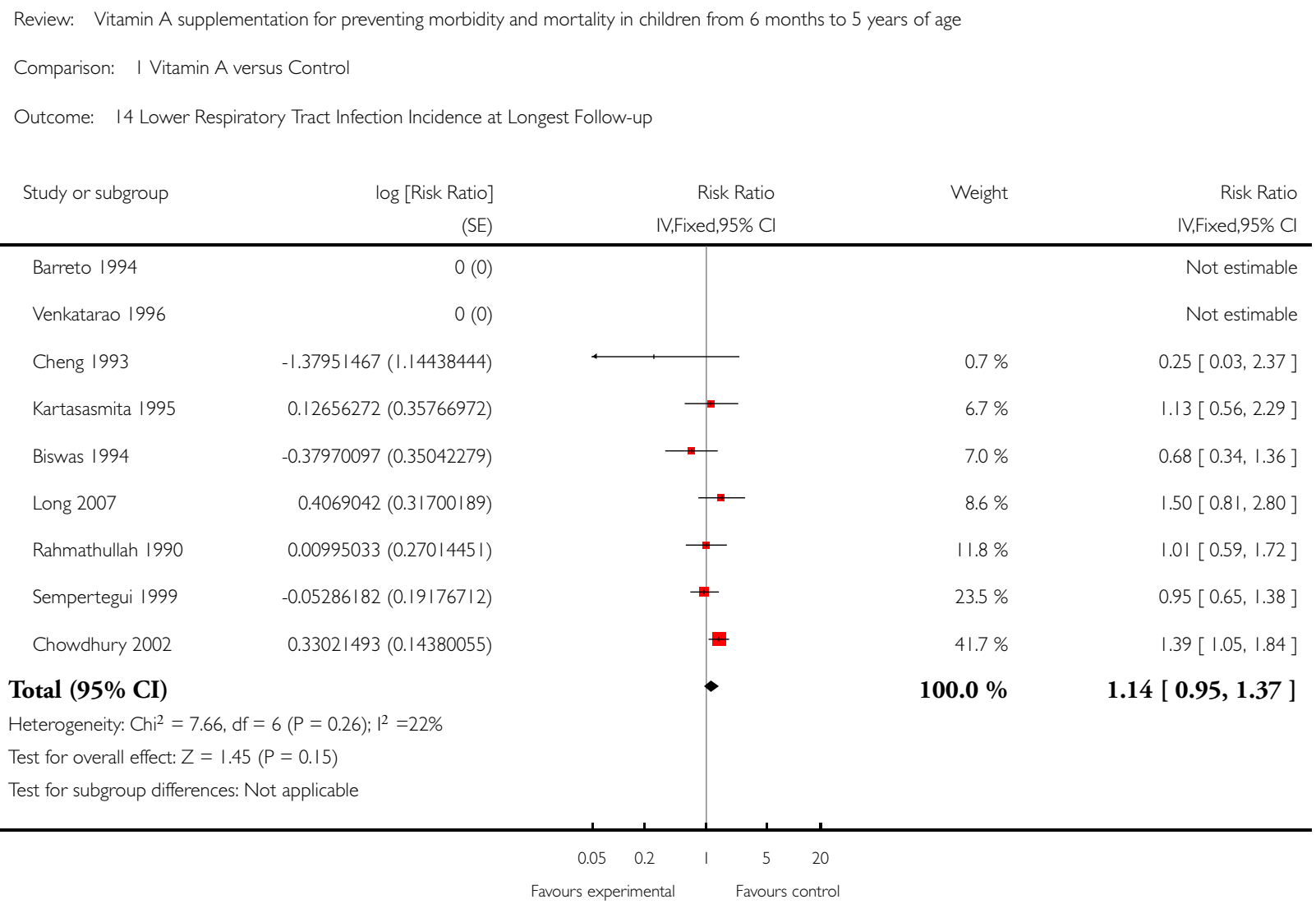




\section{Analysis I.I5. Comparison I Vitamin A versus Control, Outcome I5 Bitot's Spots Prevalence at Longest Follow-up.}

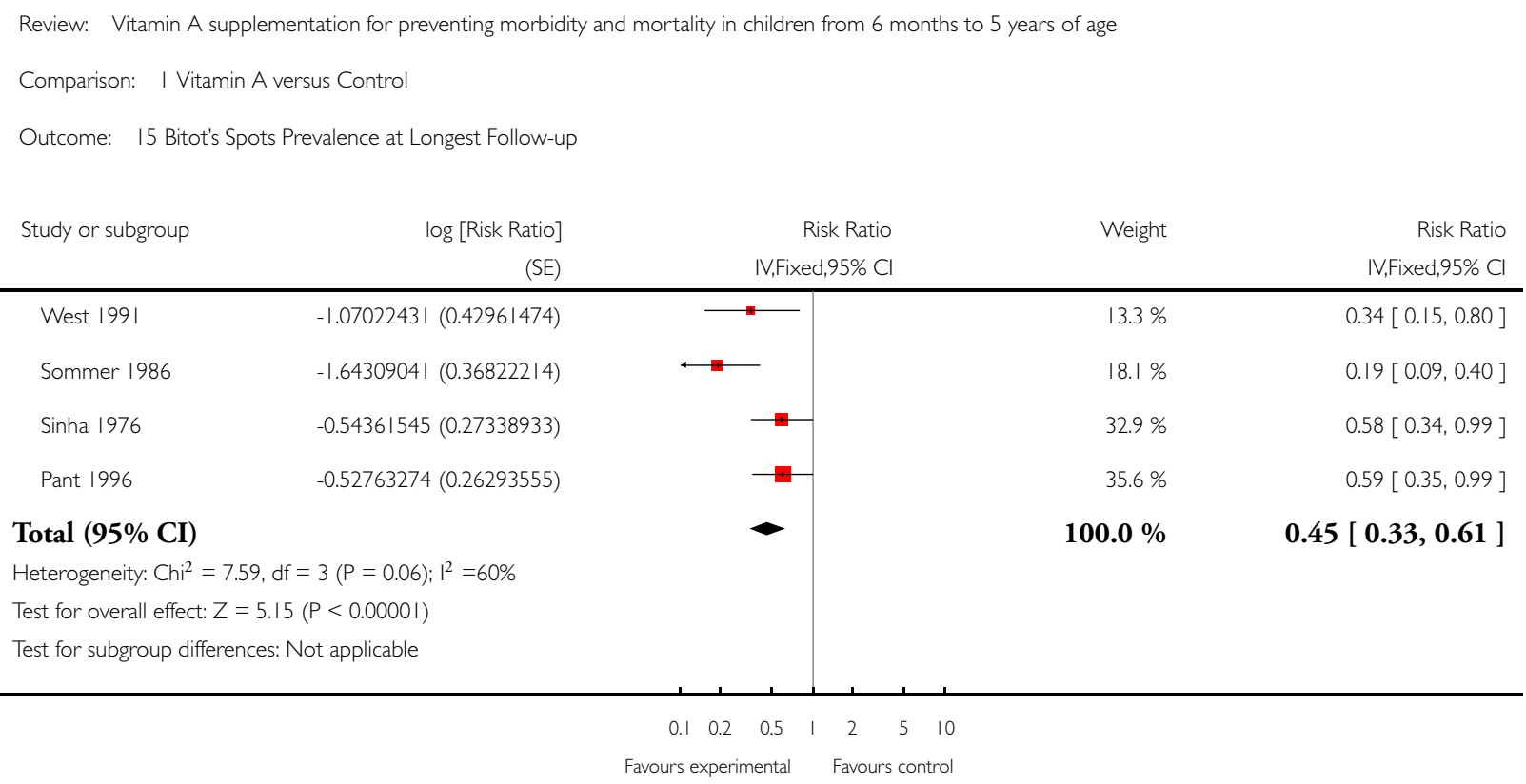

\section{Analysis I.16. Comparison I Vitamin A versus Control, Outcome I6 Night Blindness Incidence at Longest Follow-up.}

Review: Vitamin A supplementation for preventing morbidity and mortality in children from 6 months to 5 years of age

Comparison: I Vitamin A versus Control

Outcome: 16 Night Blindness Incidence at Longest Follow-up

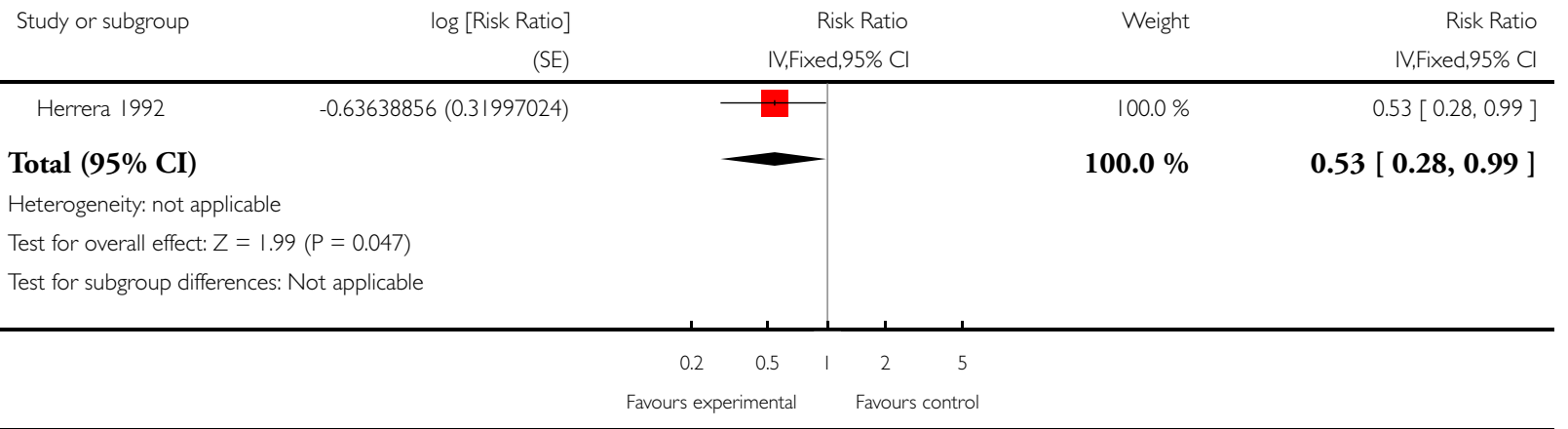




\section{Analysis I.17. Comparison I Vitamin A versus Control, Outcome 17 Night Blindness Prevalence at Longest Follow-up.}

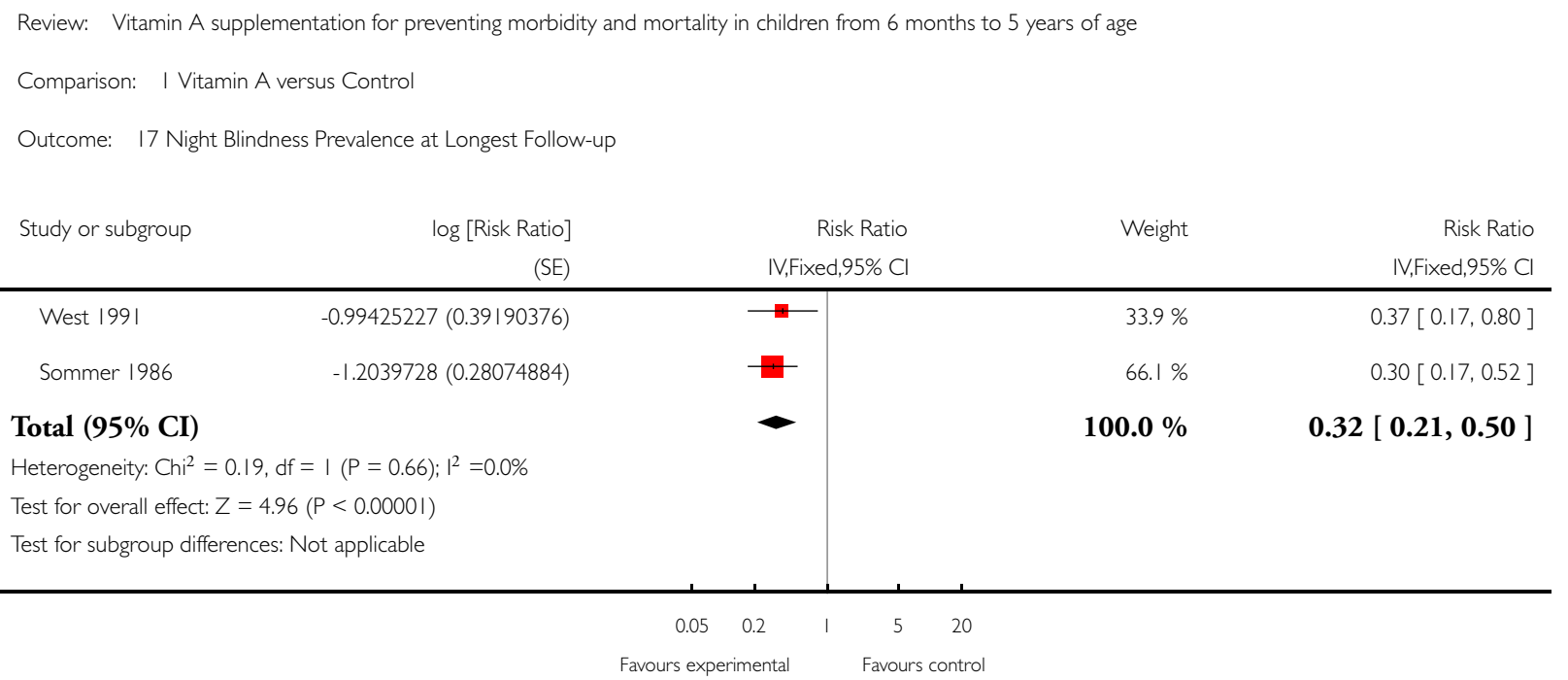




\section{Analysis I.18. Comparison I Vitamin A versus Control, Outcome 18 Xerophthalmia Incidence at Longest Follow-up.}

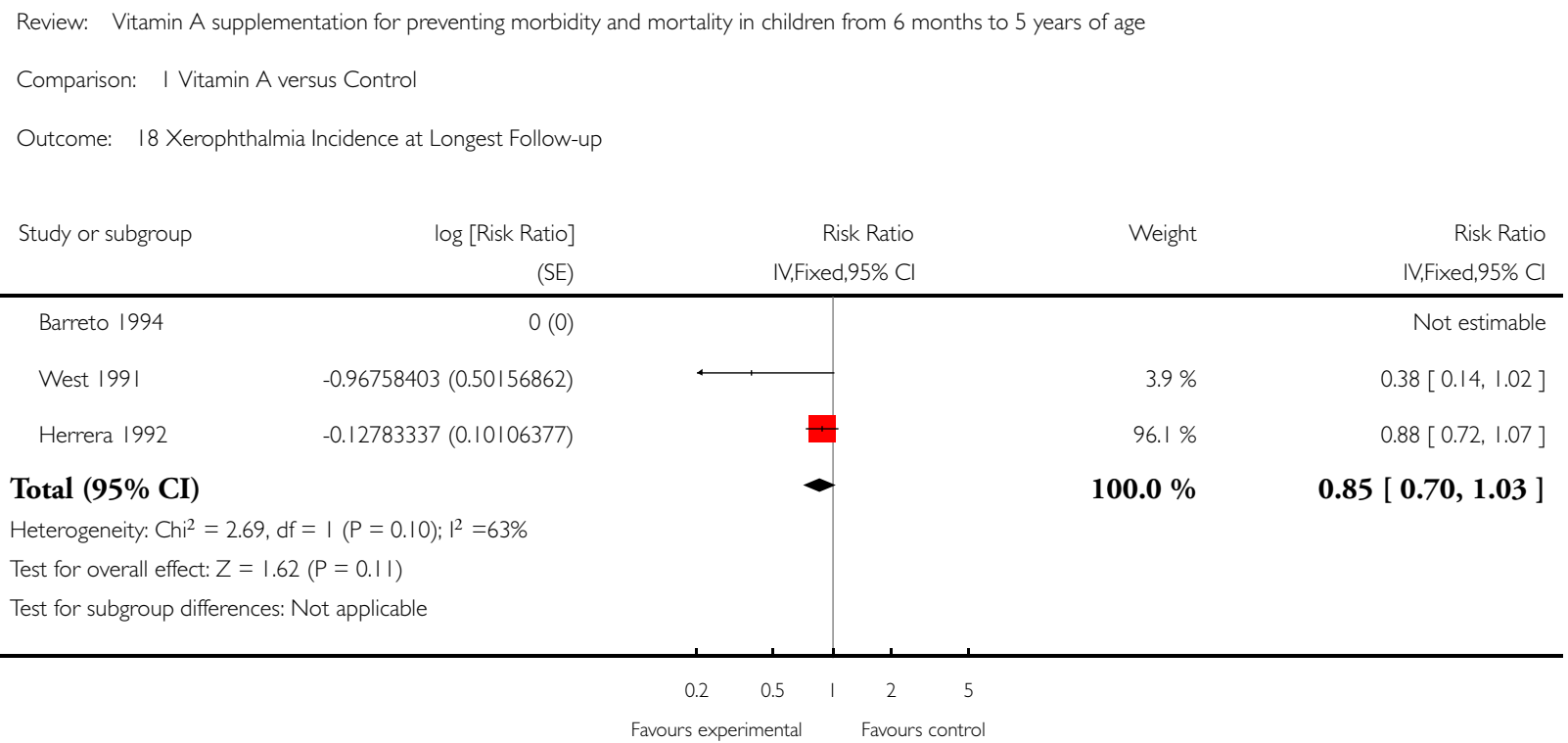

\section{Analysis I.19. Comparison I Vitamin A versus Control, Outcome I9 Xerophthalmia Prevalence at Longest Follow-up.}

Review: Vitamin A supplementation for preventing morbidity and mortality in children from 6 months to 5 years of age

Comparison: I Vitamin A versus Control

Outcome: 19 Xerophthalmia Prevalence at Longest Follow-up

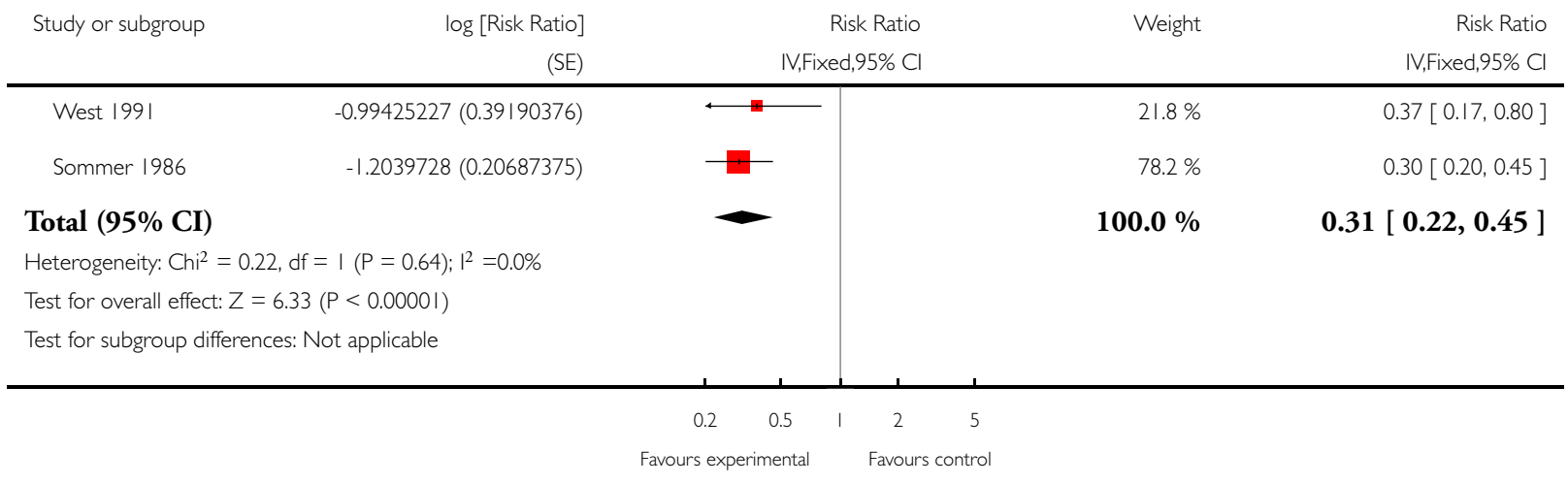




\section{Analysis I.20. Comparison I Vitamin A versus Control, Outcome 20 Vitamin A Deficient at Longest}

Follow-up.

Review: Vitamin A supplementation for preventing morbidity and mortality in children from 6 months to 5 years of age

Comparison: I Vitamin A versus Control

Outcome: 20 Vitamin A Deficient at Longest Follow-up






\section{Analysis I.21. Comparison I Vitamin A versus Control, Outcome 2I Vitamin A Serum Level at Longest Follow-up.}

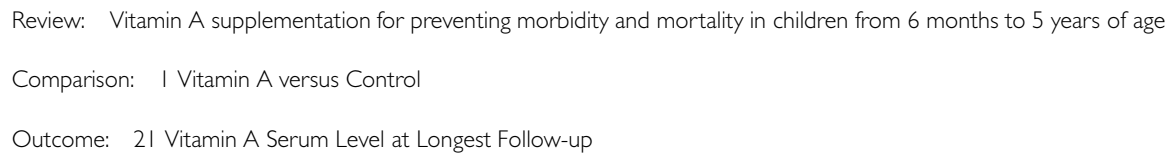

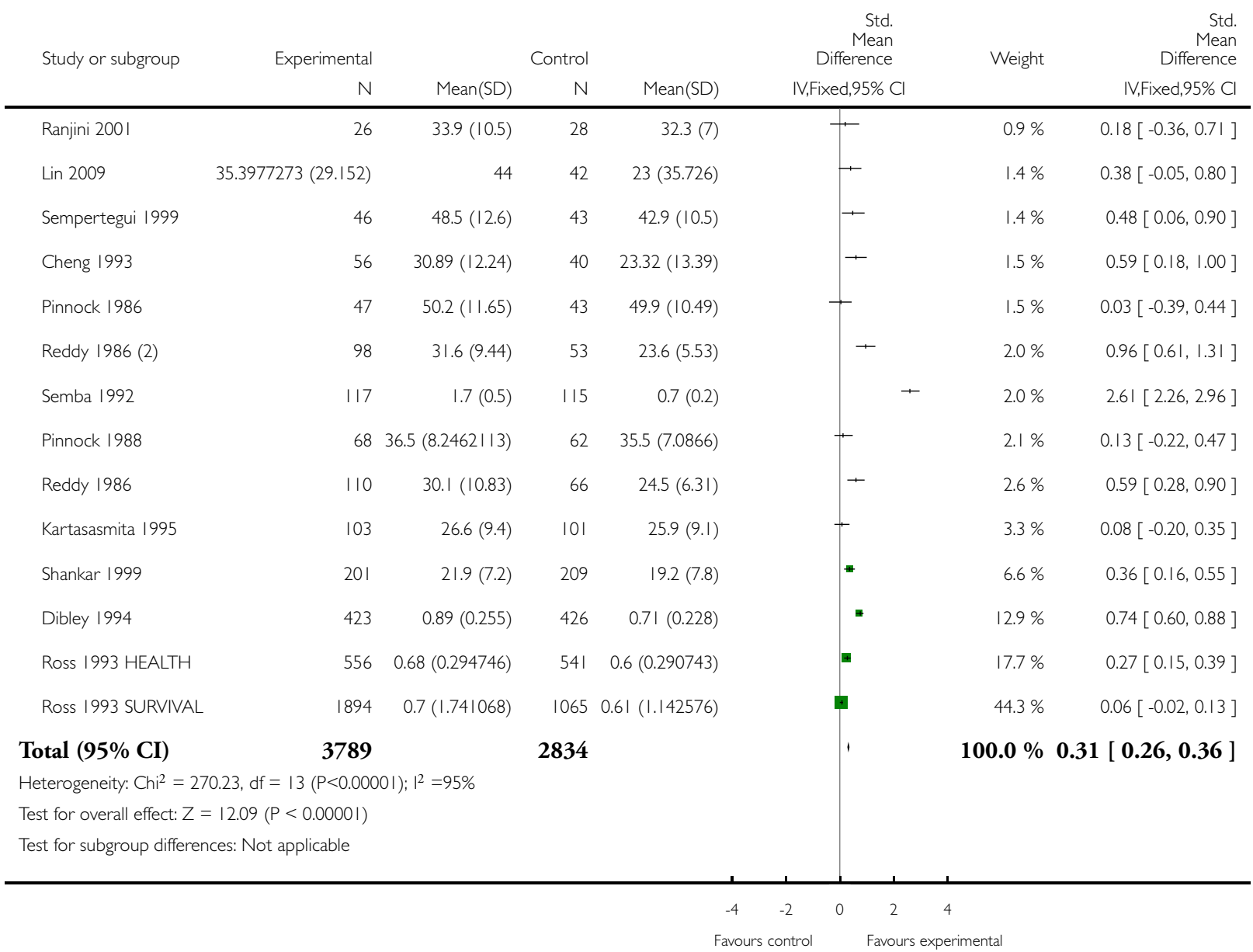




\section{Analysis I.22. Comparison I Vitamin A versus Control, Outcome 22 Hospitalisation, Number of Children Hospitalised Once or More at Longest Follow-up.}

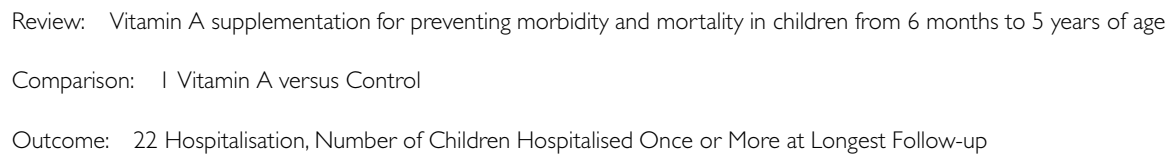

\begin{tabular}{|c|c|c|c|c|c|c|c|}
\hline \multirow[t]{2}{*}{ Study or subgroup } & Vitamin A & Control & \multicolumn{3}{|r|}{ Risk Ratio } & \multirow[t]{2}{*}{ Weight } & Risk Ratio \\
\hline & $\mathrm{n} / \mathrm{N}$ & $\mathrm{n} / \mathrm{N}$ & & & -ixed,95\% Cl & & M-H,Fixed,95\% Cl \\
\hline Ross 1993 HEALTH & $27 / 596$ & $42 / 589$ & & & & $100.0 \%$ & $0.64[0.40,1.02]$ \\
\hline Total (95\% CI) & 596 & 589 & & & & $100.0 \%$ & $0.64[0.40,1.02]$ \\
\hline \multicolumn{8}{|c|}{ Total events: 27 (Vitamin A), 42 (Control) } \\
\hline \multicolumn{8}{|c|}{ Heterogeneity: not applicable } \\
\hline \multicolumn{8}{|c|}{ Test for overall effect: $Z=1.89(P=0.058)$} \\
\hline \multicolumn{8}{|c|}{ Test for subgroup differences: Not applicable } \\
\hline & & & 0.5 & 0.7 & 1.5 & 2 & \\
\hline
\end{tabular}

\section{Analysis I.23. Comparison I Vitamin A versus Control, Outcome 23 Hospitalisation due to Diarrhoea at} Longest Follow-up.

Review: Vitamin A supplementation for preventing morbidity and mortality in children from 6 months to 5 years of age

Comparison: I Vitamin A versus Control

Outcome: 23 Hospitalisation due to Diarrhoea at Longest Follow-up

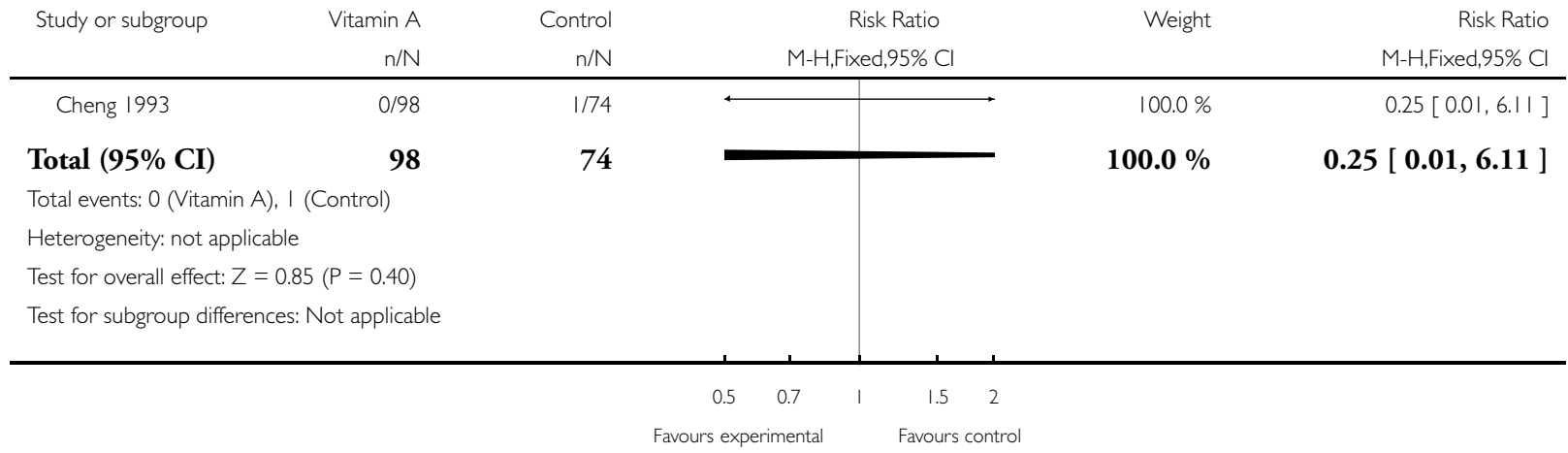




\section{Analysis I.24. Comparison I Vitamin A versus Control, Outcome 24 Hospitalisation due to Lower Respiratory Tract Infection at Longest Follow-up.}

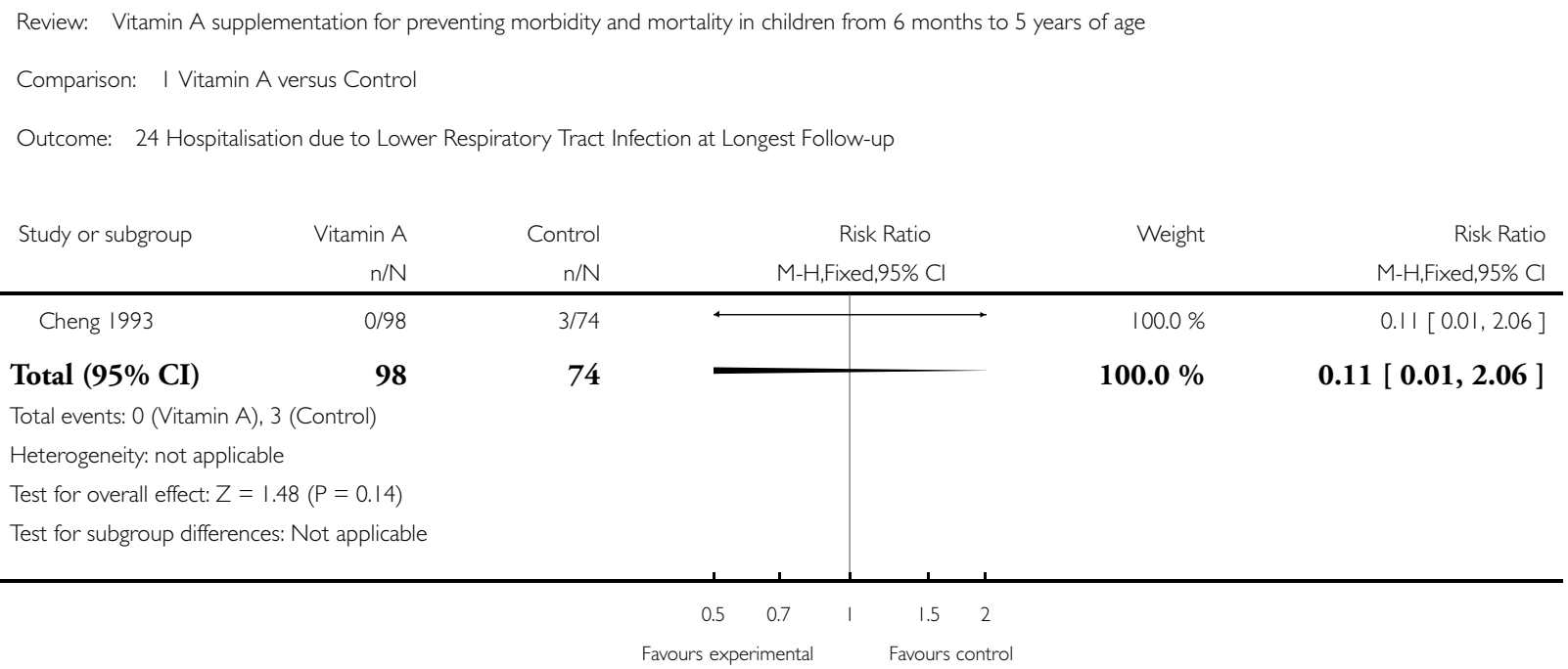

Analysis I.25. Comparison I Vitamin A versus Control, Outcome 25 Side effect - Bulging Fontanelle.

Review: Vitamin A supplementation for preventing morbidity and mortality in children from 6 months to 5 years of age

Comparison: I Vitamin A versus Control

Outcome: 25 Side effect - Bulging Fontanelle

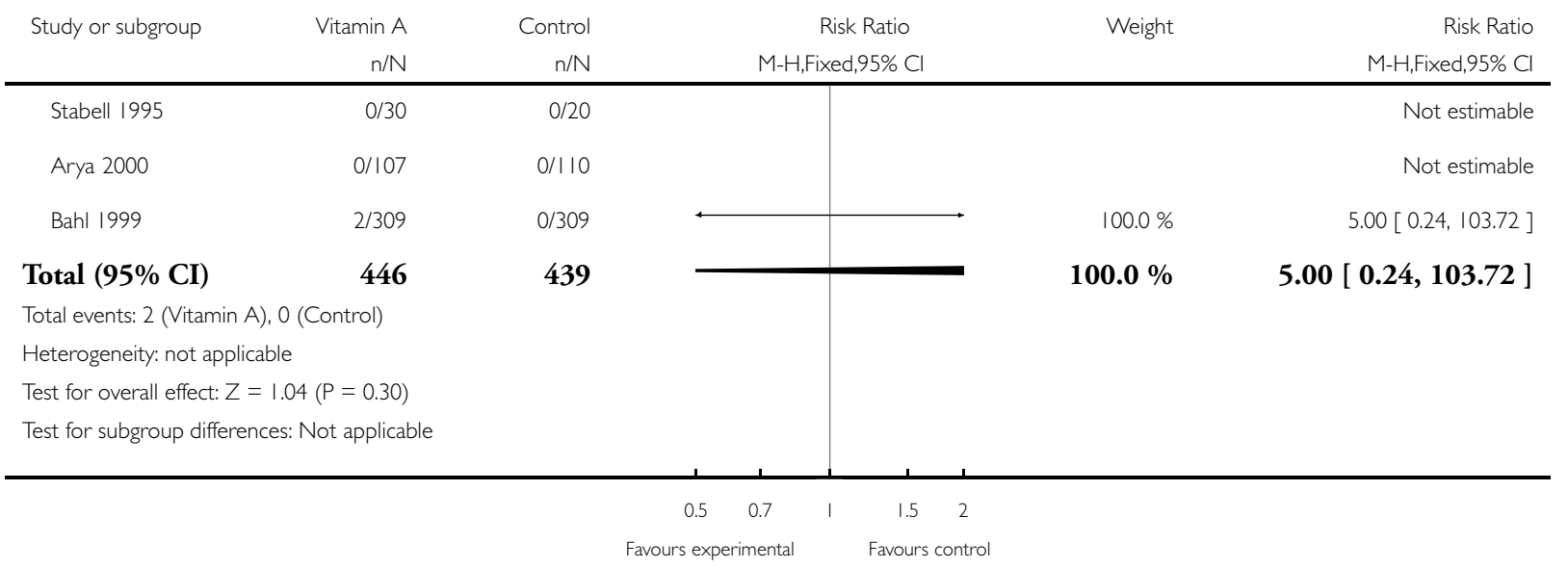

Vitamin A supplementation for preventing morbidity and mortality in children from 6 months to 5 years of age (Review)

Copyright @ 201 I The Cochrane Collaboration. Published by John Wiley \& Sons, Ltd. 


\section{Analysis I.26. Comparison I Vitamin A versus Control, Outcome 26 Side effect - Vomiting.}

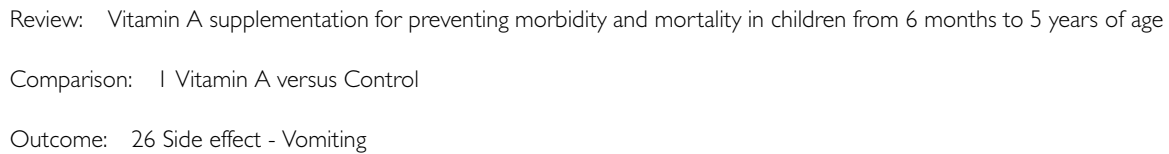

\begin{tabular}{cccc|ccc} 
& $\mathrm{n} / \mathrm{N}$ & $\mathrm{n} / \mathrm{N}$ & $\mathrm{M}-\mathrm{H}$, Fixed,95\% Cl & $\mathrm{M}-\mathrm{H}, \mathrm{Fixed}, 95 \% \mathrm{Cl}$ \\
\hline Sinha 1976 & $6 / 153$ & $0 / 153$ & & & $1.6 \%$ & $13.00[0.74,228.77]$
\end{tabular}

Arya $2000 \quad 13 / 107$

Florentino $1990 \quad 102 / 1635 \quad 18 / 836$

Total $(95 \% \mathrm{CI}) \quad 1895$

Total events: I2I (Vitamin A), 26 (Control)

\section{ADDITIONAL TABLES}

Table 1. Sensitivity and subgroup analyses

\begin{tabular}{|c|c|c|c|c|c|}
\hline $\begin{array}{l}\text { Outcome or Sub- } \\
\text { group }\end{array}$ & Studies & Heterogeneity & Statistical Method & Effect Estimate & $\begin{array}{l}\text { Test for Subgroup dif- } \\
\text { ference } \\
\text { (p-value) }\end{array}$ \\
\hline $\begin{array}{l}\text { Mor- } \\
\text { tality (all-cause) at } \\
\text { Longest Follow-up } \\
\text { (Sensitivity analysis } \\
\text { using random ef- } \\
\text { fects model) }\end{array}$ & 17 & $\begin{array}{l}\text { Heterogeneity: } \mathrm{Tau}^{2}= \\
0.04 ; \mathrm{Chi}^{2}=29.10, \mathrm{df} \\
=15(\mathrm{P}=0.02) ; \mathrm{I}^{2}= \\
48 \%\end{array}$ & $\begin{array}{l}\text { Risk Ratio (IV, Ran- } \\
\text { dom, 95\% CI) }\end{array}$ & $0.71[0.61,0.84]$ & NA \\
\hline
\end{tabular}


Table 1. Sensitivity and subgroup analyses (Continued)

\begin{tabular}{|c|c|c|c|c|c|}
\hline $\begin{array}{l}\text { Mor- } \\
\text { tality (all-cause) at } \\
\text { Longest Follow-up } \\
\text { (Sensitivity Analysis } \\
\text { assumes NO im- } \\
\text { pact of clustering } \\
\text { for studies with un- } \\
\text { known ICC) }\end{array}$ & 17 & $\begin{array}{l}\text { Heterogeneity: } \mathrm{Chi}^{2}= \\
\text { 48.83, df }=15(\mathrm{P}<0 . \\
0001) ; \mathrm{I}^{2}=69 \%\end{array}$ & $\begin{array}{l}\text { Risk Ratio (IV, Fixed, } \\
95 \% \text { CI) }\end{array}$ & $0.81[0.75,0.89]$ & NA \\
\hline $\begin{array}{l}\text { Mor- } \\
\text { tality (all-cause) at } \\
\text { Longest Follow-up } \\
\text { (Sensitivity Analysis } \\
\text { assumes HIGH im- } \\
\text { pact of clustering } \\
\text { for studies with un- } \\
\text { known ICC) }\end{array}$ & 17 & $\begin{array}{l}\text { Heterogeneity: } \text { Chi }^{2}= \\
25.67, \mathrm{df}=15(\mathrm{P}=0 . \\
04) ; \mathrm{I}^{2}=42 \%\end{array}$ & $\begin{array}{l}\text { Risk Ratio (IV, Fixed, } \\
95 \% \text { CI) }\end{array}$ & $0.75[0.68,0.83])$ & NA \\
\hline $\begin{array}{l}\text { Mortality (all- } \\
\text { cause) at Longest } \\
\text { Follow-up (by Na- } \\
\text { tional Child Mor- } \\
\text { tality Rate): High (> } \\
40 / 1000)\end{array}$ & 15 & $\begin{array}{l}\text { Heterogeneity: } \mathrm{Chi}^{2}= \\
29.02, \mathrm{df}=14(\mathrm{P}=0 . \\
01) ; \mathrm{I}^{2}=52 \%\end{array}$ & $\begin{array}{l}\text { Risk Ratio (IV, Fixed, } \\
95 \% \text { CI) }\end{array}$ & $0.76[0.69,0.83]$ & 0.78 \\
\hline $\begin{array}{l}\text { Mortality (all- } \\
\text { cause) at Longest } \\
\text { Follow-up (by Na- } \\
\text { tional Child Mor- } \\
\text { tality Rate): Low } \\
(<40 / 1000)\end{array}$ & 2 & $\begin{array}{l}\text { Heterogeneity: Not ap- } \\
\text { plicable }\end{array}$ & $\begin{array}{l}\text { Risk Ratio (IV, Fixed, } \\
95 \% \text { CI) }\end{array}$ & $1.00[0.14,7.08]$ & \\
\hline $\begin{array}{l}\text { Mor- } \\
\text { tality (all-cause) at } \\
\text { Longest Follow-up } \\
\text { (by Region): Asia }\end{array}$ & 11 & $\begin{array}{l}\text { Heterogeneity: } \mathrm{Chi}^{2}= \\
15.00, \mathrm{df}=9(\mathrm{P}=0.09) \\
; \mathrm{I}^{2}=40 \%\end{array}$ & $\begin{array}{l}\text { Risk Ratio (IV, Fixed, } \\
95 \% \text { CI) }\end{array}$ & $0.69[0.61,0.79]$ & 0.12 \\
\hline $\begin{array}{l}\text { Mor- } \\
\text { tality (all-cause) at } \\
\text { Longest Follow-up } \\
\text { (by Region): Africa }\end{array}$ & 5 & $\begin{array}{l}\text { Heterogeneity: } \mathrm{Chi}^{2}= \\
9.81, \mathrm{df}=4(\mathrm{P}=0.04) \\
; \mathrm{I}^{2}=59 \%\end{array}$ & $\begin{array}{l}\text { Risk Ratio (IV, Fixed, } \\
95 \% \text { CI) }\end{array}$ & $0.85[0.73,0.98]$ & \\
\hline $\begin{array}{l}\text { Mor- } \\
\text { tality (all-cause) at } \\
\text { Longest Follow-up } \\
\text { (by Region): Latin } \\
\text { America }\end{array}$ & 1 & $\begin{array}{l}\text { Heterogeneity: Not } \\
\text { applicable }\end{array}$ & $\begin{array}{l}\text { Risk Ratio (IV, Fixed, } \\
95 \% \text { CI) }\end{array}$ & $1.00[0.14,7.08]$ & \\
\hline
\end{tabular}


Table 1. Sensitivity and subgroup analyses (Continued)

\begin{tabular}{|c|c|c|c|c|c|}
\hline $\begin{array}{l}\text { Mortal- } \\
\text { ity (all-cause), out- } \\
\text { comes }<1 \text { year since } \\
\text { randomisation }\end{array}$ & 13 & $\begin{array}{l}\text { Heterogeneity: } \mathrm{Chi}^{2}= \\
33.85, \mathrm{df}=11(\mathrm{P}=0 . \\
0004) ; \mathrm{I}^{2}=67 \%\end{array}$ & $\begin{array}{l}\text { Risk Ratio (IV, Fixed, } \\
95 \% \text { CI) }\end{array}$ & $0.82[0.74,0.91]$ & NA \\
\hline $\begin{array}{l}\text { Mortality due to Di- } \\
\text { arrhoea, outcomes < } \\
1 \text { year since ran- } \\
\text { domisation }\end{array}$ & 5 & $\begin{array}{l}\text { Heterogeneity: } \mathrm{Chi}^{2}= \\
5.14, \mathrm{df}=4(\mathrm{P}=0.27) \\
; \mathrm{I}^{2}=22 \%\end{array}$ & $\begin{array}{l}\text { Risk Ratio (IV, Fixed, } \\
95 \% \text { CI) }\end{array}$ & $0.75[0.59,0.96]$ & NA \\
\hline $\begin{array}{l}\text { Mortality due to } \\
\text { LRTI, outcomes }<1 \\
\text { year since randomi- } \\
\text { sation }\end{array}$ & 5 & $\begin{array}{l}\text { Heterogeneity: } \mathrm{Chi}^{2}= \\
5.70, \mathrm{df}=6(\mathrm{P}=0.46) \\
; \mathrm{I}^{2}=0 \%\end{array}$ & $\begin{array}{l}\text { Risk Ratio (IV, Fixed, } \\
95 \% \text { CI) }\end{array}$ & $0.71[0.41,1.21]$ & NA \\
\hline $\begin{array}{l}\text { Mortality due to } \\
\text { Measles, outcomes < } \\
1 \text { year since ran- } \\
\text { domisation }\end{array}$ & 4 & $\begin{array}{l}\text { Heterogeneity: } \mathrm{Chi}^{2}= \\
0.52, \mathrm{df}=3(\mathrm{P}=0.91) \\
; \mathrm{I}^{2}=0 \%\end{array}$ & $\begin{array}{l}\text { Risk Ratio (IV, Fixed, } \\
95 \% \text { CI) }\end{array}$ & $0.85[0.52,1.37]$ & NA \\
\hline $\begin{array}{l}\text { Mor- } \\
\text { tality due to Menin- } \\
\text { gitis, outcomes < } 1 \\
\text { year since randomi- } \\
\text { sation }\end{array}$ & 1 & $\begin{array}{l}\text { Heterogeneity: Not ap- } \\
\text { plicable }\end{array}$ & $\begin{array}{l}\text { Risk Ratio (IV, Fixed, } \\
95 \% \text { CI) }\end{array}$ & $5.79[0.22,153.24]$ & NA \\
\hline $\begin{array}{l}\text { Di- } \\
\text { arrhoea Incidence at } \\
\text { Longest Follow-up } \\
\text { (Sensitivity analysis } \\
\text { using random ef- } \\
\text { fects model) }\end{array}$ & 13 & $\begin{array}{l}\text { Heterogeneity: } \mathrm{Chi}^{2}= \\
218.62, \mathrm{df}=11 \quad(\mathrm{P}<0 . \\
00001) ; \mathrm{I}^{2}=95 \%\end{array}$ & $\begin{array}{l}\text { Risk Ratio (IV, Ran- } \\
\text { dom, 95\% CI) }\end{array}$ & $0.85[0.72,1.00]$ & NA \\
\hline $\begin{array}{l}\text { Diarrhoea Inci- } \\
\text { dence, outcomes }<1 \\
\text { year since randomi- } \\
\text { sation }\end{array}$ & 10 & $\begin{array}{l}\text { Heterogeneity: } \mathrm{Chi}^{2}= \\
\text { 49.93, df }=8 \quad(\mathrm{P}<0 . \\
00001) ; \mathrm{I}^{2}=84 \%\end{array}$ & $\begin{array}{l}\text { Risk Ratio (IV, Fixed, } \\
95 \% \text { CI) }\end{array}$ & $0.93[0.89,0.97]$ & NA \\
\hline $\begin{array}{l}\text { Lower Respiratory } \\
\text { Tract Infection Inci- } \\
\text { dence, outcomes }<1 \\
\text { year since randomi- } \\
\text { sation }\end{array}$ & 8 & $\begin{array}{l}\text { Heterogeneity: } \mathrm{Chi}^{2}= \\
4.47, \mathrm{df}=5(\mathrm{P}=0.48) \\
; \mathrm{I}^{2}=0 \%\end{array}$ & $\begin{array}{l}\text { Risk Ratio (IV, Fixed, } \\
95 \% \text { CI) }\end{array}$ & $0.99[0.78,1.26]$ & NA \\
\hline $\begin{array}{l}\text { Malaria Incidence, } \\
\text { outcomes 1+ year } \\
\text { since randomisation } \\
\text { (by Age) }\end{array}$ & 1 & $\begin{array}{l}\text { Heterogeneity: Not ap- } \\
\text { plicable }\end{array}$ & $\begin{array}{l}\text { Risk Ratio (M-H, } \\
\text { Fixed, 95\% CI) }\end{array}$ & $0.73[0.60,0.88]$ & NA \\
\hline
\end{tabular}


Table 1. Sensitivity and subgroup analyses (Continued)

\begin{tabular}{|c|c|c|c|c|c|}
\hline $\begin{array}{l}\text { Measles Incidence, } \\
\text { outcomes < } 1 \text { year } \\
\text { since randomisation }\end{array}$ & 5 & $\begin{array}{l}\text { Heterogeneity: } \mathrm{Chi}^{2}= \\
0.24, \mathrm{df}=4(\mathrm{P}=0.99) \\
; \mathrm{I}^{2}=0 \%\end{array}$ & $\begin{array}{l}\text { Risk Ratio (IV, Fixed, } \\
95 \% \text { CI) }\end{array}$ & $0.54[0.36,0.80]$ & NA \\
\hline $\begin{array}{l}\text { Bitot's Spots Inci- } \\
\text { dence, outcomes }<1 \\
\text { year since randomi- } \\
\text { sation }\end{array}$ & 1 & $\begin{array}{l}\text { Heterogeneity: Not ap- } \\
\text { plicable }\end{array}$ & $\begin{array}{l}\text { Risk Ratio (IV, Fixed, } \\
95 \% \text { CI) }\end{array}$ & $0.93[0.76,1.14]$ & NA \\
\hline $\begin{array}{l}\text { Bitot's Spots Preva- } \\
\text { lence, outcomes }<1 \\
\text { year since randomi- } \\
\text { sation }\end{array}$ & 3 & $\begin{array}{l}\text { Heterogeneity: } \mathrm{Chi}^{2}= \\
6.06, \mathrm{df}=2(\mathrm{P}=0.05) \\
; \mathrm{I}^{2}=67 \%\end{array}$ & $\begin{array}{l}\text { Risk Ratio (IV, Fixed, } \\
95 \% \text { CI) }\end{array}$ & $0.43[0.33,0.56]$ & NA \\
\hline $\begin{array}{l}\text { Night Blindness } \\
\text { Prevalence, out- } \\
\text { comes }<1 \text { year since } \\
\text { randomisation }\end{array}$ & 1 & $\begin{array}{l}\text { Heterogeneity: Not } \\
\text { applicable }\end{array}$ & $\begin{array}{l}\text { Risk Ratio (IV, Fixed, } \\
95 \% \text { CI) }\end{array}$ & $0.30[0.17,0.52]$ & NA \\
\hline $\begin{array}{l}\text { Xerophthalmia In- } \\
\text { cidence, outcomes < } \\
1 \text { year since ran- } \\
\text { domisation }\end{array}$ & 2 & $\begin{array}{l}\text { Heterogeneity: Not } \\
\text { applicable }\end{array}$ & $\begin{array}{l}\text { Risk Ratio (IV, Fixed, } \\
95 \% \text { CI) }\end{array}$ & $0.88[0.72,1.07]$ & NA \\
\hline $\begin{array}{l}\text { Vita- } \\
\text { min A Serum Level } \\
\text { at Longest Follow- } \\
\text { up (Sensitivity anal- } \\
\text { ysis using random } \\
\text { effects model) }\end{array}$ & 14 & $\begin{array}{l}\text { Heterogeneity: } \mathrm{Tau}^{2}= \\
0.22 ; \mathrm{Chi}^{2}=270.23, \mathrm{df} \\
=13(\mathrm{P}<0.000001) ; \mathrm{I}^{2} \\
=95 \%\end{array}$ & $\begin{array}{l}\text { Std. Mean Difference } \\
\text { (IV, Random, 95\% CI) }\end{array}$ & $0.53[0.27,0.79]$ & NA \\
\hline $\begin{array}{l}\text { Vitamin A Serum } \\
\text { Level, outcomes }<1 \\
\text { year since randomi- } \\
\text { sation }\end{array}$ & 11 & $\begin{array}{l}\text { Heterogeneity: } \mathrm{Chi}^{2}= \\
178.42 \text {, df } 10, \quad(\mathrm{P}<0 . \\
000001), \mathrm{I}^{2}=94 \%\end{array}$ & $\begin{array}{l}\text { Std. Mean Difference } \\
\text { (IV, Fixed, 95\% CI) }\end{array}$ & $0.45[0.37,0.53]$ & NA \\
\hline
\end{tabular}




\section{A P P E N D I C ES}

\section{Appendix I. Search strategies}

\section{MEDLINE (1950 to April Week 2 2010)}

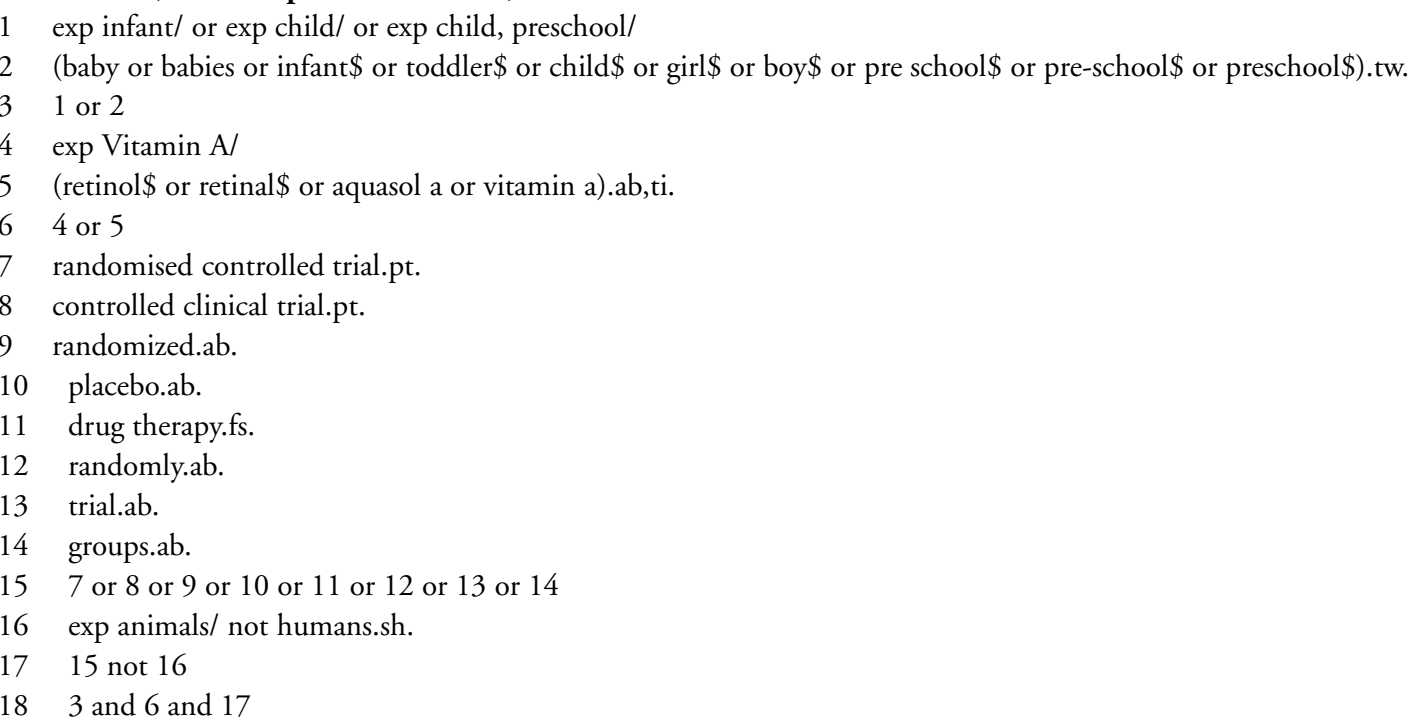

\section{EMBASE (1980 to 2010 Week 16)}

EMTREE index terms were used when possible. The UK Cochrane Centre's suggested combination of EMTREE and free text words were used to search for randomized-controlled trials.

1 exp infant/ or exp child/ or exp child, preschool/

(baby or babies or infant $\$$ or toddler $\$$ or child $\$$ or girl\$ or boy $\$$ or pre school $\$$ or pre-school $\$$ or preschool $\$$ ).tw.

$$
1 \text { or } 2
$$

$\exp$ Vitamin A/

(retinol\$ or retinal $\$$ or aquasol a or vitamin a).ab,ti.

\section{4 or 5}

exp crossover-procedure/ or exp double-blind procedure/ or exp randomized controlled trial/ or exp single-blind procedure/

8 (random $\$$ or factorial $\$$ or crossover $\$$ or cross over $\$$ or cross-over $\$$ or placebo $\$$ or (doubl\$ adj blind $\$$ ) or (singl $\$$ adj blind $\$$ ) or assign $\$$ or allocat $\$$ or volunteer\$).mp.

97 or 8

$10 \quad 3$ and 6 and 9

The Cochrane Central Register of Controlled Trials (CENTRAL) 27 April 2010

Vitamin A supplementation for preventing morbidity and mortality in children from 6 months to 5 years of age (Review) 
$\mathrm{MeSH}$ descriptor Child explode all trees

$\mathrm{MeSH}$ descriptor Infant explode all trees

$\mathrm{MeSH}$ descriptor Child, Preschool explode all trees

(baby or babies or infant* or toddler* or child* or (pre next school*) or preschool* or girl* or boy*):ti,ab,kw

(\#1 OR \#2 OR \#3 OR \#4)

$\mathrm{MeSH}$ descriptor Vitamin A explode all trees

retinol* or retinal\$ or "aquasol a" or "vitamin a"

(\#6 OR \#7)

(\#5 AND \#8)

Latino Americana e do Caribe em Ciências da Saúde (LILACS) 27 April 2010

Mh vitamin a or tw retinol\$ or tw aquasol\$ or tw retinal\$ [Words] AND [Tw baby or Tw babies or Tw child\$ or Tw infant\$ or Tw toddler $\$$ or Tw girl\$ or Tw boy $\$$ or Tw prescshool\$ or Tw pre-school\$ or Tw niño or Tw niños or Tw niña or Tw niñas or Tw bebé or Tw bebés or Tw preescolar or Tw prescolares [Words]

AND ((Pt randomized controlled trial OR Pt controlled clinical trial OR Mh randomized controlled trials OR Mh random allocation OR Mh double-blind method OR Mh single-blind method) AND NOT (Ct animal AND NOT (Ct human and Ct animal)) OR (Pt clinical trial OR Ex E05.318.760.535\$ OR (Tw clin\$ AND (Tw trial\$ OR Tw ensa\$ OR Tw estud\$ OR Tw experim\$ OR Tw investiga \$)) OR ((Tw singl\$ OR Tw simple\$ OR Tw doubl\$ OR Tw doble\$ OR Tw duplo\$ OR Tw trebl\$ OR Tw trip\$) AND (Tw blind\$ OR Tw cego\$ OR Tw ciego\$ OR Tw mask\$ OR Tw mascar\$)) OR Mh placebos OR Tw placebo\$ OR (Tw random\$ OR Tw randon\$ OR Tw casual\$ OR Tw acaso\$ OR Tw azar OR Tw aleator\$) OR Mh research design) AND NOT (Ct animal AND NOT (Ct human and Ct animal)) OR (Ct comparative study OR Ex E05.337\$ OR Mh follow-up studies OR Mh prospective studies OR Tw control\$ OR Tw prospectiv\$ OR Tw volunt\$ OR Tw volunteer\$) AND NOT (Ct animal AND NOT (Ct human and Ct animal)) ) [Words]

African Index Medicus 27 April 2010

1. retinol\$ or retinal $\$$ or aquasol a or vitamin a [Descriptor]

metaRegister of Controlled Trials 27 April 2010

(baby or babies or infant or child) and (vitamin a or aquasol or retinol or retinal)

\section{WHAT'S NEW}

Last assessed as up-to-date: 26 October 2010.

\begin{tabular}{l|ll}
\hline Date & Event & Description \\
\hline 7 December 2010 & Amended & Edited to correct typographical errors and improve readability \\
\hline
\end{tabular}

\section{CONTRIBUTIONSOFAUTHORS}

$\mathrm{AI}$ and EMW contributed to the background. EMW, KH and AI were primarily responsible for the methods. Margaret Anderson (from CDPLPG) developed the search strategy and $\mathrm{KH}$ conducted the literature search. AI, YY and $\mathrm{KH}$ reviewed citations for inclusion, disagreements were resolved through consultation with EMW. AI, KH, YY and EMW extracted data with three members from the Cochrane Editorial Unit (Toby Lasserson, Rachel Murphey, and Karla Soares-Weiser). KH and EMW entered outcome data into RevMan, analysed the data and wrote results. AI made the included studies and risk of bias tables. KH, EMW and AI contributed to writing the discussion. Toby Lasserson drafted the summary of findings table, which was agreed by all authors. ZB provided supervision and contributed to the writing and analyses.

Vitamin A supplementation for preventing morbidity and mortality in children from 6 months to 5 years of age (Review) 


\section{DECLARATIONSOF INTEREST}

None known.

\section{SOURCES OF SUPPORT}

\section{Internal sources}

- Aamer Imdad, Mohammad Yawar Yakoob and Zulfiqar A Bhutta are supported by Aga Khan University, Karachi, Pakistan.

- Kurt Herzer and Evan Mayo-Wilson are supported by the Centre for Evidence-Based Intervention, University of Oxford, UK.

\section{External sources}

- Funding for the review was provided by Department of Nutrition for Health and Development, World Health Organization, Switzerland.

\section{DIFFERENCESBETWEEN PROTOCOLANDREVIEW}

1) Sensitivity analyses are performed only for all-cause mortality, diarrhoea incidence and vitamin A serum levels.

2) Post-hoc analyses were performed for Imputed ICC and studies awaiting assessment.

3) Subgroup analysis based on baseline HIV status was not performed as none of the included studies gave a baseline status of study population on HIV and we excluded studies conducted on children with HIV.

4) Post-hoc, we included two studies in which participants were assigned using a quasi-random method.

\section{NDEX TERMS}

\section{Medical Subject Headings (MeSH)}

Cause of Death; Diarrhea [mortality]; Measles [mortality]; Meningitis [mortality]; Randomized Controlled Trials as Topic; Respiration Disorders [mortality]; Vitamin A [*administration \& dosage; adverse effects]; Vitamin A Deficiency [complications; *drug therapy; mortality]; Vitamins [*administration \& dosage; adverse effects]

\section{MeSH check words}

Child, Preschool; Humans; Infant 